\title{
SAP E PSICANÁLISE \\ NO CAMPO PSICOJURÍDICO: \\ de um amor exaltato ao dom do amor
}

Dissertação apresentada ao

Instituto de Psicologia da

Universidade de São Paulo como

parte dos requisitos para

obtenção do grau de Mestre em Psicologia.

Área de concentração:

Psicologia Clínica

Orientadora:

Profa. Dra Léia Priszkulnik

São Paulo

2011 
AUTORIZO A REPRODUÇÃO E DIVULGAÇÃO TOTAL OU PARCIAL DESTE TRABALHO, POR QUALQUER MEIO CONVENCIONAL OU ELETRÔNICO, PARA FINS DE ESTUDO E PESQUISA, DESDE QUE CITADAA FONTE.

Catalogação na publicação

Biblioteca Dante Moreira Leite

Instituto de Psicologia da Universidade de São Paulo

Brockhausen, Tamara.

SAP e psicanálise no campo psicojurídico: de um amor exaltado ao dom do amor / Tamara Brockhausen; orientadora Léia Priszkulnik. -- São Paulo, 2011.

$274 \mathrm{f}$.

Dissertação (Mestrado - Programa de Pós-Graduação em Psicologia. Area de Concentração: Psicologia Clínica) - Instituto de Psicologia da Universidade de São Paulo.

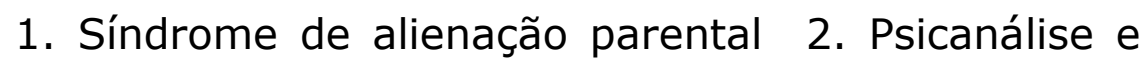
Direito 3. Alienação 4. Transferência psicoterapêutica 5. Psicologia forense I. Título. 
Nome: Brockhausen, Tamara

Título: SAP e Psicanálise no campo Psicojurídico: de um amor exaltado ao dom do amor

Dissertação apresentada ao Instituto de Psicologia da Universidade de São Paulo para obtenção do título de Mestre em Psicologia

Aprovado em:

Banca Examinadora:

Prof. Dr.

Instituição:

Assinatura

Prof. Dr.

Instituição:

Assinatura

Prof. Dr.

Instituição: Assinatura 
À minha mãe e professora, Sandra Dias, por transmitir o que há de mais elevado - a aposta no desejo, sempre.... 


\section{AGRADECIMENTOS}

A Léia Priszkulnik, minha orientadora, com quem pude contar sobretudo para o que considero tarefa das mais difíceis - limitar, recortar minhas ideias multiplicadas, palavras mil e angústias sem fim, para que pudessem se transformar simplesmente como ela ressignifica, em "apenas um trabalho".

Aos colegas de profissão, peritos que se dispuseram a uma discussão honesta a respeito das questões judiciais, ultrapassando a típica relação imaginária de oposição entre perito e assistente técnico, contribuindo dessa forma para a experiência real do meu trabalho, o qual tento resumir em forma de mestrado. Em especial, a Sidney Shine, perito e psicanalista, em quem pude encontrar esta primeira figura importante, que pôde se repetir muitas e muitas vezes em diferentes relações de trabalho.

À exímia advogada de família Dra. Sandra Regina Vilela, grande companheira na vida e na profissão, por permitir um diálogo tão aberto, pela honestidade intelectual e pelas trocas multidisciplinares que em muito fazem parte deste trabalho.

Aos Professores Dr. Christian Ingo Lenz Dunker e Dr. Francisco José Cahali, por servirem de inspiração pelo amor à pesquisa.

A William Bernet, meu correspondente internacional, que, tão generoso com seu tempo e saber, me abriu portas mundo afora.

A Elizio, testemunho de minha despedida da neurose freudiana - a impossibilidade de amar e trabalhar. Sua presença reúne as duas formas de libertação de uma só vez. Quem tornou possível que eu experimentasse passar pela vida e ver que a minha maior aposta deu certo - e que mesmo assim a "nossa aposta" continua... outras apostas virão...

Novamente a Elizio, pela retidão e pelo inconformismo com a violência moderna administrada. Pelo espírito revolucionário, por ter levado a cabo seu desejo de transformar as leis do país. Por lutar por um convívio mais equilibrado entre as crianças e seus pais e por desnudar a silenciosa violência infantil do pós-divórcio. A nova Lei brasileira contribuiu direta e indiretamente a este trabalho. Não menos, nossas discussões fervorosas, conversas de horas noite adentro, leitura de textos, questões políticas e técnicas, experiências, convicções, dúvidas e muita autoanálise. 
Aos meus irmãos, Samantha e Igor, pelo que comportam de mais familiar que possa haver entre irmãos. Em especial a Samantha pela incansável doação e ajuda na língua inglesa.

A minha mãe, resumo minha atual estadia: o respeito pelo sacrifício em se ter um filho e nele tudo apostar, a gratidão pelo que foi dado e igualmente pelo que foi negado.

Igualmente ao meu pai, Dieter, por sua presença inconfundível.

À Fundação de Amparo à Pesquisa do Estado de São Paulo, pela concessão da bolsa de mestrado e pelo apoio financeiro à realização desta pesquisa. 


\section{RESUMO}

Brockhausen, T. (2011). SAP e Psicanálise no campo Psicojurídico: de um amor exaltado ao dom do amor. Dissertação de Mestrado, Instituto de Psicologia, Universidade de São Paulo, São Paulo.

Este trabalho pretende oferecer uma análise crítica da Síndrome de Alienação Parental (SAP). Primeiramente visa apresentar o conceito de SAP, o modelo diagnóstico e interventivo tal como propostos por Richard Alan Gardner, psiquiatra forense americano. A análise de sua obra baseiase em uma leitura psicanalítica que permite ampliar a explicação da ocorrência da síndrome para além de uma descrição fenomenológica e objetiva tal como formalizada pelo seu criador. A definição clínica permite hipotetizar os termos genético-estruturais da SAP segundo um recorte psicanalítico a partir de Freud e Lacan. Parte-se da constituição do sujeito para explicar que a eficácia da SAP é possível a partir de um reforçamento da alienação fundamental induzido por um cuidador em uma criança que está na sua dependência. Realiza-se uma formalização mais precisa da síndrome a partir da proposição da SAP como uma montagem particular de transferência que se estabelece entre a criança e um cuidador, que desfaz ou minimiza os laços com o outro genitor. O fenômeno da transferência é decomposto em seus elementos formativos, a saber, identificação, sugestão, fantasia e idealização, de forma a permitir explicar a SAP como uma conjugação específica desses componentes que resulta na associação de uma posição subjetiva da criança à posição do genitor programador. Desta leitura são extraídas consequências à práxis no campo Psicojurídico, as quais permitem discutir algumas questões relativas ao tratamento e à sua regulação no interior do dispositivo jurídico. Embora a psicanálise critique modelos psicopatológicos e nosográficos, algumas linhas mestras iluminadas na SAP de Gardner trazem contribuições inovadoras frente aos sintomas da família moderna, permitindo resgatar a eficácia de um sistema disciplinar jurídico ligado ao processo civilizatório com efeitos terapêuticos e viabilizando a configuração familiar das duas linhagens como núcleo referente e formador da criança.

Palavras-chave: Síndrome de Alienação Parental (SAP). Direito. Psicanálise. Alienação. Transferência. 


\begin{abstract}
Brockhausen, T. (2011). PAS and Psychoanalysis in the psycholegal field: from exalted love to gift one. Masters Dissertation, Psychology Institute, University of São Paulo, São Paulo.
\end{abstract}

The aim of this study is to offer a critical analysis of the Parental Alienation Syndrome (PAS). First it intends to introduce the concept of PAS, the diagnostic and interventional model as proposed by Richard Alan Gardner, American forensic psychiatrist. The analysis of his work relies on a psychoanalytic reading that allows to extend the explanation of the occurrence of the syndrome in addition to a phenomenological and objective description as formalized by its creator. The clinical definition makes possible to hypothesize genetic-structural terms of PAS through a psychoanalytic view from Freud and Lacan. It starts with the constitution of the subject to explain that the effectiveness of PAS is possible from a reinforcement of the fundamental alienation stimulated by a caregiver in a child who is in their dependence. It is carried out a more precise formalization of the syndrome from the proposition of the PAS as a particular transference assembly that is established between the child and a caregiver that undoes or minimizes the ties with the other parent. The phenomenon of transference is decomposed into its formative elements, namely, identification, suggestion, fantasy and idealization, in order to explain the PAS like a specific combination of these components which results in the association of a child's subjective position to the position of the programming parent. Consequences of this reading are taken to the practice in psycholegal field, which enable to discuss some issues related to treatment and its regulation within the legal provision. Although psychoanalysis criticizes psychopathological and nosographic models, some guidelines enlightened in Gardner'PAS bring forward innovative contributions to the symptoms of the modern family, enabling to rescue the effectiveness of a legal disciplinary system linked to the civilizing process with therapeutic effects and allowing the family configuration of the two lineages as referent and forming core of the child.

Keywords: Parental Alienation Syndrome (PAS). Law. Psychoanalysis. Alienation. Transference. 


\section{TRAJETÓRIA}

Em meio ao dever que toca minhas atribuições - tratar da família que passa por conflitos de alta litigância - era necessário ir além da minha função. Tomada muitas vezes por angústia, fiquei inerte, perplexa, paralisada junto a vidas devastadas. Vidas impotentes. Mortes inventadas. O disco riscou. A voz é sempre a mesma. Atordoa. Como fazer a diferença? Tenho voz? Quão conflituoso era, como psicanalista, me ver misturada ali, onde o dever me chamava. Evidentemente sabia que não podia salvar, embora às vezes achasse que sim. Ser espectadora, puro olho a olhar, não. Apenas tinha a clareza de que não podia abandonar a causa, desde onde escrevo aqui.

A assertiva de que pessoas que procuram o judiciário são incapazes para tomar as rédeas de sua vida necessitando do Estado para regular seus conflitos, me parecia uma meia verdade Por ser meia a verdade, continuei procurando algo mais. Assim, o fio foi puxado... muito longo, não acabava nunca. Entre nós e emendas, achei crianças. Crianças lindas. Sujeitos devastados. Crianças invisíveis. Abandonadas não apenas por pais gozosos, pais enlouquecidos, pais?, mas pior, por todos os olhos a olhar. Entre olhos mil estaria eu ali? Violência a céu aberto. Pleno sol do meio-dia. Ninguém vê? O sol cega. O acerto, uma exceção.

Mas como a abelha que vai de flor em flor, de miudezas se faz um jardim. Crianças invisíveis por algumas vezes ganharam cores. Nessa pequena diferença, o trabalho foi possível. Tento traduzir em palavras olhares e vozes esquecidos e depois resgatados. Portas são abertas. Crianças ressurgem.

A família que passa por conflitos de alta litigância, devido a situações extremas de violência de todos os tipos, dilacera crianças, provoca angústia em todos os profissionais que se aproximam. As respostas mais frequentes: omissão, paralisia, actings, intervenções precipitadas, condenações injustas... 
A ética psicanalítica abre uma perspectiva - não há criança sozinha. Não se pode salvá-la. Ela nasce de um desejo entre um homem e uma mulher de onde surge a parentalidade. Não há criança separada de seus pais desde onde deve ser feito seu resgate. Pais vítimas, pais algozes. Regular a invasão dos gozos irreconciliáveis, restituir a responsabilidade pela posição de sujeito é um desafio que não deve deixar de tocar aquele profissional que se lança num dever tão capital. Se famílias se perdem em meio à cortina de fumaça lançada pelo ódio no pós-divórcio, profissionais são chamados a responder desde esse lugar, o qual deve ser recusado embora não sem entrave pessoal dos mais exaustantes. Do resgate do lugar do profissional ao resgate da família. Duas faces da mesma moeda. 


\title{
CAPÍTULO1
}

1. A SÍNDROME DE ALIENAÇÃO PARENTAL (SAP) $\ldots \ldots \ldots \ldots \ldots \ldots \ldots \ldots$

1.1 CONTEXTO HISTÓRICO........................................................15

1.2 DEFINIÇÃO..........................................................................16

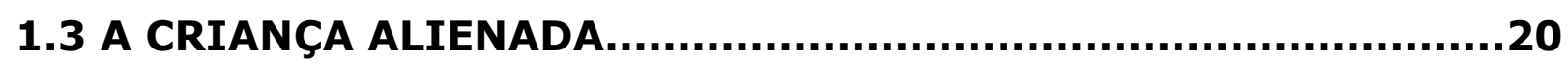

1.3.1 Manifestações clínicas na criança alienada............................20

1.3.2 Grau da Síndrome..................................................... 30

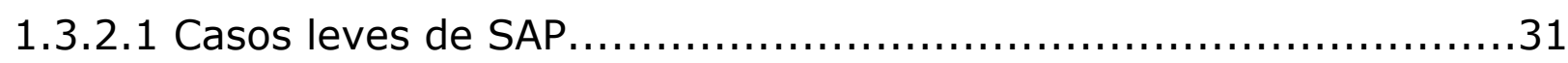

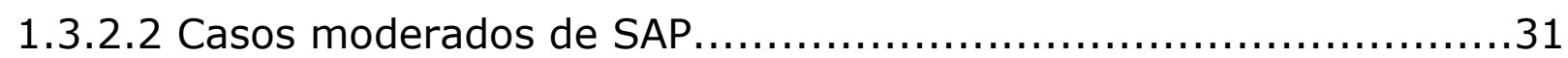

1.3.2.3 Casos severos de SAP.............................................. 32

1.3.3 Psicodinâmica da criança alienada.....................................32

1.4. O GENITOR ALIENADOR........................................................34

1.4.1 Manisfestações clínicas do genitor alienador............................42

1.4.2 Psicodinâmica do genitor alienador...................................44

1.50 GENITOR ALIENADO......................................................44

1.5.1 Psicodinâmica do genitor alienado......................................46

1.6 PROPOSTA INTERVENTIVA.....................................................46

1.6.1 Equipe de saúde mental............................................ 51

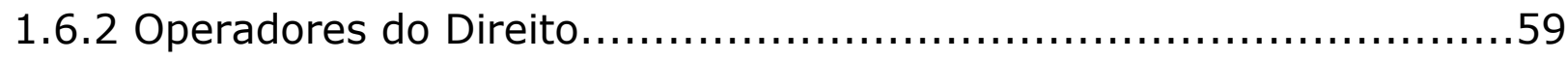

\section{CAPÍtULO 2}

2. ALIENAÇÃo PARENTAL NO DIREITO BRASILEIRO....................89

\author{
CAPÍTULO 3
}

3. FALSAS ALEGAÇÕES DE ABUSO SEXUAL. 


\section{CAPÍTULO 4}

4. SOBRE A ARTICULAÇÃO DA SAP À PSICANÁLISE...................108

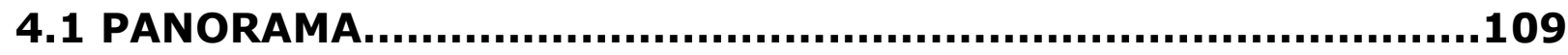

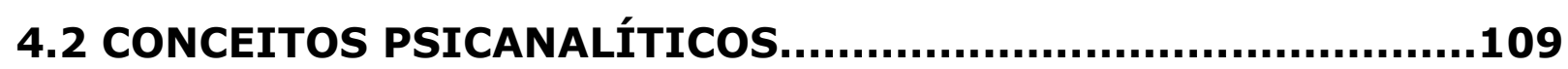

4.2.1 A criança, o sujeito, a infância e o infantil.............................109

4.2.2 A família, um dos nomes do Outro.....................................120

4.3 GÊNESE E ESTRUTURA DA SAP ................................. 126

4.3.1 Alienação fundamental e alienação na SAP.............................126

4.3.2 A SAP como um tipo de transferência...................................144

4.3.2.1 Articulação da sugestão na SAP....................................152

4.3.2.2 Articulação da fantasia, identificação e transferência na SAP.......181

\section{CAPÍtULO 5}

5. (DES)ALIENANDO - UMA SEPARAÇÃO NECESSÁRIA.................197

5.1 O VALOR DA SAP NA QUESTÃO DIAGNÓSTICA.........................197

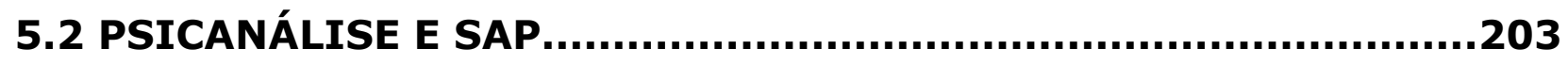

5.3 A SAP COMO SUBPRODUTO DA CULTURA...............................213

5.3.1 Alienação no sistema judiciário..........................................213

5.3 .2 Alienação nas escolas.............................................. 231

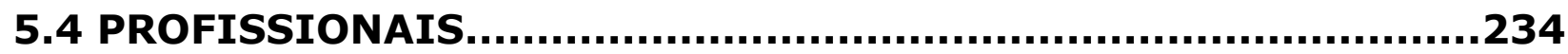

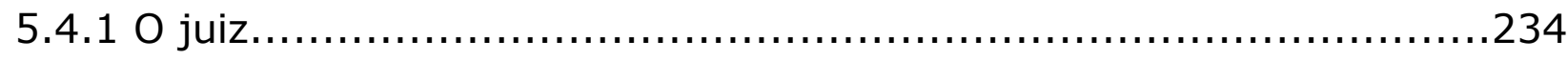

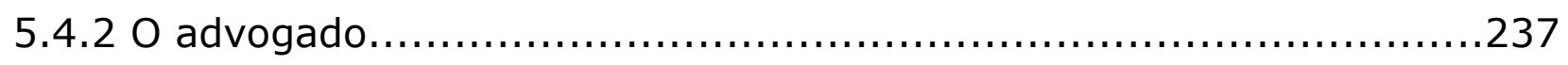

5.4 .3 O psicólogo: perito, terapeuta e avaliador...........................238

5.5 DIAGNÓSTICO DIFERENCIAL.................................................240

5.6. EM DIREÇÃO A NOVOS HORIZONTES...................................250

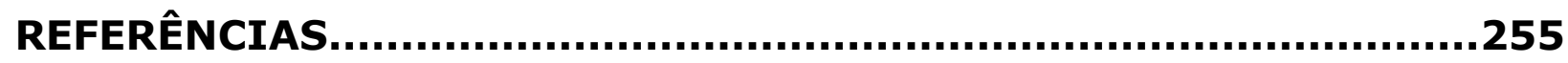

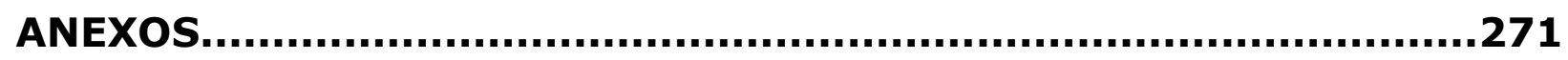




\section{INTRODUÇÃO}

Este trabalho pretende oferecer uma análise crítica da Síndrome de Alienação Parental (SAP), expressão cunhada pelo psiquiatra forense Richard Alan Gardner. Para tal, baseia-se numa leitura psicanalítica da qual serão extraídas implicações ao trabalho dos operadores do direito e uma política de intervenção no campo Psicojurídico.

No atual momento social brasileiro, ressalta-se a importância da análise do termo Síndrome de Alienação Parental dado que a recente Lei no 12.318, de 26 de outubro de 2010, que dispõe sobre Atos de Alienação Parental (ANEXO A), baseia-se, ainda que parcialmente, no termo cunhado por Gardner.

Esta nova Lei, que dentre outras questões pretende, em primeira instância, regular de forma mais eficiente o convívio dos filhos com os pais após a separação, passa a versar diretamente sobre o destino de famílias, os valores culturais e sociais, bem como sobre a práxis profissional Psicojurídica no Brasil.

Apesar de a Lei em questão ter buscado inspiração no termo Síndrome de Alienação Parental, não deve ser sobreposta ou tomada como equivalente ao conceito original do autor. Trata-se de discutir dois conceitos diferentes, a alienação de Gardner e a da Lei brasileira, para evitar que imprecisões e distorções no campo jurídico reflitam numa prática tão capital.

Entretanto, a Lei revela muitas similaridades com as observações trazidas por Gardner sobre a SAP. Nesse sentido, torna-se imperioso o retorno às origens gardnerianas para análise e esclarecimento dos pontos de aproximação e afastamento entre a Lei brasileira e a teoria do psiquiatra norte-americano. A importância de precisar os diferentes termos para sua utilização na prática profissional dos vários atores que lidam com estes tipos de casos deve-se ao fato de a Lei definir em termos jurídicos uma problemática originada na área psiquiátrico-psicológica. 
Devido à novidade do tema, a revisão bibliográfica da literatura brasileira carece de pesquisas com reflexões mais profundas, tanto na área Psicojurídica quanto na do direito. Tal constatação, somada à recente aprovação da lei, aumenta a necessidade de uma produção rigorosa sobre o assunto. Os textos na área Psicojurídica apresentam definições básicas sobre o tema, porém muitas vezes há confusões entre os nomes - alienação parental, atos de alienação parental e síndrome de alienação parental -, situação que exige precisão, propriedade considerada por Gardner como fundamental à correta intervenção. Há também poucas discussões mais técnicas no campo da SAP com relação à avaliação e diagnóstico, ao tratamento, aos efeitos nas crianças, sobre a delicada atuação profissional, sobre releituras que tragam novas abordagens, entre outros. Tampouco se encontram articulações da questão-problema à psicanálise.

No exterior, os países de língua inglesa apresentam maior produção sobre o tema. Nos Estados Unidos da América, encontra-se uma vasta publicação em diversas áreas (Medicina, Psicologia e Direito), desde artigos e pesquisas científicas, a periódicos, livros, entre outros. Países como Inglaterra, Canadá, Austrália, Alemanha, França, Suíça, Espanha e Argentina também apresentam publicações relevantes. Apesar de Gardner ter publicado mais de 40 títulos, inexistem quaisquer traduções para a língua portuguesa. Por essa razão, optou-se por apresentar neste trabalho a teoria de seu livro-base de forma mais extensa, levando ainda em consideração as necessárias discussões posteriores, que serão apresentadas. Apenas um de seus trabalhos foi publicado atualmente em uma coletânea - "The International Handbook of Parental Alienation Syndrome" (Gardner, Sauber \& Lorandos, 2006). Seus estudos deram lugar à produção de sucessores que remodelaram alguns pontos de sua teoria muitas vezes propondo o termo AP no lugar de SAP.

Semelhanças do cenário norte-americano jurídico e social das décadas de 1970 e 1980 podem ser contrapostas à realidade brasileira. Gardner refere que o aumento vertiginoso de casos de SAP nos EUA liga-se a mudanças da doutrina legal sobre a questão da guarda. No Brasil atual, de 
acordo com Silva (1999), constata-se maior vinculação, proximidade e cuidados do pai moderno com os filhos. A autora refere-se a esta nova paternidade na qualidade de "pai ativo". Essas transformações na família e no campo social, aos poucos, têm sido refletidas na cultura judiciária. O pai, antes distante e provedor, por estar mais próximo do cotidiano dos filhos, busca no pós-divórcio a legitimação de seu papel por meio do judiciário. Já é possível observar instrumentos jurídicos que regulem mais eficazmente a isonomia do Poder Familiar entre os gêneros no pós-divórcio, caso da Lei de alienação parental e de uma lei anterior a esta, a Lei de guarda compartilhada, aprovada em 2008.

Atualmente, os genitores do sexo masculino conseguem visitas ampliadas e deixam de lado o papel de "pai de final de semana". Algumas vezes conseguem até mesmo a guarda de seus filhos em situações antes não vislumbradas pela jurisprudência nacional. Essa maior proximidade paterna da prole desloca o lugar mítico e sagrado da mãe como referência central no cuidado infantil. Talvez, as transformações da família brasileira coincidam ao que foi descrito por Gardner na década de 1970 e 19 nos EUA. Segundo o autor, mudanças nos papéis parentais permitem explicar que a busca dos pais pela igualdade no exercício de sua função resultou no aumento vertiginoso dos litígios de visita e guarda, disparando uma verdadeira guerra entre os gêneros. As mães por sua vez, na ameaça do primado matriarcal, passaram produzir a SAP alinhando seus filhos na batalha judicial.

Simultaneamente, os operadores do direito no Brasil referem um aumento na frequência da SAP e das falsas alegações de abuso sexual, provavelmente originado a partir de mudanças sociais, legislativas e da cultura judiciária. Dessa forma, a SAP pode ser compreendida dentro de uma fase de transposição dos novos paradigmas da família brasileira.

O momento atual define-se pela virada de valores culturais, marcando embates de valores velhos e novos que não são desprovidos de um sofrimento acentuado nas famílias. O também turbulento momento 
sociocultural e jurídico ressalta a importância da discussão do tema, da produção de conhecimento e dos questionamentos das práticas.

Deve-se também considerar a importância da discussão do assunto devido ao amplo reflexo em áreas além do Direito de Família. Observa-se o impacto do assunto nas instituições que são chamadas a reportar-se quanto às famílias e crianças: escolas, hospitais, conselhos tutelares, delegacias, instituições para tratamento psicológico, entre outros. Muitas vezes esses profissionais são chamados a reportar-se diante das alegações de maustratos, abusos físicos e sexuais, negligência, abandono infantil e também das falsas alegações. O impacto também se dará no Direito Criminal em relação às alegações contra a criança e até mesmo alegações de violência contra a mulher, que podem ter origem falsa.

O tema central do trabalho levanta mais uma questão - a violência psicológica, ponto ainda pouco explorado e que recebe destaque diante desse novo enquadramento legislativo. O surgimento da Lei ressalta a invisibilidade do problema e ajuda a desmistificar a crença de que tais casos são menos graves do que outras formas de violência infantil. Nesse sentido, o tema vem contribuir para novos questionamentos e horizontes sobre a prática profissional.

O impacto da nova Lei aponta para a necessidade de ampliar os estudos que envolvem este tema espinhoso, para a reformulação das práticas profissionais adaptadas ao contexto da nova realidade, para a necessidade de melhoria na capacitação dos profissionais envolvidos, e de pensar-se globalmente nessa problemática com, por exemplo, a criação de programas de tratamento, prevenção, acompanhamento e de programas sociais, uma vez que a realidade é sempre mais ampla do que aquela apresentada nos tribunais.

A Lei ilumina outro tema em evidência: as falsas acusações, muitas vezes ligadas à SAP e desconsideradas até então, produzem intervenções equivocadas que geram danos secundários às famílias. Quanto à produção bibliográfica sobre o assunto, ainda existem poucos estudos. No Brasil, a prática profissional frequentemente não encontra apoio em técnicas para 
detectar as falsas acusações, não raro mostrando-se atrelada a antigas crenças do tipo "a criança não mente que foi abusada" ou então "não existem falsas alegações", mitos que não encontram uma sustentação científica, apesar de o abuso sexual infantil ser muito recorrente segundo a literatura especializada.

Frente à necessidade de novas articulações sobre o tema, que permitam ir além do modelo proposto por Gardner e ainda assim dialogar com a prática jurídica brasileira, a SAP será apresentada a partir de uma explicação psicanalítica que permita contribuir com o norte de uma política para sua regulação no interior do dispositivo Psicojurídico.

No primeiro capítulo será apresentada a definição da SAP, sua abordagem e intervenção segundo Gardner. No segundo capítulo será abordado o tema da alienação parental no Brasil, isto é, as produções acadêmicas, decisões judiciais, atuação profissional e comentários sobre a Lei. No terceiro capítulo, nestes mesmos termos, serão retomadas as falsas alegações de abuso sexual infantil originadas a partir da SAP.

Parte-se depois, no quarto capítulo para uma leitura psicanalítica a respeito da eficácia da SAP pela explicação dos conceitos de alienação e de constituição do sujeito em Lacan. Dessa forma pretende-se compreender a diferença entre uma alienação fundamental e constitutiva e um reforçamento desse processo na criança gerado a partir de um mecanismo artificial e forçoso, isto é, a programação do genitor alienador.

O conceito de alienação em psicanálise será enriquecido com a formalização da SAP como um tipo particular de transferência que se estabelece entre o genitor alienador e a criança com fins de excluir o outro genitor do lugar de referência da alteridade e do desejo para a criança. 0 conceito de transferência será decomposto em seus elementos formativos identificação, idealização, sugestão e fantasia -o que permite explicar a SAP na criança como uma montagem conjugada dos elementos formativos da transferência associada à oferta alienante do genitor, isto é, a uma posição subjetiva que visa elidir a falta instaurada pela separação conjugal, alocando 
para isso a criança como objeto de posse para recuperação de gozo e elidir o outro genitor da vida da criança.

$\mathrm{Na}$ conclusão, isto é, no capítulo 5, retoma-se o valor da SAP na questão diagnóstica. Dessa forma, ao isolar a posição subjetiva da criança em relação à posição do genitor alienador permite-se ir além de diagnóstico dado pelo conjunto de sinais e sintomas tal como preconiza a psiquiatria moderna. Tal proposição permite ir além das consequências da SAP na criança apontadas por Gardner como uma perda de laço afetivo e produção de sintomas na criança. A incidência da SAP, segundo o proposto neste trabalho, permite associá-la a uma superalienação do sujeito no campo do desejo e a uma fixação num gozo anômalo que prejudica o curso de separação do Outro parental, operação fundamental ao entendimento do que é patológico em psicanálise.

A partir do entendimento da SAP como alocação da criança como objeto de recuperação de gozo de um genitor engajado num projeto vingativo após a separação, é possível supor efeitos de alienação no porvir do sujeito desde onde é preciso sugerir uma política para a intervenção jurídica na SAP. Busca-se dessa forma orientar que a práxis jurídica e terapêutica não seja um meio de legitimação desse tipo de abuso infantil nem seja conivente com a ruptura de laços sociais que organizam o sujeito devolvendo a ele a possibilidade da referência à lei, ao desejo e à alteridade.

Que o direito, junto à psicanálise, possa oferecer a mais alta referência legal, aquela em que não se goza do poder coercitivo e autoritário, mas que permita às famílias, diante de seus gozos irreconciliáveis, uma trégua por meio da internalização de uma lei mais simbólica a qual os Operadores do Direito são chamados a representar. 


\section{A SÍNDROME DE ALIENAÇÃO PARENTAL (SAP)}

\subsection{CONTEXTO HISTÓRICO}

Em 1985, Gardner definiu a primeira vez a Síndrome de Alienação Parental (SAP) e a Alienação Parental (AP). O Psiquiatra entendeu que mudanças sociais e históricas nos Estados Unidos da América (EUA) estavam intimamente correlacionadas ao aumento abrupto da patologia que ele observara.

Em seu estudo, Gardner (1998, sempre em tradução nossa) sustenta que certamente a SAP existia nos EUA antes dele detectá-la a primeira vez, mas era algo relativamente incomum. Aponta que o gatilho foram mudanças, a partir de 1970, na forma de os tribunais decidirem a guarda dos filhos. Determinou também que a SAP correlaciona-se quase que exclusivamente à disputa de guarda e ao grau de litigância entre os pais no pós-divórcio.

No cenário social e jurídico anterior, a prática nos tribunais evidenciava que os genitores do sexo masculino tinham de provar sérias deficiências maternas para que fosse considerada a possibilidade de a guarda unilateral ser concedida ao pai. Existia mais firmemente a ideia de que as mães, por serem mulheres, eram intrinsecamente superiores aos homens na criação dos filhos. O princípio legal que regia a atribuição de guarda era chamado presunção da tenra idade, pelo qual as mães eram beneficiadas na atribuição de guarda. Posteriormente, no entanto, determinou-se nos EUA que esse critério era contrário à política pública, que se esforça para tratar igualmente os sexos.

De acordo com o autor, essencialmente duas mudanças desencadearam a intensificação da patologia: o advento do Superior Interesse da Criança na década de 1970, segundo o qual, os tribunais foram instruídos a desconsiderar o gênero nos processos de guarda e a determinar a guarda ao genitor que tivesse melhor capacidade parental; e, na década de 1980, a popularidade da Guarda Compartilhada. Essa 
nova validação trouxe desvantagens às mulheres e um aumento vertiginoso de disputas de guarda de crianças a pedido dos genitores do sexo masculino. Por consequência, as mães, que na maioria das vezes detinham a guarda dos filhos, passaram a recusar reconhecer essa mudança, programando seus filhos para se alinharem a seu lado na batalha judicial. Os filhos, por sua vez, diante de tal pressão, passaram a posicionar-se ao lado das mães, uma vez que era com quem geralmente conviviam, deferindo animosidade e recusando contato com o outro genitor.

\subsection{DEFINIÇÃo}

Gardner atuava como psiquiatra em avaliações no contexto de disputa de guarda havia mais de 25 anos quando introduziu o termo SAP em 1985. A Alienação Parental (AP), também cunhada pelo autor, suscitou uma série de equívocos e imprecisões no campo por serem ambas muito semelhantes.

Na prática, como avaliador, Gardner frequentemente se deparava com crianças que recusavam contato com um dos genitores, por terem sido por eles negligenciadas, maltratadas, violentadas física, sexual ou psicologicamente. Dessa forma, concluiu que a rejeição da criança ao genitor em questão era ocasionada por motivos reais ou genuínos.

No entanto, nos EUA, por volta dos anos 1980, o psiquiatra notou que algumas crianças no contexto do divórcio dos pais começaram a recusar contato e hostilizar um dos genitores sem que houvesse motivos reais ou justificáveis. As crianças passavam a denegrir, recusar ou repudiar pai ou mãe que sempre haviam sido bons genitores, e com os quais tiveram um histórico antecedente de forte vínculo afetivo.

Os relatos dessas crianças apresentavam justificativas irreais, absurdas ou banais para sua animosidade em relação ao genitor, designado por genitor alienado. A justificativa da criança não era baseada numa percepção real dos fatos nem condizia com a relação que sempre 
tivera com o genitor em questão. A percepção distorcida da criança acerca do genitor era muito semelhante às ideias exageradas, fantasiosas, projetivas ou delirantes que o genitor alienador apresentava de seu excônjuge. A criança foi definida, então, com o termo criança alienada.

Diante dessa constatação, o psiquiatra notou que tais crianças apresentavam um quadro sintomatológico em comum e uma causa específica para os sintomas - a programação do genitor alienador. Gardner utiliza o termo programação como sinônimo de lavagem cerebral (que ocorre a partir das atitudes e manipulações do genitor alienador). A designação, porém, não equivale à definição de Síndrome de Alienação Parental por ser este um diagnóstico que abrange a etiologia e as manifestações da doença na criança e não somente as atitudes do genitor alienador. A relação entre a causa e os oito sintomas que definem a patologia foi denominada Síndrome de Alienação Parental (SAP).

É necessário deter-se no significado médico do termo síndrome para compreender como Gardner define precisamente a SAP. Gardner adota a definição de síndrome utilizada por Campbell (1989, p. 717, citado por Gardner, 2003): "Uma coleção ou agrupamento de sinais e sintomas disjuntos e variáveis cuja frequência de ocorrência conjunta sugere existir um processo patológico singular ou distúrbio que os explica" (p. 98). A definição no dicionário de Psiquiatria Campbell's prevê ainda três níveis de reconhecimento de uma síndrome. Gardner identifica a SAP no terceiro nível, no qual se identificam sintomas e sinais reunidos em torno de um agente etiológico específico, isto é uma causa - o genitor programador. A campanha da criança, o genitor alienador, entre outros sintomas, são elencados por Gardner como elementos que podem contribuir para a SAP, mas não como causa desta.

A definição de SAP, ao trazer o termo Síndrome, inaugura um tipo específico de Alienação Parental, este último conceito mais amplo quanto a possíveis causas. Portanto na SAP, diferentemente da AP, a dificuldade de contato da criança com o genitor alienado e as distorções de percepção 
desta em relação ao genitor rechaçado são geradas a partir de uma lavagem cerebral realizada pelo genitor alienador ou programador.

Desse modo, a SAP aparece como um subtipo da AP, sendo esta última uma classificação mais genérica. A Alienação Parental engloba todas as situações que explicam a alienação de uma criança em relação ao genitor rechaçado, desde situações reais, como abusos, negligência e maus-tratos, até mesmo outros motivos como revoltas adolescentes, sedução de jovens por cultos religiosos, problemas na capacidade de parentalidade de um genitor, entre outros. Igualmente à $A P$, o autor refere que a SAP pode acometer adolescentes propondo a mesma teoria explicativa da patologia na criança. Ao definir SAP e AP, Gardner traz em sua teorização, uma contribuição ao diagnóstico diferencial da rejeição de crianças aos pais.

Algumas consequências da distinção entre os dois termos podem ser destacas: "(...) o diagnóstico da SAP requer identificação específica de um programador. Não existe outra possibilidade. Em contraste, o diagnóstico de PA não é específico e abre portas para ambos os genitores serem responsáveis pela alienação" (Gardner, 2006, p. 7). A necessidade da correta diferenciação acha-se ligada a problemáticas que surgem no sistema judiciário. A adequada proteção aos direitos da criança e do adolescente depende do esclarecimento das demandas que emergem no judiciário, isto é, da correta intervenção dos Operadores do Direito.

O desenvolvimento da Síndrome na criança pressupõe a combinação de dois elementos - a programação feita na criança por um dos genitores para denegrir o outro genitor e dele afastá-la e as contribuições da própria criança para sustentar a campanha contra o genitor alienado. No entanto, deve-se salientar que a SAP apenas se aplica como diagnóstico de patologia da criança ou adolescente e não dos parentes ou genitores, sendo característica do contexto de disputa de guarda. Dessa forma, o diagnóstico deve exclusivamente ser realizado no caso da apresentação dos sintomas pela criança e não quando existe unicamente a presença de um genitor programador. 
No entanto, Gardner sugere que, havendo um genitor alienador, mas ocorrendo a impossibilidade de diagnosticar a SAP devido à ausência de sintomas na criança, se diagnostique a presença do genitor programador com intuito de instalar a SAP. Para isso, faz-se necessário identificar o programador visto que ele realiza um abuso emocional contra a criança e os riscos de instalar a SAP são grandes, dependendo apenas de uma questão de tempo até que ela passe a apresentar a Síndrome e deferir animosidade contra o outro genitor.

Portanto, a definição do Dr. Gardner sublinha o fato de a criança ser uma participante ativa, junto ao progenitor alienador, para a difamação e a depreciação do genitor-alvo da SAP. Sem a contribuição da criança, não é possível diagnosticar a Síndrome até mesmo quando existe a prática de uma programação persistente por parte do alienador. Se a criança não responde à campanha do genitor alienador, não apresentará os sintomas típicos da SAP nem hostilizará seu ente querido.

Apesar de a teoria utilizar o termo genitor alienador, o autor menciona que outras pessoas que apresentem forte vínculo com a criança podem induzir a SAP, tanto de forma primária como secundária. Outros parentes podem ser os programadores principais, alienando os próprios genitores da criança. No entanto, mais comumente os parentes que convivem com a criança, participam como alienadores secundários, apoiando a campanha do genitor alienador. Gardner afirma que entre esses parentes alienadores primários ou secundários incluem-se avós, tios, padrastos, madrastas, entre outros.

\subsection{A CRIANÇA ALIENADA}

\subsubsection{Manifestações clínicas na criança alienada}

No livro básico para as reflexões deste trabalho, "The Parental Alienation Syndrome" (Gardner, 1998), o autor apresenta sua tese completa. Nele, encontramos a descrição da Síndrome e o quadro 1 para 
orientar mais facilmente os profissionais. Oito sintomas principais são definidos e classificados nos níveis leve, moderado e severo. Os três últimos itens referem-se ao diagnóstico diferencial.

O quadro apresenta-se como uma ferramenta psico-jurídica para auxiliar no diagnóstico da criança e fornecer elementos para balizar intervenções terapêuticas e decisões legais. O autor frisa que os critérios do quadro não são rígidos, dado que existe um continuum entre os níveis dos sintomas, uma vez que as crianças não apresentam todos os sintomas ao mesmo tempo.

\begin{tabular}{|c|c|c|c|}
\hline Fatores & \multicolumn{3}{|c|}{ Nível do sintoma da criança } \\
\hline $\begin{array}{c}\text { Manifestações } \\
\text { sintomáticas } \\
\text { primárias }\end{array}$ & Estágio Leve & Estágio Médio & Estágio Grave \\
\hline $\begin{array}{c}1 . \\
\text { Campanha de } \\
\text { desmoralização }\end{array}$ & Mínimo & Médio & Forte \\
\hline $\begin{array}{c}2 . \\
\text { Justificativas } \\
\text { fúteis, fracas ou } \\
\text { absurdas para a } \\
\text { depreciação }\end{array}$ & Mínimas & Moderadas & Múltiplas e absurdas \\
\hline $\begin{array}{c}3 . \\
\text { Ausência de } \\
\text { ambivalência }\end{array}$ & $\begin{array}{l}\text { Ambivalência } \\
\text { normal }\end{array}$ & $\begin{array}{c}\text { Nenhuma } \\
\text { ambivalência }\end{array}$ & $\begin{array}{c}\text { Nenhuma } \\
\text { ambivalência }\end{array}$ \\
\hline $\begin{array}{c}4 . \\
\text { Fenômeno de } \\
\text { independência }\end{array}$ & Geralmente ausente & Presente & Presente \\
\hline $\begin{array}{c}5 . \\
\text { Apoio deliberado } \\
\text { ao alienador no } \\
\text { conflito parental }\end{array}$ & Mínima & Presente & Presente \\
\hline $\begin{array}{c}6 . \\
\begin{array}{c}\text { Ausência de } \\
\text { culpa }\end{array} \\
\end{array}$ & Pouco & $\begin{array}{l}\text { Pouca ou nenhuma } \\
\text { culpa }\end{array}$ & Nenhuma culpa \\
\hline $\begin{array}{c}7 . \\
\text { Cenários } \\
\text { emprestados }\end{array}$ & Pouco & Presente & Presente \\
\hline $\begin{array}{l}\text { 8. Generalização } \\
\text { à família do } \\
\text { alienado }\end{array}$ & Mínima & Presente & Enorme e fanática \\
\hline $\begin{array}{c}\text { Considerações } \\
\text { adicionais ao } \\
\text { diagnóstico }\end{array}$ & Estágio Leve & Estágio Médio & Estágio Grave \\
\hline
\end{tabular}




\begin{tabular}{|c|c|c|c|}
\hline diferencial & & & \\
\hline $\begin{array}{c}9 . \\
\text { Dificuldades no } \\
\text { momento de } \\
\text { exercer as } \\
\text { visitas }\end{array}$ & Geralmente ausente & Médias & $\begin{array}{l}\text { Enormes ou visitas } \\
\text { impossíveis }\end{array}$ \\
\hline $\begin{array}{c}10 . \\
\text { Comportamento } \\
\text { durante a visita }\end{array}$ & Bom & $\begin{array}{l}\text { Hostil e algumas } \\
\text { vezes provocador }\end{array}$ & $\begin{array}{c}\text { Destruidor, } \\
\text { provocador ou } \\
\text { nenhuma visita }\end{array}$ \\
\hline $\begin{array}{c}11 . \\
\text { Laço com o } \\
\text { genitor alienador }\end{array}$ & Forte e sadio & $\begin{array}{l}\text { Forte e ligeira a } \\
\text { medianamente } \\
\text { patológico }\end{array}$ & $\begin{array}{c}\text { Gravemente } \\
\text { patológico, } \\
\text { frequentemente } \\
\text { paranoico }\end{array}$ \\
\hline $\begin{array}{c}12 . \\
\text { Laço com o } \\
\text { genitor alienado }\end{array}$ & $\begin{array}{l}\text { Forte, sadio ou um } \\
\text { pouco patológico }\end{array}$ & $\begin{array}{l}\text { Forte, sadio ou um } \\
\text { pouco patológico }\end{array}$ & $\begin{array}{l}\text { Forte, sadio ou um } \\
\text { pouco patológico }\end{array}$ \\
\hline
\end{tabular}

Quadro 1 - Diagnóstico diferencial dos três níveis de Síndrome de Alienação Parental (SAP) na criança

Fonte: Gardner (2006, p. 8).

Apresenta-se, a seguir, uma descrição detalhada dos oito sintomas com exemplos de casos clínicos de SAP (Gardner, 1998, p. 76-109).

1) Campanha de desmoralização

Este sintoma envolve de forma global todos os outros por resumir o aspecto mais característico da SAP, a depreciação do genitor. A SAP pode ocorrer sob formas fenomenológicas variadas, mas o denominador comum são as contribuições da criança para desmoralização e rejeição do genitoralvo.

A criança pode dizer que odeia o genitor e que nunca mais quer vêlo. Recusa-se a lembrar de momentos e eventos com o genitor alienado ou refere que não se recorda. Fala do genitor de forma ofensiva, sem sentir culpa ou constranger-se. Desrespeita sua autoridade apesar de sentir um amor e uma ternura que não podem ser externalizados. Pode, ainda, apresentar gratificações mórbidas em frustrar ou maltratar o genitor por saber que não sofrerá medidas por parte do genitor alienador. Ela sabe que, se o genitor alienador ameaçar punir, o faz sem convicção, apenas para ser visto publicamente. 
Os irmãos mais velhos podem ajudar o genitor a alienar os mais novos, servindo de vigias quando a criança menor demonstra inclinação ou afeto em relação ao genitor alienado.

Telefone, caixa postal, secretária eletrônica, identificador de chamadas e campainha são apontados como poderosos instrumentos utilizados como via de obstrução de contato pelo genitor programador.

Crianças alienadas podem fazer divisão rígida de seus objetos (roupas, pertences, brinquedos) entre as duas residências. A criança aprende que qualquer coisa trazida da casa do genitor alienado vai despertar reações hostis no alienador, o que irá afetá-la. Assim, quando vem da casa do genitor-alvo, troca de roupas ao entrar na casa do programador para evitar comentários negativos, como Suas roupas estão muito sujas.

A contribuição da criança para a campanha de desmoralização contra o genitor-alvo revela-se em sua cumplicidade com as manifestações do alienador e em sua participação ativa na alienação. Ela fornece ao programador novos materiais que não foram anteriormente por ele mencionados ou orientados. Muitas vezes são elaborações improváveis, incongruentes, o que gera suspeita quanto à veracidade do que é alegado. Gardner (1998) afirma:

A presença de contribuições absurdas foi o que primeiramente me levou à conclusão de que a campanha da criança não era simplesmente o resultado da programação parental; a contribuição da própria criança tinha importante papel em aumentar e enriquecer os cenários para depreciação do genitor alienado. (p. 77)

A forma mais grave da campanha ocorre quando a criança alega ter sido sexualmente abusada pelo genitor-alvo. Os enredos que a criança inventa por conta própria vão além daqueles criados pelo alienador. Ela pode expressar diretamente a contribuição do genitor programador, ou então sua contribuição pode ser criada a partir de algum elemento fornecido pelo alienador. 
Gardner diferencia dinâmicas presentes na SAP e nos divórcios em geral. Afirma ser comum certo tipo de manipulação feita pelas crianças na ocasião do divórcio. Demonstram afeto por um dos pais, manifestando críticas e animosidade a respeito do outro. No entanto um genitor saudável não explora essas manifestações infantis nem utiliza a informação da forma como um programador de SAP. Quando não existe um alienador, a criança faz críticas a ambos os pais e pede-lhes segredo para que não seja descoberta em suas artimanhas. Na SAP, a criança manifesta-se de forma intensa e hostil contra um dos genitores, mantendo-se cúmplice do outro genitor em sua missão de denegrir o outro. Porém nem toda manifestação crítica da criança representa uma manifestação de SAP, embora os conflitos de lealdade possam ser um terreno fértil para um dos genitores instalar a SAP.

Gardner cita exemplos de campanha de desmoralização da criança. Em alguns deles, pode-se perceber a participação do alienador, em outros ela aparece encoberta. Um menino, durante as lições de casa, recusavase a escrever o nome do pai quando era necessário, escrevendo em seu lugar a palavra cachorro. Outro menino de 11 anos, quando o pai ligava, atendia e dizia $O$ número que você discou não existe. Em seguida desligava. Semanas depois seu irmão de 5 anos passou a fazer o mesmo.

Um garoto disse que seu pai pediu para ele não falar com sua mãe nem com seu padrasto durante o jogo de futebol. O pai alienador negou que tivesse dito isso ao filho, confirmou, no entanto, que dissera que, definitivamente, não suportava seu padrasto.

Outro garoto sabia de cor o telefone do advogado da mãe. Disse que nunca tinha ocorrido algo durante as visitas paternas, mas era bom saber o telefone do advogado caso precisasse. Disse que antes de cada visita paterna sua mãe verificava se ele tinha decorado o número, em seguida afirmava ao filho Caso aconteça algo.

2) Justificativas fúteis, fracas ou absurdas para a depreciação 
As crianças alienadas fornecem justificativas irracionais, fracas, fúteis ou absurdas para sua animosidade contra o genitor-alvo. Podem justificar sua rejeição a partir de lembranças de pequenas discussões que tiveram com seus pais. Ele sempre fala muito alto comigo quando me manda escovar os dentes. Quando pedido que deem razões mais convincentes para a recusa ao genitor são incapazes de fazê-lo.

Na SAP, o motivo alegado pela criança não justifica o grau de animosidade manifestado. Crianças disseram que se recusavam a ir à casa do pai explicando: A bicicleta na casa da minha mãe é melhor que da casa de meu pai, ou então, Ele nunca deixa a gente correr pela casa, e ainda, Ele me faz sentar e ficar quieto durante o jantar. Algumas vezes a criança simplesmente responde não querer visitar o genitor, dando referências vagas ou pejorativas: Eu não gosto dele, ou Eu não suporto ele, tendo muita dificuldade em dar mais explicações ou dizer o porquê de não gostar do genitor.

Uma criança de 5 anos apresentou uma justificativa fútil para não querer visitar o pai, disse que a razão para tal era que sua avó paterna costumava mimá-la e dar muitos presentes. Outra criança explicou sua rejeição às visitas dizendo que costumava emagrecer na casa de seu pai e voltava a ganhar peso ao voltar para a casa da mãe.

Uma criança ofereceu uma explicação absurda para nunca mais ver seu pai afirmando que ele tinha cabelos oleosos. Quando perguntado à mãe se o pai tinha cabelos oleosos, esta afirmou: Não lembro de ele ter esse problema quando éramos casados, mas quem sabe que porcaria ele tem passado na cabeça para sair com a nova namorada.

Comportamentos normais e saudáveis por parte dos progenitores alienados são interpretados com má-fé e convertidos em razão para a rejeição. Um garoto de 8 anos afirmou que não queria ver seu pai porque ele não o deixava ver TV antes de terminar a lição e que não o deixava sair da cozinha enquanto não tirasse o prato da mesa e colocasse na pia.

Numa sessão de família, dois irmãos disseram que nunca haviam tido momentos agradáveis com seu pai como motivo para não visitá-lo. 
Quando o pai mostrou fotos com todos alegres, o garoto de oito anos disse que eram fotos falsificadas, em seguida a criança de 6 anos repetiu a mesma frase. É comum que crianças mais novas frequentemente imitem irmãos mais velhos em casos de SAP. Quando perguntado à mãe se ela acreditava que aquelas fotos eram fabricadas, ela disse que eram reais, mas que seu ex-marido nunca perguntava às crianças se elas queriam de fato ir a esses lugares.

Uma garota disse a seu pai que, se ele fosse ver sua apresentação na escola, ela sairia do palco e chamaria a polícia. Quando perguntado o que ela pensava que poderia ocorrer se seu pai fosse à escola, ela respondeu: Não sei, talvez ele pudesse atirar em mim com uma arma.

É comum que o genitor seja acusado de quebrar promessas que até mesmo nunca foram feitas. Os deveres do lar são muitas vezes apontados como razões para recusa à visita. Na casa do alienador, a criança faz as mesmas tarefas que na casa do genitor alienado, mas com mínima resistência. Na casa do genitor alienado, elas se tornam queixas de submissão e exploração. As tentativas de manter contato ou de corrigir a percepção da criança sobre sua pessoa são geralmente tomadas como mais um motivo para a não visitação.

3) Falta de ambivalência

A maioria das crianças consegue dar exemplos de coisas boas e ruins a respeito de cada um de seus pais. As relações humanas são ambivalentes, assim as relações parentais não são exceção. No entanto, em crianças alienadas, não se observa esse aspecto. O parente alienado é completamente ruim e o alienador completamente bom. Criticam o genitor alienado não sendo capaz de afirmar uma qualidade. Com relação ao alienador, referem apenas qualidades, não conseguindo dar nenhum exemplo de algo de que não goste nele.

Um garoto disse: Meu pai sempre me faz escovar os dentes e minha mãe nunca me faz escovar. Outro disse que nunca se divertia na casa do pai enquanto que na casa da mãe ele sempre se divertia. Quando 
perguntado se isso era verdade, afirmou que nunca teve nenhum momento de diversão na casa do pai.

Quando são mostradas fotos de momentos agradáveis com os genitores alienados a essas crianças, a memória dessas experiências é obliterada como se tivessem sido esquecidas, fossem inexistentes ou fingidas. Eu odiei estar ali com ele, eu sorri porque ele me obrigou. Também ocorrem amnésias das lembranças antes do período de separação dos pais.

4) Fenômenos de independência

Crianças alienadas podem afirmar orgulhosamente a decisão em rejeitar o progenitor, ao passo que negam qualquer incentivo do alienador. O programador afirma desejar as visitas e ser importante 0 envolvimento dos filhos com o outro genitor. No entant, suas atitudes são opostas, pois apoia a independência da criança em escolher se quer ver o genitor e nega repetidamente que contribuiu para essa rejeição, especialmente na frente dos filhos, dizendo que a animosidade da criança não vem dele.

A criança acredita que, afirmando que decide por conta própria evitar o genitor, alivia a responsabilidade do alienador, protegendo-o de críticas. O genitor programador afirma orgulhosamente que os filhos têm pensamentos próprios e são corajosos para expressar suas opiniões, incentivando a ilusão da criança de ter um pensamento independente. Nega na presença da criança, e na frente de outros adultos, suas atitudes, reafirmando sua inocência como se estivesse ajudando nas visitações.

A recusa da criança de que o genitor alienador a influencia é protestada bravamente. No entanto, crianças que expressam sua opinião não precisam denegar a influência do genitor.

Uma criança disse: Eu não preciso ir no cinema com meu pai se eu não quiser. Eu tenho meus direitos também.

Uma mãe costumava sempre criticar o pai de seus filhos na frente deles, dizendo que ele não respeitava seus sentimentos e que eles não 
queriam visitá-lo porque não gostavam dele. Ela colocou na mente das crianças a noção de que a decisão de não visitar era delas e que ela estava apenas reforçando o que sentiam.

Frequentemente os alienadores forçam as crianças a dizer a verdade, isto é, se elas realmente querem visitar o outro genitor. As crianças acreditam que a verdade é o que elas protestam. Uma mãe disse a seu filho: Me diga, Billy, eu quero que você me diga a verdade. Você realmente quer ver seu pai? Depois de algumas intervenções desse tipo, a criança passa a acreditar que a recusa ao genitor é sua própria vontade e sempre foi. No entanto, a presença de palavras e frases emprestadas do alienador desmente os pensamentos que afirmam ser independentes.

Afirmar ter um pensamento próprio dá à criança um sentido de poder que se revela uma autoilusão. Na realidade, a criança está sendo explorada, subjugada e transformada em instrumento de batalha, pois estão sempre sendo demandado que negue as próprias percepções e experiências.

5) Apoio deliberado ao genitor alienador no conflito parental

A criança com SAP sempre está do lado do alienador e pode até apresentar argumentos mais fortes do que os do genitor alienador para sua animosidade.

Uma mãe queixava-se de que seu ex-marido não lhe dava nenhum dinheiro. Quando o pai mostrou à criança os cheques assinados por ele nominais a sua mãe e que foram cancelados no banco por ela, o garoto afirmou que o pai havia falsificado tais papéis só para mostrar a ele.

Essas crianças aceitam todas as alegações do genitor programador contra o alienado. A mãe de um garoto reclamava que seu ex-marido havia batido nela várias vezes. Esse era o mesmo motivo alegado pelo garoto para não querer mais visitar o pai. Quando a criança foi questionada se alguma vez tinha visto cenas de espancamento, afirmou que não, mas que acreditava em sua mãe, que ela nunca mentira, mas 
que seu pai sempre o fizera. Ele não soube, no entanto, dar nenhum exemplo de alguma mentira que seu pai tivesse dito.

6) Falta de culpa, crueldade e exploração do genitor alienado

A criança exibe falta de culpa em relação ao genitor vitimizado. Ela não demonstra senso de gratidão pelos presentes, pelo suporte financeiro e por outras manifestações do genitor. Mesmo que o genitor continue oferecendo todo o apoio necessário à criança, ela evita contato. O genitor alienador e a criança não veem nada de repreensivo em continuar a fazer demandas, mesmo que a criança se recuse $a$ ir às visitas. Elas não sentem culpa pela crueldade nem pela exploração do genitor. Uma mãe, por exemplo, dizia que queria o dinheiro extra que o outro genitor dava, sem obrigações atreladas, sem que os filhos tivessem de fazer as visitas.

O programador induz a criança a níveis elevados de crueldade, porém ela não tem consciência dos efeitos no genitor. $O$ exemplo mais severo ocorre quando o alienador produz na criança a criação de falsas alegações de abuso sexual de forma deliberada e consciente. Os genitores-alvo são totalmente destruídos e muitas vezes mandados para a cadeia. A falta de culpa da criança deve-se tanto à imaturidade cognitiva, no caso de crianças muito pequenas, quanto à facilidade com que crianças podem ser programadas.

Outras crianças podem ser estimuladas pelo alienador a roubar dinheiro, objetos, documentos da casa do genitor alienado, algumas vezes podem destruir móveis e outros pertences. Outras são estimuladas a ter comportamentos sádicos. Um garoto riscou todo o carro de seu pai. Dois adolescentes, de 13 e 15 anos, jogaram sopa na cabeça de seu pai no meio do restaurante e saíram rindo. Outro disse: Não existe maior prazer do que ver você chorar.

7) Presença de cenários emprestados

Crianças vítimas de SAP utilizam termos que não são comuns para sua idade e apresentam um discurso maçante e ensaiado. Os termos e 
frases usados pelo genitor alienador tornam-se o enredo das expressões de hostilidade da criança.

As crianças, principalmente quando bem pequenas, não se dão conta de que estão revelando a fonte de sua informação ao fornecer os cenários emprestados (que podem ser expressões, palavras ou versão) do alienador. Por exemplo, uma criança disse: Mamãe disse que ele tocou no meu pipi.

Certo pai tentava contato com seu filho por telefone, mas toda vez que a genitora atendia, ela dizia Pare de nos atormentar!, desligando em seguida. A criança de quatro anos, quando questionada por que não queria ver seu pai respondeu: Ele nos atormenta!. Quando instada a definir o termo emprestado, a criança geralmente é incapaz de fazê-lo de maneira satisfatória e de fornecer exemplos que sustentem suas alegações.

Em alguns casos, as crianças escrevem cartas para os juízes queixando-se de que não querem visitar seus genitores. Essas cartas fazem parte da campanha de desmoralização, porque o genitor alienador tem de estar envolvido ao menos para redigir a carta.

Uma criança de 9 anos disse que seu pai queria que ela fosse abortada quando a mãe soube que estava grávida dela. A criança confirmou que a mãe lhe contara isso.

Um menino de 5 anos recusava-se a ir à casa de seu pai enquanto a namorada dele estivesse lá, mas não sabia explicar o motivo. Houve, no entanto, um episódio anterior, logo que a mãe ficara sabendo da nova relação amorosa do pai. Ela levou o menino e sua irmã mais velha à casa do pai, ao chegar à porta da casa, instruiu que a irmã entrasse para certificar-se de que a namorada do pai estava lá e ligasse em seguida em seu celular para avisar. Caso ela estivesse presente, ela deveria sair imediatamente da casa do pai e retornar ao carro da mãe. A criança confirmou e, então, a mãe levou os dois filhos embora. O menino foi testemunha do evento e passou a recusar-se a ir à casa do pai. 
Um adolescente reclamou para sua mãe que o pai estava submetendo-o e a seus irmãos a trabalho escravo. Ela confirmou na frente dos filhos que seu ex-marido os explorava. Foi verificado que tais atividades eram apenas tarefas básicas do lar. Em seguida, o irmão de seis anos começou a queixar-se também de trabalho escravo.

8) Animosidade à família estendida do genitor alienado

$\mathrm{O}$ ódio do genitor alienador muitas vezes se estende à família do genitor alienado. Primos, tios, tias e avós com os quais a criança sempre teve uma boa relação, repentinamente se veem rejeitados. Também pode haver rejeição dos amigos do genitor-alvo e dos filhos destes. A criança recusa presentes, cartões deixando-os intocados ou até mesmo destruindo-os. Pode ficar furiosa quando estes ligam, desligando o telefone, comportamento ainda mais comum quando o alienador está próximo.

Crianças alienadas recusam o contato com seus parentes com a desculpa de que tentam influenciá-la a melhorar a relação com o genitor alienado.

\subsubsection{Grau da Síndrome}

Conforme a extensão dos sintomas, Gardner define três estágios da SAP - leve, moderada e severa - tanto para a criança como para o programador. O autor propõe essa diferenciação entre os níveis da SAP com $o$ intuito de indicar tratamento específico e adequado conforme a gravidade dos sintomas de forma que oriente separadamente duas frentes de atuação: as equipes de saúde mental e os profissionais de direito. Resumidamente, os níveis de sintoma na criança são apresentados a seguir. 


\subsubsection{Casos leves de SAP}

Neste estágio, a criança tem como principal motivo apoiar o genitor guardião no processo judicial e manter forte a vinculação com ele. Nesta etapa, as visitas com o genitor-alvo ainda ocorrem normalmente. Como ainda ocorrem as visitas, o contato da criança com o genitor alienado ajuda a frear a SAP. "A relação serve de antídoto contra a doutrinação do alienador", afirma Gardner (p. 120). As crianças tanto apresentam poucos dos oito sintomas da SAP como estes aparecem de forma mais superficial. Sentem-se livres para expressar seu afeto pelo outro genitor e as manifestações de depreciação, quando aparecem, são leves e intermitentes. A relação com o genitor alienado normalmente é forte e quase não existem dificuldades no momento de transição das visitas; quando existem, são facilmente revertidas.

\subsubsection{Casos moderados de SAP}

Geralmente, nesta etapa, grande parte dos oito sintomas está presente. A depreciação da criança aparece mais forte, principalmente quando está na frente do alienador. Apesar de observar-se muita relutância dos filhos às visitas, frequentemente elas acontecem. Gardner (1998) observa:

O tempo de transferência entre as visitações são períodos nos quais esses problemas mais aparecem. Quando o genitor-alvo vem para visitação, a criança frequentemente recusa-se a ir com ele (ela) fornecendo desculpas fracas que são apoiadas pelo genitor alienador. Mais tarde, quando a criança está sozinha com o genitor vitimizado, ela pode baixar a guarda e começar desfrutar a visita. E então, como se percebesse que está fazendo algo "errado", repentinamente se retrai, evitando envolvimento e expressando animosidade. (p. 83)

A criança apresenta apoio deliberado ao alienador no conflito, falta de ambivalência em relação às figuras parentais e certa falta de culpa em crueldade contra o genitor. O principal motivo da criança em sustentar a campanha deve-se à manutenção da vinculação com o alienador. 


\subsubsection{Casos severos de SAP}

Neste estágio, todos os sintomas ou quase todos se apresentam intensamente pronunciados. As crianças são fanáticas, perturbadas e apresentam fantasias paranoides em relação ao genitor-alvo. As visitas geralmente não ocorrem neste estágio da SAP. Em alguns casos a criança pode visitar algumas vezes o genitor para causar danos, como roubar, destruir móveis e humilhá-lo. Gardner exemplifica alguns casos em que a criança roubava dinheiro do alienado e outro caso em que a criança tentou atear fogo à casa do genitor. Nessa fase:

A escassez das visitas ou a falta de contato com o genitor rechaçado podem facilitar que a criança aceite as críticas do genitor alienador. Existem poucas ou nenhuma oportunidade de corrigir as distorções por meio de experiências atuais. (Gardner, 1998, p. 131)

Em outras crianças com SAP severa, há a possibilidade de as visitas gerarem ataques de pânico, ódio, estado agitado, gritos. Na presença do genitor-alvo, as crianças podem correr ou paralisar-se em pânico, provocá-lo ou serem destrutivas a ponto de terem de ser retiradas da presença do alienado. A relação com o genitor alienador revela-se patológica, geralmente paranoide. Nota-se uma dificuldade de diferenciação entre os filhos e o alienador, que geralmente se referem com o uso do pronome "nós". Comumente, diagnostica-se "folie à deux"1 do DSM (Diagnostic and Statistical Manual of Mental Disorders)

\subsubsection{Psicodinâmica da criança alienada}

Gardner considera que nem toda contribuição à SAP provém do alienador, algumas derivam de fatores psicopatológicos da criança.

O desejo de preservar o laço com o genitor com o qual teve um vínculo primário, geralmente as mães, aparece como um dos principais

\footnotetext{
1 "Uma pessoa mais assertiva e coercitiva induz uma patologia delirante em uma pessoa mais passiva e submissa". (Gardner, 1998, p. 123) No caso da SAP, a criança revela-se submissa à coerção do alienador e os delírios são centrados no genitor alienado.
} 
motivos para a criança contribuir ativamente com a campanha. No entanto, o medo do rompimento do vínculo com o genitor pode ser um fator mais poderoso e contribuidor da SAP do que a necessidade de preservação do vínculo. O medo do genitor alienado também pode ser mais um fator, uma vez que o genitor programador comunica à criança que, se ela manifestar afeto pelo outro genitor, pode ser rejeitada. Alguns alienadores podem até mesmo terrorizar os filhos.

Gardner cita a reação formativa como outro fator participante na rejeição dos filhos que sentem ódio obsessivo em relação ao alienado. $O$ ódio pode ser expresso em razão da culpa e do medo de expressarem o amor pelo genitor alienado.

A identificação com o agressor, o genitor alienador, pode ser um importante elemento ao entendimento da contribuição da criança. $O$ autor explica que as agressões e ataques de raiva do alienador podem levar a criança a identificar-se com ele por receio de que essas agressões se voltem contra ela caso se una ao genitor vítima dos ataques. Outro tipo de identificação, mas com o genitor idealizado (alienador), pode igualmente influenciar no desenvolvimento da Síndrome. A identificação com genitor tão depreciado (genitor alienado) fica comprometida fazendo com que a criança tome apenas o programador como modelo, mas este por sua vez é idealizado.

Crianças que passam pela separação dos pais podem sentir muitas frustrações e ressentimentos em função da separação, do conflito entre os pais e da crença de terem sido abandonadas por um deles. $O$ desenvolvimento da SAP pode servir como via de escape para expressão da raiva e dessas frustrações. A liberação da raiva participa como mais um fator que pode servir ao desenvolvimento da SAP ou ajudar a intensificá-la.

O poder da criança sobre o outro genitor pode ter importante papel no desenvolvimento da SAP. Os filhos alienados aprendem que têm poder sob o genitor-alvo ao recusarem sua autoridade, pois o genitor alienador 
ensina que as medidas disciplinares ou restrições do genitor alienado são abuso ou assédio.

Gardner refere-se também à capacidade de contágio das emoções. Os ataques de raiva e dramatização do alienador podem contagiar as crianças sem que elas saibam exatamente por que estão agindo daquela forma.

A rivalidade sexual pode ajudar no aumento da SAP. O novo relacionamento amoroso do genitor alienado pode fazer a relação com o filho deteriorar-se rapidamente, pois o ciúme, que seria natural em outras crianças, será intensificado pelo alienador como instrumento de retaliação para gerar uma animosidade da criança.

\subsection{O GENITOR ALIENADOR}

\subsubsection{Manifestações clínicas do genitor alienador}

O genitor alienador induz a criança à SAP após a separação, usandoa como instrumento de retaliação contra o ex-cônjuge. O genitor alienador sente raiva constantemente, faz retaliações e ciladas contra o genitor. Ele pode intensificar a campanha ou iniciá-la depois de algum evento que provoque desagrado. Por exemplo, quando o outro genitor casa, começa a namorar, quando a pensão estipulada é abaixo do esperado, quando está insatisfeito com a partilha de bens, entre outros.

Geralmente, os genitores que induzem a SAP detêm a guarda dos filhos porque o fator tempo na alienação revela-se fundamental para a campanha surtir efeitos. Mas, conforme exposto anteriormente, pode existir um alienador secundário e até mesmo outros parentes no papel de alienadores primários.

Embora afirme que as manobras podem ser feitas tanto pelos pais como pelas mães, o autor define que algumas estratégias são mais comumente feitas por homens e outras por mulheres. Os pais geralmente realizam uma campanha mais planejada, obsessiva. Não o fazem ao longo 
do dia como as mães, que incluem a programação nas atividades de rotina. Geralmente, o alienador homem é menos disponível em termos de tempo do que as mães, sendo assim, para ser eficaz, precisa dedicar-se a sessões, momentos reservados a esse propósito. Segundo Gardner (1998):

Ao longo dos anos, minha experiência tem revelado que as mães têm maior probabilidade do que os pais em induzirem a Síndrome de Alienação Parental (SAP) em seus filhos. Não se trata exatamente de que os pais não tentem, mas eles têm sido bem menos eficazes. (p. 127)

O diagnóstico do genitor alienador a que Gardner se refere, consiste na avaliação da tenacidade, extensão e intensidade da programação, o principal elemento para definir a guarda. Apesar de o diagnóstico de SAP ser baseado no nível de pronunciamento dos sintomas da criança, a decisão judicial para mudança de guarda deve ser primeiramente baseada nos níveis dos sintomas do alienador e posteriormente no nível dos sintomas da criança. Uma criança pode estar no nível leve de alienação, mas, se o genitor apresentar grau severo de programação, em questão de pouco tempo a criança estará completamente alienada do outro genitor. $\mathrm{O}$ autor criou um quadro para ajudar a distinguir os principais elementos a serem considerados durante a tomada de decisões pelos profissionais.

\begin{tabular}{|l|c|c|c|}
\hline \multicolumn{1}{|c|}{ Fatores } & Leve & Moderado & Severo \\
\hline $\begin{array}{l}\text { Presença de } \\
\text { psicopatologia } \\
\text { antes da } \\
\text { separação }\end{array}$ & $\begin{array}{c}\text { Quase sempre } \\
\text { ausente }\end{array}$ & $\begin{array}{c}\text { Pode ou não estar } \\
\text { presente }\end{array}$ & $\begin{array}{c}\text { Quase sempre } \\
\text { presente }\end{array}$ \\
\hline $\begin{array}{l}\text { Frequência de } \\
\text { pesamentos } \\
\text { programadores }\end{array}$ & Eventual & Frequente & Persistente \\
\hline $\begin{array}{l}\text { Frequências de } \\
\text { verbalizações de } \\
\text { programação }\end{array}$ & Eventual & Frequente & $\begin{array}{c}\text { Sempre que } \\
\text { possível }\end{array}$ \\
\hline
\end{tabular}

\footnotetext{
${ }^{2}$ Por exemplo, Transtorno Psicótico Compartilhado (folie à deux), Transtorno Delirante, Transtorno de Personalidade Paranoide, Transtorno de Personalidade Borderline, Transtorno de Personalidade Narcisista e Transtorno de Personalidade antissocial.
} 


\begin{tabular}{|l|c|c|c|}
\hline $\begin{array}{l}\text { Frequência de } \\
\text { manobras de } \\
\text { exclusão }\end{array}$ & Eventual & Frequente & Repetida \\
\hline $\begin{array}{l}\text { Frequência de } \\
\text { queixas à policia e } \\
\text { a serviços de } \\
\text { proteção à criança }\end{array}$ & Eventual & Frequente & Repetida \\
\hline Litigiosidade & Eventual & Frequente & Repetida \\
\hline $\begin{array}{l}\text { Episódios de } \\
\text { Histeria }\end{array}$ & Eventual & Frequente & Bem frequente \\
\hline $\begin{array}{l}\text { Frequência de } \\
\text { violação de ordens } \\
\text { judiciais }\end{array}$ & Eventual & Frequente & Repetida \\
\hline $\begin{array}{l}\text { Sucesso em } \\
\text { manipular o } \\
\text { sistema legal para } \\
\text { aumentar a } \\
\text { alienação }\end{array}$ & Poucas tentativas & Eventual a & $\begin{array}{c}\text { Diversas } \\
\text { moderado } \\
\text { sucedidas bem- }\end{array}$ \\
\hline $\begin{array}{l}\text { Risco de aumentar } \\
\text { a programação se } \\
\text { ganhar a guarda } \\
\text { unilateral }\end{array}$ & Muito baixo & Leve a moderado & $\begin{array}{c}\text { Extremamente } \\
\text { alto, praticamente } \\
\text { inevitável }\end{array}$ \\
\hline
\end{tabular}

Quadro 2 - Diagnóstico dos três níveis de Síndrome de Alienação Parental - Alienadores Fonte: Gardner (2006, p. 9).

Entre as manifestações típicas de genitores alienadores incluem-se manobras, manipulações, táticas psicológicas e implementação de falsas memórias, realizadas sistematicamente pelo alienador. Podem ser conscientes, inconscientes, explícitas ou encobertas. O que pode iniciar-se como uma fabricação consciente, pode tornar-se inconsciente, automático e profundamente incorporado, fazendo com que esse genitor não tenha consciência do mal causado aos filhos. A campanha pode durar por longos anos e, quando realizada diariamente, trata-se de uma questão de tempo até que a criança passe a realizar a campanha de desmoralização junto ao genitor alienador.

\footnotetext{
3 Por exemplo, obstrução de visitação, bloqueio de acesso ao telefone, falha em enviar informações escolares, médicas e do tratamento psicológico.

4 São características principais da histeria: explosões emocionais, reações exageradas, presunção de perigo quando não há, dramatização, comportamento de chamar a atenção, deficiência no julgamento, liberação de raiva culpando outros, capacidade de contágio da emoção e intensificação dos sintomas no contexto do processo.

${ }^{5} \mathrm{O}$ alienador pode contar com $\mathrm{O}$ atraso do judiciário e relutância e até mesmo com a recusa em penalizar o alienador com medidas como: fiança, multa, serviço comunitário, liberdade vigiada, prisão domiciliar, encarceramento e mudança de guarda.
} 
A repetição das mensagens do alienador à criança ao longo do tempo revela-se uma das técnicas mais essenciais ao entendimento do desenvolvimento da Síndrome, pois engloba de forma geral a prática de todas as outras.

O uso do telefone, secretária eletrônica, identificador de chamadas são importantes instrumentos para a realização da campanha. A criança pode receber inúmeras ligações ao longo do dia feitas pelo genitor alienador quando está visitando o genitor alienado. Essas ligações podem ser muito longas, atrapalhando o desenrolar das visitas e tirando o máximo de tempo junto ao outro genitor. Depois de ouvir frases como eu realmente espero que você esteja bem, sinto sua falta, estou triste, estou sozinho ou fiquei doente quando você partiu, a criança passa a chorar ou a querer ir embora para a casa do genitor alienador. As ligações podem ter $o$ intuito de inquirir passo a passo tudo o que a criança fez na casa do outro genitor.

Por outro lado, quando a criança está na casa do genitor alienador, o outro genitor é impedido de falar ao telefone com a criança. O identificador de chamada pode ser utilizado para não atender às chamadas do alienado e a criança passa a imitar o comportamento do alienador, não atendendo quando percebe no aparelho o número do outro genitor. Quando este consegue ligar, o genitor programador diz: está no banho, está dormindo, não está. Essas frases são repetidas sistemática e diariamente sem constrangimento, algumas vezes até mesmo na frente dos filhos. Quando a criança atende ao telefone, o alienador coloca vivavoz para controlar a situação e tirar a espontaneidade da conversa entre criança e alienado. Os filhos podem, também, ser induzidos a mentir que o genitor alienador não está em casa. Juntos, alienador e criança, podem fazer zombarias a respeito do genitor, dar gargalhadas quando ele liga, ou, então, desligar na sua cara. Tais técnicas têm como objetivo obstrução de contato, controle e desmoralização.

Gardner enfatiza que o alienador faz excessivas demonstrações públicas de amor à criança. Ele apresenta um excesso de zelo na partida 
da criança às visitas com o genitor alienado como se precisasse protegê-la de um perigo, como se o genitor fosse nocivo ou descuidado. Quando a criança está na casa do outro genitor, o alienador, por telefone, diz estar morrendo de saudades.

Gardner comenta uma técnica que chama de "retirada de amor": o alienador ameaça a criança de perder seu amor se ela não compactuar com ele na desmoralização do outro genitor. Outra técnica é a do "fazerdesfazer": Como assim você vai na casa dela? Ah! Desculpa, eu não deveria fazer isso. É errado. Segundo Gardner, dizer frases como essas e retirar não é o mesmo que nunca ter dito.

São comuns alguns fingimentos e dramatizações por parte do alienador na frente da criança ou de outras pessoas, procurando mostrarse vítima. Numa conversa entre os pais, o alienado, ao perceber a presença da criança, pode mudar o assunto e dizer: Não se refira a ele desta forma!, Ainda bem que nosso filho não está escutando o que você diz dele, ele não falaria nunca mais com você, Isso é a sua opinião. Na minha, ele é uma ótima criança. Com isso demonstra defender a criança contra ataques do outro genitor, que na realidade estão sendo simulados. O alienador, quando fala ao telefone com o genitor alienado, pode dizer em tom alto para a criança ouvir: Pare de chamá-lo de burro! Pare de falar mal dele!, quando na realidade o genitor falava sobre outro assunto. Dessa forma a criança pensa que o genitor a desqualifica. O alienador quando está sozinho com o genitor alienado pode gritar: Não me bata! Não me bata! para a criança pensar que ele agride o outro genitor, quando nada disso está ocorrendo.

Gardner descreve um exemplo clínico de cilada e fingimento por parte do pai alienador. O filho adolescente pedia constantemente ao pai para voltar a morar com a mãe. O pai disse certo dia que combinou com a mãe de o pegar às 3 da tarde, ao mesmo tempo em que combinou com a mãe de pegar o garoto às 17 . O pai saiu de casa às $15 \mathrm{~h}$, trancando a porta e deixando o filho do lado de fora esperando a mãe. Quando ela chegou às $17 \mathrm{~h}$, o filho estava agitado e raivoso, dizendo: Meu pai está 
certo. Você não liga para mim. Você está sempre atrasada e isso que aconteceu é uma prova. Você provavelmente estava trepando com seu namorado e por isso atrasou.

Também é comum fingir situações para sustentar uma versão negativa e distorcida da história para a criança, como dizer que não vai comprar algo pois o genitor não paga pensão ou que o dinheiro da pensão não é suficiente. Uma mãe disse à criança que, apesar de querer levá-la ao Mc Donald's, não seria possível porque o pai não the dava dinheiro suficiente, levando a criança a acreditar que ficaria sem as coisas mais básicas como roupa, comida e casa. O genitor alienador pode ainda deixar faltar itens básicos à criança para provar que a pensão é escassa. Pode distorcer fatos sobre a separação, sobre o não pagamento pensão, que o genitor não veio visitar, que ele abandonou a criança, que ele largou a família para ficar com a namorada dele. A mãe de uma criança arrumava o filho em dias que não eram visitas paternas para a criança acreditar que ele a esquecera. É comum o uso do pronome "nós" pelo genitor alienador para alinhar a criança a sua causa, por exemplo: ele nos abandonou.

São comuns falsos reportes de violência, de abandono, de maustratos para obter ganhos processuais, impactar os profissionais, vingar-se e/ou afastar o genitor da criança. Na volta de férias, o genitor pode ameaçar interromper as visitas, alegando que a criança veio com arranhões ou picadas de inseto, situações absolutamente normais. Podem dizer que o genitor não dá os remédios, ou que a criança ficou doente quando estava com ele. Afirmam que o genitor não trata a criança direito, que ele dá broncas ou não dá comida adequada ou suficiente. O genitor que aliena pode fazer falsos reportes às autoridades, de que foi agredido pelo outro genitor ou ainda que este abusou da criança física ou sexualmente. O uso de atestados médicos pelo alienador na volta das visitas ou férias com o genitor-alvo são comuns para tentar provar que ele não consegue cuidar da criança. Presentes, lembranças, fotos, objetos e roupas dadas pelo genitor podem não ser entregues a seus filhos. 
Também ocorre com frequência de o programador envolver a criança no conflito parental, colocando-a a par de assuntos que ela não deveria saber. Contar os problemas do casamento, da separação para denegrir a imagem do genitor alienado, como dizer: ele me traiu com aquela vadia da namorada dele. Ou, ainda, estimular que a criança escreva carta ao juiz pedindo que respeite a vontade dela para não visitar o genitor, contar os detalhes processuais.

Os alienadores normalmente exponenciam pequenos defeitos ou dificuldades do genitor alienado. Um genitor que experimentou maconha quando jovem facilmente é descrito para a criança como alguém que é "drogado" ou "dependente químico". Um genitor mais disciplinador facilmente vira um genitor que maltrata, explora menores ou obriga a criança a fazer trabalho escravo.

Exclui-se o genitor-alvo de atividades escolares da criança, comemorações, cursos, esporte, terapia, muitas vezes avisando em cima da hora ou simplesmente não informando. As informações sobre estado de saúde, tratamentos, agenda escolar, entre outros, também são obstruídas. O alienador marca atividades de que a criança gosta no horário de visita do outro genitor, por exemplo, diz que vai levar a criança para fazer compras no shopping ou tomar sorvete.

As mães podem escrever mensagens a seus ex-maridos aparentando ser muito cooperativas. Podem repassar os planejamentos das atividades das crianças, pedir informações dos filhos aos pais e afirmar serem dedicadas em promover boa relação entre genitor e filhos. No entanto, suas ações apontam no sentido oposto, pois não existe um acompanhamento até o fim de cada questão prática nas trocas de mensagens. Por exemplo, o pai pode reclamar sobre a falta de envio de informações médicas do filho pedindo sua atualização. A mãe faz uma resistência passiva, passa informações secundárias, incompletas ou infrequentes de forma que pareça que coopera, mas ainda assim o outro genitor continua sem poder acompanhar a evolução do tratamento nem participar das decisões e cuidados. 
Neste exemplo, uma mãe enviou email ao ex-marido suplicando-Ihe para ele mandar as datas de quando ele pegaria as crianças para passarem as férias com ele para que ela pudesse saber quando ela poderia ficar com os filhos durante o período de férias dela. No entanto, havia pouco tinham assinado um acordo que especificava as datas das férias de forma que a mensagem tinha intenção de encobrir suas manobras obstrucionistas e de exclusão, parecendo que ele evitava passar tais informações.

As visitas ao genitor alienado são dificultadas de diversas formas. Por exemplo, podem ser cumpridas com rigidez de horário. A criança não pode ser devolvida e retirada nem com cinco minutos de atraso. Se atrasar dez minutos, o genitor alienador já saiu com a criança. Outras formas de sabotar as visitas: mandar a criança sem roupa, sem uniforme, com roupas de outra estação ou deixar de mandar itens essenciais. Os objetos de que a criança gosta muito e traz da casa do alienado desaparecem.

Alguns programadores utilizam práticas religiosas fanáticas para doutrinar crianças e fazê-las opor-se ao outro genitor.

Outros utilizam o que Gardner chamou de tática dos nomes. O genitor alienador passa a referir-se ao outro genitor pelo primeiro nome ao invés de "mamãe" ou "papai", a criança passa a copiar e a chamá-lo pelo primeiro nome também.

Gardner menciona a tática da neutralidade que consiste na atitude do alienador em "respeitar a vontade das crianças de não ver o genitor", mantendo-se neutro no conflito e na recusa da criança uma vez que, segundo eles, o assunto não diz respeito a ele mas deve ser tratado entre alienado e filhos.

\subsubsection{Psicodinâmica do genitor alienador}


Gardner descreve alguns fatores psicodinâmicos operativos no genitor alienador que permitem identificar as razões da campanha do programador.

O autor aponta a manutenção do laço primário com a criança como o mais importante elemento que contribui na instalação da SAP. A possibilidade de ruptura, atenuação ou obstrução da relação do alienador com os filhos pode desencadear a patologia no intuito de preservação do vínculo ameaçado (este aspecto será desenvolvido no item 1.8).

O desprezo sentido após a separação pode ser mais um elemento que contribui para a patologia. Os genitores alegam infidelidade do parceiro ou abandono, mas, como não vivem diretamente com seus excônjuges, podem utilizar a criança para retaliação, privando o outro do contato com a prole. Da mesma forma, retaliações podem ser geradas a partir de questões econômicas. A perda do poder econômico após a separação ou a insatisfação com a divisão de bens podem gerar sentimentos de frustração e raiva.

A campanha de desmoralização pode surgir a partir de um mecanismo a reação formativa. Os resíduos da relação desfeita, o desejo, a admiração ou o amor, após a separação passam a ser suprimidos, podendo apenas ser expressos pela consciência em sua forma oposta, aparecendo como raiva e retaliação. A negação de um afeto ainda presente impede-o de ser expresso devido à ruptura do casamento, no entanto ele reaparece participando como fator contribuidor à instalação da SAP.

A projeção também pode ser tanto um elemento central como adjacente no processo da SAP. As acusações ao outro genitor podem servir para encobrir as próprias deficiências parentais de forma que as deficiências atribuídas ao alienado podem ser próprias de quem acusa. Assim, tendências e práticas atribuídas ao outro genitor revelam ser fruto de imaginação ou das próprias inclinações. Esse mecanismo também pode ser uma manobra de encobrir dificuldades parentais. 
Alguns genitores podem utilizar manobras excludentes, preparandose antes da separação para a futura disputa de guarda. A exclusão também pode ser presente durante todo o tempo da união do casal. $O$ ciúme dos filhos com o outro genitor, a competição com este e a hostilidade podem ser fatores que participam das manobras de exclusão na SAP.

Alguns genitores podem ser superprotetivos, no entanto utilizam essa característica como mecanismo para programar a SAP. O genitor alienador-protetor acredita que sempre está prevendo e evitando catástrofes, doenças e perigos com relação aos filhos. Sob discurso de amor, os filhos são proibidos de dormir na casa de outras pessoas, de sair de perto do genitor, de brincar livremente. Esse tipo de conduta parental pode gerar nos filhos Transtorno de Ansiedade de Separação definido no DSM. A superproteção também pode mascarar uma dependência do alienador em relação aos filhos.

A indução da SAP pode ser uma forma de aumentar a hostilidade para obter mais interação com o ex-cônjuge, mantendo assim o laço.

A vitimização, como elemento que participa da indução da SAP, tem intuito de gerar um senso mórbido de gratificação, como chamar atenção. O alienador gratifica-se de situações nas quais ele converte a si e ao filho em vítimas dos abusos do genitor alienado. Gardner desenvolve um extenso capítulo sobre alguns transtornos de personalidade que participam da psicodinâmica do alienador. Os padrões rígidos e persistentes de percepção do alienador acerca do ambiente, das relações sociais, permitem compreender as sutilezas da SAP e por que não são muitas vezes responsivos à terapia. Muitos apresentam manifestações de histeria, paranoia ou psicopatia. O prognóstico para aliviação dos sintomas são melhores quando as patologias de personalidade desencadearam-se com o litígio, não sendo, portanto, antigas. A Paranoia associa-se aos casos mais severos de SAP. O autor utiliza a noção de psicopatia no sentido de tendências psicopáticas. 
Além de fatores psicodinâmicos, alguns situacionais (ou externos) podem somar-se à psicodinâmica do genitor alienador e do filho. A SAP pode ser realizada por pais substitutos que criaram as crianças. Quando se veem afastados por algum motivo (separação, briga, mudança de cidade), podem iniciar uma programação. Um avô paterno criou as netas junto à mãe destas. Seu filho, o pai das meninas, trabalhava 14 horas por dia. Os pais se separaram, e anos depois a mãe mudou de cidade com as crianças. Na sequência, surgiu uma alegação de abuso sexual supostamente praticada pela mãe e denunciada pelo pai. Foi revelado que o avô paterno, com o qual o filho estava morando, conduzia a alienação para que tivesse as netas próximas novamente em sua casa.

As mudanças de cidade são apontadas como mais um fator externo no desenvolvimento da SAP. Uma mãe conheceu seu novo namorado em outro estado, porém o pai das crianças entrou com ação para impedir a mudança das crianças junto com a mãe. Ela passou a programar as filhas com vistas a ter vantagem no contexto processual. Neste caso específico, não fosse a mudança de cidade, a SAP não teria se desenvolvido.

Outros fatores são mencionados. A instauração de um processo de guarda pode desencadear a SAP. Gardner aponta o processo de guarda como poderoso fator por ser potencialmente diferente de outros tipos de processo, uma vez que enseja risco de ruptura dos laços dos filhos com o genitor. Deve-se considerar também, como fatores, o grau de persistência da programação e o grau das contribuições da criança/adolescente.

\subsection{O GENITOR ALIENADO}

\subsubsection{A Psicodinâmica do genitor alienado}

A teoria do autor enfatiza, conforme explicitado anteriormente, que o genitor alienado, apesar de participar da psicodinâmica da SAP, não pode ser apontado como responsável pela alienação da criança. No 
entanto, Gardner não nega que dificuldades psíquicas significativas do genitor, ou no âmbito de sua parentalidade, possam gerar a rejeição da criança. Em casos como esses, nos quais a rejeição pode estar ligada a causas justificáveis, o diagnóstico de SAP não se aplica. Na SAP, verificase que o grau de animosidade da criança não se correlaciona com pequenas problemáticas que possam surgir no campo da relação parentofilial.

... eu gostaria de enfatizar mais uma vez que os genitores alienados aos quais me refiro são os genitores realmente inocentes de qualquer comportamento que justifique o mérito do grau de animosidade deferida pelos filhos. (Gardner, 1998, p. 209)

Ao menos, para que possa ser diagnosticada a SAP, o genitor alienado deve ser um bom genitor, dedicado aos filhos, ter contato e envolvimento significativos com a criança antes da instalação da SAP. Na pior das hipóteses, apresenta pequenos defeitos de parentalidade que certamente não são suficientes para torná-lo totalmente alienado por seus filhos.

Dessa forma, os fatores psicodinâmicos e manifestações clínicas dos genitores alienados são secundários à importância do entendimento da psicodinâmica entre o par criança alienada-genitor alienador e na instalação da SAP.

Muito comumente, o fator intensidade da programação (não a programação em si, visto que esta é apontada como causa) feita pelo genitor alienador destaca-se como principal elemento contribuidor da SAP, o que permite mais uma vez afastar a participação do genitor alienado como causa da patologia:

Em alguns casos a programação pode ser mínima ou ausente, e o distúrbio resulta primariamente a partir de contribuições da criança. Em outros casos, fatores situacionais, podem ser importantes... Mais frequentemente, a eficácia do genitor alienador revela ser o fator predominante, além disso as contribuições da criança são desenvolvidas por ele. (Gardner, 1998, p.131)

Importante ressaltar que na SAP, apesar de o genitor alienador não ser um contribuidor à alienação, a força dos laços da criança com cada genitor determina o lado ao qual a criança se alinhará, bem como ajuda a 
determinar a resistência maior ou menor à alienação. Nesse sentido, a qualidade da vinculação da criança com o genitor alienado pode ser fator a amenizar a instalação da SAP e, dependendo da conjuntura de outros fatores, pode até mesmo evitar o desencadeamento da SAP.

\subsection{PROPOSTA INTERVENTIVA}

\subsubsection{Equipe de saúde mental}

O tratamento da SAP requer atuação conjunta de disciplinas para que se obtenham bons resultados. A proposta interventiva de Gardner combina abordagem da equipe de saúde mental, terapeutas e peritos, à intervenção dos Operadores do Direito, juízes e advogados.

O quadro 3 define as intervenções das equipes conforme o grau da SAP e conforme a maior ou menor tenacidade do programador em instalar a SAP. Ele oferece uma ideia genérica da forma de atuação dos profissionais apesar de Gardner descrever detalhes importantes não apresentados nela e comentar algumas exceções na forma de intervir, sendo assim, esse quadro não deve servir como orientação rígida.

Enquanto o papel dos peritos psicólogos se restringe a diagnosticar a SAP, para que os juízes possam intervir, o papel dos terapeutas revelase mais complexo.

Gardner propõe um trabalho terapêutico diferenciado com objetivo específico de desinstalar a SAP. O trabalho diferencia-se da técnica convencional terapêutica que é um trabalho psicológico profundo e de longa duração. Nessa proposta, não se trata de promover insights para revelar ao paciente a psicodinâmica subjacente à SAP. Trata-se de trabalhar a confrontação dos alienadores com o uso das crianças como instrumento de batalha, a confrontação da criança com os aspectos distorcidos da realidade acerca do genitor alienado e a sustentação de 
posição do alienado em face da retomada dos vínculos com os filhos, visando assim ao restabelecimento das visitas e da boa relação.

O profissional deve estar confortável com o papel autoritário e ativo, porque a terapia sem a determinação do juiz é inefetiva em razão da falta de cooperação dos genitores alienadores com o tratamento. $O$ tratamento funciona na medida em que o alienador inicialmente deve ser advertido de que a falta de cooperação com o tratamento será reportada ao juiz e de que, diante da não cooperação com o tratamento, as "ameaças" de reporte ao juiz podem gerar advertências ou sanções. Nesse sentido, o trabalho do profissional da saúde está diretamente atrelado ao judiciário, podendo ser definido como uma forma híbrida dos papéis de peritoterapeuta. $O$ autor refere que o termo terapia, para o trabalho com essas famílias, não descreve o papel do psicólogo, preferindo utilizar o termo dealing with.

Os atendimentos devem ser realizados apenas por um terapeuta para todos os membros da família nuclear. As sessões devem combinar atendimentos individuais e conjuntos (cada genitor separadamente com os filhos, entre os irmãos, entre os genitores, a família toda, entre outros envolvidos). Segundo o autor, a utilização de vários terapeutas para cada membro da família fraciona e reduz a comunicação na terapia, pois surgem subsistemas antagônicos que podem intensificar e promover as interações patológicas e contribuir para aumento da SAP.

$O$ aspecto de confidencialidade neste enquadre sofre modificação, pois o juiz poderá ser avisado sobre a evolução do tratamento e intervir com advertências e sanções. O terapeuta também pode revelar informações colhidas em entrevista com outros que não estavam presentes, caso esse procedimento seja significativo para o sucesso do tratamento. Mas as partes devem ser detalhadamente informadas quanto ao aspecto da confidencialidade.

O diagnóstico deve preceder o tratamento. O psicólogo inicialmente classifica o grau da SAP de acordo com o nível de alienação na criança (e não conforme o grau de programação praticada pelo alienador). Porém, o 
tratamento em si deve ser baseado na tenacidade do alienador, isto é, no prognóstico em descontinuar ou diminuir o nível de programação.

Em casos de alienação leve, geralmente não há necessidade de tratamento, pois uma decisão judicial que confirme a permanência da guarda da criança com o alienador traz a cura da SAP. A disputa de guarda ameaça, especialmente, a ruptura do laço com o genitor com o qual a criança possui vínculo psicológico mais forte, geralmente, as mães, que, como reação, passam a desenvolver a SAP.

Programadores no nível moderado ou severo geralmente recusam envolvimento com o tratamento. Se atestam algum interesse na participação, por outro lado, não cooperam, são obstrucionistas e sabotam a terapia. Não são candidatos ao insight terapêutico que os leve à razão de sua animosidade acentuada. No entanto, alguns genitores no nível moderado podem comprometer-se com a terapia.

No estágio moderado, a criança pode ter ataques de raiva durante a visita e não apenas no momento de transição, mais comuns no estágio leve. Apesar dos ataques, consegue voltar a relaxar e aproveitar a visita. O genitor alienado deve ser conduzido a desviar a criança dos ataques e provocações, evitando alongar-se nessas questões. Algumas acusações da criança devem ser questionadas, porém sem que se dedique tempo significante para não interferir no curso das visitas. O genitor pode pedir exemplos das experiências falsas que elas alegam e trazer boas experiências para serem contrapostas. Genitores alienados podem funcionar como um assistente ao terapeuta e ajudar a desprogramar a Síndrome. Como diferencial ao ambiente do alienador, o genitor deve permitir que a criança expresse tanto bons como maus sentimentos em relação a ambos os pais.

Na maioria de casos severos de SAP (5 a 10\%), a terapia torna-se impraticável. Os programadores severos não desistem da alienação ignorando ordens judiciais, uma das razões pelas quais se incluem na faixa de programação mais acentuada. A confrontação de sua opinião com a realidade revela-se impossível, pois muitos sofrem de distúrbios de 
paranoia. O terapeuta e o juiz são incorporados no sistema paranoide na medida em que não fazem alianças com a posição do alienador. O laço que se estabelece entre alienador e filho geralmente desvela um quadro de folie à deux, isto é, uma ligação patológica e diferente dos casos de alienação leve e moderada, nas quais no geral prevalece o vínculo psicológico saudável com o programador.

Em casos severos, não existe chance de manter a relação da criança com o genitor alienado e de aliviar os sintomas da criança, a menos que haja transferência de guarda para o genitor alienado. A criança com SAP severa não aceita ordem judicial e o genitor alienador não consegue incentivar de forma efetiva a criança para que ela vá às visitas. A criança tampouco pode ser fisicamente forçada a comparecer às visitas, pois pode ficar muito assustada e fugir por acreditar que o genitor seja perigoso.

A permanência da criança com SAP severa junto ao genitor programador significa o desenvolvimento de uma patologia e até mesmo paranoia, por isso Gardner sugere a inversão de guarda. Dada a gravidade da situação familiar nestes casos, a transferência não deve ser realizada diretamente. A única forma de transferência deve ser feita via um Programa de Transição de Residência Temporário.

O Programa de Transição de Residência apresenta três níveis de restrição e seis fases de adaptação. Os níveis do programa referem-se ao grau de restrição em termos de vigilância e de contato com os genitores, devendo sempre seguir a ordem do menos ao mais restrito, de acordo com o sucesso ou malogro do programa.

O programa consiste em seis fases de adaptação e tem o objetivo de facilitar a mudança de residência da criança. Cada fase pode durar alguns dias ou semanas. No entanto, o programa deixa de ser necessário quando a criança ainda estiver visitando o genitor. O terapeuta da SAP que tem acesso ao juiz monitora problemas e dificuldades que possam surgir, reportando-as a ele para intervenções necessárias.

A primeira fase resume-se aos primeiros dias subsequentes à mudança de residência da criança para a casa de um amigo ou parente 
dos genitores. Não deve haver contato dos filhos com o genitor alienador nem mesmo com o parente alienado. Pequenos contatos com o genitoralvo começam a acontecer dentro da casa transitória das crianças. Os contatos devem aumentar progressivamente em termos de frequência e duração.

$\mathrm{Na}$ segunda fase, a criança deve frequentar a casa do genitor alienado de forma progressiva até que passe a morar na casa deste, sua nova residência.

$\mathrm{Na}$ terceira fase, a criança passa a conviver com o genitor alienado, corrigindo sua percepção distorcida acerca dele, podendo ter boas experiências. Até esta etapa, contato algum com o genitor alienador deve ser permitido, pois regressões podem malograr o programa.

$\mathrm{Na}$ quarta fase, se houver boa convivência das crianças com o genitor-alvo e não ocorrerem tentativas de sabotagem da criança e do alienador ao programa, os primeiros contatos por telefone e email das crianças o com o genitor programador podem ser permitidos, porém monitorados.

$\mathrm{Na}$ quinta etapa, de acordo com o bom desenvolvimento do programa, os contatos das crianças poderão ser progressivamente expandidos até que o genitor alienador possa visitá-los na casa do genitor alienado.

Na sexta fase, as visitas das crianças à casa do genitor programador podem ocorrer desde que sua hostilidade ao alienado tenham diminuído. Em alguns casos, a última fase pode nunca ser alcançada em função de riscos maiores, por exemplo, sequestro da criança, entre outros. Nestes casos, as visitas sempre devem ser supervisionadas.

O programa também prevê três níveis de restrição. No primeiro, a criança muda-se temporariamente para a casa de um terceiro neutro. Se a criança burlar o programa, isto é, se continuar resistindo às regras e apresentar um comportamento incontrolável e se o alienador tomar atitudes no sentido de sabotar o programa, deve-se passar ao segundo nível do programa. Neste aloca-se a criança em um abrigo em razão da 
maior vigilância. Se ainda assim este nível falhar, o terceiro nível deve ser aplicado internando a criança em hospital psiquiátrico.

Cada dinâmica familiar deve ter uma estratégia específica de atuação profissional. Os filhos mais velhos podem desempenhar o papel do alienador e programar os irmãos mais novos, por exemplo, levando-os a desrespeitar o genitor ou a crer que ele seja perigoso. Quando este tipo de dinâmica estiver presente, o terapeuta deve indicar ao juiz que determine visitas separadas de cada criança. Também podem existir diferentes níveis de alienação entre as crianças, um filho alienado e o outro não, ou ainda um filho alienado pela mãe; enquanto o outro é alienado pelo pai.

\subsubsection{Operadores do Direito: advogados e juízes}

Quanto à abordagem jurídica especificamente, o autor afirma que a redução da programação na criança depende em grande parte da ordem judicial, sem ela torna-se inefetiva. O quadro 3 traz os passos necessários à intervenção e os planos alternativos caso não se obtenha bons resultados.

Uma das premissas mais básicas defendidas pelo autor é a prevenção da SAP. Apesar de parecer contrária a suas ideias, para prevenir ou diminuir a probabilidade de um dos genitores induzir a SAP e de a criança desenvolvê-la, a guarda deve ser deferida ao genitor segundo critério da presunção do vínculo psicológico mais forte e saudável. Para o autor, "o forte laço que se forma nos primeiros anos de vida entre a criança e o genitor primário produz uma imensa fixação de um pelo outro quando ameaçado o rompimento da relação" (Gardner, 1998, p. 374).

Dessa forma sua visão da patologia relacional está ligada ao contexto do litígio pois se instala quase exclusivamente em resposta à possibilidade da perda de guarda. O genitor instala a SAP para sabotar a tentativa de o outro genitor obter a guarda, e a criança contribui com a 
alienação por receio de afastar-se deste genitor. A respeito do genitor mais vinculado à criança, Gardner (1998) enfatiza:

Da mesma forma que a criança sofre psicologicamente quando retirada do genitor, o adulto fica traumatizado pela retirada da criança. O trauma psicológico causado por essa disrupção pode ser enorme, de tal forma que a capacidade de parentalidade pode ficar prejudicada. (p. 374)

Este critério de atribuição de guarda defendido pelo autor (o vínculo psicológico mais forte e saudável) consiste em um balanço no qual se verifica qual genitor realizou os cuidados primários nos anos iniciais da criança, qual genitor desenvolveu maior vinculação ao longo a vida da criança e também se existe um intervalo de convivência com um dos genitores e qual o tempo dele. Ao mesmo tempo, Gardner afirma que genitores que induzem a SAP possuem deficiências parentais uma vez que praticam um tipo de abuso emocional infantil. Essas deficiências devem ser um dos fatores a serem levados em consideração na disputa de guarda, inclusive deve-se considerar a hipótese de o alienador apresentar outras dificuldades parentais não associadas à programação.

Nesta visão, naturalmente muitas guardas seriam concedidas às mães, pois geralmente elas realizam a maior parte dos cuidados com os filhos ao longo da vida e possuem maior vinculação. Mas, de acordo com o critério defendido pelo autor, pais também poderiam obter a guarda se satisfizessem o mesmo critério, por exemplo, casos de pais que oferecem grandes contribuições para criação dos filhos ao passo que a contribuição da mãe pode ser menor ou de alguma forma comprometida.

No entanto, apesar de enfatizar o surgimento da SAP a partir da disputa de guarda, o autor reconhece outros fatores (que serão tratados mais à frente) desencadeantes que não apenas uma ação judicial que ameace a ruptura do vínculo. Ainda pode-se verificar por vezes que, mesmo quando concedida a guarda ao genitor alienador, a SAP não regride.

O deferimento de guarda em situações de mudança de cidade deve ser atentamente examinado nos processos em geral. As razões para 
mudança repentina de cidade podem ensejar uma tentativa de o genitor retirar-se da cena de conflito ou fazer uma manobra de exclusão que mais tarde pode vir a revelar-se a tentativa de instalar a SAP. De acordo com Gardner (1998, p. 325), "a presença de SAP fornece mais apoio ao sistema judicial para impedir mudanças de guarda".

Para determinar a intervenção mais adequada, inicialmente o Juiz deve verificar a gravidade da SAP por meio dos sintomas apresentados pela criança. Em segundo lugar, verificar se existe chance de a programação cessar ou se deve ser considerada a possibilidade de inversão de guarda.

Quanto mais tenaz a programação e mais resistente o alienador à intervenção terapêutica, mais pobre será o prognóstico para mudanças e maior a probabilidade de inversão de guarda... geralmente em casos de SAP moderada (às vezes até mesmo em casos leves), o juiz deve considerar a mudança de guarda em razão do pobre diagnóstico para mudanças no programador e do alto risco de a criança deslocar-se rapidamente para o nível severo da SAP, se não for protegida do alienador. (Gardner, 1998, p. 377)

No entanto, como regra geral em casos leves de SAP, o juiz tem maior poder do que os terapeutas especializados, pois a determinação da guarda em favor do alienador tem grande chance de reverter a SAP. Neste nível não se prevê a proposta de terapia para SAP, pois

Os sintomas, tanto na mãe como na criança, frequentemente devem desaparecer (muitas vezes de forma dramática) assim que o juiz determina que a criança deve permanecer com a mãe. (Gardner, 1998, p. 378)

No entanto, neste nível, as medidas judiciais em relação à SAP podem ser efetivas fazendo regredir a programação. Quando o genitor programador apresenta um alto grau de persistência, as sanções se revelam ineficazes para cessar esse processo. Então deve ser considerada a inversão de guarda em favor do outro genitor. Devdeve-se frisar que, para Gardner, os genitores alienados que recebem a guarda dos filhos devem ter boa capacidade de parentalidade e envolvimento significante com seus filhos antes da separação. Também não devem ter dificuldades parentais que justifiquem hostilidade ou a recusa de contato dos filhos. 
Em casos de SAP moderada, o juiz deve primeiramente adotar o plano A: a decisão de guarda em favor do alienador pode desinstalar a SAP. Caso contrário, o terapeuta da SAP atrelado ao judiciário deve ser nomeado. $O$ juiz deve informar no processo todas as partes que devem participar da terapia, inclusive partes significantes envolvidas na perpetuação da alienação. Além de tratar a família, o terapeuta deve monitorar as visitas e reportar ao juiz as dificuldades e falhas na visitação.

Em segundo plano, parte-se para as advertências com intuito de fazer regredir a SAP. As advertências e sanções fazem-se necessárias na medida em que alguns genitores não são candidatos a terapia. Os alienadores primeiramente devem ser advertidos pelo juiz de que a obstrução das visitas acarretará sanções. Advertências devem lembrar o alienador de que deve cooperar com as visitas, que podem ajudar na regressão da alienação. Tais advertências podem surtir efeitos nas crianças, pois as ajudam a aliviar a culpa por desejarem visitar o genitoralvo. A dificuldade das crianças em assumirem para o alienador o afeto pelo outro genitor pode ser substituída pela justificativa de serem obrigadas a realizar as visitas.

Nos momentos de transição, por serem momentos nos quais os conflitos de lealdade aparecem aumentados, os sintomas da SAP da mesma forma surgem mais intensos. Por esse motivo, deve-se evitar que as crianças sejam pegas na casa do programador, uma vez que sua presença fará com que resistam ao outro genitor. Os arranjos alternativos de transição evitam a confrontação da criança com ambos os pais por meio de um terceiro imparcial, das escolas ou do consultório do terapeuta. O psicólogo pode fazer o monitoramento empírico desses momentos pois suas observações são mais fidedignas do que o relato verbal das partes.

Caso falhem as advertências, deve-se aplicar o primeiro nível de sanção e ir progredindo conforme o alienador se recusar a recuar. Crianças com SAP necessitam de desculpas para visitar o genitor vitimizado. O juiz pode servir a criança nessa função. A criança pode utilizar racionalizações do tipo: Eu odeio meu pai, mas o juiz me obriga a 
vê-lo, Eu preciso ir às visitas para ele dar dinheiro para nós ou Apenas vou lá porque gosto de brincar com o cachorro. Elas desejam visitar o genitor, mas precisam de uma desculpa para fazê-lo. Essas racionalizações ajudam-nas a convencer o programador a aprovar suas visitas. O genitor alienador também pode fazer com que a criança visite 0 outro genitor para não sofrer sanções. Resumindo: tanto o alienador como a criança são responsivos às sanções.

Geralmente, o plano A não sucede quando a campanha de alienação tiver sido mais prolongada ou quando o programador for muito resistente às mudanças. Dessa forma, as resistências à visitação se manterão, sendo necessário adotar o plano $\mathrm{B}$.

O plano B geralmente é aplicado em casos de crianças com nível moderado de SAP, que têm genitores fanáticos ou obcecados e não passíveis de tratamento psicológico. Nesses casos, as sanções também se tornam inefetivas e a falta de ação pode levar a criança a atingir o nível severo de SAP. Nestes casos, adota-se o plano B: a guarda deve ser invertida e a visitação do genitor deve ser restringida de acordo com as características do caso, podendo até mesmo ser supervisionada.

Em casos severos de SAP, a criança atinge esse nível de alienação, pois os genitores são fanáticos e estabelecem um laço patológico com seus filhos. As ordens judiciais são impotentes para cessar a alienação. A guarda deve ser transferida aos genitores alienados. No entanto, cabe destacar um ponto importante na obra do autor:

...os genitores vilipendiados a que me refiro aqui são aqueles que têm razoavelmente uma boa relação com seus filhos antes da disputa judicial e que, apesar de terem algumas dificuldades, são muito mais saudáveis do que os genitores programadores. (Gardner, 1998, p. 382)

Nestes casos, a permanência da criança com os genitor alienador representará o desenvolvimento de psicopatologia ou até mesmo de um quadro de paranoia. Mais além, a inversão de guarda é a única forma de o filho manter a relação com o outro genitor. 
Contudo, as crianças nesse estágio da SAP não cooperam voluntariamente com a ordem judicial de mudança de guarda, porque os alienadores não conseguem consentir com a ordem judicial. Assim, a mudança direta de residência torna-se impraticável. Deve-se adotar o Programa de Transferência de Residência Temporário para diminuir a resistência da criança à mudança. O programa visa remediar a confrontação da criança com ambos os genitores no mesmo período.

$\mathrm{O}$ autor critica algumas ordens judiciais apontadas como ingênuas ou inefetivas. Juízes ordenam tratamento psicológico ao alienador com muita facilidade. Acreditam poder ordenar que uma pessoa se trate na terapia com convicção e compromisso. Se por um lado ela pode ser indicada para o genitor programador, por outro pode ser utilizada como manobra de protelação do processo. Outras ordens específicas para que o genitor pare de programar, como proibir os pais de falarem mal uns dos outros ou proibir de falarem sobre o divórcio, mostram-se impotentes visto que a comunicação não verbal e as formas de depreciação mais poderosas são sutis, e a ordem judicial não consegue preveni-las. $O$ juiz tampouco tem o poder de evitar que a criança saiba dos conflitos que cercam a separação. Além de perguntar, a criança está, muitas vezes, neles inserida.

Muitos juízes protelam decisões por terem dificuldade em tomá-las de forma que acabam por beneficiar o alienador já que o fator tempo revela-se crucial no sucesso em instalar a SAP. Com relação aos magistrados: "Eles constantemente acham desculpas para continuar protelando a decisão final. Alguns fazem ameaças de sanções contra o genitor alienador não cooperativo, mas nunca as executam" (Gardner, 1998 , p. 383). Ainda nesse sentido: "... quanto mais se estender a litigância, menor as chances de o tratamento ter sucesso" (Gardner, 1998, p. 337), e a ordem judicial será menos efetiva. Decisões rápidas com objetivo de impedir o aprofundamento da Síndrome podem evitar rupturas irreversíveis, pois o laço psicológico forte e saudável com o genitor 
alienado "serve como antídoto ao desenvolvimento de uma forma mais severa de SAP na criança" (Gardner, 1998, p. 326).

Da mesma forma, o autor também discute as implicações dos trabalhos dos advogados que ajudam a perpetuar essa forma de violência infantil. De acordo com as doutrinas legais, eticamente o advogado deve sustentar a posição do cliente. Dessa forma, Gardner questiona a ética do advogado que defende o genitor alienador por apoiar suas atitudes destrutivas. Esse apoio induz ao aumento da patologia e/ou da violência familiar, consequentemente prejudica a criança. Alguns advogados até mesmo participam do delírio paranoide do cliente trazendo enorme prejuízo a toda a família. Ao decidir representar o programador e sustentar sua posição obstrucionista, a convicção do advogado pela posição do cliente deixa de ser um fator operativo em seu trabalho. Se o profissional não sustentar os pedidos do cliente, existe grande chance de não ser contratado. Assim, muitos profissionais criam dissociações em seu trabalho, isto é, racionalizações para justificar os pedidos que fazem no processo ao passo, servindo o cliente de forma não ética.

Por outro lado, os advogados do genitor alienado devem agir rapidamente para obter uma ordem apropriada, pois o fator tempo em casos de alienação é uma das armas mais efetivas do genitor alienador. Contrariamente a este ponto, alguns advogados trabalham sobre o princípio de que, quanto mais prolongado o litígio, maior o ganho financeiro; outros são pouco acessíveis ao cliente e outros muitas vezes não entendem especificamente da patologia em questão. O autor aponta que questões como estas podem prejudicar a agilidade no processo trazendo consequências iatrogênicas para a família.

O autor também discute consequências na saúde mental das partes, produzidas a partir de uma forma problemática do funcionamento do sistema judiciário. Os advogados podem apreciar o uso do sistema adversarial para postergar o litígio, mas com isso podem ensejar riscos às crianças quando não há, aumentar eventos e ocorridos, dramatizar, 
manifestar reações exageradas, gerando aumento de sentimento de persecutoriedade.

\begin{tabular}{|c|c|c|c|}
\hline & LEVE & MODERADA & SEVERA \\
\hline $\begin{array}{l}\text { ABORDAGEM } \\
\text { LEGAL }\end{array}$ & $\begin{array}{l}\text { Decisão judicial de } \\
\text { guarda unilateral } \\
\text { para o genitor } \\
\text { alienador }\end{array}$ & $\begin{array}{l}\text { Plano A } \\
\text { (mais comum) } \\
\text { 1. Decisão judicial } \\
\text { de guarda unilateral } \\
\text { para o genitor } \\
\text { alienador } \\
\text { 2. Nomeação do } \\
\text { terapeuta de SAP } \\
\text { 3. Sanção } \\
\text { a.Dinheiro } \\
\text { b.Prisão } \\
\text { domiciliar } \\
\text { c.Prisão } \\
\qquad \begin{array}{l}\text { Plano B } \\
\text { necessário) }\end{array} \\
\text { (ocasionalmente, se } \\
\text { 1. Decisão judicial } \\
\text { de transferência de } \\
\text { guarda ao genitor } \\
\text { alienado } \\
\text { 2. Restrições de } \\
\text { visitas do genitor } \\
\text { alienador, sob } \\
\text { supervisão, se } \\
\text { necessário, para } \\
\text { prevenir } \\
\text { programação }\end{array}$ & $\begin{array}{l}\text { 1. Transferência de } \\
\text { guarda unilateral ao } \\
\text { genitor alienado (na } \\
\text { maioria dos casos) } \\
\text { 2. Decisão judicial } \\
\text { de programa de } \\
\text { transição de } \\
\text { residência }\end{array}$ \\
\hline $\begin{array}{c}\text { ABORDAGEM } \\
\text { PSICOTERAPÊUTICA }\end{array}$ & $\begin{array}{l}\text { Normalmente } \\
\text { nenhuma é } \\
\text { necessária }\end{array}$ & $\begin{array}{c}\text { Plano A } \\
\text { (mais comum) } \\
\text { Tratamento pelo } \\
\text { terapeuta de SAP } \\
\text { nomeado } \\
\cdot \cdot \\
\text { Plano B } \\
\text { (ocasionalmente, se } \\
\text { necessário) } \\
\text { Programa de } \\
\text { transição de } \\
\text { residência } \\
\text { monitorado }\end{array}$ & $\begin{array}{l}\text { Programa de } \\
\text { transição de } \\
\text { residência } \\
\text { monitorado pelo } \\
\text { terapeuta }\end{array}$ \\
\hline
\end{tabular}

Quadro 3 - Tratamento diferencial dos três tipos de Síndrome de Alienação Parental 


\section{ALIENAÇÃO PARENTAL NO DIREITO BRASILEIRO}

Com o advento da nova Lei brasileira $12.318 / 10$ que dispõe sobre a alienação parental, somos chamados a refletir sobre o impacto do tema no trabalho dos Operadores do Direito - advogados, promotores, juízes e desembargadores. Curiosamente, a Lei introduz uma definição jurídica acerca de termo consagrado em outra área de saber, a psiquiatria. Por ser um tema comum a duas áreas distintas, busca-se, neste trabalho, discutir como os profissionais vêm lidando na práxis com o tema, as produções acadêmicas, as decisões judiciais em primeira instância e do Tribunal bem como tecer comentários sobre a Lei.

Importante trazer para a discussão os dois termos utilizados na Lei brasileira (atos de AP e alienação parental) e ao mesmo tempo comparar com o conceito original - cunhado em 1985 pelo psiquiatra forense norteamericano Richard Alan Gardner -, de onde foi emprestada, ainda que parcialmente, a denominação da Lei. Não há que se tomar um termo pelo outro, já que a Lei não equivale à teoria de Gardner. Evitam-se, assim, equívocos que podem ser gerados devido à sobreposição dos campos - a Psiquiatria/Psicologia e o Direito. Estabelecer aproximações e diferenças entre as duas definições passa a ser importante tarefa dos Operadores do Direito para uma intervenção mais precisa que impeça mais distorções e confusões.

Em termos gerais, a Lei tem a finalidade de tornar mais efetivo os direitos fundamentais da criança e o exercício do poder familiar de ambos os genitores após a separação conjugal. Cabe uma observação quanto ao termo "após a separação", pois não existe esta menção na Lei. Ou seja, não há necessidade de haver uma dissolução jurídica de união para configurar-se a AP. Ela pode surgir a partir do divórcio ou da separação, e em outras situações ou rompimentos, por exemplo, um namoro, uma relação breve. Também pode surgir em situações familiares não relativas à separação, como quando existem outros responsáveis pela criança. Para essa regulação, a Lei estabelece alguns critérios específicos sobre os 
direitos das crianças e dos pais que, quando não respeitados, implicam medidas judiciais protetivas, que podem ser coercivas, como multa, advertência, tratamento psicológico, aumento da convivência da criança com o outro genitor, inversão de guarda e suspensão do poder familiar. Sobre a definição de alienação parental na Lei:

Art. $2^{\circ}$. Considera-se ato de alienação parental a interferência na formação psicológica da criança ou do adolescente promovida ou induzida por um dos genitores, pelos avós ou pelos que tenham a criança ou adolescente sob a sua autoridade, guarda ou vigilância para que repudie genitor ou que cause prejuízo ao estabelecimento ou à manutenção de vínculos com este.

$\mathrm{Na}$ definição, trata-se mais de uma demarcação jurídica do que propriamente psicológica. Por exemplo, a partir da idade de 18 anos, o jovem torna-se maior responsável, não havendo mais o reconhecimento jurídico de alienação parental, o que não significa que o abuso do genitor ou o processo psíquico de alienação no jovem deixe de existir do dia para noite. Também não se englobam na definição jurídica da Lei noções de dinâmica familiar, patologia psíquica do genitor ou da criança, tais como descritas na literatura psiquiátrica ou psicológica sobre SAP ou AP. Tampouco se utiliza o termo síndrome, uma vez que ele tem atraído críticas ferozes, consistentes ou não.

Encontramos na Lei 12.318 dois termos - atos de alienação parental e alienação parental. Assim deve-se frisar que a Lei brasileira inaugurou um segundo conceito específico para alienação parental - atos de alienação parental -, nuança não observada por alguns profissionais. Essa não observância tem trazido efeitos interferindo na práxis, uma vez que a definição brasileira difere de forma significativa do conceito criado por Gardner.

Os atos de alienação parental são atos isolados, exemplificados no rol da lei, ou outros atos, determinados pelo juiz ou pela perícia, (art. 20, parágrafo único), que cumpram com o fito de afastar o convívio dos filhos com o genitor, desqualificar a imagem deste e/ou dificultar o exercício do poder familiar. 
Importante a observação quanto aos termos, visto que não há necessidade de caracterizar alienação parental como problemática psicológica para que a Lei seja aplicada; atos isolados também podem receber sua aplicação. Segundo o art. $6^{\circ}$ da Lei: "... caracterizados atos típicos de alienação parental ou qualquer conduta que dificulte a convivência da criança ou adolescente com o genitor..." (grifo nosso). Assim, dispensa-se a caracterização psicológica, patológica ou subjetiva, visto que tais atos, por si sós, afetam os direitos fundamentais das crianças e dos adolescentes (art. $3^{\circ}$ ). De acordo com o art. $3^{\circ}$ :

A prática de ato de alienação parental fere o direito fundamental da criança ou do adolescente de convivência familiar saudável, prejudica a realização de afeto nas relações com genitor e com o grupo familiar, constitui abuso moral contra a criança ou o adolescente e descumprimento dos deveres inerentes à autoridade parental ou decorrentes de tutela ou guarda.

Por outro lado, a abordagem teórica e prática proposta por Gardner (1998) versa sobre uma configuração específica de alienação, sobre um distúrbio da criança. O que caracteriza sua definição é o formato de campanha de desmoralização feita pela criança e não pelo genitor alienador. Quando existe um genitor alienador sem a instalação de SAP na criança, deve-se utilizar o termo programação, mas não se aplica o diagnóstico de SAP. Portanto, sem a contribuição da criança para a missão desmoralizadora do alienador, não se aplica o diagnóstico de SAP nem a abordagem interventiva de seu criador.

Numa comparação entre as definições de Gardner e a Lei brasileira, nesta última observa-se uma ampliação da definição de alienação parental quando comparada com a definição de SAP, pois atos isolados de AP são coibidos pela Lei; também não há menção à palavra síndrome. Não há, portanto, necessidade de que a criança passe a rejeitar o genitor, desenvolva uma SAP, para que medidas judiciais sejam cabíveis. Nem que exista um genitor programador, isto é, que a depreciação seja feita em formato de campanha. Este é o caso da abordagem de Gardner, somente aplicável diante do somatório de dois elementos - a presença de um programador e da criança já alienada. 
Segundo o juiz do Trabalho Elizio Luiz Perez (2010), autor do anteprojeto de Lei, a definição desta envolve primeiramente um caráter preventivo da alienação. Não existe necessidade de instalar a SAP, isto é, de a criança passar a rejeitar o genitor para se tomarem providências legais. A sanção versa sobre as atitudes do genitor que pratica tais atos, sendo ele um programador ou não, havendo SAP ou não:

Independentemente da presença da Síndrome da Alienação Parental (SAP) ou de consequências outras, constata-se que o processo psicológico de alienação parental representa, ele próprio, forma de abuso emocional contra a criança ou adolescente. Eis o primeiro ponto a que a lei se voltou: evitar, na origem, a prática de tal modalidade de abuso, dando visibilidade ao contexto em que praticado e os riscos a ele inerentes, ainda que não se infira dele necessário distúrbio para a criança ou adolescente. (p.68)

Mais adiante (2010):

Tal motivação do projeto de origem, de natureza preventiva, afasta a situação prática absurda de se ter de aguardar a implementação de iminente prejuízo à criança para se permitir intervenção. Não se trata de faculdade do Estado pronunciar tais lesões e atuar em denúncias de abuso (ou ameaça de), ainda que de natureza psíquica. (p.69)

No mesmo sentido preventivo aponta Fonseca (n.d). O judiciário deve intervir diante da instalação da síndrome de alienação parental na criança, e também antes desta, quando se verificam atitudes alienadoras por parte de um dos genitores, o que a autora nomeia como alienação parental:

Uma vez identificado o processo de alienação parental, é importante que o Poder Judiciário aborte o seu desenvolvimento, impedindo, dessa forma, que a síndrome venha a se instalar.

Via de regra, até por falta de adequada formação, os juízes de família fazem vistas grossas a situações que, se examinadas com um pouco mais de cautela, não se converteriam em exemplos do distúrbio ora analisado. (grifo nosso)

A definição de Fonseca para alienação parental diz respeito às atitudes do alienador, equivalendo ao conceito de programação de Gardner. Para este, diferentemente, o termo alienação parental define-se não pelas atitudes dos pais, mas pela atitude da criança em rejeitar o genitor.Porém somente se aplica diagnóstico de AP (não de SAP), quando 
existem motivos reais ou justificáveis para a rejeição da criança, por exemplo, quando ela foi abusada sexualmente. Observa-se que a expressão alienação parental é utilizada de formas diametralmente opostas por Fonseca e Gardner. No entanto, nos EUA, os pós-gardnerianos passaram a utilizar o termo AP no lugar de SAP em razão das críticas que o termo síndrome atraiu. Neste exemplo, Douglas Darnall (1998) utiliza o termo AP de forma semelhante à teoria da SAP, mas deixa claro uma construção teórica própria e diferente da obra de Gardner.

Observa-se que, em parte dos processos litigiosos de separação, não há instalação de SAP na criança nem presença de genitor programador conforme descrito por Gardner. Não há necessidade de constituir-se uma SAP ou de haver um genitor programador para atitudes serem caracterizadas como atos de alienação parental. Enquanto a definição de "atos" amplifica o que se entende por alienação parental, o modelo de Gardner patologiza essas situações, pois inclui casos mais graves de obstaculização ligados a problemáticas importantes do genitor alienador e à violência psicológica.

Uma observação que não pode deixar de ser analisada deve-se às consequências da ampla definição da Lei. De acordo com a definição gardneriana, dois genitores podem fomentar a SAP, mas apenas um consegue instalá-la, pois ela representa o alinhamento da criança a um dos lados. Nesta abordagem, somente um genitor deve ser responsabilizado pelo abuso e pela patologia na criança. Porém, não raro, ambos os pais cometem atos de alienação parental, visto que tais atitudes isoladas são usuais em litígio. A Lei brasileira, por basear-se nas atitudes do alienador, abre a amplitude quanto a sua aplicação. Por não se tratar especificamente da SAP, considera a possibilidade de os dois genitores praticarem AP; podendo, portanto, recaírem sanções sobre ambos ou mais responsáveis.

Decisões em primeira instância no Estado de São Paulo apontam os dois genitores como possíveis alienadores, lançando advertência a ambos. 
Decisão publicada no Diário Oficial do Estado de São Paulo do dia 17/05/2011, página 1121, é exemplo disso:

082.01.2009.002078-5/000000-000 - no ordem 179/2009 - Regulamentação de Visitas - R. C. D. C. X D. B. S. - AG 63 - Vistos. Por ora, entendo que não é o momento de encerrar o processo. O direito de visitas não é apenas um direito do genitor, sendo também um direito da criança. Pelos relatos do Conselho, bem como pelo relato técnico, essa Magistrada observa a intensa animosidade existente entre as partes. Nada obstante, a animosidade existente entre as partes não poderá refletir na criança e no seu desenvolvimento. Ademais, é extremamente provável que as partes incidam no ato de alienação parental. Por outro lado, o intenso desequilíbrio emocional de ambas as partes não pode prejudicar as visitas da criança. Determino que o autor e a requerida sejam encaminhados para tratamento psicológico neste município, oficializando-se a Secretária de Saúde do município para encaminhamento. Saliento que o início do tratamento deverá ser noticiado nestes autos, adicionando o nome do profissional. Int. - ADV FERNANDA ANDREZA SILVA MARQUES OAB/SP 203086 - ADV KARINE MARIA SOARES ZANOTTO OAB/SP 246164 - ADV SELY MARIA MENDES DO AMARAL BERTHO OAB/SP 84190 - ADV VERA APARECIDA CARVALHO DE OLIVEIRA OAB/SP 275244. (grifo nosso)

Também se encontram advertências a diversos familiares, que atuam conjuntamente aos pais alienadores, por exemplo, decisão no Diário Oficial de São Paulo do dia 18/02/2011, página 176.

3653/09 - GUARDA DE MENOR - Movida por A. C. F. em face de C. R. D. M. fls.141: Como muito bem salientou o ilustre representante do Ministério Público, não me parece adequada a transferência da guarda da criança, por dois meses, para a realização do estudo social sem a influência da família paterna até poderia ser mais proveito [sic]; porém, não considero razoável a modificação abrupta da guarda, mesmo que o objetivo seja uma avaliação mais aprofundada. A medida é extrema e não se mostra proporcional ao objetivo perseguido. Por outro lado, o genitor e a avó paterna da menor devem estar cientes da gravidade da conduta de afastar deliberadamente a criança de sua genitora. Atualmente, de acordo com a lei 12318/2010, considera-se ato de alienação parental a influência na formação psicológica da criança, promovida ou induzida pelos genitores ou avós. Caracterizada a existência de atos típicos de alienação parental ou qualquer conduta que dificulte a convivência do menor com o genitor, o magistrado poderá, sem prejuízo da decorrente responsabilidade civil ou criminal, tomar uma das medidas explicitadas no artigo $6^{\circ}$ da supra-citada e, dentre as quais determinar alteração da guarda e até declarar a suspensão da autoridade parental. Não estamos ainda concluindo pela existência de atos típicos de alienação parental; porém, de acordo com o parecer parcial do setor técnico (fls. 127/128), há indícios nesse sentido. Sendo assim, o requerente e sua genitora (avó paterna da menor) deverão estar cientes da importância de não obstarem a convivência entre mãe e filha. Neste mesmo sentido, deverão levar Ana Julia até a residência de sua mãe, no dia 19 de janeiro, para realização do estudo social. Int. Adv.: (61567/SP) MARIA DO CARMO DA SILVA RODRIGUES, (91953/SP)JOSE ANTONIO VIEIRA ALVES 3973/09 - EXONERACAO DE PENSAO - Movida por S. D. P. em face de E. D. S. P., L. D. S. P., E OUTROS - fls.61: Retifico. (grifo nosso) 
Se por um lado a definição da Lei acentua questões menores de alienação realizando assim uma prevenção; por outro, engloba situações familiares menos conflituosas e que podem surtir bons resultados com outras intervenções que não apenas jurídicas, como mediação, tratamento psicológico, entre outras. Esta nuança deve ser observada pelos profissionais ao atuarem, em vez de entenderem que a medida mais radical é adequada em todo e qualquer caso. Existem diferentes tipos e intensidades de alienação, o que não deve escapar à compreensão dos profissionais jurídicos.

A definição da Lei sobre AP, por ser ampla, pode incentivar o uso generalizado pelos advogados no sistema judicial como instrumento de empoderamento, barganha ou ameaça. No entanto cabe aos magistrados e promotores, através de sua atuação, o controle do uso descomedido. Para Fonseca (s.n.), cabe também imputar responsabilidade aos advogados quando procurados por um genitor alienador:

Patenteado o processo de alienação parental promovido pelo progenitor alienante, não se permite aos advogados, em nome de uma suposta defesa de seus direitos, prejudicar aquele que é, em tais casos, o interesse maior a ser protegido: o do menor.

A atuação do advogado pode resultar na condenação do cliente por litigância de má-fé em casos de alienação parental quando objetiva forjar acusações e provas para afastar a criança do genitor. Assim entende-se a partir da decisão publicada no Diário oficial do Estado de São Paulo de dia 31/05/2011, página 3501:

177.01.2010.003141-6/000000-000 - no ordem 1746/2010 - Medida Cautelar (em geral) - C. A. V. M. O. X J. F. S. - Fls. 83 - C O N C L U S Ã O Em 24/05/2011, faço estes autos conclusos ao (a) MM. Juiz (a) de Direito Dr. (a). Patrícia Padilha Assumpção. Eu, (Selma Martins Reis - 813.087-F), escr. Proc. $1746 / 10$ Vistos 1. Rejeito alegação de carência da ação (fls.61), pois o pedido é juridicamente possível. 2. Assiste razão o Ministério Público, ação que versam [sic] sobre guarda não fazem [sic] coisa julgada material. Assim, surgindo fato novo e nova causa de pedir, logo, rejeito a preliminar de coisa julgada (litispendência). 3. Por fim, a inicial é apta, destacando que, se os fatos narrados forem absolutamente inverídicos, responderá por litigância de má fé e eventual alienação parental. 4. Ao Setor Social. Int. - ADV SILVIA REGINA CASSIANO OAB/SP 206841 - ADV KARINA FERNANDA DE PAULA OAB/SP 214344. (grifo nosso) 
Anteriormente ao advento da Lei que dispõe sobre alienação parental, a legislação brasileira já previa instrumentos para aplicar as medidas previstas pela primeira. O direito a convivência familiar e a proteção quanto a situações de violência, opressão, crueldade, comumente observadas na AP, são previstos no ECA e na Constituição Federal. O ECA, Lei 8.069, no art. 19, reafirma o direito da criança e do adolescente "a ser criado e educado no seio da sua família". E de acordo com a Constituição Federal:

Art. 227. É dever da família, da sociedade e do Estado assegurar à criança, ao adolescente e ao jovem, com absoluta prioridade, o direito à vida, à saúde, à alimentação, à educação, ao lazer, à profissionalização, à cultura, à dignidade, ao respeito, à liberdade e à convivência familiar e comunitária, além de colocá-los a salvo de toda forma de negligência, discriminação, exploração, violência, crueldade e opressão. (grifo nosso)

Coaduna-se a estes o Código Civil, Lei 1.046, que determina que, com a separação ou divórcio dos pais, o poder familiar mantém-se inalterado, sendo ainda assegurada a convivência entre pais e filhos:

Art. 1.632. A separação judicial, o divórcio e a dissolução da união estável não alteram as relações entre pais e filhos senão quanto ao direito, que aos primeiros cabe, de terem em sua companhia os segundos.

Art. 1.589. O pai ou a mãe, em cuja guarda não estejam os filhos, poderá visitálos e tê-los em sua companhia, segundo o que acordar com o outro cônjuge, ou for fixado pelo juiz, bem como fiscalizar sua manutenção e educação.

Segundo o Código Civil, o instituto do poder familiar compreende uma série de funções e obrigações a serem exercidas por parte de ambos os pais, como participar da educação dos filhos e tê-los em sua companhia. Este direito garantido mormente é afetado no pós-divórcio quando incide a alienação parental e o guardião alienador passa a exercer autoritariamente o poder familiar.

Segundo Simão (2008), a alienação parental que pode ser configurada por obstaculizar ou dificultar as visitas de forma autoritária, entre outras atitudes por parte do alienador, fere o direito dos filhos previsto na legislação. Para a autora, por ser uma forma de abuso do Poder Familiar, deve ser regulada por reprimenda estatal: "Observe-se 
que a previsão de norma sem sanção inviabiliza a efetividade do direito previsto" (p.16). Em referência ao Código Civil, existe a possibilidade da perda do poder familiar:

Art. 1.638. Perderá por ato judicial o poder familiar o pai ou a mãe que: .... IV - incidir, reiteradamente, nas faltas previstas no artigo antecedente. (grifo nosso)

Art. 1.637. Se o pai, ou a mãe, abusar de sua autoridade, faltando aos deveres a eles inerentes ou arruinando os bens dos filhos, cabe ao juiz, requerendo algum parente, ou o Ministério Público, adotar a medida que lhe pareça reclamada pela segurança do menor e seus haveres, até suspendendo o poder familiar, quando convenha. (grifo nosso)

Já era também prevista a imposição de multa pelo descumprimento dos deveres próprios ao poder familiar pela Lei 8069/90 que dispõe sobre o Estatuto da Criança e do Adolescente:

Art. 249. Descumprir, dolosa ou culposamente, os deveres inerentes ao pátrio poder familiar ou decorrente de tutela ou guarda, bem assim determinação da autoridade judiciária ou Conselho Tutelar: Pena - multa de três a vinte salários de referência, aplicando-se o dobro em caso de reincidência. (grifo nosso)

Outras medidas possibilitadas pela Lei $8069 / 90$ do ECA com teor semelhante ao da Lei 12.318/10:

Art. 129. São medidas aplicáveis aos pais ou responsável: III encaminhamento a tratamento psicológico ou psiquiátrico; VII advertência; VIII - perda da guarda; IX - destituição da tutela; X suspensão ou destituição do poder familiar. (grifo nosso)

Sobre o artigo 10 da Lei de AP, que objetivava criminalizar as falsas denúncias, justificou-se o veto pelo fato de que a sanção de natureza penal pode ser contra os interesses da criança e ainda de que o ECA conta com inúmeros instrumentos suficientes para inibir a prática da AP. Assinalam Figueredo e Alexandridis (2011):

Muito mais do que o teor punitivo das sanções impostas pela prática do crime relativo à alienação parental, o objetivo da sua tipificação é visto muito mais como um meio coercitivo para afastar a prática da conduta, aliás, segundo a 
gravidade da conduta praticada, o maior ou menor grau da alienação parental promovida, a tipificação também se mostra instrumento adequado na salvaguarda dos interesses do menor. (p.84)

O intuito primeiro das sanções previstas na Lei de alienação parental é menos a punição do alienador do que a medida protetiva para salvaguardar os interesses do menor. Observa-se esta finalidade na introdução dos instrumentos coercitivos no artigo 60, "da ampla utilização de instrumentos processuais aptos a inibir ou atenuar seus efeitos, segundo a gravidade do caso". (grifo nosso)

O Código Penal (Decreto-Lei n. 2.848) como alternativa ao veto do artigo 10 da Lei em questão configura crime de desobediência para o caso de descumprimento de ordem judicial, tão típico em casos de alienação parental: "Art. 330 - Desobedecer à ordem legal de funcionário público: Pena - detenção, de quinze dias a seis meses, e multa. (grifo nosso)".

Tanto antes como depois da Lei, encontram-se determinações de cumprimento de visitas sob pena de crime de desobediência e condenação. Citamos duas decisões semelhantes nesse sentido no Diário Oficial Estado de São Paulo. Em 20/06/2011 na página 2065:

Processo 0012849-15.2011.8.26.0003 - Procedimento Ordinário - Família - W. R. - S. B. - Vistos. I - Para meu controle e orientação ao cartório, anoto que as despesas processuais foram recolhidas a fls. 71/76, inclusive as despesas da diligência do oficial de justiça. II - Defiro o aditamento de fls. 82/87, que está em consonância com a decisão de fls. 80. Anote-se. III - Como constou da decisão de fls. 80, o exequente requereu outras medidas de caráter executório, nos autos da ação de regulamentação de visitas durante a qual as partes transigiram (feito 0003740-74.2011, em apenso). Todas essas medidas foram frustradas, em face da resistência da filha em deixar, na companhia do pai, o condomínio em que reside com a mãe. Há indícios de que a resistência da filha talvez decorra de alienação parental praticada pela mãe, ou no mínimo da mais absoluta omissão desta última, em estimular a filha a acompanhar o pai (o que da mesma forma poderá caracterizar alienação parental por omissão dolosa). De qualquer forma, meros indícios não foram considerados suficientes, para que fosse desde logo descartada, em definitivo, a possibilidade de a resistência da menor decorrer de insegurança dela própria. Justamente em face dessas dúvidas, nas diversas decisões proferidas no feito 0003740-74.2011, em apenso, houve sempre determinação para que a vontade da menor não fosse desrespeitada. Tal restrição teve por objetivo: a) em primeiro lugar, impedir que a menor pudesse sofrer traumas psicológicos, caso fosse obrigada a acompanhar o pai; b) em segundo lugar, viabilizar que os genitores e a menor se adaptassem à 
nova rotina; c) em terceiro lugar, permitir que houvesse tempo suficiente, para que a menor fosse convencida pela mãe, a acompanhar o pai; d) em quarto e último lugar, dar tempo aos genitores (em especial à mãe), para proporem ação revisional do regime de visitas, na hipótese do regime atual se mostrar inconveniente ou incompatível com a vontade e as possibilidades da filha menor. Esgotadas que foram todas as tentativas anteriores, urge que doravante nova orientação seja adotada, pois: a) houve tempo suficiente para que os genitores e a menor se adaptassem ao regime de visitas em vigor; b) a mãe teve tempo suficiente para convencer a filha a acompanhar o pai ou, na presença de eventual motivo relevante, para ajuizar ação com o objetivo de rever o atual regime de visitas; c) não há notícias de que o regime de visitas em vigor tenha sido atacado por ação revisional, menos ainda que a mãe tenha obtido antecipação da tutela, para que a filha não seja retirada pelo pai. Em face de tais circunstâncias, à mãe cabe cumprir estritamente o regime de visitas em vigor e convencer a filha a acompanhar o pai. Isto posto, defiro o pedido para que executada seja intimada a dar efetivo e imediato cumprimento ao regime de visitas em vigor, de forma a convencer a filha a acompanhar o exequente nos termos regulamentados, sob pena de incidir: a) em crime de desobediência, para cuja apuração será oportunamente adotado o procedimento previsto no art. 40 do CPP; b) na multa de $\mathbf{R} \$ 545,00$, devida de forma cumulativa a cada descumprimento (a cada tentativa frustrada de realização das visitas fora da residência materna), nos termos do art. 461, $\S 5^{\circ}$ do CPC. Esta decisão servirá de mandado, com o permissivo contido no artigo $172, \S 2{ }^{\circ}$ do CPC. Encaminhe-se o mandado ao setor de mandados, com urgência. Int. - ADV: ROSELI DOS SANTOS FERRAZ VERAS (OAB 77563/SP)

Escreveu-se na segunda decisão, em 29/12/2009, na página 413:

Processo 100.09.345500-2 - Outros Feitos não Especificados - Vistos. Concedo liminarmente a tutela jurisdicional, nos termos do artigo 461 , $\S 30$, do $\mathrm{CPC}$, determinando à ré que cumpra criteriosamente o regime de visitas homologado por sentença, tal qual exposto nos documentos de fls. 97/98, retomando o requerente as visitas desde logo, de conformidade com o estipulado para as festividades de final de ano e férias de janeiro (alíneas " $c$ " e " $d$ " do tópico 4 do acordo), sob pena de multa que fixo em $\mathbf{R} \$ \mathbf{2 . 0 0 0 , 0 0}$ (dois mil reais) para cada descumprimento. No caso de desobediência, além da multa, poderá ser expedido mandado de busca e apreensão para efetivação das visitas, sem prejuízo de remessa de peças ao juízo criminal para as providências cabíveis (art. 461, $\S \S 4^{\circ}$ e $5^{\circ}, \mathbf{C P C}$ ). Expeça-se o mandado de citação e intimação pessoal da ré, devendo a diligência ser realizada pelo oficial de justiça, com urgência. Ciência ao MP. - ADV. SANDRA REGINA VILELA (OAB $155350 / \mathrm{SP})$.

Além deste, a alienação parental pode ensejar o crime de denunciação caluniosa. A magistrada Maria Luiza Póvoa Cruz (2010) sugere que os promotores e magistrados civis, diante das falsas 
alegações, não atuem em dissociação de uma verdade real, devendo dar causa às acusações, e não recuar quando se provam ser inverídicas, e acrescenta:

Doutra feita, também não podemos esquecer que 'dar causa à investigação policial, de processo judicial, contra alguém, imputando-lhe crime de que o sabe inocente' é denunciação caluniosa, conforme preceitua o artigo 339 do Código Penal, sendo crime de ação pública incondicionada.

No III Congresso Paulista do IBDFAM, o Des. Caetano Lagrasta Neto aproximou a alienação parental do crime de tortura de forma que, segundo os princípios constitucionais ou do Direito Penal, existe previsão de punição àquele que, sob qualquer pretexto ou utilizando-se de quaisquer meios, promova tortura e suas respectivas sequelas:

Para atingir seu objetivo este não se peja de submeter - desde a criança e o adolescente - a um estado de tortura, visando sua colaboração no objetivo de alienar...

É evidente que a tortura mental, através da lavagem cerebral ou indução de comportamento contrário ao desenvolvimento e crescimento sadios, deve ser punida. Assim, temos casos de remoção compulsória de criança, por um dos genitores, residente no estrangeiro ou outro Estado, impedir ou dificultar visitas; subtrair o pagamento de pensão impossibilitando os estudos ou a sobrevivência da criança ou do adolescente, questões que de uma forma direta ou indireta atingem parentes ou responsáveis. (2009)

Sobre a definição de crime de tortura, Lei 9.455/97, "Art. 10: Constitui crime de tortura: "... II - submeter alguém, sob sua guarda, poder ou autoridade, com emprego de violência ou grave ameaça, a intenso sofrimento físico ou mental, como forma de aplicar castigo pessoal ou medida de caráter preventivo..." (grifo nosso). Quando a SAP vem acompanhada de alto grau de programação, pode constituir violência psicológica aproximando-se da definição de tortura na respectiva Lei.

A desembargadora aposentada Maria Berenice Dias evoca a responsabilidade dos operadores de justiça por uma atitude mais enérgica e menos silente em casos de AP: 
Flagrada a presença da Síndrome de Alienação Parental, é indispensável a responsabilização do genitor que age desta forma por ser sabedor da dificuldade de aferir a veracidade dos fatos e usa o filho com finalidade vingativa. Mister que sinta que há o risco, por exemplo, de perda de guarda, caso reste evidenciada a falsidade da denúncia levada a efeito. Sem haver punição a posturas que comprometem o sadio desenvolvimento do filho e colocam em risco seu equilíbrio emocional, certamente continuará aumentando esta onda de denúncias levadas de forma irresponsável. (2008, p.13)

O cumprimento de regulamentação de visitas pode ser executado na ação de obrigação de fazer. Segundo CPC (Lei 5.925) e ECA:

Art. 461 do CPC. Na ação que tenha por objeto o cumprimento de obrigação de fazer ou não fazer, o juiz concederá a tutela específica da obrigação ou, se procedente o pedido, determinará providências que assegurem o resultado prático equivalente ao do adimplemento. (Redação dada pela Lei no 8.952, de $13 / 12 / 1994) \ldots$ \&... 40 O juiz poderá, na hipótese do parágrafo anterior ou na sentença, impor multa diária ao réu, independentemente de pedido do autor, se for suficiente ou compatível com a obrigação, fixando-lhe prazo razoável para o cumprimento do preceito. (Incluído pela Lei no 8.952, de 13.12.1994)

Art. 213 do ECA: Na ação que tenha por objeto o cumprimento de obrigação de fazer ou não fazer, o juiz concederá a tutela específica da obrigação ou determinará providências que assegurem o resultado prático equivalente ao do adimplemento.

Para o advogado da área de família Rolf Madaleno (2002), a determinação de multa tem como objetivo, não o de recompensar o genitor, mas o de obrigar cumprimento das visitas:

O preceito cominatório não tem em mira compor o ressarcimento dos prejuízos, mas, sim, obter coercitivamente, o cumprimento da obrigação de fazer ou de não fazer fungível ou infungível. Busca atuar diretamente sobre a vontade da pessoa obrigada, estimulando a execução específica da sua obrigação, já que toda a condenação só pode produzir efeitos se acatada pelo devedor. Figura a pena pecuniária como um elemento de apoio ao convencimento do obrigado relutante, que passa a sofrer uma pressão psicológica pela imposição de multa medida pelo tempo de sua voluntária resistência em cumprir com a sua obrigação.

\section{Diante de inúmeros instrumentos na legislação para coibir a prática}

de alienação parental, alguns autores ressaltam a redundância da Lei pelo fato de sua proposição não ser novidade na doutrina e jurisprudência brasileira. Afirma Duarte (2010):

Nestes casos, já dispunha o magistrado, utilizando as ferramentas processuais inseridas no ordenamento jurídico, dos meios adequados para cessar o abuso do guardião no impedimento do exercício do direito de visita do outro; ou do não guardião que comete o abandono parental ou também abusa do exercício de seu direito, em não devolvendo o filho após consumado o período de visita. 
O Des. Antônio Carlos Mathias Coltro, em comunicação oral ${ }^{6}$, fez uma crítica à nova Lei, afirmando que o magistrado já dispunha de instrumentos para aplicar medidas previstas, ressaltando o caráter judicializante das questões de família.

Entretanto a Lei estabelece uma especificidade e organiza os instrumentos gerando maior conforto aos magistrados ao intervirem. $O$ poder de fazer cumprir as decisões apenas é assegurado por medidas coercitivas, muitas vezes evitadas pelo magistrado da área da família. Também se evita dar seguimento ao esclarecimento de falsas imputações e determinar punições, dissipando assim, o sentido maior de justiça. De acordo com Bedaque, citado por Cruz (2010):

O que não se pode mais aceitar é a suposta vinculação do juiz civil à denominada verdade formal, prevalecendo a verdade real apenas no âmbito penal. Tais expressões incluem-se entre aquelas que devem ser banidas da ciência processual. Verdade formal é sinônimo de mentira formal, pois constituem as duas faces do mesmo fenômeno: o julgamento feito à luz de elementos insuficientes para verificação da realidade jurídico-material. Aquele que não vê reconhecido o seu direito, em decorrência de um provimento injusto, passa a não crer mais na função jurisdicional. (p.17, 2009)

Podem-se apontar outros instrumentos jurídicos reguladores da AP. Considerando a teoria de Gardner, o convívio com o genitor alienado é o melhor antídoto contra a SAP. Dessa forma, a ampla convivência com o genitor que não detém guarda pode ser utilizado como instrumento regulador da AP. O Desembargador do E. Tribunal de Justiça de São Paulo, Dr. Caetano Lagrasta Neto, pioneiro na tese de que a guarda compartilhada pode ser utilizada como forma de inibir os efeitos da alienação parental, afirma:

Desta forma, a possibilidade de convívio com o filho para os pais separados deixará de ser arma de vingança, pois ambos terão igualdade de contato e vivência, com a aplicação da guarda compartilhada, fato que impedirá

\footnotetext{
${ }^{6}$ Palestra organizada pelo Prof. Dr. Francisco Jose Cahali com o Des. Antonio Carlos Mathias Coltro, o Juiz Elizio Luiz Perez, Dra. Sandra Regina Vilela, Dra. Fabiana Domingues Cardoso e Tamara Brockhausen no dia 22/11/2010 AASP-SP (Associação dos Advogados de São Paulo).
} 
que o acesso ao filho seja moeda de troca ou de desforra. (Lagrasta, 2009a), Agravo de Instrumento no 630.114-4/4 - 00 do TJSP, decisão dia 23/09/09).

Barreiro (2010) também reitera essa ideia: "A guarda compartilhada, quando aplicada em caso de litígio familiar entre casal que disputa a guarda de criança ou adolescente, pode ser uma solução viável para se evitar a alienação parental".

Para além das questões jurídicas que a Lei trata de regular, não se deve minimizar seu impacto cultural. Hironaka e Mônaco (2010) assinalam que o papel do magistrado ultrapassa o cuidado para com cada caso singular trazido ao judiciário e atinge a esfera social, atuando dessa forma na prevenção quanto a esse tipo de abuso:

Um poder judiciário atento e cuidadoso com questões assim delicadas e prejudiciais é, sem dúvida, um passo, um momento e um cenário muito propício para o resgate, o reparo e principalmente a coibição para que tais situações sejam rejeitadas, anuladas ou, no mínimo, minimizadas, alertando toda a sociedade para a conscientização da responsabilidade de pais e mães que estejam a causar tantos males para seus filhos. (grifo nosso)

Não se pode deixar de apontar os primeiros efeitos sociais e de prevenção da referida Lei. Mães que passam por separação têm procurado orientação jurídica, psicológica e na internet com certa preocupação de estarem cometendo alienação parental depois da separação. Também se mostram preocupadas com as punições. Outras vezes recebem e-mail de seu ex-marido advertindo-as contra alienação parental. Conhecendo a nova Lei, procuram profissionais para informar-se melhor sobre o assunto.

Pessoas que passam por SAP tiveram grande alívio ao identificar um nome para o problema, outras passaram a ver novas possibilidades de ação diante da situação complexa e outras tantas têm buscado ajuda mais cedo, antes de a situação ser grave ou irreversível. A nomeação de um problema facilita a divulgação sobre o tema, o acesso a informações, a busca de ajuda especializada e traz maior clareza sobre a hora de intervir legalmente se necessário.

A necessidade da Lei no Brasil, em parte, pode ser entendida em função da interpretação estreita dos Operadores do Direito quanto ao 
significado dos direitos de convivência familiar da criança. Além de a prática revelar uma determinação de visitas restrita, observa-se inação dos operadores diante das obstaculizações de contato, das falsas alegações e dos pedidos de mudança de cidade que são atendidos sem maiores exames quanto à possibilidade de AP. Raramente, quando a falsa alegação é comprovada, inverte-se a guarda. Os pedidos de suspensão de visitas são banalmente concedidos diante de qualquer acusação, muitas vezes sem determinar uma visita assistida, rompendo o vínculo afetivo bruscamente. Para Souza (2008), diversas novas leis, como esta em questão, vêm surgindo, no intuito de esclarecer a significação do instituto da guarda devido ao fato de o Código Civil ter tornado confusas as regras pertinentes à guarda ao não reservar tratamento isolado ao assunto. Refere a autora:

Infelizmente o que se vê na prática é que o cônjuge guardião é sempre quem, de fato, exerce sozinho o poder familiar, quando essa situação só deveria se verificar em casos patológicos de suspensão ou destituição da autoridade parental. Tal costume vicioso afronta a lei e prejudica os filhos de ampla convivência familiar (Art. 227 da Constituição Federal). (p. 9)

A prática judiciária, ao ser conivente com esse tipo de situação, calca uma cultura conivente com a alienação. Um pai que disputava pelo aumento de convívio com seus filhos, passou a ter as visitas interrompidas depois que o juiz afirmou em audiência: Criança vai apenas quando quiser, não pode obrigar. Na visita seguinte, a criança passou veementemente a recusar sair com o pai, então, o contato rompeu-se definitivamente. Sabe-se que frases como essas são usuais, no entanto o operador de direito não pode desconhecer o poder de suas palavras decorrente do lugar de autoridade e de saber frente às partes e os consequentes efeitos na subjetividade dos envolvidos. Cabe uma pergunta: para além da estrutura sintomática que se encontra na família que passa por SAP, quais os efeitos das intervenções do judiciário na produção dessa patologia? Segundo Brockhausen (2011b, no prelo): 
Como psicóloga jurídica, pude constatar que, diante da demora ou do silêncio do Judiciário, alguns pais desistiam do contato com seus filhos, outros passaram a cometer atos transgressores, ironicamente para manter seu direito de visitas ao filho. Ao negar a aplicação da lei para coibir os caprichos de um genitor, que usa o filho como instrumento de retaliação, o sistema judiciário é conivente com a transgressão participando do ciclo de violência. Foi possível observar o efeito perversor da falta da aplicação da sanção. Como transmitir ao filho a lei, elemento essencial ao amor parental, quando é negada aos genitores a aplicação da lei que prevê direitos de convivência entre pais e filhos? O amor necessita da lei e de seus limites. Dentre os novos sintomas da modernidade, a Alienação Parental parece coincidir com a patologia das relações familiares na vida moderna.

Um caso de ação de obrigação de fazer movida pelo pai em razão da obstaculização por parte da mãe de sua filha, exemplifica a enorme responsabilidade dos Operadores do Direito. A mãe trancava a criança de 10 anos sozinha em casa nas tardes para impedir que o pai a visitasse quando ela estivesse trabalhando, o que não foi levado pelos profissionais às últimas consequências. O pai, diante do recuo sucessivo do judiciário, procurou fazer justiça com as próprias mãos. Para garantir seu direito de visitas, passou a cometer atos transgressores como pular o muro do prédio, entrar junto com os carros pela porta da garagem e até mesmo levar choque elétrico para afastar quaisquer impedimentos à visita. A criança por sua vez encontrava-se em estado crônico de angústia, sendo diagnosticada com sintomas psíquicos agudos. Num contexto familiar como esse, geralmente nota-se a primeira defesa do operador de Direito Coitada dessa pobre criança, tem dois genitores seriamente perturbados , excluindo-se assim como parte integrante desse processo quando a demanda foi endereçada a ele, como profissional.

Quanto às determinações judiciais em relação a AP, encontram-se muitas decisões de primeira instância no sentido de advertir genitores a recuarem em alguma prática de alienação parental (ex: impedimento de visitas) sob pena de: configuração de alienação parental, instauração de procedimento para verificar alienação parental, inversão de guarda, perda ou suspensão do poder familiar, suspensão de visitas, inversão da obrigação de levar os filhos nas visitas e multa a cada visita frustrada. Também são usuais decisões judiciais de primeira instância que pedem urgência na realização de perícia psicológica por haver indícios de 
alienação parental e que negam pedido de suspensão de visita por haver indícios de alienação parental. Duas decisões judiciais apontam posturas mais firmes por parte dos magistrados. A primeira, publicada no Diário Oficial do Estado de São Paulo, dia 27/05/2011, página 1035:

-089.01.2010.004050-0/000000-000 - no ordem 652/2010 - Separação (Ordinário) - M. K. D. C. X J. C. P. D. C. - Fls. 171 - V. Em preparo de saneador, determino: 1) esclarecimento por parte do varão, a respeito de obstáculo às visitas determinadas pelo juízo (fls. 136/138), e a cuja observância já fora intimada pessoalmente; 2)indicação de parentes próximos das partes (ascendente e/ou colaterais, até o terceiro grau) residentes porventura na cidade, para o caso de eventual necessidade de alteração compulsória da guarda, se constatada a hipótese de alienação parental, evitando-se a institucionalização protetiva. Prazo: 10 (dez) dias. Decorridos, cls. Int. - ADV JOSÉ OTÁVIO DE ALMEIDA BARROS OAB/SP 170553 - ADV JUNOT DE LARA CARVALHO OAB/SP 72884. (grifo nOSSO)

Outra publicação de decisão no Diário da Justiça Eletrônico de São Paulo do dia 15/06/2011, p. 329, sobre diligência da Juíza do Foro Distrital de Embu-Guaçu, da comarca de Itapecirica em que pediu instauração de procedimento para verificar AP sem que fosse demandado pelas partes, provavelmente pelo fato de a magistrada entender que AP representa risco à formação da criança

177.01.2010.002654-5/000000-000 - no ordem 1484/2010 - (apensado ao processo 177.01.2008.000578-1/000000-000 - no ordem 439/2008) Regulamentação de Visitas - R. C. D. S. T. X E. L. D. S. - CONCLUSÃO Em , faço os presentes autos conclusos à MMa Juíza de Direito Titular do Foro Distrital de Embu-Guaçu, Comarca de Itapecerica da Serra/SP., Exma. Sra. Dra. PATRICIA PADILHA ASSUMPÇÃO.*.*.*.*.*.*.*.*.*.*.*.*.*.*.*.*.*. Maurício Antonio de Oliveira Diretor de Serviço Processo no 1484/10 Vistos. Diante do que consta dos autos e da concordância do Ministério Público, defiro o pedido de fls. 29, determinando-se a BUSCA E APREENSÃO da menor E.R.S e a sua entrega para a requerente, que permanecerá no final de semana em sua companhia, retirando a menor no sábado as 10:00 horas e devolvendo-a no domingo até as 19:00 horas. Sem prejuízo, determino de ofício instauração de procedimento de alienação parental, observando-se que o requerido poderá perder a guarda do menor e lhe [sic] aplicado [sic] multa. Desde logo, autorizo o concurso de força policial e arrombamento, quando tais medidas, a critério do Sr. Oficial de Justiça, se fizerem necessárias. Providenciem-se e expeçam-se o necessário. Cumpra-se, COM URGÊNCIA. Int. - ADV ANTONIO RIZZI OAB/SP 166129 - ADV RODRIGO JOSE TRINCAS FRAGOSO OAB/SP 235343

Por ser novo, o tema gera cautela quanto ao seu uso. Alguns juízes temem quanto aos efeitos das medidas mais radicais em famílias 
disfuncionais e quanto a possíveis desfechos inesperados. A Lei dá maior empoderamento ao juiz, que deve ter sensibilidade e conhecimento adequado sobre o tema para não proceder a intervenções inadequadas ou induzir a deslindes dramáticos. Alguns casos veiculados na mídia revelam esses riscos e não podem deixar de ser analisados e questionados. A importante progressão das advertências e sanções pode ajudar em uma atuação mais cuidadosa e dar um prognóstico do genitor alienador - se pretende ceder a alienação ou se ele vai continuar a burlar as ordens judiciais. O apoio e a maior proximidade do magistrado em relação à equipe técnica são fundamentais. Deve-se ater para que o uso do termo AP ou SAP não dispense análises mais profundas e encubra dificuldades importantes do genitor alienado. Simplificações do tipo "se um comete atos de alienação, o outro não comete", "se os dois cometem atos de alienação parental não tanto faz quem detém a guarda", "se um aliena, então outro automaticamente é melhor genitor", "se a mãe fala mal do pai então a acusação de abuso é falsa". Este tipo de pasteurização, entre outras tantas, pode levar a uma atuação precipitada, quando não prejudicial à família como um todo.

Entretanto, a necessidade da Lei surgiu com intuito de regular situações que passavam invisíveis aos olhos dos magistrados. Diante da lide parental, os operadores geralmente atuam a partir de generalizações, encobrindo os diferentes níveis de responsabilidades e dificuldades de cada genitor e criando racionalizações do tipo "os dois brigam". Assim recuam em casos de alienação parental.

Trata-se de dar o acento correto a certas questões no campo psicojurídico. Pequenas dificuldades na parentalidade do genitor alienado vêm sendo equiparadas à violência psicológica sistemática praticada pelo genitor alienador em relação à prole, como dois elementos que influenciam igualmente a hostilidade dos filhos frente ao genitor rejeitado. (Brockhausen, 2011b, no prelo).

A conclusão de um laudo profissional teve o efeito de autorização à mãe para aprofundar uma SAP em seus dois filhos. Constantemente a mãe agredia física e verbalmente o pai nos momentos de transição de visita. Gritava na frente dos filhos, cuspia-Ihe no rosto, chamava-o de 
ladrão e desferia tapas no genitor. Com a finalidade de anexar prova processual sobre o assédio materno, o pai passou a gravar as ligações telefônicas feitas por seus filhos instruídos pela voz da mãe: Eu sei que você está gravando, seu filho da puta, foda-se o juiz, pode gravar, vamos, diga, meu filho, que você vai matar seu pai se ele não desistir do processo, que você vai colocá-lo na cadeia, que você odeia ele e nunca mais quer vê-lo, que ele é um ladrão. O filho, em seguida, em tom robótico, ameaçava-o de morte, dizendo odiar ao pai e que nunca mais queria vê-lo. O juiz que aguardava a perícia para posicionar-se diante de caso tão grave, mais confuso ficou quando o profissional de Psicologia concluiu que tão grave quanto as acusações da mãe, eram as gravações telefônicas feitas pelo pai por serem invasivas, equivalendo dessa forma, o nível de violência praticado pelos dois genitores contra os filhos. O rumo da perícia e do processo levou ao empoderamento da mãe e ao rompimento completo dos laços entre pai e filhos.

A Lei vem apontar necessidade de maior estudo a respeito dos conflitos de alta litigância. Em famílias como estas, observa-se a enorme dificuldade de regulação por meio dos dispositivos da lei. Questões delicadas e complexas, como os níveis pronunciados de violência na célula familiar que passa por divórcio, colocam o profissional numa berlinda, pois, por exemplo, muitas vezes a SAP vem acompanhada de problemáticas maiores no campo da parentalidade, até mesmo por parte dos dois genitores. Por isso não somente os magistrados devem ter uma formação quanto a questões psicológicas, mas o trabalho da equipe de técnicos deve poder auxiliar de forma mais completa, apesar de sofrerem do excesso de trabalho e da falta de alta capacitação. Para a promotora de justiça Raquel Pacheco Ribeiro de Souza, as dificuldades enfrentadas pelos profissionais em casos complexos, não podem servir de desculpas quando crianças se encontram desamparadas em situações familiares tão graves: 
Não pode o direito desviar os olhos dessa realidade, ao fundamento de que a SAP é questão que deve ser tratada nos consultórios. Tampouco pode a psicanálise negar escuta a esses sujeitos padecentes, porque pacientes de difícil acesso. Nós, operadores do direito e profissionais da saúde mental, não podemos nos deixar ser engolidos por vazios retóricos e por comodismos covardes, enquanto há crianças em sofrimento, aguardando que alguém no mundo as proteja. Compreender o fenômeno SAP, saber como preveni-lo, como identificá-lo e como tratá-lo é mais do que um desafio. É uma missão indeclinável, que precisa ser enfrentada com urgência e com coragem, por todos aqueles que realmente se importam com a saúde psíquica das gerações futuras. (Souza,2009)

Para o magistrado, são questões delicadas que questionam os limites de sua atuação na medida em que uma criança pode rejeitar genitor por diversas causas e não apenas em função de uma SAP. Os abusos psicológicos, físicos, sexuais, a negligência ou o abandono praticado por um genitor são razões pelas quais uma criança pode rechaçá-lo, embora não seja em formato de campanha de desmoralização tão característico da SAP. Tanto genitores alienadores podem alegar denúncias para justificar a recusa da criança encobrindo sua programação, como um genitor incestuoso pode alegar que a criança o rejeita por ser vítima de SAP, encobrindo seu abuso.

Para além das condições de atuação dos profissionais, no Brasil, existem poucos dispositivos sociais e judiciais reguladores da AP ou do abuso do poder familiar. O direito comparado revela que a vida privada da família brasileira sofre pouca intervenção do Estado, deixando assim de regular mais eficazmente diversas situações abusivas. Talvez por este motivo, o Brasil seja o único país no mundo que criou uma lei específica para alienação parental.

Em diversos estados dos EUA, algumas leis internas podem ser apontadas como dispositivos reguladores quanto a SAP ou AP. Nos estados do Arizona e da Califórnia, a presunção pela guarda leva em consideração aquele genitor que garantir a maior convivência da criança com o outro genitor. Nesses estados, também se considera, ao atribuir a guarda, se um do genitores fez alguma falsa acusação ${ }^{7}$. No estado de New

\footnotetext{
${ }^{7}$ Informação disponível no site:

http://www.womenslaw.org/statutes_detail.php?statute_id=2637\#statute-top
} 
Jersey $^{8}$ o tribunal competente para questões de família será aquele do local em que a criança teve a sua residência nos últimos seis meses. A retirada da criança desse mesmo Estado (nativa no Estado ou residente há mais de cinco anos) é proibida sem a autorização dos dois genitores. Ainda é considerado na atribuição de guarda aquele genitor que tem maior capacidade de concordar, comunicar e cooperar em questões relativas à criança. Quando os pais não entram em acordo de custódia, o tribunal pode exigir que cada genitor apresente um plano de custódia. A ampla oferta de contato será levada em consideração pelo magistrado na atribuição de guarda. Tomar ou deter um filho menor, com o objetivo de escondê-lo do outro genitor, ou privá-lo de contato com a criança é crime. Ainda na lei de New Jersey, aplica-se um programa de educação obrigatório a pais divorciados no tribunal, duas vezes por mês, para ajudá-los a redimir os conflitos advindos da separação e seu impacto nos filhos.

Na Alemanha, o Tribunal de Cochen $^{9}$ tem um código de conduta no qual institui regras relacionadas aos advogados. Por exemplo, o advogado não deve perder de vista que os interesses da criança não correspondem necessariamente aos de seus pais, visando sempre, dessa forma, o bemestar da criança.

Esses tipos de dispositivos criam uma situação cultural diferenciada e autorreguladora para o abuso do poder familiar que, por não haver uma regulação judicial mais coerente no Brasil, atinge proporções enormes de violência psicológica infantil ligada às disputas do divórcio. Segundo Fonseca (2007, citado por Figueredo e Alexandridis, 2011), a legislação brasileira é branda quanto a este tipo de situação. Com relação à possibilidade da prisão, esclarece a autora: "Muito embora, no Direito brasileiro, a oposição de impedimento ao exercício do direito de visitas não seja considerada crime - ao contrário do que sucede em outros

\footnotetext{
${ }^{8}$ Informação disponível no site:

http://www.womenslaw.org/statutes_detail.php?statute_id=4091\#id-4118

${ }^{9}$ http://www.sos-papai.org/br_conduta_adv.html
} 
países", citando a legislação de países como a Noruega, França, Alemanha e a da Califórnia (EUA). (p. 85)

No Brasil, o Projeto Lei 6.937/06, arquivado em 2007, tipificava como crime a mudança domićlio do guardião com filho menor ou incapaz sem avisar o outro genitor ou Justiça. Uma atuação profissional mais atenciosa deve levar em consideração a possibilidade de AP quando existe esse tipo de pedido. Um estudo da jurisprudência dominante nos tribunais revela que o genitor que detém a guarda única da criança pode fixar sua residência; no entanto, nos casos de guarda compartilhada, está havendo uma tendência a mudar esse entendimento. Uma decisão do STJ em agravo de instrumento contraria o pedido da mãe em levar os filhos para os EUA, afastando-os do convívio com o pai, justificando ser a guarda compartilhada:

2008.002.05052 - AGRAVO DE INSTRUMENTO - DES. RICARDO RODRIGUES CARDOZO - Julgamento: 24/04/2008 - DECIMA QUINTA CAMARA CIVELGUARDA. VISITAÇÃO. MODIFICAÇÃO. MUDANÇA DE RESIDÊNCIA PARA OUTRO ESTADO. A Agravante pretende rever a decisão pela qual a juíza a quo, usando do seu poder de cautela, que, aliás, se acentua muito na área de família, mormente quando envolve interesse de menores, ao contrário, manteve as crianças com o pai e deferiu à mãe um regime de visitação semanal, nos finais da semana. Desta decisão é que veio este agravo. A agravante tem todo o direito de procurar novas oportunidades de emprego, mas ao fazê-lo deveria atentar para o fato de que tem dois filhos menores, está separada, ajustou a guarda compartilhada e que não tem um direito maior do que o do pai das crianças em tê-los consigo. Agravado e Agravante têm idênticos direitos e obrigações em relação aos filhos. A Lei não privilegia um em detrimento do outro. Por isso parte-se para o que é melhor para as crianças. Esta a visão moderna do direito de família quando se discute posse e guarda de filhos. No caso concreto, o pouco que se apresenta até o momento, deixa para esta Relatoria a certeza da sensatez da decisão agravada. Não há nenhum relato sério desabonador da conduta paterna. Ao contrário, há elementos que indicam ser ele um pai cuidadoso, sempre presente na vida dos filhos, ao contrário da mãe. São várias as declarações neste sentido, evidentemente, sem força para produzir um juízo certo de valor, mas como se está numa seara de mera fumaça de direito, vigora para o Agravado uma aparência de bom direito. 0 fato causador de toda problemática nasceu da própria decisão da Agravante de deixar o Rio. Ao fazê-lo, talvez não tenha pensado nos filhos, na mudança de meio, de escola, de amizades e o mais importante, no rareamento do convívio paterno. O laudo provisório da perita psicóloga sugere a manutenção do convívio dos filhos com a mãe, que por óbvio não está impedida de tê-los e de vê-los, mas indica o preparo dos menores para que sejam transferidos para São Paulo, se esta for a decisão judicial. Desta forma, se conclui que a transferência abrupta não seria uma medida salutar. As crianças estão bem com o genitor. É possível, mas não se sabe, se estariam bem com a mãe em São Paulo. Portanto, neste momento, considerando o 
princípio do melhor interesse das crianças e, certo de que o convívio materno não restará obstaculizado, é que se impõe a manutenção da decisão agravada. Recurso desprovido nos termos do voto do Desembargador Relator. (grifo nosso)

Outra decisão do STJ, nos autos da MC 16357/DF, negando suprimento de autorização paterna para fixar residência temporária no estrangeiro a pedido da mãe.

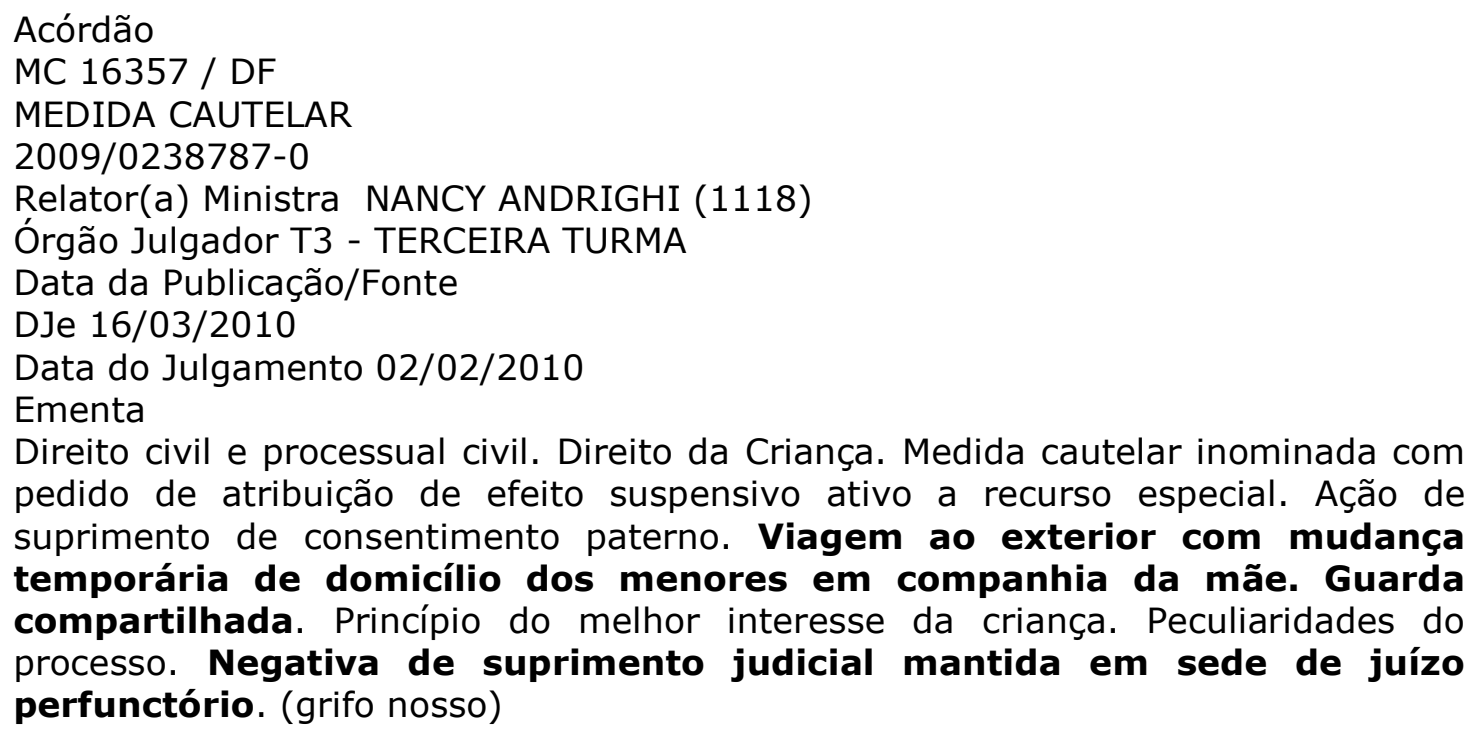

Tramita na Câmara dos Deputados projeto de lei sobre a mediação e outros meios de pacificação como etapa obrigatória em processos civis. Sabe-se que os meios alternativos de resolução de conflito consistem numa mudança de paradigmas na forma de entendê-los por não utilizar modelo linear inerente ao sistema judicial. A mediação abre as formas de entendimento do conflito ao focar na transformação das posições rígidas e regulação dos conflitos pelas próprias partes. A importância dessa ferramenta é aumentada quando se trata de relações continuadas como é o caso das Varas de Família. O sistema judicial pode aumentar a escalada cotidiana de violência e influenciar na instalação da SAP. A própria definição de Gardner, considera a SAP subproduto do sistema judicial. Ela surge nos conflitos de alta litigância sendo proporcional à intensidade deles. A mediação, em casos brandos ou medianos de SAP, pode ser vista como prevenção desses casos na medida em que a SAP (o uso das crianças como instrumento de batalha) é uma forma de empoderamento e 
barganha utilizada pelos genitores para obterem ganhos processuais e pessoais.

Existem outros tipos de dispositivos jurídicos reguladores da AP. A Lei 12.013/2009, que modificou a Lei de Diretrizes e Bases da Educação Nacional (Lei 9.394), passou a determinar, no artigo 12, a obrigatoriedade das escolas em prestar informações escolares aos pais conviventes ou não. É sabido que, além da dificuldade gerada pelo alienador impedindo que o alienado obtenha acesso a informações dos filhos, as escolas têm dificuldade em posicionar-se de forma coerente diante do conflito exacerbado entre os pais. Muitas vezes optam por uma postura mais confortável recusando-se a passar as informações aos genitores que não são guardiões. Um genitor pediu relatório de final de ano de seus dois filhos à escola, pois a mãe recusava-se a entregar-lhe depois de tê-lo recebido. Informado sobre a Lei 12.013, o pai enviou cópia desta à escola, que por sua vez respondeu que garantiria que a mãe enviasse o relatório em questão ao pai. Novamente a mãe negou-se a passar as informações e o pai exigiu que a escola providenciasse ao menos cópia do relatório. A escola, esquivando-se da sua incumbência, enviou documentos gerais sobre o ensino da escola e o desenvolvimento da turma, mas recusou-se novamente a enviar o relatório particular das crianças, contrariando o pedido do juiz. A justificativa: Não podemos produzir dois relatórios para todos os pais separados, a obrigação em passar o documento ao pai é da guardiã e não nossa. Diante desta resposta o juiz decidiu aplicar multa à instituição escolar. Algumas escolas, mesmo com a recente Lei, continuam a recusar-se em fornecer informações aos genitores visitadores. Tais atitudes têm gerado ações de indenização ou reclamação formal na delegacia de ensino. Espera-se que com a nova Lei e com as medidas coercitivas haja mudança na cultura quanto à conivência das escolas na perpetuação da AP. Também não deixa de ser importante o trabalho de orientação junto às instituições de ensino quanto a esse tipo de problemática. 
Outra recente Lei, 12.398/2011, dá direito aos avós de visitarem os netos. Sabe-se que não raro a alienação das crianças é estendida aos avós em casos de litígio, que passam do dia para a noite a serem excluídos da vida dos netos. Anteriormente à Lei, era ponto pacífico nos tribunais a concessão de visitas aos avós. O Dr. Euclides de Oliveira (2002), sobre o direito de visitas dos avós aos netos, demonstra que o contato com ambos os genitores não é o suficiente para a boa formação do menor:

Essa visão intimista do relacionamento familiar serve de pano de fundo à questão
do direito de visitas aos menores, que exige uma visão mais abrangente do que a
mera regulamentação legal restrita aos contatos dos menores com o pai ou a mãe
não encarregados da guarda, no caso de dissolução da sociedade conjugal ou de
outra forma de convivência. A consideração primeira é de que se busque a
preservação da comunidade familiar em que se integra o menor, como parte do
seu contexto de vida em sociedade. A esse respeito, determina a Constituição
Federal de 1988 , no artigo 227 , que constitui dever da família, da sociedade e do
Estado assegurar à criança e ao adolescente, dentre outros direitos básicos, o
direito à "convivência familiar e comunitária". Na mesma toada dispõe o Estatuto
da Criança e do Adolescente, Lei n. $8.069 / 90$, no artigo 16 , inciso V, com
repetição no capítulo III, sob a rubrica "Do direito à convivência familiar e
comunitária". Também serve de suporte o conceito de "família natural", inscrito
na Constituição, artigo 226 , $\S 40$, e no ECA, artigo 25 , em resguardo à
comunidade formada pelos pais ou qualquer deles e seus descendentes. (p.76) A recém-criada Vara Especializada em São Paulo (Foro Barra Funda) em violência doméstica conta com profissionais altamente especializados capazes de reconhecer as falsas alegações.

As novas resoluções da profissão do psicólogo, como a de 10/2010 do CFP que obriga o psicólogo a chamar a parte acusada para entrevista, poderão ajudar o profissional a posicionar-se mais criticamente diante de avaliações para detectar abuso sexual quando oriundas de uma SAP.

As denominações no direito como guarda, visitas, poder familiar, poder de fiscalização contribuem para uma compreensão social equivocada dos direitos e deveres dos pais após a separação. Podem, dessa forma, dar margem a interpretações abusivas e contribuir para estimular ou deixar de regular o abuso desse poder, induzindo ou intensificando os contextos familiares que envolvem situações de alienação. 
O direito de visita deve ser substituído pelo termo convivência paterno/materno-filial. A palavra visitas denota uma falta de intimidade, distância, formalismo, subentendendo uma importância secundária ao guardião e enfraquecendo os direitos e deveres de quem é o visitador.

A palavra guarda, por sua vez, resvala para noção de posse dos filhos, maior controle e poder sobre a prole, sensação de ganho no processo, deixando assim de regular melhor o abuso do poder familiar questão princeps em casos de alienação. Brito (2004), apresenta ideia nesse mesmo sentido:

A alegação de que no nosso país o poder familiar pertence tanto ao pai quanto à mãe, responsáveis por seus rebentos, termina por confirmar a hipótese de que não precisamos, portanto, dividi-los em duas categorias após a separação conjugal: a dos guardiães e a dos visitantes. A exemplo do que foi decidido em outros países, podemos abolir o termo guarda, mantendo apenas a expressão poder familiar. Caso a manutenção do termo guarda seja necessária, este deve estar acompanhado do adjetivo conjunta, facilitando a interpretação da equidade entre pai e mãe, assim como a indicação de um amplo contato da criança com ambos os genitores

Nas legislações estrangeiras, muitos termos como esses foram substituídos por não mais refletirem os valores modernos das relações familiares. $O$ pátrio poder também foi substituído por responsabilidade ou autoridade familiar, pois aquele termo espelhava o momento da sociedade patriarcal do século XX, que tinha o pai como pilar da estrutura familiar e que, por sua vez, mantinha uma relação de poder com os filhos, denotando um sentido de subjugação. No Brasil, quando se analisa a lei fria, o poder familiar dos genitores permanece inalterado após a separação, conforme determina o artigo 1632 e 1632 do Código Civil, isto é, os direitos e deveres de ambos os genitores se mantêm idênticos. Nessa lógica, formalmente a guarda compartilhada nada mais poderia acrescentar, a não ser o amplo convívio com o genitor com o qual a criança não reside ${ }^{10}$. Entretanto, não foi esta a opção do legislador ao definir a guarda compartilhada no parágrafo 1 do artigo 1.583 do Código Civil, como sendo "a responsabilização conjunta e o exercício de direitos e

\footnotetext{
${ }^{10}$ Agradecimento à advogada de família Dra. Sandra Vilela pela explicação.
} 
deveres do pai e da mãe que não vivam sob o mesmo teto, concernentes ao poder familiar dos filhos comuns". Na prática, quando a residência é fixada para um dos genitores, mesmo que haja ampla convivência, em casos de litígio, o poder familiar do outro genitor esvazia-se, restando-lhe apenas o direito de fiscalizar as decisões relativas aos filhos do outro genitor. O Jurista Dr. Eduardo de Oliveira Leite, em sua obra "Famílias Monoparentais" (1997), nesse mesmo sentido, interpreta a guarda como expressão mais veemente da autoridade parental:

A guarda é atribuída a um dos genitores, como prevê o texto legal, o exercício da autoridade parental persiste, mas os poderes que passarão a deter cada um dos genitores são desiguais, já que o detentor da guarda passa a exercer o essencial das prerrogativas decorrentes daquela autoridade, enquanto o outro genitor vê-se reduzido ao exercício de um direito de visita e de fiscalização. (p. 213)

$\mathrm{Na}$ guarda compartilhada, embora ela proponha uma divisão de tempo de convivência mais igualitária dos filhos com seus pais e evoque mais fortemente um sentido mais justo de direito e poderes dos genitores após a separação, ainda assim, poderão existir duas decisões unilaterais arbitrárias dos genitores em relação à prole. Embora não deixe de ser questão delicada e complexa, não se pode curvar e torcer os direitos dos filhos em função dos interesses egoísticos e pessoais dos genitores. Leite (1997, p. 284) defende a guarda conjunta para evitar que a criança crie uma imagem distorcida gerada pela exclusividade que guarda tradicional fomenta quando a criança vive só com um genitor. O genitor que não superou os conflitos da separação tende a afastar o outro do imaginário infantil, referindo-se a ele de forma depreciativa. O efeito é devastador, pois a criança precisa de ambos os pais. Para o autor, portanto, a guarda conjunta minora condutas desta natureza. Apesar das denominações jurídicas merecerem uma atenção especial, regulação do poder familiar revela ser questão demasiadamente complexa no pós-divórcio. Comel (2003), em sua obra "Do poder familiar", refere que o genitor que não detém a guarda permanece com a titularidade do poder familiar, mas seu exercício (poder de decisão sobre a vida dos filhos) é limitado. Segundo a autora, o pai pai-guardião concentra a função de tal maneira "...que é 
possível concluir que o que se the atribui é o exercício (do poder familiar), ainda que não de forma exclusiva, mas com relativa autonomia e independência diante do outro pai". (p. 246) Novo acento a estas questões complexas é trazido pelo entendimento da AP na Lei e suas consequências nefastas na vida dos filhos. Assim, vem a balizar a forma de pensar as denominações e a divisão dos poderes e guarda, trazendo um questionamento quanto à melhor regulação do poder familiar como forma de prevenção das situações de abuso psicológico infantil oriundas da AP.

Devido ao fato de a Lei 12.318 ser recente, pouco se tem acesso às decisões do Tribunal de São Paulo e de outros estados para saber o sentido da jurisprudência. Sobre as decisões de primeira instância, ainda podem ser reformadas pelo Tribunal. Pode-se analisar que a quantidade de utilização do termo AP nas decisões de primeira instância, posteriormente à Lei, aumentou significativamente indicando a sua boa receptividade pelos magistrados. No entanto uma decisão do STF de 1968 indicando fortes indícios de AP, demonstra que já havia instrumentos para coibir a prática:

RE 60265 / RJ - RIO DE JANEIRO

RECURSO EXTRAORDINÁRIO

Relator (a): Min. ELOY DA ROCHA

Julgamento: 12/05/1967 Órgão Julgador:

Publicação

RTJ VOL-04443-PP-***** DJ 20-12-1967 PP-04406

EMENTA VOL-00714-08 PP-02806 RTJ VOL-00044-01 PP-00043

Ementa

RECURSO EXTRAORDINÁRIO - DESQUITE E MANUTENÇÃO DE RELAÇÕES COM O FILHO DO CASAL - O JUIZ, AO DIRIMIR DIVERGENCIA ENTRE PAI E MÃE, NÃO SE DEVE RESTRINGIR A REGULAR AS VISITAS, ESTABELECENDO LIMITADOS HORARIOS EM DIA DETERMINADO DA SEMANA, O QUE REPRESENTA MEDIDA MINIMA. PREOCUPAÇÃO DO JUIZ, NESTA ORDENAÇÃO, SERÁ PROPICIAR A MANUTENÇÃO DAS RELAÇÕES DOS PAIS COM OS FILHOS. E PRECISO FIXAR REGRAS QUE NÃO PERMITAM QUE SE DESFACA A RELAÇÃO AFETVA ENTRE PAI E FILHO, ENTRE MÃE E FILHO. EM RELAÇÃO A GUARDA DOS FILHOS, EM QUALQUER MOMENTO, O JUIZ PODE SER CHAMADO A REVISAR A DECISÃO, ATENTO AO SISTEMA LEGAL. - O QUE PREPONDERA E O INTERESSE DOS FILHOS, E NÃO A PRETENSAO DO PAI OU DA MÃE. - RECURSO EXTRAORDINÁRIO PROVIDO. (grifo nosso) 
Já existem decisões de diversos Tribunais Estaduais determinando inversão de guarda em razão da AP. No Tribunal de Justiça do Rio de Janeiro:

0142612-80.2005.8.19.0001 - APELACAO - 1a Ementa - DES. MARCO AURELIO FROES - Julgamento: 27/10/2010 - NONA CAMARA CIVEL APELAÇÃO CÍVEL. Guarda de menor. Disputa entre os genitores. Sentença de procedência determinando a inversão da guarda, retirando-a da mãe e entregando ao pai, em razão do profundo processo de alienação parental praticado pela genitora, que já não administrava com zelo as atividades da criança. Acerto da sentença prolatada em sintonia com o posicionamento Ministerial colhido [sic] tanto em primeiro como em segundo graus de jurisdição. Art. 557, do CPC.NEGATIVA DE SEGUIMENTO DO RECURSO. (grifo nosso)

Uma decisão do TJSP recusa o pedido de suspensão de visitas em face do processo de Alienação Parental praticado pela apelante:

Tribunal de Justiça de São Paulo

Ementa

0005127-74.2004.8.26.0099 Apelação / Regulamentação de Visitas

Relator(a): Natan Zelinschi de Arruda

Comarca: Bragança Paulista

Órgão julgador: 4a Câmara de Direito Privado

Data do julgamento: $11 / 11 / 2010$

Data de registro: $29 / 11 / 2010$

Outros números: 990.10.217441-7

Ementa: Voto n. ${ }^{\circ} 14.804$ Regulamentação de visitas. Genitor apto ao exercício de direito. Criança com mais de oito anos. Pernoite está em condições de prevalecer. Oportunidade para que pai e filho, em ambiente descontraído, possam ampliar a afetividade. Prevalência do interesse do menor. Obstáculo apresentado pela genitora é prejudicial à criança. Individualismo da mãe deve ser afastado de plano. Procedimento da apelante caracteriza alienação parental. Recorrente já propusera ação de destituição de pátrio poder em face do recorrido, porém, sem sucesso. Beligerância entre as partes não pode afetar o relacionamento com o filho. Apelo desprovido. 


\section{FALSAS ALEGAÇõES DE ABUSO SEXUAL}

As falsas alegações de abuso sexual nos últimos anos vêm ganhando maior projeção quanto às discussões no meio profissional jurídico e psicológico. A recente Lei de alienação parental sobre a prática de falsas alegações, dentre elas a de abuso sexual, marca a evidência do tema. Dispõe o artigo 20:

Parágrafo único. São formas exemplificativas de alienação parental, além
dos atos assim declarados pelo juiz ou constatados por perícia, praticados
diretamente ou com auxílio de terceiros: VI - apresentar falsa denúncia contra
genitor, contra familiares deste ou contra avós, para obstar ou dificultar a
convivência deles com a criança ou adolescente...

Pode-se observar que a definição jurídica sobre falsas alegações pressupõe a prática de alienação parental, isto é, que a falsa denúncia tenha sido realizada a partir de um intuito alienador. Importante ressaltar esse aspecto em face de outras circunstâncias sob as quais uma falsa alegação de abuso sexual pode surgir, evitando assim deslindes judiciais equivocados ou estigmatização de pessoas. Por exemplo, na esfera legal principalmente, há que frisar a diferença entre uma falsa alegação fabricada, retaliativa, e uma falsa alegação que surgiu a partir de outros mecanismos, pois podem ensejar consequências opostas na saúde mental dos filhos. Neste exemplo, um genitor que acusa o outro para obter vantagens processuais ou por motivos retaliativos pode perder a guarda, situação muito diferente de um genitor que busca esclarecer uma suspeita e preocupa-se genuinamente com a proteção da criança. As falsas alegações podem surgir tanto a partir de mecanismos psíquicos que aparecem na mente da criança como na mente do adulto. Podem ser conscientes ou não, propositais ou não.

A partir de um estudo de revisão bibliográfica, Bernet (no prelo) classifica as diferentes formas de falsas alegações de abuso sexual. A SAP é apresentada como uma possibilidade dentre os dezesseis tipos de falsas alegações destacas pelo autor. Entre elas, encontram-se: sugestão, má interpretação de condições físicas, má interpretação de uma situação, 
delírio do genitor, delírio da criança, programação parental (SAP), sugestão do entrevistador, fantasia, má comunicação da criança, confabulação, pseudologia fantástica, mentira infantil inocente, mentira infantil deliberada, hiperestimulação, contágio grupal e substituição da figura do agressor. Essas definições comumente aparecem sobrepostas umas às outras, combinando duas ou mais delas, o que significa que, se uma delas foi detectada, não exclui necessariamente a possibilidade de uma falsa alegação ligar-se à SAP ou à programação do alienador.

Um caso de SAP com falsa alegação de abuso sexual foi gerada em meio à ação de obrigação de fazer na tentativa de o pai retomar as visitas obstaculizadas pela mãe. Mesmo depois da advertência do juiz, a mãe continuou a impedir as visitas. Como último artifício, tentou fazer uma falsa alegação de abuso. Informava que a filha de sete anos dissera: Não precisa mais levar o cachorro para dar banho no pet shop, eu já sei lavar o pipi dele! A mãe perguntou: Como assim? Ela respondeu: Meu pai me ensinou. A criança dissera que seu pai lhe dava banho e que ele deixou lavar seu pipi. Na avaliação psicológica, concluiu-se que não havia indícios de abuso. Neste caso, a mãe utilizou elementos da realidade para tentar forjar uma falsa alegação e afastar a criança do convívio com o pai. De fato pai e filha tomaram banhos juntos algumas vezes. A filha começou a desenvolver curiosidades acerca do pênis do pai, pedindo para passar a bucha com sabão no pai, este deixou por achar algo natural, o que foi explorado e aumentado pela mãe em algo abusivo.

Os contextos de alta litigância ou situações de disputa de guarda entre os cônjuges são apontados por muito especialistas (Bernet, 2006; Furniss, 1993; Darnall, 1998; Gardner,1998) como situações mais prováveis para a ocorrência das falsas alegações de abuso sexual infantil. No entanto podem também aparecer ligadas à SAP em outros contextos, isto é, não é necessário que haja uma disputa de guarda ou uma programação anterior a uma acusação para ela poder ser considerada falsa. Por exemplo, a falsa acusação pode disparar o início da SAP assim que a guarda é revertida. A atuação profissional reveste-se de especial 
atenção por poder produzir efeitos devastadores na subjetividade dos envolvidos.

O cenário de atraso das pesquisas no Brasil coloca os profissionais diante de desafios ainda maiores sobre tema tão complexo e espinhoso. A produção bibliográfica no país acerca do assunto revela-se demasiadamente escassa e isenta de discussões maiores como no campo da clínica, da prática investigativa, do diagnóstico diferencial, da técnica, entre outros. Alguns autores iniciaram a discussão do tema (Cavaggioni, Calçada e Neri, 2001; Shine, 2003; Calçada, 2005; Guazzelli, 2007; Bruno, 2007; Amendola, 2009; Lago e Bandeira, 2009). Nota-se que as primeiras produções datam aproximadamente do ano 2000, enquanto nos EUA o tema é assunto de pesquisas sistemáticas há décadas. Um estudo nacional que merece ser destacado, Amendola (2009), traz uma criteriosa discussão acerca das falsas alegações de abuso sexual ligadas a equívocos e distorções no campo do profissional da área da saúde.

Um dos tópicos mais complexos quanto à discussão das falsas alegações de abuso sexual deve-se ao relato da criança sobre referido abuso. O testemunho infantil vem sendo apontado nos estudos psicológicos como o mais confiável indício de situação abusiva, é uma modalidade conceitual e técnica avaliar a credibilidade do testemunho feito por crianças. No entanto, avaliadores, pela ânsia em proteger a criança, podem acabar por produzir estudos precipitados que atestam abuso a partir de relatos pobres e inconclusivos indicados como sinal inequívoco de abuso. Referem-se às falas da criança como relato detalhado ou relato vívido, quando, na realidade, não o são. A alegação da criança, segundo Furniss (1993), pode ser considerada uma suspeita de primeira linha, mas não necessariamente possibilita o diagnóstico diferencial que distingue alegações falsas e verdadeiras. Num caso relatado por Gardner (1998, p. 285), uma menina de 4 anos disse que não queria nunca mais ver seu pai, pois ele me penetrou. Quando perguntado à criança o que é penetrar? Esta respondeu Pergunte à minha mãe, ela que sabe o que significa. 
O questionamento sobre o histórico familiar antecedente à acusação, o surgimento da primeira desconfiança, a sequências das perguntas que foram feitas à criança, a reação e os pensamentos do adulto, os detalhes do suposto incidente em si e a cronologia dos fatos e a razão pela qual a criança poderia mentir são importantíssimos dados ao diagnóstico diferencial.

Uma suspeita de abuso sexual surgiu depois que conflitos familiares se acirraram na ocasião de separação do casal que morava com os pais da esposa. A criança se dirigiu ao avô materno quando este foi ao banheiro dizendo: Vovô deixa eu ver você fazer xixi? Na sequência, inúmeras perguntas foram feitas à criança de forma que ela acabou por dizer que viu o pai fazer xixi. Continuado o interrogatório persistente, ela acrescentou Meu pai me chamou quando ele fazia xixi e depois meu pai me chamou para ver ele fazer xixi. No mês subsequente, durante o banho, a avó continuou a fazer mais perguntas à neta e finalmente a criança disse que o papai colocava a mão na calcinha dela enquanto ela dormia na cama com a mãe. Foi verificado que a criança se masturbava frequentemente para escoar a ansiedade devido às fortes discussões entre os pais, e que a razão para a hipersexualização correlacionava-se às práticas da mãe no trato com a filha.

Conforme assinala Brockhausen (2011a, no prelo), não raro, psicólogos concluem a ocorrência de abuso a partir de qualquer relato infantil sem maiores considerações procedimentais. Por não haver durante a avaliação, inclusão de procedimentos para detectar falsa alegação, o estudo de início encontra-se viciado tendendo a detectar abuso quando não houve. Trabalhar com categorias e classificações descritivas pode elidir o aspecto clínico e singular de cada caso, encaixando os participantes nas descrições referidas pelos estudos sobre a família incestogênica. Trata-se de uma avaliação que pode assemelhar-se a uma cama de Proscruto ${ }^{11}$. Este revela ser um dos pontos em que o atraso das

\footnotetext{
11 "Procrusto era um bandido que vivia na serra de Elêusis. Em sua casa, ele tinha uma cama de ferro, que tinha seu exato tamanho, para a qual convidava todos os viajantes
} 
pesquisas na Psicologia brasileira afeta o trabalho do profissional de forma importante. As lacunas na produção nacional para detectar o falso abuso como ausência de protocolos de avaliação e de técnicas para detectar falso abuso, parâmetros para diagnóstico diferencial - são pontos cruciais a serem estudados para evitar que o trabalho do profissional reproduza uma violência psicológica.

Shine (2003) critica a utilização de perfil de abusador para confirmação da autoria do abuso. Para o autor, este modelo de atuação representa um obstáculo ético e epistemológico segundo os preceitos da psicanálise. Mesmo que o abuso na criança seja evidenciado, existe outra dificuldade: comprovar o nexo causal do referido abuso a um autor específico. Bernet (1993) levanta em seu artigo outra dificuldade, a possibilidade de a criança substituir a figura do agressor por outro inocente. Concluímos que as condições indicadas pelo perfil de abusador são frágeis para indicar uma ocorrência de abuso a suposto agressor. Por razões como essas, certos autores defendem uma abordagem terapêutica, a longo prazo, ao invés de uma abordagem pericial e rápida:

A proposta de Awad e McDonough, ligados ao Family Court Clinic de Toronto (Canadá), se baseia na experiência de que na maioria dos casos com crianças abaixo de seis anos, as avaliações breves geralmente falhavam em consubstanciar ou negar as alegações de abuso. Ao invés deste tipo de avaliação, eles propõem um modelo de tratamento a longo prazo, utilizando uma equipe de profissionais. (Shine, 2003, p. 240)

Ainda segundo Shine, parte do sucesso dos casos da Family Court Clinic deve-se à liberdade concedida pelo tribunal à equipe de saúde mental para decidir sobre a concessão das visitas a cada passo dos atendimentos.

para se deitarem. Se os hóspedes fossem demasiados altos, ele amputava o excesso de comprimento para ajustá-los à cama, os que tinham pequena estatura, eram esticados até atingirem o comprimento suficiente. Ninguém sobrevivia, pois nunca uma vítima se ajustava exatamente ao tamanho da cama. Procrusto representa a intolerância do homem em relação ao seu semelhante. O mito já foi usado como metáfora para criticar tentativas de imposição de um padrão em várias áreas do conhecimento, como na economia, na política, na educação, na história, na ciência e na administração." (Wikepidia) 
Inadvertidamente, o avaliador pode focar seu estudo na dupla abusado-abusador, em detrimento da avaliação de quem acusa. A dicotomia vítima $\mathrm{x}$ algoz, induzida a partir de uma grave acusação, constantemente arrasta os profissionais para uma atuação com base na identificação ao papel de salvador do fraco, do desprotegido, contaminando os procedimentos adotados na avaliação. Dessa forma, não deve ser descartado o exame rigoroso da pessoa que acusa para averiguar o conteúdo latente da acusação. Outro ponto, não menos importante, é que, ao ser considerada a possibilidade de inversão de guarda para pessoas que fazem acusações de abuso sexual, estas também devem ser rigorosamente avaliadas quanto à capacidade de zelar pela proteção da criança, seja física ou psicológica.

Quando a guarda é invertida em favor de um alienador, existe a possibilidade de inviabilizar o esclarecimento da demanda pelos profissionais ou ainda de provocar resultados enganosos na futura avaliação. Isso porque a complexidade de procedimentos necessários a uma avaliação de suspeita de abuso sexual junto ao contexto da SAP muitas vezes está fora do conhecimento, da capacidade, do tempo e do treinamento do profissional. Ou ainda, devido às dificuldades em avaliarse a SAP, pois a programação geralmente se intensifica, podendo ser sutil a ponto de os profissionais estarem impossibilitados de realizar um diagnóstico diferencial.

A respeito das rupturas de contato com genitor acusado, um terceiro neutro e próximo à criança pode ser a pessoa mais adequada para obter a guarda quando existe suspeita de uma programação por parte de quem faz a acusação de abuso sexual. Algumas decisões nos tribunais determinam que a guarda seja dada a esse terceiro. Esta possibilidade está prevista pelo Código Civil no art. 1.584: § 50:

Se o juiz verificar que o filho não deve permanecer sob a guarda do pai ou da mãe, deferirá a guarda à pessoa que revele compatibilidade com a natureza da medida, considerados, de preferência, o grau de parentesco e as relações de afinidade e afetividade. 
Encontrou-se uma decisão nesse sentido no Tribunal de Justiça do Rio grande do Sul, em 07/06/06. Segundo a Des. Maria Berenice Dias:

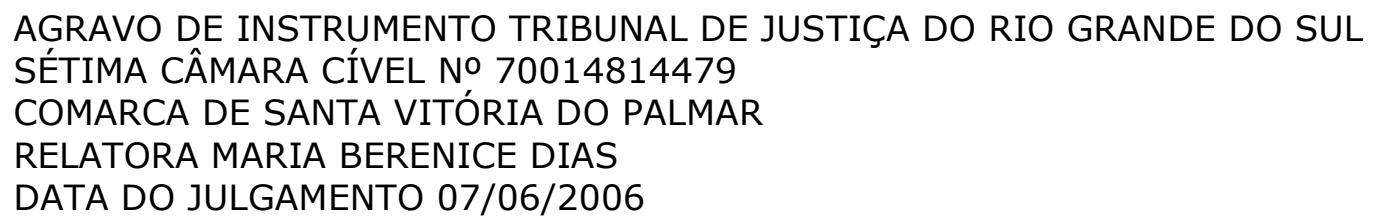

GUARDA. SUPERIOR INTERESSE DA CRIANÇA. SÍNDROME DA ALIENAÇÃO PARENTAL. Havendo na postura da genitora indícios da presença da síndrome da alienação parental, o que pode comprometer a integridade psicológica da filha, atende melhor ao interesse da infante, mantê-la sob a guarda provisória da avó paterna.

Negado provimento ao agravo. (grifo nosso)

Se por um lado, os Operadores do Direito preocupam-se em afastar a criança de suposto molestador, por que não considerar a proteção da mesma em relação a suspeita de violência psicológica quando a criança é mantida sob a égide exclusiva de um programador? A violência psicológica tem sido preterida quando comparada a outros tipos de violência, a Lei brasileira frisa a necessidade de atitudes mais coerentes por parte de promotores e magistrados. De acordo com a citação de Brito no prefácio (Amendola, 2009):

Não é difícil se encontrar afirmações sobre a invisibilidade dessa forma de violência, havendo muitas queixas de que as taxas de incidência seriam mínimas em relação aos casos reais. (p. 12).:

Ainda existe a possibilidade da falsa alegação de abuso infantil ser realizada por outras pessoas que não os genitores. Elas podem ser disparadas por pessoas que têm forte ligação emocional com a criança, mas não têm seu vínculo preservado judicialmente, como é o caso de familiares como padrastos, madrastas, tias e avós.

Registre-se outro caso semelhante em que a acusação de abuso é feita por outro familiar que não um dos pais. O pai acusado de abuso era separado de sua ex-esposa com a qual convivia bem. A mãe, pouco presente na vida da filha, deixou a criança morando com o pai, mas constantemente deixava a criança sob os cuidados de sua irmã, tia da criança. A tia, por sua vez, rivalizava os cuidados da criança com o pai. Os 
frequentes desentendimentos e intrigas familiares levaram a tia, que tinha um grande desejo de ter uma filha, a fazer uma alegação de abuso sexual contra seu ex-cunhado. Após a inversão de guarda em favor da tia em razão da acusação de abuso, as frequentes verificações desta no corpo da criança junto à difamação do pai fizeram a criança confirmar um abuso que nunca ocorrera. Os contatos entre criança, pai e mãe foram bruscamente rompidos. Com essa medida, os conflitos familiares reacenderam-se e a programação na criança intensificou-se. Com esse entorno familiar, a criança desenvolveu depressão e crises de pânico. Além desse fator, a frequente dicotomia gerada nos profissionais em tais casos, o lado bom e o lado mau, junto à pressa em tomar providências, resultou na falta de colher dados sobre a tia ao indicar-Ihe a guarda. Uma averiguação mais detalhada demonstrou que contra ela foram apresentadas, no Conselho Tutelar, diversas denúncias de negligência no trato com seu filho. Após a inversão de guarda, a tia passou a deixar a criança aos cuidados de parente com histórico de molestar diversas crianças da família, mesmo sabendo do fato.

$\mathrm{Na}$ prática judicial, as medidas apoiam-se frequentemente em relatórios de profissionais da área da saúde. Nesse sentido, o trabalho do psicólogo reveste-se de atenção especial. Não raro, documentos escritos por tais profissionais revelam uma produção unilateral, o que deve ser observado pelo julgador atentamente. As entrevistas são realizadas somente com a criança e com a parte que acusa, sem a participação ou convite do acusado ainda que ele possa recusar. Tampouco psicólogos têm indicado no estudo a razão da não inclusão de pessoa suspeita e o impacto de sua ausência na avaliação. Por vezes, chegam a fazer inferências sobre o suspeito ou sobre a relação deste com a criança sem ter realizado entrevistas com o mesmo ou sessões conjuntas para avaliar a relação do par. Nesse sentido, o CFP (Conselho Federal de Psicologia) elaborou a Resolução 10/2010 para regular de forma mais eficiente a atuação profissional diante de casos que envolvem suspeita de violência infantil, que determina: 
2. O Psicólogo, ao realizar o Estudo psicológico decorrente da escuta de crianças e adolescentes, deverá necessariamente incluir todas as pessoas envolvidas .... $2.1 \mathrm{Na}$ impossibilidade de escuta de um das partes envolvidas, o psicólogo incluirá em seu parecer o motivo do impedimento e suas implicações.

Alguns magistrados advertidos quanto a esta prática têm decidido relativizar o impacto de estudos unilaterais. Nos autos da apelação 280.982-4/9 da Comarca de São Paulo, em acórdão proferido pelo E. Tribunal de Justiça de São Paulo, o Desembargador Antônio Vilenilson assim se manifesta acerca de documento escrito por psicóloga, acusando um genitor de abuso sexual: "Fundar tão grave acusação no abalo emocional da criança (que outras causas poderia ter) e nas escoteiras declarações da mãe é agir com imprudência; é ser imperito do ponto de vista da especialidade; é agir de modo leviano".

O CRP (Conselho Regional de Psicologia) por sua vez regula e toma medidas punitivas a este tipo de atuação profissional:

Processo Ético-profissional

CFP no 4346/04 - Origem: CRP-06

Advertência. Confidencial: art. 62, § $1^{0}$ da Resolução de CFP no 006/01.

Ementa - Recurso contra decisão do Conselho Regional, que determinou a aplicação da pena de Advertência. Manutenção da decisão do Conselho Regional. Violação do art. 20, alínea "m" do Código de Ética Profissional do Psicólogo.

I - Pronunciamento do psicólogo em laudo psicológico de criança, emitindo opinião sobre o genitor sem a completa e devida avaliação psicológica do mesmo. Incorre em falta ética o psicólogo que adultera resultados, faz declarações e emite atestados sem a devida fundamentação técnico-científica.

II - Recurso conhecido e improvido.

Decisão (CRP): Advertência. Decisão (CFP): Advertência. Data do julgamento:05/11/04. Presidente Da sessão: Ricardo Figueiredo Moretzsohn. Relator: Aluízio Lopes de Brito. (grifo nosso)

E ainda:

Processo ético-profissional

CFP n 991/99 - origem CRP 12

Advertência - confidencial (art. 33 parágrafo único do código de processamento disciplinar)

Ementa - Processo Ético-Profissional. Recurso de Apelação.

Incidência dos Arts. 20, alínea "a", art. 20, alínea "m", e art. 47, do Código de ética dos Psicólogos.

I - Comete falta ética o psicólogo que produz diagnóstico ou faz afirmações sobre a personalidade de pessoas, em documento técnico, a partir apenas de informações de terceiros; que produz laudos ou pareceres sobre situação específica, a partir de dados parciais ou obtidos através de instrumentos não válidos. 
II - Apelação conhecida e improvida.

Decisão (CRP): Advertência - Decisão (CFP) Mantida - Data do julgamento: 19/11/99 - Presidente Ana Marcês Bahia Bock

Relator: José Carlos Tourinho e Silva (grifo nosso)

Genitores alienadores quando procuram o serviço de psicólogos, demandam que não questionem suas afirmações e que não avaliem a outra parte. O psicólogo pode constranger-se em chamar para avaliação o "molestador de crianças", postura que, de início, atesta o enviesamento que sofre o profissional. Dessa forma, a avaliação e a contraposição da outra parte deixa de ser realizada. Programadores buscam enfatizar suas alegações e com esse intuito buscam documento profissional unilateral mesmo quando providências legais já foram tomadas, o que por si descartaria a necessidade de documento de psicólogo para fins protetivos. A obstinação em produzir provas contra o outro genitor geralmente se associa à programação, ao passo que genitores que têm seus filhos abusados estão mais preocupados com a saúde da criança.

Ante a suspeita de abuso, os operadores bruscamente rompem o contato total entre a criança e o genitor acusado. No entanto, quando deferida a continuidade das visitas, pode-se amenizar possível SAP e evitar rupturas irreversíveis nos laços. Após a suspensão das visitas, alguns casos de síndrome de alienação parental aprofundam-se de tal maneira que a retomada dos vínculos se torna tarefa impossível. Manter as visitas pode evitar arraigar a ideia de abuso para o alienador e criança até que o estudo seja concluído. Dessa forma, entende-se que a decisão judicial de romper completamente as visitas pode participar do ciclo de alienação, calcando mais a violência psicológica e ajudando a intensificar a Síndrome. E, ainda conforme afirmado anteriormente por Gardner, o contato com o genitor revela ser o antídoto contra a SAP.

Fato é que, apesar dos estudos sobre abuso sexual infantil apontarem a probabilidade de ocorrência desse tipo de violência, não se pode inferir sobre a frequência das falsas alegações. $O$ assunto, por ser novo, necessita de pesquisas e especial atenção dos profissionais. Ademais, a proporção de casos de abuso e falsos abusos, quando diante 
de um estudo psicológico, pouco importa a um investigador criterioso e imparcial que deve considerar a mesma chance de ocorrência para as duas hipóteses desde o início da avaliação.

É necessário chamar à responsabilização os profissionais quanto aos danos subjetivos na família quando existe uma atuação inconsistente, despreparada ou equivocada. De acordo com Brockhausen (2011a, no prelo):

\begin{abstract}
Paralelamente à discussão sobre a violência praticada por um genitor que induz uma falsa alegação infantil, devemos questionar as consequências iatrogênicas da atuação profissional equivocada. A responsabilidade e ética profissional se fazem presentes à medida que se pressupõe uma relação de dissimetria, inerente à posição profissional (conhecimento do especialista e seu poder) em relação ao cliente. Por exemplo, muitos responsáveis por crianças desconhecem a sinuosidade da sexualidade infantil; no entanto é um conhecimento que não pode faltar ao psicólogo, bem como não pode deixar de ser considerado na hora de realizar uma avaliação ou orientar um familiar preocupado.
\end{abstract}

Houve um caso de pai separado que procurou advogada por estar preocupado com a possibilidade de sua filha ter sido abusada pelo avô materno. A profissional, em primeira instância, hesitou em entrar com pedido de inversão de guarda, encaminhando-o para uma rápida avaliação com psicóloga para evitar enganos e danos maiores a todos os envolvidos.

Segundo o pai, a criança dissera que o avô durante o banho mexera na sua periquita fazendo o som Ôooooo, o que deixou o pai assustado. $\mathrm{Na}$ avaliação verificou-se que anteriormente a esta suspeita, o casal parental tinha conflitos acentuados. Estes giravam em torno de uma preocupação do pai em relação aos cuidados da mãe para com a criança, a qual ele acreditava ser negligente.

Observou-se que suas queixas contra a mãe eram sempre em relação ao trato corporal da criança. Quando a menina de 4 anos foi avaliada em entrevista conjunta com o pai, notou-se que constantemente ele falava em tom autoritário com a filha, indicando que cada movimento dela oferecia perigos a seu corpo. Por exemplo, quando a criança brincando com a psicóloga colocou parte de sua perna fora do tapete no chão frio, o pai teve uma reação muito desproporcional gritando com a 
criança diversas vezes até ela recolher seu pé para dentro da área do tapete. Tirou a roupa da criança durante o atendimento para mostrar a falta de cuidado da mãe para com a filha, mostrando picadas de inseto que apareceram depois de uma viagem com a mãe. Mostrou ainda os dentes da criança, pois ela tinha uma cárie.

Dificuldades psíquicas do pai com tendências obsessivas e paranoides transformaram-se em constantes averiguações no corpo da criança e questionamentos excessivos. Sua mãe não cortou sua unha você vai se machucar, mande sua mãe lavar sua periquita direito, nunca deixe ninguém dar banho em você, apenas a vovó e a mamãe.

Verificou-se também que pai queria poder cuidar mais de sua filha, mas a distância o impedia de vê-la mais vezes. Queria saber mais de sua filha, mas o conflito com a ex-esposa fazia esta se afastar e não passar todas as informações detalhadamente como ele queria saber, o que por sua vez aumentava suas desconfianças. Acreditava que nenhum homem poderia dar banho em meninas, nem mesmo ele, o pai. Até que determinado dia, como de costume, perguntou quem dera banho na filha ouvindo uma resposta que causou indignação: $O$ vovô. A resposta disparou pensamentos perturbadores fazendo com que fizesse perguntas diretivas e repetidas para saber se estava sendo abusada, até o momento em que a criança trouxe o relato que confirmou a suspeita de abuso que ele perseguia. Como o vovô deu banho em você? Ele lavou sua periquita? Sua mãe está sabendo disso? Ele fez alguma coisa com você? Nunca mais deixe ele dar banho em você! Eu vou dar uma bronca na sua mãe! Depois de incessantes perguntas e marcações, a criança confirmou a pergunta do pai com um sim, então ele perguntou: Mas como ele fez? Ela respondeu: Ôoooooo.

Neste caso, as atitudes do pai não eram consistentes com a programação presente na SAP. A todo o momento, a dúvida preocupavao, reiterando que apenas queria ficar mais calmo, entender o que acontecera. Não queria provocar atrito familiar desnecessariamente, revelando cautela ao invés de uma obstinação em acusar e denegrir o avô 
e a mãe. Porém, caso não fosse a forma cuidadosa das profissionais no trato e no encaminhamento, poderia ter-se iniciado uma SAP pois o pai estava vulnerável, confuso e buscava orientação e apoio.

A cuidadosa atuação de uma profissional em caso de falsa alegação de abuso sexual indica que, se o profissional tem por obrigação ética não ser conivente com abuso sexual infantil, da mesma forma pode-se entender em relação a outros tipos de violência, dentre elas, a psicológica. Certa mãe que passava por um processo de separação procurou uma psicóloga, pedindo que elaborasse parecer confirmando abuso sexual de seu filho, praticado pelo pai, seu ex-cônjuge, sem incluí-lo nas entrevistas. Diante da constatação de que a alegação era falsa e cumpria objetivo de retaliar o ex-marido, a psicóloga optou por relatar o caso ao Conselho Tutelar.

Conforme mencionado anteriormente sobre os limites ao trabalho dos profissionais, pode-se apontar a estrutura e forma de funcionamento do judiciário como mais um desafio à prática. A falta de estrutura do judiciário junto ao formato do sistema, isto é, necessidade de uma solução objetiva e rápida, ignora que os casos de suspeita de abuso sexual exigem muito dos profissionais. Forçar uma resposta rápida enseja alto risco de efeitos deletérios às partes. O usuário do sistema por sua vez sofre os maiores prejuízos principalmente em casos com demandas mais complexas.

Em primeira instância, o afogamento do judiciário impõe demandas excessivas aos operadores impedindo uma atuação mais atenciosa. 0 tempo exíguo de dedicação a cada caso constantemente leva a uma simplificação na forma de atuar. A falta de acompanhamento, a médio e longo prazo, dos casos pelo profissional impede um feed back a respeito dos efeitos de sua atuação. Com essas restrições, medidas padronizadas ou genéricas geram conforto ao profissional. Elas podem cumprir com a economia de tempo no trabalho e encobrir o não-saber do profissional e possível angústia que pode ser despertada por casos deste tipo. No entanto tais padronizações são responsáveis por importantes enganos 
principalmente em casos de suspeita de abuso. Indícios de SAP podem equivocadamente ser apontados como diagnóstico diferencial para falsas alegações de abuso sexual. Para Gardner, indícios de uma SAP reduzem a probabilidade da ocorrência de um abuso real, no entanto a hipótese não deve ser descartada sem exames maiores. "Quando existe o abuso sexual, existe pouca ou nenhuma programação pelo genitor acusador". (Gardner, 1998 , p. 280) Outro ponto que pode gerar confusão deve-se à possibilidade de haver falsa alegação de abuso e não ser caso retaliativo ou de SAP.

Alguns cuidados procedimentais em avaliações desse tipo podem ser tomados pelos profissionais. O psicólogo que realizar avaliação para detectar abuso sexual, pode perguntar se as partes envolvidas na acusação passam por processo, qual o teor do processo e se o mesmo é anterior à suspeita de abuso. Também deve perguntar se houve quaisquer denúncias anteriores. Houve um caso de acusação de abuso sexual contra o pai de uma menina de 4 anos em que outra acusação de abuso da mãe da criança, desta vez contra a filha mais velha, revelou importantes informações a respeito do caso. A mãe, depois de uma briga com a filha mais velha, alegou que esta também abusara da pequena irmã. A mãe estava sofrendo de delírios paranoicos desencadeados depois de um evento de briga do casal em que o marido recusou-se a dar dinheiro para ela gastar em jogos de azar. Verificou-se que ela havia sofrido abusos na infância por parte do padrasto, o que pode ter gerado o conteúdo dos delírios persecutórios.

A consistência das afirmações de quem acusa devem ser questionadas. Por exemplo, a pessoa pode inventar sintomas na criança para confirmar sua tese sobre abuso. No entanto, quando o profissional conversa com os médicos da criança, professores e outros familiares, eles podem negar veementemente as informações do alienador. Uma mãe fora questionada em relação aos sintomas da filha supostamente oriundos do abuso do pai. Para sustentar sua acusação, dissera que o pediatra da criança a orientava para tratar os sintomas crônicos de encoprese, 
enurese e falta de apetite da criança. O mesmo, convocado em audiência, desmentiu qualquer afirmação por parte da mãe da criança, bem como a avó materna e a professora.

Quando se avaliam crianças abusadas, nota-se um histórico de abuso, diferentemente de casos de alienação parental em que o alienador geralmente aponta um evento único.

Outra dificuldade para o avaliador, geralmente para o perito, devese ao fato de que a criança e o acusador passam por um grande número de entrevistas (chegando a 12, 13) o que pode lapidar uma falsa alegação. O relato da criança de abuso incorpora-se cada vez mais e automatiza-se, perdendo os indícios da falsa alegação, como os olhares da criança ao genitor para buscar saber o que falar. Quando se examina o histórico dos falsos relatos em cada testemunho, verifica-se que são diferentes entre si, geralmente progressivos quanto à gravidade das informações ou contraditórios. No início da avaliação, é mais fácil averiguar o relato inconsistente e o relato bem fundamentado. Práticas libidinosas geralmente são mais difíceis de diagnosticar pelo fato de serem uma aproximação sedutora e não violenta.

A indução de falsa alegação pode ser feita por qualquer pessoa que tenha contato com a criança, desde pais, professores, familiares, entre outros. Houve caso de uma avó paterna que cuidou de sua neta por anos desde o nascimento enquanto a mãe da criança trabalhava. Quando o casal se separou, os conflitos familiares estenderam-se à avó paterna que foi afastada da criança pela mãe. A avó preocupava-se com os cuidados da mãe para com a filha e, quando tinha contato com a neta, checava todos os cuidados da mãe para com a criança. Certo dia a neta disse que brincava de pega-pega com seu padrasto, a avó perguntou: Mas ele te pega? A avó referiu que via tanta tragédia na TV que achava possível que algo assim acontecesse com a neta, pois a mãe não a olhava direito. Continuou checando: Quem te dá banho?, mas, segundo ela, a neta nuca confirmou algum abuso. O contexto situacional pode desencadear uma alegação de abuso sexual. Uma atuação preventiva da ocorrência de um 
abuso e da produção de uma falsa alegação foi foco de orientação terapêutica neste caso.

Deve-se considerar na avaliação que nem todo sintoma pode ser correlato ao suposto abuso sexual. Crianças que passam pelo divórcio dos pais associado a alta litigância, constantemente sofrem violência psicológica, frequentemente são intimidadas, ameaçadas, pressionadas ou colocadas diante de fortes conflitos de lealdade pelos pais. As contingências levam as crianças a responder à situação com a manifestação de fortes sintomas. Crises de agressividade e angústia, forte ansiedade, agitação psicomotora, pesadelos e até mesmo crianças mais sexualizadas podem utilizar a masturbação como via de escoamento da ansiedade. Para diferenciar sintomas gerados a partir da situação abusiva, o profissional deve ter conhecimento sobre a sexualidade infantil, desde as investigações, curiosidades, fantasias e teorias sexuais, o desejo incestuoso com o genitor do sexo oposto, a prática da masturbação. Evitam-se dessa forma confusões devido ao mito de que a criança não tem sexualidade. Outro mito deve-se à crença de que a criança não mente. O relato do abuso pode ser proposital, mas em crianças muito pequenas existe uma confusão entre fantasia e realidade devido à noção de verdade gradual. Elas também não sabem as consequências do que afirmam em relação à pessoa falsamente acusada.

Comumente verifica-se que acusações de abuso sexual surgem nos autos imediatamente após a troca de advogados do lado de quem acusa. $\mathrm{O}$ advogado anterior pode desencorajar o cliente a noticiar o abuso nos autos ao perceber o intuito do cliente em forjar uma falsa acusação, pode haver rejeição por parte do profissional, o que provoca desgaste da relação cliente-advogado. Este acaba por pedir para sair do processo ou pode ser trocado pelo cliente por um novo advogado que desta vez sustente uma hipótese de falsa alegação. O novo advogado, por sua vez, desconhece a postura e o histórico do cliente ao longo do processo.

Gardner propõe critérios para diagnóstico diferencial entre falsas alegações de abuso originadas a partir de uma SAP e as alegações de 
abuso verdadeiras. Ele aponta que alguns sintomas na criança servem de diagnóstico diferencial e outros não. Também faz uma análise comparativa entre genitores abusivos e alienados e genitores programadores e pais de crianças verdadeiramente abusadas.

As queixas de crianças abusadas sobre o genitor abusivo não apresentam a qualidade de difamação como na SAP, a não ser que exista litígio entre as partes. Neste caso, deve-se averiguar o momento em que as queixas da criança surgiram, se foram anteriores ao conflito parental ou se datam de um histórico passado de queixas relacionadas ao abuso. A criança alienada apresenta uma boa relação com o genitor anteriormente aos conflitos parentais; por sua vez, a criança abusada, não.

A criança verdadeiramente abusada não apresenta fenômenos de independência, isto é, não tem necessidade de proclamar que sua animosidade contra o genitor nada tem a ver com o alienador e que a escolha de não vê-lo é sua.

No caso de SAP severa, o diagnóstico diferencial pode trazer dificuldades, pois geralmente as crianças têm delírios paranoides e os sintomas são mais severos, podendo assemelhar-se a alguns sintomas de crianças abusadas.

Crianças alienadas não têm preocupação com evento traumático de abuso, enquanto as crianças abusadas podem desenvolver obsessões quando ao trauma. As crianças abusadas apresentam uma série de sintomas que as crianças alienadas não apresentam: hipervigilância, dissociação, despersonalização, entorpecimento psíquico, sentimento de desrealização, flash back do trauma, reação de sobressaltos, pessimismo futuro, não têm projetos de vida. Episódios de ausência são comuns em criança alienadas e devem ser diferenciados do sintoma de dissociação presente em crianças abusadas. Pesadelos em crianças abusadas devem ser averiguados quando ao conteúdo traumático para verificar a diferença de pesadelos usuais em crianças saudáveis. O medo da criança do genitor acusado não pode ser utilizado como critério diferencial para o 
diagnóstico, pois tanto crianças abusadas como alienadas podem desenvolver raiva ou medo do genitor.

Uma análise das decisões do Poder Judiciário revelam não ser novidade a constatação das falsas alegações de abuso sexual. Um dos maiores juristas brasileiros, Saulo Ramos (2007), no seu livro autobiográfico, conta o maior desafio de sua carreira como advogado provar uma falsa alegação de abuso sexual em meados da década de sessenta:

Imperdoável.... o fato de ensinar crianças a contarem coisas imorais, para produzir prova contra ex-marido. E por quê? O que levaria uma mulher, por mais depravada que fosse, a deixar de proteger a pureza de seus próprios filhos, ensinando-Ihes não a prática de atos horríveis narrados, mas como descrevê-los, o que, na sensibilidade delas, deveria causar o mesmo e irreparável estrago pelo resto da vida. (p. 63)

Já existem decisões do TJSP associando SAP e falsa acusação de abuso sexual:

Número do processo: $\quad 1.0024 .08 .984043-3 / 004(1)$

Única: 9840433-67.2008.8.13.0024

Tribunal de Justiça de Minas Gerais

Relator: Des.(a) EDILSON FERNANDES

Data do Julgamento: $14 / 09 / 2010$

Data da Publicação: 24/09/2010

Ementa:

REgULAMENTAÇÃO DE VISITAS - ACUSAÇÕES DE OCORRÊnCIA DE ABUSOS SEXUAIS DO PAI CONTRA OS FILHOS - AUSÊNCIA DE PROVA SÍNDROME DA ALIENAÇÃO PARENTAL CARACTERIZADA DESPROVIMENTO DO RECURSO. É indispensável a fixação de visitas ao ascendente afastado do constante convívio com os filhos, em virtude do fim do casamento dos pais, conforme prescreve os artigos 1589 e 1632 do Código Civil.

A prática de abusos sexuais deve ser cabalmente comprovada, sob pena de inadmissível afastamento do pai da criação da prole, medida esta que culmina em graves e até mesmo irreversíveis gravames psíquicos aos envolvidos. O conjunto probatório que não demonstra o abuso sexual sustentado pela genitora, com autoria atribuída ao pai dos infantes, aliada às demais provas que comprovam a insatisfação dos filhos com o término do relacionamento do casal, inviabiliza a restrição do direito de visitas atribuído ao ascendente afastado da prole, mormente diante da caracterização da síndrome da alienação parental.

Súmula: NEGARAM PROVIMENTO.

Acórdão: Inteiro Teor (grifo nosso)

Anteriormente à aprovação da Lei de AP, decisões do TJSP já apontavam pela necessidade de ser mantida a convivência da criança com 
o genitor que está sendo alvo da acusação, como se pode observar na decisão do TJSP em 03/10/2007:

Tribunal de Justiça de São Paulo

Voto n. 15.015 - 8a Câmara de Direito Privado

Agravo de Instrumento n. 489.317-4/9 - São Paulo

Medida cautelar. Suspensão de visita. Acórdão que restabeleceu o regime de visitas diante da ausência de prova concreta de maus-tratos e abuso sexual. Alegação de impossibilidade de aplicação imediata da decisão diante da interposição de Embargos de Declaração. Embargos rejeitados e considerados protelatórios. Perda do objeto. Recursos especial e extraordinário interpostos. Irrelevância. (grifo nosso)

A magistrada Maria Luiza Povoa Cruz (2010) frisa a necessidade de cuidados redobrados e agilidade quando o juiz se depara diante de graves acusações trazidas através de provas unilaterais e boletins de ocorrência no contexto de separação:

O Juízo da Vara de Família, recebendo tal documentação, que acompanha a inicial, prontamente, suspende as visitas do genitor ao menor. Está consolidado o que a alienadora (mãe) busca: o calvário do genitor que, sem qualquer prova contundente, é penalizado ao início da demanda.

Pois bem, a Carta Magna reza: "Ninguém será considerado culpado até o trânsito em julgado da sentença penal condenatória" (artigo 50, inciso LVII). Mas, no Juízo da Vara de Família, a ação inicia-se penalizando o genitor e também o menor.

....Penaliza-se, depois se produzem provas, no Juízo da Família. Audiências, inspeção judicial, laudos de peritos da área são realizados após genitor e criança/adolescente serem separados pelo Juízo da causa.

De acordo com a Des. Maria Berenice Dias (2008), os magistrados, em nome da proteção integral da criança, precipitadamente rompem um vínculo afetivo de convivência indispensável ao desenvolvimento saudável e integral de crianças em desenvolvimento. Ela afirma:

Flagrada a presença da Síndrome de Alienação Parental, é indispensável a responsabilização do genitor que age desta forma por ser sabedor da dificuldade de aferir a veracidade dos fatos e usa o filho com finalidade vingativa. Mister que sinta que há o risco, por exemplo, de perda de guarda, caso reste evidenciada a falsidade de denúncia levada a efeito. Sem haver punição a posturas que comprometem o sadio desenvolvimento do filho e colocam em risco seu equilíbrio emocional, certamente continuará aumentando esta onda de denúncias levadas a efeito de forma irresponsável. (p. 13) 


\section{SOBRE A ARTICULAÇÃO DA SAP À PSICANÁLISE}

\subsection{PANORAMA}

Gardner descreve uma síndrome cujo conjunto de sintomas na criança aparece ligado a uma causa - a programação sistemática do genitor alienador. Esse quadro clínico tem recebido criticas por profissionais da saúde mental em torno de duas questões principais: a atribuição patológica proposta pelo autor e a explicação causal linear/única. Justifica-se que esse enquadre opera uma redução da problemática.

A psicanálise pode trazer uma compreensão da síndrome além das descrições fenomenológicas, articulando-a a uma concepção que permita situar sua complexidade e dinâmica. Trata-se de distinguir uma invariante, uma estrutura constante e universal, isto é, suas determinações, das diferentes formas da apresentação clínica que podem acompanhar a SAP.

Busca-se neste trabalho ir além da variedade das formas que Gardner captou com sua observação clínica, entendendo que a redução a uma síndrome pode ser empobrecedora diante da questão. Dessa forma, pretende-se através da psicanálise restaurar a SAP a partir da determinação de seus termos genético-estruturais.

A SAP, por ser considerada uma patologia psiquiátrico-psicológica, pode ser incluída no modelo clássico de clínica inspirado na medicina. Esse modelo estabelece uma relação direta entre o signo e o referente e baseia-se em "classificações exaustivas e descrições objetivantes". (Dunker, 2001, p. 14) Neste trabalho será realizado a passagem para um "modelo que obedece ao princípio de coerência e covariância" (Dunker, 2001 , p. 14) entre os elementos que compõem a estrutura e que consideram os vários agentes incluídos na situação que enunciam. (Dunker, 2001, p. 14) Pretende-se contribuir para a formalização de um modelo que inclua as diferentes casuísticas, explicando a síndrome em termos genético-estruturais e não apenas descrevê-la. Busca-se desta 
forma uma precisão diagnóstica que possa trazer contribuições ao tratamento e sua regulação no interior do dispositivo jurídico.

Do ponto vista estrutural, a SAP apresenta-se como uma transferência entre a criança e o genitor alienador induzida com finalidade de exclusão do genitor alienado da transmissão simbólica da linhagem e dos ideais para a criança.

Do ponto de vista da gênese, a SAP apresenta-se como um reforçamento da alienação fundamental, própria da constituição do sujeito, instalada por uma demanda imperativa através de várias estratégias: retirada do amor, acesso ao gozo e oferta de saber.

A gênese da SAP, ao ser explicitada pela psicanálise, esclarece a eficácia do alienador em minimizar e até desfazer os laços afetivo-sociais. Para isso, tem-se que entender o lugar e função dos genitores na constituição do sujeito.

\subsection{A CONCEITOS PSICANALÍTICOS}

\subsubsection{A criança, o sujeito, a infância e infantil}

Para articular os dois campos, será formalizado o objeto de estudo nos dois modelos apresentados - a SAP de Gardner e a SAP segundo uma leitura psicanalítica. Para seu criador, a SAP é uma patologia psiquiátricopsicológica que pode acometer crianças, adolescentes e até mesmo adultos. O escopo do trabalho dar-se-á em torno da SAP na criança pelo fato de ela ser identificada na prática como o alvo mais suscetível a programação devido à dependência do cuidador. Seu enfoque também se dará devido à necessária proteção em relação às situações abusivas na criança. A abordagem pretendida leva em consideração a SAP na criança neurótica devido a uma formalização necessária a um trabalho preliminar diagnóstico, próprio do campo psicanalítico, que parte do conceito de estrutura. Busca-se extrair consequências particulares desse recorte, 
articulando o conceito de SAP na criança ao da SAP formulada pela psicanálise.

O termo criança na Psicologia ou em outras ciências está impregnado de noções de diferentes esferas - Direito, Psicologia, Medicina, Educação e Sociologia - e parte de uma ideia geral do ser criança como uma fase passageira da vida que termina no início da puberdade. Conceito que a psicanálise diferencia, introduzindo a noção de sujeito para definir operadores de sua práxis.

Gardner estabelece suas teorizações a partir do objeto empírico criança para fazer um diagnóstico de uma patologia. A definição de criança em diferentes disciplinas dá-se a partir do que é observável, objetivável e compreendido sobre o objeto empírico "criança". Vorcaro (1997) discute as implicações na forma de conhecimento da criança quando esta "é investigada enquanto objeto de estudo na Psicologia e na psiquiatria" (p. 22). A partir dessa criança "concreta" se estabelece o normal e o patológico "em consonância aos parâmetros validados na ciência". (p. 22)

A adoção de uma psicopatologia da criança, conforme faz Gardner, implica que o conjunto de sinais e sintomas define a diagnóstica e a terapêutica. Sendo assim, a produção de conhecimento a respeito da criança distingue-se pelo caráter ideal metodológico que se visa atingir. Segundo Vorcaro (1997), esse modo de produção de conhecimento visa responder ao que na criança resiste ao ideal. Ideal que ela encarna tanto socialmente, como em relação às expectativas parentais, aos médicos e psicólogos; quando uma morbidade qualquer a atinge, denuncia assim um mal-estar, um furo no projeto social, ao ideal médico e ao ideal familiar. Nesta visão, o sintoma que a criança apresenta tem de ser corrigido, pois algo não vai bem. Os Operadores do Direito costumam entender que a rejeição ao genitor representa uma resposta absoluta, verdadeira por si só, uma resposta genuína. Ao contrário do que se permite situar através da psicanálise, cada resposta deve ser escutada em sua particularidade, não permitindo generalizações. Uma resposta pode ser genuína, devendo 
portanto ser sustentada ou então sintomática representando mais uma alienação do desejo do sujeito.

A teoria de Gardner, baseada no singular do caso, denuncia a distorção presente num modelo que se baseia num ideal da criança e sua relação com a parentalidade: a criança é pura e espontânea, sua expressão afetivo-emocional é verdadeira e seu querer é genuíno. A rejeição ao pai é um enunciado que só adquire valor a partir da enunciação, é um querer que não tem valor absoluto, que precisa ser decifrado. Freud apontou que o verbal presente na fala nem sempre coincide com a posição desejante, necessitando de um desvelamento. Ao ratificar a rejeição na SAP a partir da fala da criança, o profissional autoriza a alienação, por sentir-se mal em opor-se à vontade de um um frágil e pequeno ser. Vontade que, para a psicanálise, não representa necessariamente a verdade do desejo do sujeito.

É nesse sentido que a ferramenta criada por Gardner ao diferenciar SAP e AP, pois esta última é justificada e genuína, contribui para o diagnóstico diferencial da recusa da criança ao genitor, balizando a intervenção do operador do Direito para a consecução de uma medida eficaz e protetiva da criança. Ou seja, a rejeição ao genitor é uma fala que remete a uma criança empírica que por si só não permite situar sua posição subjetiva. Às vezes a fala, o querer, coincide com o sujeito desejante, nesse sentido o apoio do genitor a posição da criança representa algo genuíno.

Freud partiu de um ideal de criança segundo parâmetros externos, mas foi se afastando gradualmente da noção de desenvolvimento baseada no fator biológico e substituindo-a pela noção de sujeito atrelada ao novo conceito de sexualidade. No texto "Organização Genital Infantil" (1923), ele afirma que o psíquico não é algo previamente dado, mas constituído através de um processo. Ele separa a ordem humana da ordem instintual e animal, pois considera como ponto de partida a prematuração do ser humano ao nascer. Se o sujeito só se desenvolve no meio familiar, isto quer dizer que ele não se institui naturalmente como puro produto da 
genética e da biologia, mas que depende de outro humano considerado em sua subjetividade.

Para a psicanálise, a criança não equivale à concepção de sujeito, assim como infância não é sinônimo de infantil. Tem-se que situar qual o conceito de sujeito e infantil com o qual a psicanálise opera, marcando as diferenças em relação à criança e à infância, o que permitirá extrair consequências da leitura psicanalítica da SAP.

Em 1905 nos "Três ensaios sobre a teoria da sexualidade", o neurótico é visto como o indivíduo cuja sexualidade conserva a essência infantil. Separa-se a ideia de infância como tempo cronológico do desenvolvimento biológico de um novo conceito - o infantil. A separação nítida e categórica entre o adulto e a criança vai sendo cada vez mais posta de lado por Freud. No texto "A negativa" (1925/1996), a posição infantil de negar a castração equipara-se à mesma posição do neurótico "adulto". Marca-se na teoria freudiana um abandono progressivo da visão da criança, como integrante de uma fase de desenvolvimento da vida, para adoção de uma concepção de sujeito, que Lacan levou até as últimas consequências e de onde extraiu grande parte de sua contribuição à psicanálise.

Sobre o sujeito lacaniano, Prates (2006) afirma que o tempo de resposta do sujeito na constituição subjetiva é lógico e, portanto, não pode ser sobreposto ao tempo do desenvolvimento da criança, que é uma fase da vida. Afirma a autora que a psicanálise não opera com uma distinção rígida entre adulto e criança como categorias preexistentes. No entanto não se trata de negarmos que a criança exista, a criança é uma pessoa. Mas não é dela que a psicanálise se ocupa como ciência, isto é, na clínica não há criança ou adulto, há um sujeito e é dele que se trata.

Por ser o objeto do estudo psicanalítico, o sujeito do inconsciente, a noção de "criança" não é elevada ao estatuto de conceito. Não é um terno a partir do qual se pode operar na clínica. Assim, para evitar imprecisões, não se deve sobrepor o conceito de criança e sujeito. Outra distinção 
essencial que permite situar o campo da psicanálise deve-se ao conceito de infância e infantil.

A crítica que a psicanálise faz ao diagnóstico baseado na criança e nos sintomas, conforme propõe Gardner, deve-se ao fato de tomar-se como ideal um desenvolvimento obtido por normas estatísticas que ignoram a singularidade do sujeito. No entanto, à primeira vista, pode-se pensar que o projeto de Gardner pode ser engendrado nesse ideal: estabelecimento de uma causa única, uma causa fora do sujeito a partir do observável da criança. Nesse sentido, dever-se-ia rejeitar a SAP como valor diagnóstico, pois ele a situa como síndrome e não como resposta do sujeito.

O conceito de sujeito pressupõe uma atemporalidade, uma noção distinta da pessoa que se situa em relação ao tempo cronológico, marcado pelo ritmo biológico, por fases de desenvolvimento. Freud descobriu nos processos inconscientes atemporais uma indestrutibilidade, a do desejo. Atrelado ao desejo, encontra-se um sujeito, que se situa entre um futuro anterior e um passado hipotético que nunca foi. Nas formações do inconsciente (sonho, sintoma, chiste, lapso e ato falho), ele descobriu inalterabilidade do recalcado como manifestação da estrutura do sujeito:

Os processos do sistema inconsciente são intemporais; isto é, não são ordenados temporalmente, não se alteram com a passagem do tempo; não têm absolutamente qualquer referência ao tempo. A referência ao tempo vincula-se, mais uma vez, ao trabalho do sistema consciente. (Freud, 1915).

No id, não existe nada que corresponda à ideia de tempo; não há reconhecimento da passagem do tempo, e - coisa muito notável e merecedora de estudo no pensamento filosófico - nenhuma alteração em seus processos mentais é produzida pela passagem do tempo. Impulsos plenos de desejos, que jamais passaram além do id, e também impressões, que foram mergulhadas no id pelas repressões, são virtualmente imortais; depois de se passarem décadas, comportam-se como se tivessem ocorrido há pouco. (Freud, 1932)

O sujeito é correlacionado a um desejo indestrutível e, embora não corresponda ao observável, pode-se afirmar que não há criança sozinha, pois não se pode ser causa de si mesmo. Segundo Lacan, uma criança não nasce sujeito; apenas quando tomada como objeto de amor e gozo de um 
casal, poderá vir a ter lugar como sujeito desejante, caso que não acontece nas psicoses.

A instituição de uma subjetividade, portanto, depende de que um homem e uma mulher possam funcionar além de suas funções procriativas como transmissores de uma herança simbólica que institui um lugar para o filho. Desde onde o filho será investido narcisicamente e correlacionado a significantes do ideal que the permitirão identificar-se e constituir sua historicidade.

O sujeito humano é o único dentre os animais que não admite uma morte sem sepultura, pois não identifica o humano com a carne, com o organismo. Embora apodreça, vire pó como diz a Bíblia, o sagrado, o imutável na cultura indica que todo homem tenha um lugar de descanso, lugar desde onde será falado: terá tido uma história.

Essa condição de historicidade se dá pelo fato de o homem ser marcado por um desejo, desejo inicialmente sustentado pelas figuras parentais e com o qual a criança se identificará trilhando seu porvir. Essa estrutura simbólica, que ultrapassa o domínio da procriação biológica, é instaurada pelo desejo da mãe e pela função paterna. A historicidade e localização do sujeito se dão no que Freud nomeou como Complexo de Édipo, mais uma estrutura do que fase de desenvolvimento.

O Édipo garante ao sujeito o acesso à individualidade, isto é, poder dizer "eu sou", operação que o situa além do organismo no eixo de uma humanização, pois articula o individual e o coletivo, o sujeito e o social. Lacan ressitua o Édipo como o Outro do sujeito, uma estrutura que antecede o sujeito por ser lugar da linguagem e cultura na qual a criança deverá inserir-se para tornar-se sujeito da fala.

Lacan situa o sujeito do inconsciente como um sujeito alienado no Outro não importando sua idade. Aproxima-se assim o adulto e a criança pela estrutura. Mas a criança situada na dependência do Outro, destituída da modalidade específica do gozo traz imbricações muito específicas quanto à questão da responsabilização do sujeito pelos seus atos no caso da SAP. Isso permitirá ressituar a SAP como tendo valor diagnóstico, pois 
a "criança", apesar de ser também um sujeito, encontra-se em constituição numa dependência particular e acentuada do Outro parental. Mesmo sendo um, está impedida de assentir no gozo promovido pela oferta alienante do genitor.

A subversão da proposição do objeto de estudo da Psicologia tomar o sujeito no lugar da criança, ao lado do conceito de infantil ocupa o centro da questão diagnóstica e terapêutica da psicanálise, permitindo extrair consequências diametralmente opostas na sua prática e ética. Sujeito e infantil são dois conceitos operadores que norteiam a clínica psicanalítica com quaisquer sujeitos não importando a idade, o que se afasta do senso comum, da noção de criança e infância.

A partir dos tratamentos dos neuróticos, Freud descobriu que a manifestação dos sintomas de seus pacientes aparecia como expressão de um conflito entre a expressão da sexualidade infantil e uma defesa - o recalque, que afasta do eu as representações intoleráveis. No curso do desenvolvimento, a atividade sexual infantil é interrompida pelo recalcamento sexual do desejo incestuoso dirigido a um dos pais. De acordo com Freud (1905/1989), "o indivíduo neurótico sexualmente maduro geralmente traz consigo, da infância, uma dose de recalcamento sexual que se exterioriza ante as exigências da vida real... e que seus sintomas têm valor de compromisso entre as duas correntes anímicas". (p. 260)

O infantil, na acepção da psicanálise, não equivale à infância porque se refere a um fator determinante da estrutura psíquica do sujeito. Designa o aspecto sexual recalcado que provoca a escolha de uma neurose, de um sintoma que perdurará na vida ulterior. Essa escolha se concretiza como estrutura do sujeito e seu peso será carregado para a vida adulta. Portanto o infantil está na base da neurose, uma vez que representa a permanência do sintoma na vida adulta.

O sintoma constitui-se como efeito da estruturação do sujeito pelo inconsciente a partir da operação defensiva do recalque diante da intrusão do sexual, oriundo da pulsão. Freud situa como força originária da 
sexualidade a pulsão, distinguindo-a do instinto, padrão hereditário filogenético que determina o objeto sexual, um padrão de relação para todos da mesma espécie. O conceito da pulsão permite a inserção do sexual num modelo de variabilidade infinita de objeto sexual devido à sua relação com o campo do desejo humano, desejo infantil e indestrutível pois inscrito no inconsciente.

Freud com isso demonstra a relação entre sexualidade, inconsciente e infantil. Neste tempo deverão ocorrer as manifestações pulsionais e seu recalque, instaurando o inconsciente a partir da marca primeira do desejo e da subordinação do sujeito a esse domínio. A pulsão como força motriz do desejo é instalado pelo Outro primordial, Outro pré-histórico, o Outro auxiliador que, ao inscrever a marca de uma ação específica, cessa a estimulação endógena e permite a experiência de uma satisfação ao infans impotente e instaura a divisão consciente/inconsciente desde onde poderá advir como sujeito. Lacan renomeia esse outro auxiliador como grande Outro para ressaltar que não se trata do outro tomado no registro do semelhante, da imagem, mas do outro como função de instalação do simbólico, pois o desejo humano não se dirige a um objeto empírico como a necessidade. Ele surge de algo que é expulso do Outro - sua parte opaca. É em torno desse primeiro exterior que se institui o encaminhamento subjetivo - o sujeito, na sua relação com a realidade vai ao encontro do objeto que é sempre perdido. O desejo constitui-se a partir desse encontro com o Outro cuja marca de gozo instaura uma experiência de castração, ou seja, o Outro absoluto é impossível ser achado, instaurando a lei da proibição do incesto:.

É isto o infantil freudiano: os traços do gozo do Outro, o que há de gozo ineliminável que o sujeito deve ao fato, senão de falar, pelo menos de consentir no significante. São esses traços que Freud designara com o termo fixação, de tacos de gozo, de além do princípio do prazer, de repetição... (Sauret, 1998, p. 21)

Freud identificou o impasse que nasce da relação da criança com o Outro materno como neurose infantil. Sauret (1998) esclarece esse impasse: "O sujeito não tem a garantia de que o Outro assegurará 
eternamente sua sobrevivência. O desejo materno aparece como caprichoso. Sua demanda toma a forma de uma vontade de gozo". (p. 20) Assim, a neurose infantil é o resultado do impasse que se instala na relação da criança com a mãe quando encontra o desejo desta.

Pode-se situar o infantil como o tempo em que uma interpretação do desejo do Outro se fixa numa modalidade de gozo, modalidade de satisfação que implica prazer e dor e se torna a matriz das relações do sujeito com outra matriz - o Outro primordial. Mas qualquer que seja a modalidade de gozo (oral ou anal) haverá sempre um impasse que leva o sujeito a apelar ao pai, o pai entendido como uma função.

... é um impasse que impele a fazer apelo a um elemento da estrutura exterior à relação com o Outro materno, o pai. Tal é a função desta vez do pai simbólico: humanizar o desejo da mãe. Pondo-o de acordo com a lei.... é uma mensagem que só o sujeito consentiu na solução significante.... A solução ao pai que o sujeito traz à crise infantil, incluindo as ditas fixações como índices de gozo, solução que passa ao inconsciente como fantasma fundamental. (Sauret, 1997, p. 21)

Dessa forma, já constituída a partir do lugar do objeto de gozo do Outro, ponto de masoquismo original do sujeito, a criança passa a situarse como sujeito desejante e inserido na ética que a psicanálise indica: por nossa posição de sujeito, somos sempre responsáveis. Essa noção de infantil impede que se tome a criança como naturalmente inconstituída, como passiva, como vítima, como assexuada, um ser puro, incapaz de fazer o mal e mentir quebrando um dos preconceitos oriundos da filosofia da educação rousseauniana, que concebeu a criança como um ente inocente, um anjo que só seria corrompido pelo social.

Tal concepção traz consequências clínicas e sociais, pois considerar o estatuto da criança como sujeito implica não tomá-la como vítima, o que negaria o lado criador que aparece quando o sujeito se responsabiliza pelo gozo para além de ser tomado como objeto pelo Outro. É nesse ponto que pela psicanálise pode-se criticar a noção gardneriana da criança na SAP como vítima e não responsável pela recusa e campanha difamatória ao genitor-alvo. Embora na estrutura a posição original da criança é a de 
objeto de gozo, ela se torna sujeito pela operação do Nome do Pai, que opera um corte no gozo materno e liberta a criança para o desejo. A criança pequena, ainda que incapaz de subjetivar um gozo próprio, é capaz de ler os significantes do Outro, ou seja, ela interpreta os pedidos da mãe, diferenciando-os de seu querer e apresenta uma resposta singular. Pode-se considerar que, mesmo quando um genitor faz uma campanha difamatória do outro que tem como resultado a rejeição, essa animosidade é já uma resposta da criança ainda que alienada ao discurso do Outro. A criança não pode, como sujeito, ser lida como puro reflexo do comando de seus pais - há sempre uma abertura para o novo. Isso permite entender por que algumas crianças são mais resistentes à instalação da SAP, abrindo portas para entender a intervenção.

A questão da SAP aponta para quando a criança subjetiva uma demanda que tem como consequência um gozo pelo qual ela não pode responsabilizar-se, mas que consentiu. Contudo, se postulamos que a criança aquiesce ao gozo do genitor alienador, isso não significa que não se pode igualar a responsabilização da criança à do adulto programador na SAP.. Constatam-se na clínica com SAP diversos tipos de respostas de alienação da criança à programação sistemática do alienador. Nesse sentido, há uma variedade de formas de respostas que escapam à ideia classificatória de Gardner de SAP.

Um menino de 6 anos, diante de uma programação intensa e violenta da mãe, não difamou nem recusou a companhia do pai, mas apresentou uma inibição. Diante da programação da mãe e de seus ataques de fúria, o filho ficava mudo e a nada respondia. Não se aliava à mãe nem deferia raiva contra a mesma, o mesmo em relação ao pai.Noutro caso, uma criança fez uma campanha difamatória do pai sem uma programação sistemática da mãe, apesar de esta última sentir mágoa do pai. Neste caso, os elementos da alienação eram provenientes em grande parte da própria criança.

Uma mãe fazia uma programação severa, os filhos por sua vez passaram a recusar o contato com o pai sem realizar uma campanha 
difamatória, tiveram uma reação esquiva e mais passiva sem que pudesse ser classificada nos moldes de uma SAP. Apesar das diferentes respostas frente à programação, frente ao imperativo superegoico do Outro, a criança apresenta uma resposta particular, portanto como sujeito.

A partir da influência do estruturalismo, Lacan propôs uma clínica cujos elementos operativos são os mesmos em qualquer idade, o que não significa dizer que a psicanálise dispensa adaptações à prática com crianças. Com o infantil, rejeita-se um conhecimento prévio, uma influência moral, pedagógica ou educativa e aponta-se que a criança nem mesmo equivale ao que os pais dizem delas. Ao se considerar no lugar da criança um sujeito, constata-se que o discurso da criança definitivamente não é o mesmo que o discurso de seus pais sobre ela.

Gardner em sua descoberta clínica relata que na SAP há falsas memórias, sentimentos e falas, tornando equivalente o sintoma no adulto e na criança (tomando as respostas um reflexo muito próximo das atitudes do programador). Ora, a psicanálise distingue não só a dimensão da fala e do discurso como também a posição subjetiva, pois, embora fenomenologicamente se constate uma mesma fala entre criança alienada e genitor alienador, em dois sujeitos não se pode estabelecer uma correlação pura e direta. É necessário, portanto, debruçar-se sobre a resposta particular da criança como sujeito quando diante de uma programação, para que se possa intervir a partir da noção de um sujeito e não da criança tomada como objeto.

No entanto, por outro lado, ao tratar a criança como vítima, Gardner propõe que as manifestações difamatórias, quando oriundas de programação, não sejam tomadas como genuínas. Que o operador saiba diferenciar que nem sempre uma manifestação de vontade da criança deve ser atendida e tomada como verdadeira no nível do desejo e do reconhecimento de um sujeito, pois ela não pode ser responsável por sua posição de gozo. Trata-se de uma intervenção em que a fixação desse gozo pode prejudicar sobremaneira o porvir da criança. Ainda que sujeito, ela encontra-se na dependência do Outro até a adolescência, quando dele 
efetivará uma separação radical, que Ihe permitirá responder pelos próprios atos, tornando-se então um adulto. Essa operação permitirá que ela afrouxe sua posição sintomática decorrente da fixação pulsional que Ihe permitia obter satisfações substitutivas no lugar do objeto perdido, isto é, modalidades de satisfação pulsional autoeróticas e narcísicas.

Dessa forma tem-se que situar a criança "neurótica" também como agente de sua história e seu assentimento ou não ao desejo ou gozo. Mas isso não quer dizer que ela seja um sujeito que pode responder pelos atos, que é o que faz a diferença no campo jurídico quanto à responsabilidade penal e também o que se tem que considerar em toda práxis que se dá no âmbito da família, da criança e adolescente. Quando se utiliza na clínica com crianças o conceito de sujeito, tem-se que considerar seu ponto de ancoragem na estrutura, ou seja, qual etapa de separação do Outro parental foi efetuada pela criança: se ela já fixou uma modalidade de gozo próprio ou ainda está na dependência do Outro, alienada num gozo imaginário e, portanto, muito suscetível à programação.

\subsubsection{A família, um dos nomes do Outro do sujeito}

O conceito de sujeito e infantil tem como corolário que o desenvolvimento se dá na estrutura, isto é, o desenvolvimento previsto pelo ciclo biológico vital depende da estrutura - uma matriz que inclui tanto a lógica do significante como a operatividade do objeto. Lacan nomeia essa estrutura como Outro e indica que o sujeito é o efeito da ação estruturante da estrutura. Esse pressuposto explica por que o indivíduo/criança determinado por uma organização biológica depois de um surto perde a capacidade cognitiva e de aprendizagem mesmo sem ter havido uma lesão anatômica, uma lesão funcional ou uma alteração da condição social.

A estrutura é o Outro do sujeito - uma matriz simbólica vazia que inclui o objeto a - operador do gozo que suplementa essa falta no Outro. 
O objeto em psicanálise não é um objeto do mundo, mas um objeto da fantasia inconsciente que indica ao sujeito um possível gozo a partir do simbólico, da linguagem, de forma que não tenha que oferecer o próprio corpo e seu ser em sacrifício para tamponar o furo do Outro. Esse objeto é inscrito na fantasia a partir da resposta à pergunta "O que o Outro quer de mim?" e leva à construção de um saber próprio que o separa do Outro.

Assim é importante elucidar como o objeto e o saber são oferecidos para a criança, pois desde aí se coloca a resposta do sujeito que se encontra numa total dependência do Outro. Por isso a posição subjetiva do Outro parental diante da criança, em particular o modo como se dá a oferta do saber e objeto, pode ter efeitos devastadores sobre o sujeito ou ser impossibilitadora de uma vida criativa.

Na SAP tem-se que considerar também os pais - Outro parental, pois como agentes são sujeitos além da criança, ambos inseridos no princípio ético da psicanálise que indica que: "por nossa posição de sujeito, sempre somos responsáveis" (Lacan, 1966/1998, p. 873).

Sauret (1998) observa: "No fundo, essa criança tende a colar a forma como ela é recebida no fantasma do Outro parental". (p. 32) Por sua vez, essa relação não se revela tão simples assim. Pode-se dizer que o fantasma opera diferentemente, conforme esteja ou não regulado pela função paterna. Nesse sentido, quanto menor a mediação realizada pela função paterna entre o ideal do eu e o desejo da mãe, mais a criança tenderá a ser capturada na fantasia da mãe, ocupando a posição de objeto condensador de gozo para esse Outro.

Parte-se do ponto de que, no inconsciente, o objeto do desejo inscreve-se como perdido, que na estrutura há uma falta central que comanda os representantes da pulsão nomeada como castração. Ou seja, há uma falta no Outro da criança e ela é chamada a vir completar como objeto de gozo, objeto de posse de um outro que se evade do confronto com a própria castração ao alojá-la com tampão do furo, negando a condição desejante da criança. Por isso, é muito importante distinguir a enunciação do enunciado do genitor, pois frequentemente esses 
cuidadores utilizam o discurso do amor para encobrir seu gozo em relação à criança. Esse ponto é crucial nas decisões dos Operadores do Direito quando se referem ao relato da criança acerca do genitor, em especial nas diversas alegações de abuso descritas a partir dos sentimentos evocados e da verdade intuída no relato.

Sabe-se pela psicanálise que o sentimento mente, frequente nos casos de grandes amores que se reviram em ódio e cuja conviç̧ão em um relato é mais da ordem da crença do que indicador da verdade, pois são desmontados quando se revela o núcleo fantasmático que dirige a percepção do sujeito, uma vez que a realidade do sujeito é sempre fantasmática. Se o Outro parental apresenta em sua fixação fantasmática a criança como seu parceiro de gozo, esta, com grande conviç̧ão e veracidade no relato, apresentará como sua realidade a fantasia do Outro.

O Outro parental coloca para a criança além do desejo e gozo, o ideal, significantes, e demanda através da fala e da linguagem. O Outro, além de desejante, apresenta um discurso com significantes com os quais a criança se identifica, produzindo, através desse laço com o Outro, a realidade psíquica. O Outro parental, sendo a primeira figura que dá sustentação para o laço social, permite que uma subjetividade se institua. Como o sujeito não tem acesso direto ao desejo, tomará os significantes do discurso do Outro para balizar sua direção em relação ao objeto do desejo, constituindo o campo da demanda.

A demanda nasce do desamparo em que se encontra o infans no campo da necessidade oriunda do biológico, do organismo que depende que o Outro interprete seus gritos/choros para supri-la. O Outro oferece objetos para a necessidade a partir do seu desejo e, portanto, com sua marca sexual, e ao bebê só cabe aceitá-la, pois do contrário enfrenta risco de aniquilação.

Esses objetos que correspondem às cinco formas de perda que Freud indica em "Inibição, sintoma e angústia" (1996/1924[1925]) correspondem à definição da função do objeto com os estádios de suas mutações que liga o sujeito ao Outro. É desse objeto de gozo que a 
constituiu que criança tem de separar-se para encontrar a via de seu desejo e que o genitor, na SAP, pode vir a funcionar de modo impeditivo.

A demanda tem relação não só com o objeto, mas também com os significantes do Ideal do Outro, ponto desde onde a criança se vê como amável e que também encobre a posição da criança como objeto de gozo. O ideal, quando conjugado com o objeto, impõe a via sacrificial ilustrada claramente nos jovens japoneses conhecidos como kamicazes na segunda guerra, que faziam da própria vida a arma/objeto que aniquilaria o inimigo do Imperador. Também em nome do amor, muitos genitores demandam que a criança tenha sua vida desejante sacrificada para cumprir um ideal de vingança como ocorre na SAP. A articulação da demanda com o significante que encobre o gozo impede que os profissionais discriminem a via do discurso da via do amor, que se situa a partir da falta e da distinção entre o desejo e o querer. Na SAP, frequentemente, o genitor sustenta que apenas respeita a vontade da criança, fazendo um levante contra o outro genitor, demitindo-o de sua função.

Toda essa montagem da realidade psíquica, que parte da falta central - a castração onde o objeto falta - vindo a ser recoberta pelo desejo e pela demanda, é um produto de uma linguagem que, como verdadeiro tesouro de significantes, é transmitida à criança pelo Outro, linguagem - materializada no fantasma - e que organiza na criança a realidade do sexo, atualizando-se por meio das futuras escolhas profissionais, relacionais, sexuais e afetivas.

Os pais ao ter um filho podem tomá-lo a partir do desejo (assunção da castração) ou do gozo como objeto tampão e elisão da castração. Tendo um filho a partir do desejo sempre se constatam votos de que os filhos sejam de uma determinada maneira. Mas esses votos do genitor, ainda que carreguem a marca da castração, são traduzidos em significantes que podem ser oferecidos como um saber absoluto do qual a criança não pode prescindir sem que perca o amor do genitor e caia da condição de amável. 
O discurso do genitor na SAP apresenta significantes isolados da rede simbólica que têm valor de mandato, eliminando o desejo de origem presente no outro genitor, pois, de outra forma, esse ideal se relativizaria e o filho não teria outra saída, para ser reconhecido e amado, senão oferecer-se para realizar esse ideal conjugado ao gozo.

Essa demanda do pai/mãe/cuidador endereçada à criança se dá de forma a situar uma única possibilidade identificatória, tomar o siginificante enunciado ao pé da letra sem simbolização, pois o enunciador está em posição de mestre, aquele que sabe do ser do sujeito. Por isso uma criança pode apresentar um enunciado que, mesmo sendo eco do discurso do genitor alienador, dele se torna fiadora e com grande convicção assume sua responsabilidade ainda que não haja nenhuma enunciação. Para o operador de Direito, isso é indicador de verdade, pois ele desconhece a diferença de saber e conhecimento. O saber é sempre uma elaboração do sujeito, uma simbolização e como tal carrega a marca da singularidade, não podendo nunca ser mimético ao de um outro. Esses significantes isolados do contexto simbólico da linguagem assumem a forma de um imperativo superegoico ao qual a criança deve responder para continuar sendo amada.

A psicanálise situa a criança na dependência do Outro, destituída de uma modalidade específica de gozo e, portanto, com imbricações muito específicas quanto à questão da responsabilização do sujeito pelos seus atos. Por isso pelos direitos da infância e juventude decretados na Convenção Internacional de 1989, a criança é diferenciada do adulto por ser portadora de necessidade de proteção por sua condição vulnerável e irresponsável, por não ter a autonomia do adulto. A entrada na vida adulta supõe um sujeito capaz de responder pelos seus atos porque seu sintoma articulado ao fantasma e à separação necessária do Ideal do Outro lhe permite escolher responder ou não à demanda do Outro.

A constituição do sujeito implica uma temporalidade na qual se dão experiências de separação que permitem à criança constituir um saber próprio ao ir lendo as pistas do desejo do Outro de forma a assentir ou 
não no gozo transmitido. Assim, não se pode tomar a criança como puro objeto passivo, vítima, ser inocente e irresponsável, pois constata-se na clínica e na vida que, mesmo pequenina, ela pode apresentar respostas singulares e não somente respostas alienadas ao discurso do Outro. Isso não só justifica as crianças que não respondem à SAP de um genitor, pois fizeram separações que Ihes permitem rejeitar esse gozo mortífero para seu desejo, mas também tem implicações no campo sociojurídico: faz-se eticamente necessária a intervenção do Estado, como representante da ordem simbólica, da lei que regula o gozo em casos em que há falência das funções parentais, podendo levar a criança à devastação.

Ainda que se aceite a crítica a Gardner por vitimizar a criança, negando sua condição de sujeito, não se pode deixar de ressaltar que ele resgata esse ponto lógico do desenvolvimento na estrutura na qual a criança ainda não pode responder pelos seus atos. Ele indica que ela não apresenta pensamentos, falas, sentimentos e comportamentos genuínos ou autônomos na recusa ao outro genitor, mas indica também que se essa rejeição for genuína, não se aplica o diagnóstico de SAP. Ou seja, Gardner constatou clinicamente que não é a partir do desejo, de sua posição de sujeito, que a criança apresenta animosidade ou recusa ao genitor alienado na SAP, mas sim por estar na dependência do Outro e por não ter ainda modalidade de gozo próprio. Dessa forma, responderá à demanda insistente do Outro. Também indicou que é possível que uma criança seja capaz de responder genuinamente mesmo sendo uma recusa, ou seja, ela estaria separada do gozo do genitor.

Nesse ponto lógico do desenvolvimento de dependência total do Outro, o sujeito necessariamente terá de responder à demanda do Outro, pois é fato de estrutura que a fala vigora entre dois para que se evoque o desejo. Sem passar pelo campo da demanda, não há possibilidade de pensar o sujeito, por isso a questão que pode ser trazida a partir da teoria da SAP é: qual tipo de resposta à demanda o sujeito produziu?

Em 1914, Freud, no seu texto "Introdução ao Narcisismo", situa o lugar da criança na cena familiar, situa os pais como alvos dos fantasmas 
da criança, a criança como objeto dos investimentos libidinais dos pais e também destaca o papel ativo dos pais na sexualidade dos filhos.

O que Freud descreveu como instalação e dissolução do Édipo na infância é o que Lacan redefiniu como a relação do sujeito com o Outro. Na releitura do Édipo freudiano, em "Os Complexos Familiares na Formação do Indivíduo" (1938/1993), situa o pai e a mãe como funções essenciais à constituição do sujeito e suportadas por agentes da realidade imprescindíveis ao processo.

Lacan sublinha em "As Relações de Objeto" (1956-57/1995) a importância tanto da presença dos pais como o discurso do Outro, como o discurso que os pais encarnam e que situa o lugar da criança na família.

Em "As formações do inconsciente" (1957-58/1999), ele aponta que o Outro é tanto a matriz simbólica que antecede o nascimento do sujeito, como função que porta significantes que permitirão à criança realizar identificações que a conduzirão à assunção de seu desejo e devir sexuado. A inserção da criança nessa matriz edípica dependerá, portanto, do discurso que Ihe servir de referência para a criação de sua ficção (romance familiar) e para fazer as identificações que lhe permitirão um futuro onde poderá efetivar as escolhas amorosas, sexuais e profissionais.

\subsection{GÊNESE E ESTRUTURA DA SAP}

\subsubsection{Alienação fundamental e alienação na SAP}

Ao ressituar o Édipo freudiano através da operação de alienação e separação no Outro, Lacan considera o Outro como lugar e função e o sujeito causado por essas operações lógicas (1964-65/1988). Portanto, o Outro do sujeito é uma fiç̧ão por ele criada para que possa sustentar sua causação. Para que esse Outro se constitua como origem, causa do sujeito, 
deve ser sustentado por agentes da realidade que ao tomar o infans como objeto de seu investimento libidinal, por que não amor?, orientam seu desejo.

A alienação, segundo a acepção psicanalítica, aparece como conceitochave para o entendimento da Síndrome de Alienação Parental. A tese lacaniana de que a alienação é fundamental, destino de todo sujeito, permite compreender por que a SAP obtém sucesso em se instalar na criança. A eficácia da alienação intentada pelo genitor alienador decorre do fato de ela recuperar ou sobrepor-se a um processo normal, a alienação fundamental e constitutiva, mas com exageração. No entanto, por ser o conceito de alienação regra final para toda e qualquer compreensão psicanalítica do patológico, pouco ajuda na compreensão da precisão da gênese e estrutura da SAP, fornecendo apenas o entendimento para seu sucesso.

Portanto a perturbação da vinculação da criança com os genitores presente na SAP será posteriormente precisada através do conceito de transferência. Se do lado do genitor alienado marca-se uma hostilidade acentuada e até mesmo a ruptura completa da relação; do lado do genitor alienador, nota-se um reforçamento da alienação e idealização da relação do sujeito como seu Outro.

Sendo a transferência aquilo que permite o laço social ao sujeito, a tese freudiana sobre a transferência junto à releitura lacaniana permite formalizar a questão genético-estrutural em jogo na SAP. Esse conceito será articulado como aquilo que incide na modificação da transferência da criança com os genitores e instaura um discurso e que visa excluir ou denegrir o genitor alienado do lugar de Outro na criança.

Para esta segunda articulação, será preciso, portanto, decompor alguns elementos formativos da transferência que se entende participar da formação da SAP - identificação, idealização, fantasia, sugestão -, que permitem a SAP articular-se na criança. Trata-se de identificar a posição subjetiva da criança ao discurso do alienador para explicitação da tese em questão. Entretanto, a SAP não se resume a uma forma de identificação, 
idealização, sugestão ou fantasia, mas a uma conjuntura específica na reunião desses elementos.

Há que se demarcar uma diferenciação entre a alienação fundamental e necessária para a constituição do sujeito descrita por Lacan em "Os quatro conceitos fundamentais da psicanálise" (1964/1988) e a alienação presente na SAP.

Na SAP, visa-se produzir uma alienação na criança ao discurso do genitor. Sua finalidade é determinada - excluir não apenas a presença, mas o papel e função de um genitor. Gardner descreve na SAP um processo de alienação que rejeita um dos lados essenciais da constituição do Outro da criança, pois visa construir uma única referência para ela, através de um discurso no qual só tenha validade o desejo, ideais e demandas de apenas um dos elementos do casal parental, com a exclusão ou minimização da função do outro genitor.

É nesse ponto que as contribuições de Lacan podem fundamentar a práxis no campo jurídico, explicitando o que seria uma alienação necessária e fundamental ao processo de constituição subjetiva e o que seria um projeto de alienação engendrado com fins de excluir o outro genitor do lugar de agente do discurso que agencia os significantes do ideal para a criança.

Por conseguinte, nos campos da linguagem e do gozo, o desenvolvimento cede lugar à historia a partir do encontro com o Outro desejante, que cunha no aparelho psíquico a marca do encontro traumático do sexual - o incurável do sujeito. Essa relação do sujeito com o Outro, pela qual um vivente se submete ao campo da linguagem advindo como sujeito pelo poder do significante que o designa, depende da encarnação da figura do Outro por um ser desejante - um cuidador. Isso permitiria a subjetivação de duas operações constitutivas da subjetividade: alienação e separação.

Para Lacan a alienação é o destino do sujeito por estar ligada ao momento de sua constituição, quando se dá a ação do significante que humaniza o desejo e retira o sujeito do limbo do vazio, fundando e impedindo sua identidade com a carne. A alienação do sujeito ao significante 
é umas das vertentes que Lacan trabalha em sua obra e que permite compreender o processo da SAP.

Não há ser humano fora da linguagem. E linguagem não se resume ao verbal. O infans não fala, mas nasce imerso na linguagem. Ele é falado por seus pais antes mesmo que fale. Sua existência é sustentada antes que ele venha ao mundo. Nesse sentido Lacan postula que há um lugar para o sujeito, anterior ao seu nascimento, no desejo do Outro. Lugar desde onde ele responde às expectativas parentais para que possa constituir-se, fazerse desejável e fazer-se ser amável. Se esse lugar de miragem existe antes mesmo do sujeito, é por isso que os filhos nunca são aquilo que os pais acham que são ou deveriam ser. É nesse descompasso que emerge o sujeito.

O Outro parental, desejante em sua relação com o infans, deixa marcas como resultado desse cuidado, marcas de gozo na criança que também recebe marca do desejo dos pais: desejo que aponta um vir-a-ser, um futuro por realizar-se. Assim, as falas desses primeiros cuidadores constituem um discurso - o discurso do Outro, que aponta representações ideais expressas através de palavras da língua nomeadas de significantes por não terem significados atrelados, constituindo o campo do Ideal desde onde a criança buscará identificar-se para tornar-se amável ao Outro. A relação da criança com o discurso do Outro implica que esse Outro forneça significantes, que constituem o campo da demanda articulada ao amor pois que esse Outro só pode conceber um filho a partir do próprio narcisismo infantil perdido que tentam recuperar mediante a idealização de seus filhos. Freud indica que a criança é sempre "sua majestade, o bebê", objeto amado por ser a revelação do narcisismo primário abandonado dos pais e possibilidade de revivência do eu-ideal renunciado.

Ao filho não resta senão responder alienando-se nos significantes que o Outro Ihe fornece para ser desejado-amado. Nesse sentido, a alienação no Outro é fundamental para que o sujeito constitua-se como tal.

O conceito de alienação é retomado e desenvolvido ao longo da obra lacaniana por ligar-se à noção de constituição do sujeito, tendo sua primeira 
aparição no texto "O Estádio do espelho", em 1949. Lacan apresenta a hipótese de que o sujeito não existe desde o início, que ele se institui num dado momento através de um ato - um ponto inaugural, marco zero do sujeito. Para sair do desamparo inicial, o ser humano fixa-se numa imagem que o aliena em si mesmo, a qual ele irá chamar de eu. Essa experiência, na medida em que essa imagem pregnante é investida libidinalmente, está relacionada com o universo simbólico que vem respaldá-la - o Outro que confirma à criança essa apreensão que, definida desde uma exterioridade, constitui o eu como uma imagem unificada, antecipando o domínio motor, pois ainda vivendo uma incoordenação própria do desenvolvimento. A apreensão da imagem ideal compreende um congelamento que fornece o aspecto unificado do corpo e também uma primeira matriz na relação intersubjetiva. Lacan nomeia essa assunção da imagem ideal, na qual o eu se conforma, de identificação especular pois cobre a fantasia do corpo fragmentado e produz reações passionais frente à satisfação ou perda do que é investido libidinalmente. Aquilo com que o sujeito se identifica revelase para ele através de uma ligação amorosa e apaixonada que, no entanto, justamente por ser uma imagem "outra", desperta nele sua ira, seu ódio. A identificação se dá em razão da alteridade contida em seu mecanismo - ao Outro e ao eu é dada uma identidade na medida em que esta não passa de uma ilusão proveniente de uma soldagem entre o eu e a imagem.

O estádio do espelho representa a estrutura da dinâmica narcísica, as leis de funcionamento do eu, conforme apontada por Freud, não sendo, portanto, uma fase ultrapassável. Sua estrutura consiste de uma simultaneidade da constituição do eu e da perda que aí se instaura ao mesmo tempo: a discordância e a distância fundamental do eu com sua imagem. Há uma hiância incolmatável entre eu e imagem decorrente de que o eu se constitui como um Outro, revelando a toda a dimensão da linguagem como mediadora e que dá valor de existência à constituição da imagem do eu, ou seja, do próprio eu.

A alienação ao Outro, tomado no registro do imaginário e do simbólico pois que representa uma antecipação e assunção de uma imagem, a partir 
da qual o sujeito assume uma totalidade imaginária conformando o eu, alavanca o ponto inicial de edificação de um sujeito. Há um engodo, próprio da alienação, ao acreditar resumir todo seu sujeito nesse eu, pois ao eu é dada uma identidade na medida em que esta não passa de uma ilusão proveniente de uma soldagem entre o eu e a imagem, a identificação não é identidade.

Lacan afirma ser esta uma identificação alienante, que marcará com sua estrutura rígida todo o desenvolvimento mental. Essa imagem advém do Ideal, da visada dos pais do infans. Por isso será o Ideal, o simbólico, que comandará o destino da imagem, ou seja, a alienação imaginária coloca-se na dependência da alienação simbólica. O simbólico garante o que transcende para que o sujeito não se consuma em si mesmo, institui-se assim o outro como Outro, garantindo a não-alienação para sempre em sua imagem, reflexo de si mesmo. O Real aparece aqui como a totalidade ou o instante esvanecido (Lacan, 2005, p. 45) atrelado ao Simbólico. Esclarecese, assim, que a alienação do gozo da imagem coloca-se numa relação com a entrada do significante do Ideal. Pode-se perceber esse gozo narcísico da imagem em certas situações de SAP em que o genitor alienador reforça para o filho o domínio do imaginário e abranda o simbólico.

Lacan ressituou a alienação apontando que do Outro primordial emerge a insígnia que constitui o Ideal de Eu, apoio das identificações do sujeito. Mas, a partir do seminário XI, Lacan inverte o esquema, ao introduzir a operação de separação e afirmar que o inconsciente é um conceito forjado no rastro daquilo que opera para constituir o sujeito.

Com o sujeito, portanto não se fala. Isso fala dele, e é aí que ele se apreende... pelo simples fato de isso se dirigir a ele - desaparecer como sujeito sob o significante em que se transforma, ele não é absolutamente nada. (Lacan, 1998/1960-64, p.835)

A ênfase colocada no nada, no vazio como ponto de partida do advento do sujeito, o levará a postular que a resposta vem primeiro e o sujeito surge como ação significante. Ou seja, primeiro o sujeito encontra sua equivalência no que ele é como sujeito do inconsciente no desejo do Outro, via pela qual ele se realiza na perda em que surgiu como 
inconsciente, pela falta que produz no Outro. O sujeito aí não se faz significante, mas sim objeto.O sujeito faz de seu desaparecimento o objeto do Outro.

O primeiro objeto que propõe a esse desejo parental, cujo objeto não conhece, é a sua própria perda - Pode ele me perder? A fantasia de sua morte, de seu desaparecimento, é o primeiro objeto que o sujeito tem para colocar em jogo nesta dialética... Sabemos também que a criança evoca frequentemente a fantasia de sua própria morte nas suas relações de amor com os pais. (Lacan, 1985, 1963-64, p. 203)

Trata-se de situar agora duas faltas no Outro e no sujeito, no Outro do significante há uma falta e no campo do sujeito também, duas faltas que se recobrem. O sujeito, então, deve fazer escolhas: ou a cadeia significante ou o vazio. Lacan elabora esse momento em que se funda o sujeito através da analogia do encontro com o bandido quando o sujeito deve escolher entre a bolsa ou a vida. Ele deve perder a bolsa para que possa ganhar a vida. Trata-se de uma escolha, mas uma escolha forçada - o aceite do sujeito à oferta do Outro para que possa constituir-se como tal. De acordo com Nascimento (2010):

...linguagem que o precede... Uma linguagem cujas regras e códigos estão já definidos, não tendo tido o sujeito nenhum papel em sua constituição. Essas leis lhe são exteriores, e é preciso conformar-se a elas caso se queira obter reconhecimento do Outro falante. Com efeito, será esse Outro que o ensinará a servir-se da linguagem, Outro que fornecerá todos os significantes necessários a tal utilização. ( $p$. 1).

Antes que o sujeito seja representado por um significante que foi ofertado a partir do Outro, não existe sujeito. No entanto o sujeito sofre uma petrificação ou mortificação quando faz sua escolha. Ele aceita a determinação do Outro antes que possa ser determinante. O sujeito passa então a ser representado por um significante, num ato de aceite, ao significante que vem do Outro. O significante enlaça o Outro e o sujeito, alavancando o ser da indiferenciação do real à condição de sujeito na linguagem. Nesse sentido, Outro é definido por Lacan como a primeira causa do sujeito. 
Nesse sentido pode-se pensar a SAP como uma situação que não contempla a contingência da perda, porque não permite a pergunta: pode ele me perder? Já que a criança é tomada, não no registro do desejo, mas da posse, tão bem ilustrada na parábola do rei Salomão diante das duas mães. Para isso, o genitor apresenta um Outro consistente, uma vez que a criança se torna seu tampão, instituindo uma situação de puro gozo que impede a aparição do sujeito desejante na criança. "O desejo do outro é apreendido naquilo que não cola, nas faltas do discurso do Outro, e todos os por quês?" (Lacan, 1985/1963-64, p. 203)

Essa operação a partir da qual se extrai o objeto - esse nada que institui o sujeito - permite constituir a fantasia e a realidade psíquica, que será suporte do desejo. Assim, o sujeito só pode ser situado para além da redução dos ideais da pessoa.

...é como objeto do desejo, como aquilo que ele foi para o Outro em sua ereção vivente, como o wanted ou o unwanted de sua vinda ao mundo, que o sujeito é chamado a renascer para saber se quer aquilo que deseja. (Lacan, 1998/1960, p. 683)

Na SAP a criança estaria impedida de saber se quer aquilo que deseja, pois estaria presa num Outro consistente do qual não teria leitura, uma vez que o cuidador se propõe a elidir o campo da falta do Outro tornando a criança sua cúmplice do gozo. Daí apresentar demandas absolutas, quer dizer, uma demanda que não permite situar a falta, pois que se apresenta não para ser lida, mas para ser obedecida, ou seja, um pedido que toma a face de um mandato, uma vontade de gozo.

A noção de sujeito lacaniano não corresponde a uma substância, mas a um efeito do significante. A tese lacaniana de que o significante é o que representa o sujeito para outro significante resume o fato de que o sujeito é alienado na linguagem uma vez que a ordem simbólica o constitui. Antes que o sujeito possa dar representação simbólica a alguma coisa, ele foi representado por alguém (Outro) através de um significante. A significação que o sujeito atribui às coisas é posterior ao momento em que ele aceita receber os significantes do Outro os quais petrificam sua existência no 
atributo do ser. Sua significação da realidade é, portanto, alienada, pois em primeira instância passa sempre pelo Outro. A alienação é o destino do sujeito.

Portanto o Outro e o sujeito são faces da mesma moeda. Segundo o axioma lacaniano: "o inconsciente é o discurso do Outro", não há sujeito do inconsciente sem o Outro. O Outro é o lugar ao qual o sujeito endereça sua mensagem, o lugar da demanda, uma vez que é via pela qual o sujeito pode se confrontar com a falta no Outro e aceder ao desejo. De acordo com. Prates (2006), "é essa a questão com a qual o neurótico tem que se haver em seu processo de análise, ou seja, que ele não tem escolha, a não ser a de responder pela frase que começou antes dele ..." (p. 137). O sujeito lacaniano é assujeitado à estrutura do Outro. "Assujeitado, mas não escravo, pois desse Outro ele deve separar-se, parir-se, engendrar-se, criarse, enfim". (Prates, 206, p. 140)

Ser o sujeito só pode ser constituído a partir do lugar do Outro, o tesouro dos significantes é porque o sujeito não pode ser causa de si. E por isso ele deve passar pelo viés do Outro, esse Outro fictício que se confunde com o outro cuidador, para poder construir uma relação com o mundo. Tese de Lacan que se iniciou com a alienação especular em que o "o eu é Outro", indicando que as relações com os semelhantes não podem senão passar pelo Outro. Assim, Outro e sujeito ligam-se através da alienação:

O sujeito como tal só pode ser conhecido no lugar ou locus do Outro. Não há meios de se definir o sujeito como consciência de si... De fato, não podemos conhecer a nós mesmos como sujeitos; não existe autoconsciência de nós: somos obrigados a nos conhecer por meio dos outros. (Laurent, 1997a, p. 34)

A união do sujeito com o Outro deixa uma perda: se o sujeito tenta encontrar-se no Outro, só pode se encontrar como uma parte perdida. Ele fica petrificado por um significante-mestre e perde alguma parte de seu ser.

A alienação, isto é, o fato de que o sujeito, não tendo identidade, tenha de se identificar-se a algo encobre ou negligencia o fato de que, num sentido mais profundo, o sujeito se define não apenas na cadeia significante, mas no nível das pulsões, em termos de seu gozo em relação ao outro (Laurent, 1997b, p. 43). 
A alienação fundamental, por se tratar da origem do sujeito, desdobra-se em uma alienação do sujeito na sua imagem e uma alienação do sujeito ao significante do Outro Ideal - a alienação simbólica. Em 1964, ao avançar situando o par alienação-separação a partir da distinção do real e do simbólico como categorias, Lacan marcou também uma virada no conceito de sujeito.

A alienação inclui a alienação imaginária e alienação simbólica, mas com um desenvolvimento que pressupõe no núcleo do Ideal um significante particular - o significante S1 que comanda toda a cadeia significante e é distinto do objeto a, operador do real na estrutura. Esse significante que comanda a cadeia é o que Freud designou como traço unário, mas concebido agora como significante excluído da rede simbólica permitindo esse vazio, lugar original do sujeito, o mais próximo do âmago do sujeito, pois revela seu gozo opaco e ao mesmo tempo permite constituir uma constelação de insígnias que compõem o ideal do eu para o sujeito.

Assim, a alienação e a separação são figuras que Lacan usa para articular significante e gozo, propondo privilegiar a causação do sujeito em detrimento do conceito de inconsciente. A constituição do sujeito redefinida como uma operação de causação do sujeito decorre da operação de alienação concebida como a abertura simbólica ao Outro e corresponde ao momento no qual o sujeito emerge no campo do Outro e da operação de separação que corresponde à resposta de gozo e ao fechamento real ao Outro.

A alienação é uma característica essencial de toda subjetividade, por isso Lacan cunhou o vocábulo "extimidade" (externo e íntimo) para designar a natureza dessa alienação, na qual a alteridade habita o núcleo mais íntimo do sujeito. O resultado da operação alienação, que é contração da identificação e do recalque e permite colocar como resultado da operação significante o sujeito barrado, ou seja, o sujeito desejante. Mas o sujeito não pode ser inteiramente representado no Outro; sempre há um resto - se o sujeito tenta encontrar-se no Outro, só pode se 
encontrar como uma parte perdida. Ele fica petrificado por um significante-mestre e perde alguma parte de seu ser. O sujeito então encontra algo que se desprega do Outro e que é fora do sentido - o objeto a, esse nada que permite ao sujeito advir.

O Outro implicado na separação não é o Outro cheio de significantes; ao contrário, é um Outro a quem falta alguma coisa. $\mathrm{Na}$ interseção entre o sujeito e o Outro, há uma falta, por isso a separação tem uma condição: o encontro com a falta do desejo. O sujeito é falta, pois perdeu seu ser. Nessa intersecção, o que está presente e o que se superpõe é a falta do desejo (a falta do Outro) e o ser perdido do sujeito.

A alienação é própria do sujeito porque ele nasce por ação da linguagem de um cuidador, um outro, enquanto ocupa o lugar de Outro, oferece significantes através da fala, aos quais o sujeito se submete - a alguns dentre os vários significantes. Mas seu ser não pode ser totalmente coberto pelo sentido dado pelo Outro, joga-se aí uma espécie de luta de vida e morte, entre o ser e o sentido: se o sujeito escolhe o ser, perde o sentido, e se escolhe o sentido, perde o ser e produz-se a afânise, o desaparecimento do sujeito. Nessa, não importa qual seja a escolha operada, se terá como consequência nem um, nem outro. Para Lacan, "... antes de ... desaparecer como sujeito sob o significante em que se transforma, ele não é absolutamente nada. Mas esse nada se sustenta por seu advento, produzido agora pelo apelo, feito no Outro, ao segundo significante". (1960/1998, p. 849).

Ou seja, o sujeito identifica-se com o traço significante aportado pelo Outro materno o que implica que é capturado pelo significante. É nesse sentido que pode-se apontar um reforçamento da alienação na SAP, pois o cuidador, que encarna o Outro, continua oferecendo significantes e imagens visando capturar a criança como complemento de sua falta para elidir sua castração. Dessa forma, qualquer cuidador pode utilizar essa operação constitutiva de todo sujeito com finalidade de exclusão de um genitor do processo de subjetivação da criança, passar-se a encarnar o Outro consistente e enunciar demandas com caráter absoluto às quais a 
criança tem que responder para ser amada ou para não perder o amor, prejudicando o curso da separação estrutural.

Na separação, o sujeito irrompe na cadeia significante e destaca-se o objeto a. Essa operação de separação permite que o sujeito encontre um espaço entre os significantes onde irá constituir seu desejo. No que seu desejo é desconhecido, o sujeito retorna então ao ponto inicial, que é o de sua falta como tal. Isso indica que alienação e separação não são estáticas e sim oscilações permanentes que se verificam nos sujeitos, como uma alternância sempre renovada. Esse movimento é necessário ao sujeito, pois o conduz em direção à assunção desejante e à escolha de uma modalidade de gozo própria pela qual poderá responsabilizar-se. Sem essas experiências de separação o sujeito fica retido como objeto do genitor numa eternização da infância com a consequente desresponsabilização de seus atos. Longe de ser tudo na vida de uma criança, o amor pode fazer muitos estragos quando se articula ao gozo e exclui a via do desejo.

Lacan (1973/1988, p. 202), com o termo separação, faz um jogo de palavras remetendo ao latim "se parare" que implica "engendrar-se", indicando o sentido pelo qual a separação promove algum acesso à liberdade, ainda que limitada. Pode-se concluir que o alienador, para reforçar a alienação, atua de forma a impedir a separação desde onde a criança, ao ler as faltas no discurso do Outro, poderia aceder a um desejo próprio. O procedimento do alienador implicará algo que é também da estrutura: ele próprio encarna o significante S1 que comanda toda a cadeia significante, mas distinto do objeto $a$, operador do real na estrutura. Mas, para que esse procedimento tenha eficácia na SAP, o alienador deve articular significante e gozo com o amor, que terá a função de encobrir o gozo da posse da criança como objeto.

Isso dá a característica do discurso do alienador, que aparece frequentemente como um discurso do amor e da virtude, dado que confunde os profissionais da área assentados na crença do amor e afeto à criança. Esse discurso moral e de busca do bem para a criança da qual o 
alienador se faz arauto, consciente ou inconscientemente, implica ocupar para a criança o lugar do saber acoplado à verdade. O adulto toma-se mestre absoluto, única referência de saber e do bem do sujeito, apresentando sua palavra como tendo valor de verdade. Isso passa uma convicção ao interlocutor, quando a psicanálise indica que a palavra partilha da mentira, uma vez que se trata da verdade do desejo, só apreendido através das entrelinhas da fala.

O genitor alienador, encarnando o Outro consistente e apresentando mandatos aliados ao amor, reforça a alienação configurando uma estratégia que impossibilita a separação que se torna invisível aos que acreditam nas ações feitas em nome do amor à criança, que se apresentam através de uma certeza, uma convicção e num discurso bem estruturado sobre o bem. Arguto em relação à natureza humana, Freud não se deixou enganar pelas teses rousseunianas da bondade inata do homem e da corrupção da sociedade, preferindo tomar partido da tese de Hobbes, que situa o homem como lobo do homem. Ou seja, não se deixou iludir pelo campo das boas intenções e do bem, pois sabia que a melhor forma de ocultar o gozo é o discurso do amor e do bem.

$\mathrm{Na}$ alienação constitutiva do sujeito, independentemente da presença do genitor e da forma de sua apresentação, seja ela exaltada ou denegrida, sua função é preservada no discurso do Outro. Pode-se aqui diferenciar quando existe uma alienação menor e passageira no pós-divórcio, e quando esta adquire as características de uma SAP, isto é, quando o outro genitor é eliminado no discurso do Outro, o que evidentemente traz implicações mais nefastas. Ainda que um genitor seja ausente devido afastamento ou morte, há preservação deste no discurso do desejo do outro genitor ou mesmo dos familiares, permitindo que a criança se localize como pertencendo a duas linhagens. Nesse sentido, a psicanálise permite evidenciar que, para além da questão de uma ruptura completa na relação alienador-criança, mais grave é a anulação da herança da linhagem simbólica de um lado. Permite-se, dessa forma, a partir da leitura da posição subjetiva dos genitores e da criança, 
realizar intervenções e trabalhar a prevenção de uma SAP antes mesmo que se localizem os fenômenos e sintomas no genitor alienador e na criança.

$\mathrm{Na}$ alienação promovida na SAP é engendrado um falseamento da matriz de origem ao ser negada a presença do desejo do Outro genitor na origem do filho e, por conseguinte, aniquilada sua função como modelo identificatório e fator determinante no destino do filho. O genitor alienador pretende assim ser a encarnação, não só o Outro da demanda, mas também o Outro do desejo, o Outro do gozo e o Outro do saber, tornando-se referência única e oferecendo significantes os quais a criança não pode recusar por se colocar como não amável ou ser punida. Essa exageração da alienação de causação do sujeito traz mais efeitos quanto menor a idade da criança, principalmente aquelas que ainda não passaram pela dissolução do Édipo em razão da consequente constituição de um supereu, separando-se do supereu arcaico que transforma todas as palavras em mandatos.

Em "Duas Notas Sobre a Criança" (1969/1998), Lacan aponta que a criança constrói seu sintoma respondendo ao sintoma do par parental, ou seja, seu sintoma corresponde ao que há de sintomático na estrutura familiar, definindo-se como verdade desse núcleo e, portanto, tendo implicação na subjetividade dos pais. Assim, a família, o par parental, é um recurso de que o sujeito dispõe para interpretar seu sintoma.

A criança neurótica busca completar o Outro com a família, ela vem no lugar do objeto a. "O sintoma pode representar a verdade do casal familiar. Esse é o caso mais complexo, mas também aquele mais aberto às nossas intervenções". (Lacan, 1998/1969, p.5). Isto porque, além de serem pai e mãe, há um casal: um homem e uma mulher, ou seja, há um encontro sexual entre dois sujeitos, trata-se, pois, de que lugar é dado, nesta relação, à falta. Isto implica que um homem e uma mulher se situam em relação ao objeto a causa do desejo pois o homem pode escrever uma mulher como sua falta, implicando que ele está castrado; e a mulher inscreve o Nome-do-Pai (pai simbólico) implicando que ela está castrada. Portanto os dois sujeitos têm que estar em relação à castração para que o filho possa funcionar como sintoma do casal parental. Se essa falta se 
inscreve, a criança é neurótica, é capaz de ter sintomas. Mas se o Nome-dePai não se inscreve e o Desejo da Mãe não é barrado, se este Outro do capricho não é barrado, a criança irá se incluir na estrutura da psicose, pois fica capturada na estrutura fantasmática da mãe. Ela se torna um objeto da fantasia materna: a criança se torna um objeto condensador de gozo. Ou seja, é um objeto que não está simbolizado, que não entrou nas equações simbólicas por uma falha na simbolização. Esta falha, do lado da mãe, é subjetivada pela criança como foraclusão do Nome-do-Pai. Não houve uma transmissão do Nome-do-Pai.

$\mathrm{Na}$ SAP, a alienação engendrada leva a criança a responder ao sintomático do casal com pouca distância do sintoma dos pais, o que implica um maior sofrimento e alienação do desejo. Nesse caso, os pais como casal manifestam que a causação do desejo se faz ineficaz nesse momento e a criança se vê obstaculizada em sua experiência de separação do Outro, ficando atrelada ao gozo de um dos genitores, ainda que a fantasia tenha sido partilhada por ambos.

Os efeitos deletérios advêm do fato de a criança, alienada na demanda de um dos genitores, não poder ler os significantes que este the oferece nem ler o desejo do Outro. Quanto maior a eficiência do alienador em encobrir a programação com um discurso de amor ao filho, mais dificilmente a criança poderá fazer essa leitura do desejo desse Outro, maior será a alienação do sujeito e seu aprisionamento num gozo antinômico ao desejo.

O fato de o sintoma da criança ser uma resposta ao sintoma do casal parental ou, como preconiza a Psicologia, da dinâmica familiar, pode levar à conclusão de que a rejeição da criança é uma resposta ao sintoma do casal, portanto de igual responsabilidade do par parental. Essa lógica simplista pode levar a um diagnóstico pobre e a intervenções que aprofundem o estado de alienação. O psiquismo não se reduz à ordem do sintomático, caso fosse assim, a criança seria pura resposta reflexa do inconsciente dos pais. Há uma tessitura complexa do gozo, do desejo e do significante tanto da criança como em cada genitor. A rejeição na SAP não pode ser tomada como equivalente ao sintoma. 
A rejeição neste estudo foi apontada para além do sintoma, um tipo de transferência entre criança e genitor alienador. Na área da Psicologia, os profissionais tendem a dizer que a recusa da criança é responsiva a uma "dinâmica familiar" de corresponsabilidade tanto do genitor alienado quanto do alienador; para Gardner, a recusa da criança em formato de SAP (não qualquer tipo de recusa) é responsiva a uma programação sistemática do alienador.

Num caso de SAP grave em ação de obrigação de fazer de visitas, pôde-se observar o entrecruzamento do sintoma do par parental e da resposta de rejeição na SAP por parte das filhas. Duas meninas préadolescentes recusavam o contato com o pai, difamando-o veementemente. A psicóloga perita concluiu que a atitude das filhas era simplesmente devido às brigas entre pai e mãe. Ainda afirmou que o pai demandava do judiciário uma solução mágica ao seu problema sem empreender esforços em mudanças pessoais. Segundo a profissional, nada poderia ser feito na esfera judicial para resgatar a relação rompida havia dois anos a não ser que se restabelecesse um diálogo cordato entre os genitores.

O caso desta família era semelhante ao descrito por Gardner em estágios graves de SAP em que se encontra o quadro de "folie à deux". Após o divórcio, a mãe, policial aposentada, passou a chorar quando o pai chegava para buscar as filhas. Limpava sua arma enquanto se lamentava sobre não querer mais viver, sobre o marido ter acabado com sua vida. As filhas passaram a evitar as visitas ao pai para poupar a mãe do sofrimento. Esta, após o divórcio, passou a uma religiosidade extrema, levando as meninas quase todos os dias aos cultos. O pai tentou uma primeira aproximação via igreja, pois ainda tentava vê-las mesmo após tanto tempo distante. Ficou no fundo da igreja durante o culto. Quando as filhas o viram, gritaram: Satã! Satã! Você não pode entrar na casa de Deus, nunca foi religioso. Fingido! Farsante! Nunca mais será perdoado. Em seguida saíram correndo da igreja. O pai referiu-se às filhas dizendo: Eram pessoas estranhas que nunca havia visto na vida, eram outras pessoas. Nunca fomos religiosos. Eu não estava entendendo nada. 
Neste caso foi possível observar a resposta sintomática das filhas ao sintoma do par parental. A mãe, uma mulher dez anos mais velha do que o pai, sentia muito ciúme do marido, que, sedutor e galanteador, trocava confidências com as filhas, eram suas "namoradinhas". A mãe tinha muito ciúme inclusive do pai com as filhas. Segundo ele, ela vivia interrompendo os momentos entre pai e filhas sendo áspera, gritando e dando ordens. 0 gatilho que iniciou a SAP após a separação, a frase: Filhas, ele nos traiu com outra mulher, passou a ser repetido em coro pelas três. As meninas passaram a sentir ódio e rejeitar o pai.

A recusa das meninas ao pai veio incidir sobre o sintoma do casal parental As "Namoradinhas do pai", representavam rivais para a mãe. Após a separação, foram convocadas a uma identificação forçada à mãe - ele nos traiu -, revirando em ódio o amor edípico em relação ao pai. Esses elementos deixaram de ser resgatados ou aprofundados na perícia. 0 sintoma que o casal produziu em sua união não responde pela alienação na SAP, embora sirva de pano de fundo, o que é usado pelo alienador. A rivalidade, ciúme, sentimento de traição fazem parte do Édipo, mas nesse caso não justificam a recusa neste caso.

O genitor alienado não pode ser apontado como vítima segundo os preceitos da psicanálise e conforme sugere Gardner. No entanto, há que se marcar a diferença no acento de responsabilidades dos genitores quando a SAP representar uma prática insidiosa, direta na criança, para que se possam estabelecer intervenções que levem em conta não só a participação do casal frente ao sintoma dos filhos, mas a necessária responsabilização do genitor alienador por apresentar um gozo desenfreado e impedir o genitor alienado de frear e velar tal gozo, cuja incidência causa maiores efeitos na criança.

A separação matrimonial, mesmo quando pode representar para um genitor um desastre subjetivo, não pode ser utilizada para a exclusão do lugar de um dos pais e da linhagem da filiação simbólica. Se para se constituir como sujeito, a criança necessita da mãe na sua função de desejo, necessita também do pai, um personagem que pode vir a ordenar uma vida 
e possibilitar que algo demarque o gozo, algo que dê o suporte do sentido. Se o gozo não está regulado pela castração, o vínculo com os outros e a realidade não poderão estar suportados pelo fantasma, e o sujeito não teria nada para se proteger do real, estaria numa condição de devastação.

A família é o lugar do encontro com o gozo e o convite à sua renúncia. Mas, para que isso ocorra, os agentes que sustentam as funções têm de possibilitar essa formulação: inscrição do gozo e necessária perda, ou seja, devem permitir que a família seja o lugar desse bem precioso e o lugar vazio de sua perda, pois, se o gozo não existisse, o universo seria em vão. É exatamente o oposto do que ocorre na SAP, o genitor alienador não consente em condescender o gozo ao desejo e aloca o filho como objeto de posse para que recupere o gozo perdido, convocando o filho à partilha desse mesmo gozo.

O sintoma do filho tem sempre algo do familiar, mas isso não significa que o gozo dos filhos seja o mesmo que o dos pais. Como o sujeito sai do Édipo repetindo no par a marca familiar, a configuração familiar situada na infância e adolescência é de máxima importância, porque será a partir daí que os sujeitos ensaiam as novas formas de ratificação do impossível da relação sexual.

A castração como operação fundante do real na estrutura - a falta central inaugura a passagem o espaço para a passagem do gozo ao desejo, via aberta na infância que deve perdurar. A história do sujeito nada mais é do que a história dos modos de falta do objeto impossível, resultados da experiência de encontro com o traumático sexual. Isto é, a impossibilidade de uma cópula entre o gozo do lado feminino e do lado masculino, pois cada parceiro na relação tem como parceiro o gozo, o gozo de um não sendo complemento do outro. Mas, se a família se sustentar sob o regime do Um de exceção - o pai de gozo (Lacan, O avesso da psicanálise, 1992/19691970), isto é, sob o domínio do gozo de um dos genitores que aloca a criança como propriedade e como objeto de gozo, excluindo a outra parte do contrato simbólico conjugal, ela impedirá que a criança se encontre com 
essa verdade e passe do trauma à fantasia que lhe permitirá afrouxar seu sintoma em relação ao sintomático do genitor.

Uma coisa é o sintoma de um filho ser a resposta ao recalcado familiar, ao segredo familiar, ao fantasmático familiar, e outra coisa é o sintoma decorrer da captura da criança como objeto de gozo de um dos genitores. Ou seja, um pai que falta como homem que goza de uma mulher abandona a criança ao gozo do Outro. A mãe que não concede ser, como mulher, causa do desejo de um homem, goza dos filhos ao invés de se

ocupar deles. É a conjugalidade que funda a parentalidade e, se recusada a condição desejante em um dos pais, a criança será colocada como objeto de gozo.

É nesse ponto que a SAP vem como instrumento de diagnóstico diferencial entre a alienação constitutiva do sujeito fundamental na estrutura edípica e uma alienação produzida por um genitor que usa a criança como objeto de gozo para objetivar a exclusão do outro genitor, negando sua condição desejante e de uma parte da linhagem familiar.

Na SAP, uma das figuras parentais é apresentada como perigosa, prejudicial, incapaz, negligente. Porém não se resume a uma alienação em relação a uma das figuras parentais. Suas consequências são mais amplas e deletérias do que a exclusão concreta de um genitor da vida cotidiana dos filhos. Isso porque, para ter sucesso em instalar a SAP, é preciso gerar um estado mais aprofundado da alienação que incide na alienação constitutiva regra para todo entendimento da patologia em psicanálise e que precisa ser diferenciado.

\subsubsection{A SAP como um tipo de transferência}

No subcapítulo anterior, a alienação-separação, aparece como conceito-chave para o entendimento da síndrome de alienação parental. No entanto esse conceito pouco ajuda a compreender a SAP, apenas explica a gênese da alienação, isto é, que a eficácia da SAP decorre do fato de ela recuperar ou sobrepor-se a um processo normal, a alienação 
fundamental e constitutiva, mas com exageração - regra final para toda compreensão psicanalítica do patológico. Isto é, a relação da criança com as figuras cuidadoras que encarnam o lugar do Outro pressupõe a operação de alienação. Trata-se, portanto, de analisar qual a especificidade e a exponência da alienação na SAP e possíveis consequências.

É preciso, portanto, precisar clinicamente a ocorrência da síndrome em termos estruturais. Dessa forma, será trazido um recorte do conceito de transferência de Freud a Lacan para então se articular a ideia de que a SAP pode ser formalizada como uma modalidade de transferência que o alienador estabelece com a criança ao instaurar um discurso denegritório sobre o genitor alienado para evitar e até impedir que ele ocupe o lugar de Outro para a criança.

Para essa análise, é preciso decompor os elementos que fazem parte da estrutura da transferência e que participam da formação da SAP: identificação, idealização, fantasia e sugestão. A SAP não se resume a uma forma de identificação, idealização, sugestão ou fantasia e sim numa conjuntura específica que pressupõe a reunião desses elementos ligados a uma tipo de demanda específica - demanda imperativa do genitor cuidador que encarna o Outro da criança. Por isso, posteriormente, identificar-se-á a posição subjetiva da criança diante do discurso do alienador para explicitação da tese em questão.

Na SAP há uma maciça demanda ligada ao amor, pois a criança se sente amada enquanto responde aos significantes enunciados no discurso do genitor alienador, o que Gardner indica como programação sistemática. O que é próprio da constituição do sujeito, a alienação aos significantes da demanda, é reforçado gerando um efeito patológico que elimina o outro genitor da função de representância do Outro.

Isso se dá porque o genitor alienador encarna o Outro da demanda absoluta, ou seja, reduz a demanda à necessidade, torcendo o registro para o lado do que a criança tem que responder para sobreviver. Assim, o genitor alienador impede que se instaure um mais-além da demanda, 
pois, a partir das falhas no discurso parental, a criança poderia se perguntar sobre o que sua fala quer dizer, ou seja, "O que o Outro quer de mim?" e elaborar uma resposta própria e diferente do arrolhamento que ela é convocada a fazer ao constituir-se como sintoma do Outro.

É a essas demandas maciças, constantes e ininterruptas que a criança tem de responder. São significantes que, por não serem articulados ao campo do desejo, assumem a forma de mandatos superegoicos. Pode-se concluir que esses significantes isolados, por não se articularem à rede de significantes, funcionam como vontade de gozo e situam a criança como objeto de gozo.

Aqui, o papel do amor torna-se crucial, pois ele encobre toda a operação de reforçamento da nova alienação, impedindo a vivência da separação diante da qual a criança, para ser amada, se submete, tomando o discurso do Outro sem nenhuma leitura ou distanciamento. O efeito completo disso é visto na SAP quando a criança passa a recusar tudo que vem do genitor alienado - palavras, gestos, presentes, companhias, família, entre outras ofertas, mesmo na ausência do alienador.

O lugar evocado, desde que há fala, esse lugar terceiro que existe nas relações com o outro, é o lugar do Outro afetado por uma falta e, por isso mesmo, coloca o sujeito numa posição evanescente, aparecendo e desaparecendo entre um e outro significante, no movimento metonímico do desejo. Na situação de programação, o Outro torna-se consistente, presença absoluta que propõe para a criança a certeza de seu ser e de seu desejo sem passar pela falta, pela alteridade.

O Édipo como mito é uma versão imaginária dos acontecimentos cuja repetição revela uma invariante - uma estrutura, que situa as perguntas fundamentais da existência de um sujeito: origem da história individual do sujeito, origem da sexualidade e a origem da diferença sexual. O Édipo implica uma estrutura em que se dá uma operação que historiciza o sujeito e lhe outorga uma identidade e destino sexual.

Essa estrutura, em que se localizam os desejos e funções, Freud situou através do conceito de inconsciente e do Complexo de Édipo, onde 
se localiza o sujeito. Lacan renomeou como Outro, alteridade radical, que se faz presente para o sujeito pela fala e pela linguagem e integra 0 simbólico, que é da ordem da cultura e onde se localiza um desejo anterior ao sujeito, desde onde ele poderá advir. Somente poderá dizê-lo, se tiver operado estas duas fases: a renúncia a este primeiro objeto (que passa a ser o fundador de seu desejo e que estará inscrito no seu inconsciente); e a identificação com o pai, que lhe fornecerá um modelo para a execução deste quantum libidinal, porém em regime exogâmico.

O Édipo concebido como estrutura é um lugar - vazio, pois a castração indica a perda do objeto mítico: uma função - da mãe, de instauração de seu desejo; do pai, de fornecer emblemas como referentes para o desejo - e um código - lugar da bateria significante, do saber inconsciente, daquilo que está para além dos sujeitos falantes, envolvidos num diálogo. Enfim, o Édipo é um lugar onde o sujeito se determina a partir das identificações com outros desejantes, que o representam (por meio de estruturas de parentesco), à um campo de experiências estruturado por um sistema de linguagem, de regras normas e posições.

Os pais como Outro, alteridade radical, devem encarnar funções necessárias à constituição do sujeito, mas também ocupam posições que se determinam desde esse lugar, permitindo enlaçar o amor, o desejo e o gozo. A função do Outro na estrutura, no nível imaginário está sustentada pelo semelhante (outro). O outro como parceiro do eu na relação intersubjetiva, que se caracteriza por ser uma relação especular e narcísica. Mas a função que nos interessa aqui é a que se dá numa relação simbólica, em que os pais são tomados como alteridade numa dimensão terceira, como representação do saber do Outro, ou seja, a que permite acesso ao saber e ao desejo.

Essa dependência dos pais, o semelhante enquanto encarna o Outro, concebido pela psicanálise como lugar do código, é um assujeitamento à palavra, pois o desejo depende da fala e da linguagem. Não há pensamento sem palavras e esta implica a dimensão do terceiro. Assim a transferência se faz obrigatória e universal, pois "há transferência 
cada vez que um homem se dirige a outro, falando de maneira autêntica e plena, aqui se trata de transferência simbólica". (Lacan, Escritos, 1992, p. 440)

Os genitores como representantes do lugar do Outro, além da função desejante e de transmissão do gozo, veiculam ideais com os quais a criança se identifica. O discurso parental, discurso do Outro, indica e revela o lugar da criança antes de ser falante. Tomado inicialmente como projeção narcísica de um ideal de máxima perfeição e completude (eu ideal) a partir da ferida narcísica dos pais, esse discurso apresenta significantes que representam um ideal relativizado pela castração (Ideal de Eu), pois admite ser impossível uma sutura entre a criança e essa aspiração. Essas insígnias oferecidas pelo Outro fornecerão o ponto desde onde a criança, ao se identificar, se verá como amável pelo Outro.

Vê-se aí o poder da palavra, pois essa operação de identificação se dá a partir do discurso do Outro, do outro - o genitor representante da Lei do desejo, da oferta de significantes para o sujeito identificar-se e ser amado. Esse outro passa a configurar-se então como Outro do saber, lugar do inconsciente como saber insabido, desde onde a criança se dirigirá para poder acessar seu desejo.

Para desenvolver e articular o conceito de transferência à SAP se faz necessário retomá-la desde sua descoberta. No texto de 1895 "A psicoterapia da histeria", Freud situou a transferência (Übertragung) como uma falsa ligação ao indicar o deslocamento de significantes para a pessoa do médico ${ }^{12}$. Ele redefiniu que o que se colocava como falso era a dimensão do amor, pois a transferência se manifesta toda vez que um sujeito endereça sua palavra a qualquer outro ser humano, não sendo ele apenas um médico ou psicanalista. No texto de 1905, ele refefine o conceito:

12 Diversas vezes o profissional "médico" será referido nesse trabalho no lugar do psicanalista pois na época em que a transferência foi descoberta por Freud não existia a figura do analista. A relação transferencial médico-paciente foi posteriormente transportada à todas as relações que o sujeito estabelece em sua vida. 
O que são transferências? São reedições, reproduções das moções e fantasias que, durante o avanço da análise, soem despertar-se e tornar-se conscientes, mas com a característica (própria do gênero) de substituir uma pessoa anterior pela pessoa do médico. Dito de outra maneira: toda uma série de experiências psíquicas prévia é revivida, não como algo passado, mas como um vínculo atual com a pessoa do médico. (1905b/1996, p.111)

No texto "Dinâmica da transferência" (1912/1996), a transferência aparece como o mote central da análise dos neuróticos funcionando como motor da cura. Para Freud, no tratamento analítico, a transferência diz respeito à relação do analisante com seu analista enquanto uma atualização ou repetição da maneira como este estabelece as relações com seus semelhantes. Neste mesmo texto, aponta o fenômeno como sendo gerado a partir de processos psíquicos fazendo parte da vida cotidiana dos seres humanos. A transferência, portanto, segundo Freud, não é específica do campo da psicanálise: "O tratamento psicanalítico não cria a transferência, mas simplesmente a revela" (1996/1905 [1901], p.112).

Em "A história do movimento psicanalítico", se refere "à natureza universal deste fenômeno" (1914a/1996, p. 22). Freud justifica sua existência a partir de uma disposição da neurose: "Essas características da transferência, portanto, não devem ser atribuídas à psicanálise, mas sim à própria neurose." (1912/1996, p.113).

Portanto, na visão freudiana, a transferência existe em todas as esferas das relações humanas, seja nas relações pessoais, no social, dentro das instituições e na situação analítica. "Não é fato que a transferência surja com maior intensidade e ausência de coibição durante a psicanálise que fora dela" (1912/1996, p.113). Ela decorre das condições da neurose, de capacidade do paciente de transferir sentimentos afetuosos conscientes tanto quanto de sentimentos inconscientes e a sugestão como a influência "de uma pessoa por meio de fenômenos transferênciais possíveis no sujeito" (1912/1996, p. 140).

Esta segunda versão de transferência - libidinal, por dizer respeito à relação do sujeito com o outro, nos permite apresentar que uma 
transferência aparece de forma particular entre genitor alienador e criança alienada.

No texto de 1912, Freud articula a transferência ao amor. O fenômeno aparece como conceito tomado como deslocamento e através de uma explicação genética baseada na constituição regular da vida amorosa do ser humano. A partir de disposições inatas e experiências infantis se institui precocemente uma especificidade para as condições de amor que se estabelecerá. Ou seja, a transferência é uma estrutura que se repete de modo regular durante toda a vida - um clichê, e estabelece que parte das moções determinantes da vida amorosa permaneça inconsciente. Quando a necessidade de amor é insatisfeita, estas moções libidinais buscarão novos objetos.

Freud além de situar a transferência como fenômeno universal decorrente da estruturação psíquica, destaca que a sugestão como fenômeno se subordina a ela, para Lacan o fenômeno de sugestão se subordina à transferência como razão.

Assim a transferência associa-se ao conceito de neurose, e implica o modelo de relação do neurótico com o outro, pré-estabelecido desde a infância, antes mesmo que se dê o vínculo, o que no texto "Observações sobre o amor transferencial" (1915a/1996), se refere à transferência como "precondições para amar" (p.184). Aquilo que não é satisfeito anteriormente, se transporta, se desloca retornando posteriormente na forma de transferência: "Se a necessidade que alguém tem de amar não é inteiramente satisfeita pela realidade, ele está fadado a aproximar-se de cada nova pessoa que encontra com ideias libidinais antecipadas" (1912/1996, p.112). Dessa forma, a forma de amar do neurótico, de estabelecer relações com objetos amorosos, desconsidera parcialmente as características da realidade ou do objeto. Se "compõe inteiramente de repetições a cópias de relações anteriores, inclusive infantis" (1915a/1996, p.185). 
existe estado deste tipo que não reproduza protótipos infantis. É precisamente desta determinação infantil que ele recebe seu caráter compulsivo, beirando como o faz, o patológico. O amor transferencial possui talvez um grau menor de liberdade do que o amor que aparece na vida comum e é claramente menos adaptável e capaz de modificações. (Freud, 1915a/1996, p.185).

Na SAP, o manejo transferencial pelo genitor ao colocar a exigência de um amor desmesurado na relação com o filho, o deixa numa condição de menor liberdade, beirando amor patológico, um amor alienado, como se refere Freud. Ele faz uma colagem da alienação nova em torno da fixação do protótipo dos primeiros objetos eleitos pela criança que marcarão um porvir. Nesse sentido que a interferência do judiciário pode ser de grande importância, vem a limitar o uso do filho como objeto de posse, pois este deixa pouco espaço para um amor genuíno, que reconheça a alteridade e as diferenças.

As escolhas objetais que a criança fará em sua vida têm assim íntima relação com as raízes do amor infantil, pois se transfere o modelo do amor nas relações infantis para os objetos eleitos na vida ulterior. Por isso, a transferência de afetos positivos ou negativos, amorosa ou hostil ao médico, embora tomadas como motor da cura ou resistência, não se aplicam diretamente à pessoa do médico, pois deriva de outro lugar e repete algo que aconteceu anteriormente. Mas, na medida que a transferência leva um sinal 'mais', ela reveste o médico de autoridade e suas comunicações se transformam em crença.

$\mathrm{Na}$ ausência de tal transferência, ou se a transferência for negativa, o paciente não dá ouvidos ao médico e a seus argumentos. Aqui, a crença repete a própria história de seu desenvolvimento; é um derivado do amor e, no princípio, não precisa de argumentos. Apenas mais tarde ele permite suficiente espaço para submetê-los a exame, desde que os argumentos sejam apresentados por quem ele ama. (Freud, 1915[1916]/ 1996, p. 446)

Freud conclui que se deve atribuir a toda pessoa normal uma capacidade de dirigir catexias libidinais às pessoas e a tendência à transferência nos neuróticos como um aumento extraordinário dessa 
característica universal, traço humano tão difundido, e destacado por Bernheim que a caracterizou como sugestionabilidade. Freud trata a sugestão como um fenômeno que depende da arquitetura em que se suporta a transferência que enlaça sexualidade, desejo e inconsciente.

\subsubsection{Articulação da sugestão na SAP}

Nesse sentido, a tese de que a SAP é um tipo de transferência entre genitor alienador e a criança, nos permite articular a sugestão ao processo da SAP, por ser elemento formativo da transferência. Apesar de não pode ser apontada como componente exclusivo na SAP que permita explicar sua ocorrência, a sugestão aparece de forma maciça na instalação da alienação de Gardner.

Freud discute a sugestão enquanto técnica terapêutica apesar de têla abandonado posteriormente por concluir que seu manejo era deletério aos pacientes. No texto "Psicologia de grupo e análise do ego" (1921/1996) aponta os efeitos da sugestão no campo das relações para além da situação analítica, o que permitirá transpor a sugestão para a relação entre genitor programador e a criança.

O termo sugestão surge ligado ao tratamento de doenças orgânicas e não-orgânicas onde se constatava a ação eficaz da hipnose através da possibilidade de influência benéfica do médico sobre o doente. No entanto, o poder hipnótico ou sugestivo do médico para com seu paciente, explica Freud, está além da situação analítica, pois a sugestão é "um fenômeno irredutível e primitivo, um fato fundamental na vida do homem" (1921/1996, p.100). No entanto, o poder de influência do alienador na criança não pode ser entendido apenas a partir da relação de dependência entre os filhos e seus pais por incluir um grande grau de sugestão. A relação filial permite explicar a força aumentada desta influência, mas é o manejo da sugestão que aparece como elemento central para o entendimento da instalação da SAP. 
Em "Tratamento psíquico (ou anímico)" (1905b/1996), Freud dispensa a sugestão no tratamento dos doentes por sua eficácia parcial e uso do poder autoritário. Aponta seus efeitos limitados, frágeis e deletérios no psiquismo dos pacientes. Por ser frágil, isto é, pelo fato da sugestão poder ser desfeita de uma maneira relativamente fácil, a SAP não pode ser entendida apenas a partir da mesma necessitando de outros elementos que serão posteriormente articulados à transferência na SAP. No entanto, esta afirmação de Freud permite em parte entender a relação de poder exacerbada que se estabelece entre a criança e o alienador, a facilidade com que as sugestões de alienação se desmontam imediatamente em algumas situações, por exemplo, após algumas decisões judiciais e também permite entender o efeito iatrogênico desta na criança.

Aponta Freud que o tratamento atua através do poder das palavras. Este poder curativo é utilizado desde a antiguidade por várias práticas como magia, bruxaria e medicina:

É que as palavras são o mediador mais importante da influência que um homem pretende exercer sobre o outro, as palavras são um bom meio de provocar modificações anímicas naquele a quem são dirigidas, e por isso já não soa enigmático afirmar que a magia das palavras pode eliminar os sintomas patológicos, sobretudo aqueles que baseiam justamente nos estados psíquicos (1905b/1996, p. 279).

Da mesma forma que para Freud o médico utiliza o poder das palavras para sugestionar a cura do doente, na SAP o poder das palavras é dirigido com intuito de fazer a criança rejeitar, hostilizar, desmoralizar o outro genitor.

Lacan marca a diferença entre palavra e significante. Indica que não é a palavra, mas o significante que apresenta esse poder. Isso permite entender porque Gardner afirma que não são apenas as falas depreciativas do alienador sobre o alienado que induzem a SAP, mas um olhar de reprovação, um abraço desesperado ao chegar das visitas, uma risada de deboche quando o outro genitor liga, possuem efeitos tão fortes e mais sutis até mesmo do que uma fala desmoralizadora. Tais gestos, enquanto significantes enunciados são capturados como mensagem pela 
criança dando significado de um desprezo, de uma crítica, do genitor representar uma ameaça, um perigo. Este aspecto será posteriormente trabalhado mais detidamente.

Para Freud, o poder curativo da palavra advém do poder que se atribui ao agente da cura e da confiança que se estabelece. Essa transferência de poder advém tanto de uma predisposição do sujeito como do agente da cura, pois este deve fazer a pessoa ter fé na cura, ou em qualquer outra crença para que se atinja o objetivo. Freud precisa o estado do hipnotizado ante o hipnotizador como um obediente crédulo comparando com a amamentação na relação mãe-bebê, onde a criança se torna completamente dócil frente à mãe. Ainda no texto de 1905:

Enquanto o hipnotizado comporta-se perante o mundo externo como se estivesse adormecido, com todos seus sentidos desviados dele, está desperto para a pessoa que o hipnotizou: vê e ouve apenas a ela, compreende e the dá resposta. (1905b/1996, p.282).

Pode-se estabelecer uma breve analogia com a SAP. Se no tratamento, a sugestão liga-se à cura, na SAP a sugestão liga-se à exclusão, desmoralização ou animosidade em relação ao genitor alienado. Trata-se de trazer para o mesmo plano a relação entre criança alienada genitor alienador e a relação hipnotizado-hipnotizador.

A característica mais importante na hipnose está na atitude do hipnotizado perante $\mathrm{o}$ hipnotizador marcada pela obediência e credulidade, aumentando o poder do hipnotizador cuja palavra torna-se magia. Sobre a credulidade demonstrada pelo hipnotizado perante 0 hipnotizador:

...só é encontrada nos filhos perante os pais amados, e que uma adaptação semelhante da própria vida anímica à de outra pessoa, com submissão análoga, encontra paralelo único, mas integral, em algumas relações amorosas plenas de dedicação. A combinação de estima exclusiva com obediência crédula costuma estar entre as marcas distintivas do amor. (Freud, 1905b/1996, p. 283).

Freud transporta o estado hipnótico para outras situações além da relação médico-paciente, por exemplo, na relação entre pais e filhos e nos estados amorosos: 
A fala do hipnotizador, que exibe os efeitos mágicos anteriormente descritos, é chamada de sugestão, e acostumamo-nos a empregar esse termo também quando há, em princípio, meramente a intenção de provocar um efeito semelhante. (1905b/1996, p.283)

Diante desse poder, o sujeito crédulo pode ser forçado a ver o que não está ali, mas pode também ser proibido de ver algo que está presente e que pretende impor-se a seus sentidos e até ser sugerida uma ação que ao sujeito espertar justificará ter feito por um impulso obscuro que não pôde resistir ou inventará algum pretexto óbvio e precário, sem se lembrar da verdadeira razão - a sugestão que lhe foi feita.

Pode-se associar esse efeito da sugestão ao que Gardner afirma na SAP de que a percepção da criança sobre o genitor alvo é negada e deformada constantemente pelo programador. A brusca depreciação por um genitor que sempre fora amado torna-se possível, pois a criança vê o que não está ali, e o que vê é a sugestão do alienador: uma simples tarefa do lar vira algo do tipo ele me escraviza, me bate, me maltrata. Gardner refere que a criança alienada diz e sente coisas a respeito do genitor alienado mas não sabe o porque, apenas as repete, as sente e não sabe justificar nem explicar. Afirma também que a criança mimetiza a percepção exagerada, projetiva, fantasiosa ou delirante que o genitor alienador possui de seu ex-cônjuge. Mas, o que explica esse poder do alienador na criança se os filhos também possuem laços com o outro genitor?

Diferentemente de atribuir o alinhamento a pequenas dificuldades que possam haver na parentalidade do alienado, o forte alinhamento pode encontrar suas raízes na sugestão do alienador e em uma tendência natural dos sujeitos, especialmente quando há pouca separação do Outro, o que é maior na criança. Nesse sentido, Freud articula os efeitos da sugestão às características naturais do neurótico. Em "O método psicanalítico de Freud" (1904[1903]/1996) aponta que a eficácia da hipnose repousa no conteúdo do que é veiculado pela sugestão. Em "Sobre a psicoterapia", a hipnotizabilidade "reside no livre-arbítrio do 
paciente" (Freud, 1904-1903/1996, p. 237) e o resultado da hipnose depende da disposição psíquica do hipnotizado.

O que caracteriza o alto grau de sugestionabilidade presente SAP? Cabe uma observação neste ponto, uma vez que a relação da criança com seus pais não equivale à mesma relação médico-paciente. Como Freud afirma, há uma especial submissão na relação entre pais e filhos, o que os tornam especialmente sugestionáveis por estas figuras.

As incessantes sugestões feitas na SAP, apontadas por Gardner como programação sistemática, a busca obstinada por preencher os "espaços de tempo" da criança com programações, marca particular da SAP, permitem entender o sucesso da alienação.

Antes que a criança atinja um grau severo de alienação no qual se observa o rompimento total da relação com o genitor alienado, pode-se mais facilmente reverter a SAP. As frequentes sugestões, repetições e atos do alienador contornam a fragilidade da técnica da sugestão fornecendo a chave para o entendimento da sustentação da SAP através da persistência e repetição presentes na sugestão ligada a SAP. Freud, no texto de 1921, retoma a teoria de Berheim que afirma que para produzir o efeito em um grupo não necessita ter ordem lógica em seus argumentos mas "deve exagerar e repetir a mesma coisa diversas vezes" (p.89), e completa que "as idéias mais contraditórias podem existir lado a lado e tolerar-se mutuamente, sem que nenhum conflito surja da contradição lógica entre elas." (p.90), dessa forma a função de verificação da realidade cai para segundo plano.

Freud diferencia sugestão e transferência. Ressalta que a sugestão implica uma modificação superficial do atual do problema e por isso desmorona facilmente. Razão esta pela qual se entende que a SAP não pode ser entendida apenas a partir do manejo da sugestão e da relação hipnótica.

No texto "Sobre a psicoterapia" (1905[1904]/1996) Freud opõe a técnica sugestiva à técnica analítica. Enquanto a sugestão opera per via di porre "não se importa com a origem, força e sentido dos sintomas 
patológicos, mas antes deposita algo - a sugestão"; a transferência na análise opera per via de levare, isto visa "tirar, trazer algo para fora e para este fim preocupa-se com a gênese dos sintomas patológicos" (1905[1904]/1996, p.247).

Os efeitos do manejo da sugestão trazidos por Freud permitem no mesmo sentido ser articulados aos efeitos da SAP: o efeito iatrogênico será maior quanto mais fortes o recalque e a alienação no campo da subjetividade. É o que Freud apresenta na conferência 28 "A terapia analítica" (1917[1916b]/1996). Sobre a diferença entre a terapia sugestiva e a terapia psicanalítica:

O tratamento hipnótico procura encobrir e dissimular algo existente na vida mental; o tratamento analítico visa expor e eliminar algo. O primeiro age como cosmético, o segundo como cirurgia. O primeiro utiliza-se da sugestão, a fim de proibir os sintomas: fortalece as repressões, mas fora isso deixa inalterados todos os processos que levaram à formação dos sintomas. (1917[1917]/1996, p. 451).

Em "Psicologia de grupo e análise do ego" (1921/1996), Freud amplia seus estudos sobre a sugestão para além da situação analítica ao propor que os laços libidinais permitem explicar a natureza e condição do poder de influência nas relações em geral.

Freud se refere a dois tipos de laços libidinais - a identificação a um objeto e a eleição de um objeto do amor. Na identificação, reconhece-se no objeto eleito e deseja ser como este objeto. Há um esforço por moldar o próprio ego segundo aspectos daquele que foi tomado como modelo passando a ocupar lugar de ideal.

Há um segundo tipo de laço, no qual a vinculação libidinal dá-se diretamente com o objeto. Pode se traduzida por querer ter o objeto que ao receber o investimento da libido é introjetado no ego. Resumindo estas duas formas de ligação libidinal, ora o laço se liga ao objeto do ego, ora diretamente ao sujeito.

Se o poder de sugestão é explicado pela ligação dos laços libidinais, os pais sendo as primeiras figuras tomadas como objeto de amor e de identificação da criança, se revestem de especial poder de sugestão. 
Desde as relações de parentalidade, permite-se entender a capacidade de laços que a criança desenvolve posteriormente. Tal observação permite entender o poder do genitor programador em alienar a criança contra o outro genitor que não conviva tão diariamente com a criança. A relação de sugestão mostra-se aumentada em relação ao genitor de quem a criança tem maior dependência, por isso Gardner refere ser uma típica patologia instalada pelo guardião.

Será retomada a fórmula da hipnose freudiana para transpor a relação hipnótica que se estabelece entre criança alienada e programador na SAP, isso, pois Freud ampliou a relação hipnótica para além da relação entre hipnotizado e hipnotizador. A fórmula libidinal que permite explicar o laço na relação hipnótica reside no fato de que, o objeto do amor escolhido (hipnotizador) é alocado no lugar do ideal de ego do hipnotizado produzindo uma fascinação. O ego se assujeita e se devota ao objeto eleito, pois sua iniciativa fica debilitada e se instala uma relação de desamparo e poder em relação a alguém com poderes superiores (1921/1996, p.122-125). A idealização do objeto produz um falseamento do julgamento a respeito deste e perda de crítica.

Neste tipo de ligação fica evidente alto grau de sugestionabilidade e a relação de poder que podem ser transportados ao tipo de laço que a criança estabelece com o alienador. Ele constitui o único objeto e a criança não presta atenção em mais ninguém a não ser ele. Quando o genitor alienado tenta desfazer uma versão distorcida dos fatos é fortemente rechaçado pela criança. Gardner exemplifica o caso de uma criança que repetia as frases de sua mãe: seu pai não pagava pensão. Quando o pai mostrou os pagamentos efetuados no banco, a criança afirmou que ele havia fabricado a prova apenas para dizer que sua mãe mentia. A criança pode ver apenas o que é afirmado - que o pai não paga pensão.

Freud amplia a explanação da relação dual hipnótica para o funcionamento em grupo. Na SAP, é possível tanto ressaltar o estado hipnótico produzido a partir da ligação entre criança alienada e alienador 
quanto o aspecto de funcionamento de grupo e seu líder quando existem irmãos alienados exercendo influências uns sobre os outros.)

Segundo Freud (1921/1996) no grupo, o indivíduo abandona sua distintividade para ser sugestionado e estar em harmonia com os membros do grupo. Ele o faz por amor ao grupo cuja natureza dos laços libidinais entre os membros é da ordem da identificação. A hipnose distingui-se da formação de grupo por haver um número menor de participantes e por não haver identificação entre seus membros, esta apenas presente na formação de grupo. Isso explica maior sugestionabilidade em grupos do que na hipnose, pois existe influência recíproca entre seus membros.

Se por um lado no grupo há uma dupla vinculação: a identificação aos membros do grupo e a colocação do líder (objeto) no lugar de ideal do eu, por outro, na relação hipnótica apenas se verifica a alocação do objeto (hipnotizador) no lugar do ideal de eu. Freud define a fórmula libidinal (ligação dos laços) para a formação em grupo: "Um grupo primário desse tipo é um certo número de indivíduos que colocaram um só e mesmo objeto no lugar de seu ideal do ego e, consequentemente, se identificaram uns com os outros em seu ego" (1921/1996, p.126). Assim a condição para formação de um grupo deve-se ao que os membros têm em comum, um interesse num objeto, uma inclinação emocional semelhante em uma situação ou em outra.

Freud enfatiza que a ideia dominante veiculada pelo líder pode ser negativa, o que se transporta a situação na SAP "... o ódio contra uma determinada pessoa ou instituição poderia funcionar exatamente da mesma maneira unificadora e evocar o mesmo tipo de laços emocionais que a ligação positiva" (1921/1996, p.111).

Uma característica do grupo pode ser a crueldade e intolerância para os que não pertencem a ele. Frequentemente se observa que quando há formação de grupo em casos de SAP, ela é mais difícil de ser desfeita, pois o poder de influência de um irmão sobre o outro dá maior coesão à programação. O alienador conta com a ajuda dos filhos em alienarem uns 
aos outros, intensificando o efeito de seu projeto alienador. Dessa forma, Gardner sugere que nestes casos, as entrevistas, terapias e visitas ao genitor sejam feitas separadamente com cada criança para que esse poder de influência recíproca seja quebrado. Ao desfazer o funcionamento de grupo convoca-se mais facilmente a singularidade dos sujeitos que se encontram numa condição de superalienação.

Na psicanálise, o conceito de transferência surgiu como necessidade ética e epistêmica de: 1) fundamentar as condições de possibilidade do fenômeno de sugestão 2) de apresentar um modo operatório mais eficaz e ético ao tratamento do que a própria sugestão. Deve-se, portanto, considerar a transferência e sua relação com a sugestão para compreender o que se constitui por SAP.

Como afirmado anteriormente, apesar da sugestão realizar seus efeitos na SAP, esta não pode se resumir exclusivamente à sugestão por ser apenas um dos elementos constitutivos da transferência.

Lacan ressitua a transferência a partir da crítica sistemática à noção de eu da Psicologia introduzindo-a pela diferença em relação à noção de sujeito na psicanálise. Relendo a teoria freudiana a partir dos registros do simbólico, imaginário e real situa o eu no registro do narcisismo e imaginário e o sujeito como sujeito do inconsciente no registro do simbólico. Esta diferença entre eu e sujeito permite distinguir que a comunicação se dá no campo do eu e funda a resistência, enquanto o desejo se refere ao campo do sujeito e diz respeito à enunciação, em que se insere o campo de pesquisa da verdade em psicanálise. Sobre a dimensão resistencial da transferência apontada por Freud, Lacan cita que enquanto na análise a transferência se transforma em resistência, fora da análise é um fator de êxito pois permite os laços.

Lacan afirma que a ação eficaz das intervenções analíticas não se sustenta a partir de uma doutrinação, de uma intervenção educadora ou de uma conviç̧ão intelectual vinda da superioridade de um Outro, mas "(...) do ato da palavra. Cada vez que um homem fala ao outro de maneira autêntica e plena há, no sentido próprio, transferência, 
transferência simbólica - alguma coisa se passa que muda a natureza dos dois seres em presença" (1954-55/1979, pag.130). Nesse sentido, a palavra do magistrado pode vir a ter um valor de ato que instaura uma separação, um corte no gozo do filho alocado no lugar de objeto de posse de um genitor.

Já a transferência imaginária é a que se situa como obstáculo e implica repetição das situações antigas e reintegração imaginária no qual a situação passada não é vivida no presente porque a dimensão histórica é desconhecida pelo sujeito. Da mesma forma, a palavra do magistrado quando não incide sobre o desejo pode vir a funcionar no seu sentido oposto, calcando mais a alienação e a repetição do sujeito.

Portanto, a transferência é abordada através da questão da palavra, pensada na vertente imaginária e simbólica, sempre na relação com o outro através da noção de discurso. A palavra é mediação e relaciona-se à realização na medida em que ela é mediação entre o sujeito e o outro. Quando o discurso cessa a palavra é mediação. A palavra é aquilo que resta ser dito e que prende o sujeito ao outro. Mas ela não se reduz ao imaginário. O sujeito é mais do que ele diz, abre-se a dimensão simbólica do sujeito e da transferência.

O sujeito fala através de uma forma alienada do eu, forma egoica ou narcísica, isto é: produz um discurso como unidade imaginária que se dirige ao outro, duplo especular, constituindo a vertente imaginária da transferência distinta da vertente simbólica cujo endereçamento visa o Outro e situa a palavra como simbólica. $O$ que se pode extrair desta concepção a respeito do laço que caracteriza a relação entre genitor alienador e criança alienada? Qual a relação do laço de transferência e as características positivas e negativas da relação amorosa?

Lacan articula a transferência ao amor. Distingue o amor e objeto do amor. Enquanto o primeiro liga-se a paixão pertencente ao registro do imaginário e da relação do eu, o objeto do amor, chamado de Eros, define como: "presença universal de um poder de ligação entre os sujeitos, subjacente a toda a realidade em que se desloca a análise" (1954- 
$55 / 1979$, p.133). Coloca que é necessário "encontrar a estrutura que articula a relação narcísica, a função do amor em toda sua generalidade e a transferência na sua eficácia prática" (1954-55/1979, p.134) e que a transferência se exerce ao mesmo tempo em vários registros, o simbólico, o imaginário e o real.

Para Lacan, a ordem narcísica em Freud corresponde ao registro imaginário onde o "outro tem para o homem valor cativante, pela antecipação que representa a imagem unitária tal como é percebida, seja no espelho, seja em toda realidade do semelhante (...) outro, o alter ego, confunde-se mais ou menos segundo as etapas da vida com o Ich Ideal [Eu Ideal], esse ideal de eu." (1954-55/1979, p.148), alienação fundamental, imagem refletida de si mesma - o Eu ideal. A identificação narcísica do segundo narcisismo é a identificação ao outro que, no caso normal, permite ao homem situar com precisão a sua relação imaginária e libidinal com o mundo, correspondendo ao Ideal de eu.

Lacan apela ao narcisismo para explicitar a equivalência do objeto e do ideal de eu na relação amorosa: "o objeto amado é, no investimento amoroso, pela captação que ele opera do sujeito, estritamente equivalente ao Ideal de Eu" (1954-55/1979, p.149).

É por esse motivo que há na sugestão, na hipnose essa função econômica tão importante que é o estado de dependência, verdadeira perversão da realidade pela fascinação do objeto amado e sua sobre-estimação. (Lacan, 1954-55/1979, p.149)

A criança ama inicialmente o objeto que satisfaz suas pulsões de eu, isto é, a pessoa que se ocupa dela. O narcisismo primário da criança tem a ver com o modo como os pais a veem: sua Majestade - a criança e o que os pais fazem dela na medida em que projetam o ideal. Esse ideal recalcado projeta um novo Ideal para o qual vai agora o amor de si, de que gozava a criança no eu real. A criança não quer renunciar à perfeição narcísica da infância e procura recuperá-la na forma nova de seu ideal do eu. Essa nova forma de ideal é o que se projeta diante de si como ideal. Um narcisismo está no plano imaginário e outro no plano do simbólico, 
porque a exigência do Ideal de eu toma seu lugar no conjunto das exigências da lei. Lacan ressalta no conjunto dos ideais uma instância que tem função de vigilância e de segurança ante o eu atual nomeada por Freud de supereu.

O desenvolvimento do eu consiste num afastamento do narcisismo primário e engendra um vigoroso esforço para recuperá-lo. O "ideal de eu comanda o jogo de relações de que depende toda relação a outrem. E dessa relação a outrem depende o caráter mais ou menos satisfatório da estruturação imaginária" (Lacan, 1954-55/1979, p.165).

Assim como há dois narcisismos, Lacan propõe dois amores: Ágape quando o objeto amado é o eu ideal e Eros quando o objeto amado é o ideal de eu. Ele concebe o amor imaginário como o que provoca uma verdadeira subdução do simbólico, uma espécie de anulação, de perturbação da função do ideal do eu. Esse é o amor reforçado na SAP. O amor que reabre a porta à perfeição. Nesse nível, o "amor se torna mortal, pois é seu próprio eu que se ama no amor, o seu próprio eu realizado a nível imaginário". (Lacan, 1954-55/1979, p.167).

Freud havia descrito o eu, em "O ego e o id" (1923/1996), como sendo feito de sucessivas identificações com os objetos amados que the permitiram tomar a sua forma. Lacan esclarece que é no outro, que algo aparece e permite ao sujeito re-projetar, re-compor, nutrir em algum lugar, a imagem do Ideal de eu. Cada vez que o sujeito é cativado por um semelhante, o desejo volta ao sujeito. Isto é, cada vez que se produzem identificações objetais do Ideal de eu, aparece a Verliebtheit - paixão amorosa ou enamoramento. "A diferença entre Verliebtheit e transferência é que a Verliebtheit não se produz automaticamente - é preciso certas condições determinadas pela evolução do sujeito" (Lacan, 1954-55/1979, p.198). A cativação dessa fascinação da criança pelo alienador é por ele dirigida em função de uma obstinação vingativa. Ela vem a reforçar na criança o registro do imaginário dando condições para uma superalienação fazendo uma redução do sujeito, engajando-o no campo do amor-engano, puro invólucro imaginário. 
A transferência neste ponto é definida como fenômeno fundamentalmente imaginário, forma de Verliebtheit, fascinação imaginária, enamoramento. O amor tomado enquanto fenômeno imaginário que provoca uma espécie de anulação do simbólico, uma perfuração da função do eu. A transferência enquanto fenômeno imaginário é o ponto no qual se focaliza a identificação do sujeito quanto à imagem narcísica. Como o eu se forma por identificações, é por essa via que se produz o enamoramento: identificação ao objeto amado enquanto complemento da imagem de si, Eu ideal. Lacan define o amor como necessidade de passar pelo outro para captar-se enquanto eu. E antes que o desejo aprenda a se reconhecer como símbolo.

A relação imaginária primordial dá o quadro fundamental de todo erotismo possível. É uma condição à qual deverá ser submetido o objeto de Eros enquanto tal. A relação objetal deve se submeter sempre ao quadro narcísico e se inscrever nele. Ela o transcende certamente, mas de maneira impossível de realizar no plano imaginário. É o que faz para o sujeito a necessidade do que chamarei amor. (Lacan, 1954-55/1979, p. 202)

A imagem narcísica passa para o plano da Verliebtheit no transbordamento da libido da imagem do eu (amor a si) para a forma do ideal (Eros), isto é, "a imagem narcísica cativante, alienante no plano imaginário, encontra-se investida da Verliebtheit, que se destaca fenomenologicamente do registro do amor" (Lacan, 1954-55/1979, p.209). A reversão dessa libido implica uma viragem instantânea do amor e ódio tal como se vê no ódio do filho ao genitor alienado ao qual antes tinha afeição. Dissolvendo as amarras da palavra, o sujeito pode aceder ao desejo e perceber as imagens captadoras que estão no fundamento da constituição do eu, que na SAP se reinstalaram a partir do discurso do alienador. Isso porque a técnica da sugestão "produz no sujeito uma relação de miragem imaginária consigo mesmo, para além do que o vivido cotidiano lhe permite obter. Tende a criar artificialmente, em miragem, a condição fundamental de toda Verliebtheit" (Lacan, 1954-55/1979, p.211)

Por conseguinte na Verliebtheit trata-se de uma miragem, uma ilusão de unidade, de completude, o outro sendo depositário das 
idealizações como eu ideal. Idealização que resgata o narcisismo perdido, a perfeição, quando o sujeito, ele próprio era o seu ideal. Sendo amado se é perfeito, mas se depende do amante que o toma como maravilhoso, daí o ilusório nesse amor que retém o outro em uma miragem e na qual seu desejo não pode ser reconhecido. A transferência como aquilo que se produz a partir do momento que um se dirige ao outro desencadeia um discurso que é da mesma natureza que o amor. Ela está no "ponto em que se focaliza a identificação do sujeito com relação à imagem narcísica". (Lacan, 1954-55/1979, p.211).

O que o sujeito busca nesse plano, na análise e na vida, é ser amado e de nenhuma forma saber sobre a verdade de seus sintomas, pois preso na questão: sou amável? A contribuição original de Lacan ao elaborar o conceito de transferência foi ligá-lo à questão da verdade, por isso distingue aqui o plano dos desejos capturados na relação especular de um desejo possível pelo simbólico da palavra, o desejo enquanto reconhecimento do desejo do Outro, pelo vetor Outro - sujeito, vertente simbólica da transferência, na qual se coloca a interpretação que permite o sujeito sair da paixão da ignorância - organização de um conjunto de afirmações e negações, que situam o desconhecimento de sua verdade e que desprega a noção de transferência da ideia de afetos e sentimentos.

Enquanto dimensão em que o desejo do sujeito é integrado ao plano simbólico, a relação narcísica no plano imaginário é a condição fundamental da Verliebtheit que pode ser desfeita pela palavra que é o que se constata com o poder da palavra do juiz ao desmoronar a SAP. A criança passa não recusar mais o genitor alienado. Assim é pela báscula do desejo, que o reconhecimento pode se dar, pois as oscilações das identificações e da libido, via fala, podem reconstruir a história do eu. Basculando entre o eu ideal e o ideal do eu, entre Verliebtheit e transferência, entre o imaginário em que a libido paralisa, reinvestida narcisicamente ou depositada em um outro, travada a báscula, a fala que acede ao desejo não mais se faz, pois a criança está petrificada numa alienação do Outro. 
Na SAP o reforçamento da alienação é feito a partir da sugestão e de um sobre-investimento narcísico na criança pelo alienador. Para isto ele a toma como um ser excepcional e único, servindo a criança como um rei, com total submissão às suas demandas, via de regra, tornando a criança um pequeno tirano, tal como se no narcisismo primário fundante da constituição subjetiva. Não raro, tais crianças apresentam importantes dificuldades em reconhecer os limites, o outro semelhante, a lei social, podendo até mesmo a chegar a níveis elevados de crueldade (geralmente em relação ao genitor alienado). Isso indica o não reconhecimento da alteridade elemento que funda a lei subjetiva e simbólica desde onde se originam as leis da civilização.

$\mathrm{O}$ amor se distingue do desejo porque se dirige ao ser numa perspectiva que vai além de suas duas faces: amor ao outro porque se parece a mim e amor ao outro porque cuida de mim. Ou seja, além do amor paixão que se constitui no plano imaginário, há o amor como dom ativo que se constitui no plano simbólico, 0 amor que se realiza simbolicamente na palavra. "Sem a palavra enquanto ela afirma o ser, há somente Verliebtheit, fascinação imaginária, mas não há amor. Há amor sofrido, mas não o dom ativo do amor" (Lacan, 1954-55/1979, p.315)

Também "há uma dimensão imaginária do ódio, na medida em que a destruição do outro é um pólo da estrutura mesma da relação intersubjetiva" (Lacan, 1954-55/1979, p.315) O amor aspira desenvolvimento do ser enquanto o ódio quer seu rebaixamento, sua desorientação, seu desvio, sua negação. "É nisso que o ódio como no amor, uma carreira sem limite" (Lacan, 1954-55/1979, p.315). Assim, amor e ódio são duas vias de realização do ser, ambas ligadas à imagem. Essa imagem de si, o sujeito a encontra por intermédio do outro. Quando "o outro satura, preenche essa imagem ele se torna objeto de um investimento narcísico que é o da Verlibiebtheit" (Lacan, 1954-55/1979, p.321). Mas se o outro aparece frustrando o sujeito de seu ideal e da sua imagem, engendra a tensão destrutiva máxima. É por um "nadinha" que o amor se revira em ódio. Nesse sentido, a tentativa do genitor alienado 
trazer uma referência simbólica, a alteridade pode até mesmo provocar mais ódio na criança alienada enfeitiçada na fascinação amorosa, na promessa de completude do alienador.

Para Lacan tanto o amor como ódio podem ser tomados em sua vertente imaginária caracterizada pela reversão. Tal observação permite entender a fascinação da criança pelo alienador e o ódio ao genitor alienado, sintoma este definido por Gardner como ausência de ambivalência. Na medida que o genitor alienado visa barrar a criança desse amor fascinação com alienador, o ódio se reforça. A partir deste mesmo ponto pode-se compreender também a eficácia da campanha de desmoralização e a sustentação deliberada da criança ao lado do alienador diante do conflito parental.

A transferência em sua condição de possibilidade da análise não é nem intelectual e nem afetiva, mas se situa na dimensão da ignorância e o analista deve ocupar o lugar da ignorância docta que abre a via de saber para o sujeito "Deve engajá-lo numa operação dialética, não dizer-Ihe que se engana, porque está forçosamente no erro, mas mostrar-Ihe que fala mal, quer dizer que fala sem saber, como um ignorante, porque são as vias de seu erro que contam" (Lacan, 1954-55/1979, p.317). Enquanto a sugestão exercida pela captação da imagem do outro, permite a ilusão de completude e integridade no lugar do desamparo original afastando o sujeito de sua condição desejante.

A transferência em sua vertente simbólica abre as vias do saber e permite acesso à verdade dos sintomas. Em sua vertente imaginária, a transferência é obstáculo à passagem da palavra inconsciente que desde o Outro faria emergir o sujeito em sua dimensão de verdade, o que Lacan chama de palavra plena. A palavra pela qual poderia realizar-se, pois implica o reconhecimento do desejo inconsciente. Nesse sentido a palavra do magistrado pode apontar e até mesmo recuperar a dimensão da verdade do desejo sujeito. Na SAP, constata-se que não há manifestação do sujeito do desejo, pois sua palavra é totalmente alienada no discurso do alienador o que traz importantes consequências para seu devir. Este 
apontamento traz uma importante direção ao tratamento da questão pelo judiciário em casos de alienação do desejo da criança em razão da programação de um dos genitores.

No Seminário 5 "As formações do inconsciente" (1999/ 1958[1957]), a partir da doutrina do significante e sua função no inconsciente, Lacan situa transferência e sugestão no grafo do desejo e coloca que há um embaraço na relação das duas, pois Freud assume que a transferência é uma sugestão separando-se apenas no tratamento analítico pela interpretação.

Lacan retorna ao texto de Freud "Psicologia de grupo e análise do ego" (1921/1966) e a partir dos três tipos de identificação propostos, apresenta as diferenças entre transferências e sugestão em termos de demandas. A noção de demanda é a novidade lacaniana para impedir a submissão do desejo à necessidade, redução operada pela Psicologia ao situá-lo como extensão do campo biológico e mantê-lo na dimensão simbólica e cultural da espécie humana. A demanda é o que surge como uma cunha que mantém a distância entre a necessidade e desejo, ambas carências, mas enquanto a primeira fica fora do campo psicanalítico, a segunda carência é ressituada no campo da subjetividade em sua dimensão de pura falta, falta do objeto do desejo segundo a elaboração freudiana e falta de significante na teorização lacaniana.

No texto "A direção do tratamento" (1998/1958), Lacan estabelece que o que se concebe como necessidade biológica passa pelo moinho das palavras da demanda. O que da necessidade fica transmutado e não articulado, na demanda permanece como um resto que é o desejo.

O desejo é aquilo que se manifesta no intervalo cavado pela demanda além dela mesma, na medida em que o sujeito articulando a cadeia significante, traz à luz a falta-a-ser com o apelo de receber o complemento do Outro, se o Outro é o lugar da fala, é também o lugar dessa falta... O que assim é dado ao Outro preencher, e que é propriamente o que ele não tem, pois também nele o ser falta, é aquilo que se chama amor, mas são também o ódio e a ignorância (p.633).

$\mathrm{Na}$ SAP, pode-se afirmar que quando a criança é chamada a completar o Outro, o cuidador encarna o Outro consistente apagando a 
sua falta. Uma resposta diferente ocorre na via desejo em que a falta é preservada. As duas respostas são encontradas na constituição do sujeito, mas na SAP o genitor alienador encarna Outro completo eliminando a possibilidade que um Outro - o genitor alienado ou outro do meio familiar represente a alteridade a partir do qual a criança poderia aceder ao desejo tornando-a presa de um gozo narcísico.

Toda demanda evoca paixões do ser, pois como articulação significante, única via para a satisfação da necessidade, se dirige ao Outro e se modula como demanda de amor. Esse oco que cava a demanda deve ser mantido para que o desejo se manifeste. "É a criança alimentada com mais amor que recusa o alimento e usa sua recusa como um desejo" (Lacan, 1958/1998, p.634). A "satisfação da necessidade aparece como engodo em que a demanda de amor é esmagada, remetendo o sujeito ao sono em que ele frequenta os limbos do ser, deixando que este fale nele" (Lacan, 1958, p.634), aniquilando assim o desejo, pois o ser da linguagem não é o não-ser dos objetos.

Quando o Outro se aferra a ideia de como satisfazer as necessidades, confunde cuidados com o dom de amor. Nessa operação reduz-se a demanda à necessidade. $O$ alienador assim o faz para aprisionar a criança numa relação dual cujo amor encobre o gozo da posse. Com extremos cuidados e discurso do amor em relação à criança, confunde os operadores do Direito principalmente quando o genitor alienado apresenta alguma fragilidade quanto ao papel de cuidador.

A partir da tríade necessidade-demanda-desejo se pode esclarecer a ambiguidade freudiana derivada do estabelecimento da transferência como sugestão, já que consiste na tomada de poder de um agente sobre o sujeito, possível pela própria estrutura da demanda que estabelece aquele a quem falta e aquele a quem deveria ter. Mas o analista não maneja a transferência desde o poder, pois a trata como uma suposição. O sujeito é distinto do eu, que se supõe dividido porque sujeito de um desejo sem sabê-lo, o que permite não encerrá-lo em sua demanda. Por isso a ética 
psicanalítica indica não ratificar nunca a demanda enquanto tal, ao contrário do que faz o programador.

Com isso o analista não favorece a confusão entre as duas possibilidades pela presença do Outro: transferência e sugestão, e esclarece os limites do hipnotizador, pois o que resiste é o campo do desejo. Todavia é isso que o alienador faz, maneja a transferência desde o poder, encarna o sujeito que sabe e ratifica a demanda.

Ora, se podemos interpretar a sugestão, é porque ela tem um segundo plano. A transferência em potencial está ali.... A transferência já é, potencialmente, uma análise da sugestão, ela própria é a possibilidade da análise da sugestão, é a articulação secundaria daquilo que, na sugestão, impõe-se pura e simplesmente ao sujeito. Em outras palavras, a linha do horizonte na qual se baseia a sugestão está ali, no nível da demanda, da demanda que o sujeito faz ao analista pelo simples fato de ele estar ali (Lacan, 1957-58/1999, p.439-440).

Lacan rejeita a redução da transferência à sugestão, pois a difere do uso de um poder. Ela se articula a cadeia significante diferente da sugestão que encerra o sujeito numa demanda imperiosa. Essa confusão entre a transferência e sugestão em Freud se liga ao fato da identificação ser regressiva.

identificação que sucede a essa visada do objeto como amado e que a substitui é a regressão.... na linha da sugestão que se faz a identificação com as insígnias do Outro como sujeito da demanda, aquele que tem o poder de satisfazê-la ou não satisfazê-la e que marca a todo instante essa satisfação com algo que é, no primeiro plano, sua linguagem, sua fala (Lacan, 1957-58/1999, p.441).

As regressões se escandem em identificações que thes são correlatas e que marcam os tempos, os ritmos. A regressão refere-se aos significantes da demanda que sustentaram "as frustrações em que o desejo se fixou (a Fixierung de Freud), é somente no lugar deles que o desejo é sujeitador" (Lacan, 1958/1998, p.641)

Deve-se diferenciar a demanda da demanda de amor para aprofundar a natureza da transferência e sugestão. A necessidade partindo da pulsão que é muda tem que se articular ao significante instituindo a demanda. A demanda de satisfação de uma necessidade realizada pela intervenção do Outro, se transforma em demanda de amor, 
pois o objeto que a pulsão rodeia pertence ao campo do amor. O que se abre da hiância entre a necessidade e demanda é o desejo.

Há entre transferência e sugestão - essa é a descoberta de Freud - uma relação: é que a transferência também é uma sugestão, porém uma sugestão que só se exerce a partir da demanda de amor, que não é demanda de nenhuma necessidade. (Lacan, 1958/1998, p.641)

Assim, a demanda ao subverter o plano da necessidade a introduz na ordem simbólica - da palavra e evoca a presença do Outro em sua satisfação se tornando demanda de amor. Por isso a transferência enquanto endereçamento da palavra ao outro se encontra entre o saber e o amor, pois se constitui como demanda de amor, enquanto a sugestão se encontra no nível da demanda de satisfação de uma necessidade, articulada ao que é da ordem do imaginário, do enamoramento, o que remete à universalidade do laço.

O que faz com que as duas se mantenham separadas é uma operação que implica a abstenção do analista possível pelo fato de que entre elas há o campo do desejo. Nunca ratificar a demanda, não satisfazê-la para dar lugar à manutenção do desejo é condição para haver sujeito e condição ética da análise, pois:

...basta que as coisas sejam permissivas no plano verbal para que o paciente fique satisfeito... E basta que ele fique satisfeito no plano da demanda para que se estabeleça irremediavelmente a confusão entre a linha da transferência e a linha da sugestão (Lacan, 1957-58/1999, p.442).

Constata-se na SAP um embaraço maior entre transferência e sugestão. A manutenção exclusiva da demanda de satisfação das necessidades pelo alienador esmaga a demanda de amor impedindo a hiância da qual surgiria o desejo. Essa operação do alienador, isto é, essa redução da demanda do amor a necessidade, confunde os operadores do Direito, pois frequentemente o genitor se mostra um excelente cuidador apontando negligência, maus-trados, inadequação no genitor alienado. Essa redução aqui apontada, isto é, um funcionamento burocrático e narcísico na função parental do programador visa promover o "bem-estar" 
da criança como sinônimo de amor. Deve-se ressaltar que Lacan traz uma precisão do amor ligado as vertentes do real, simbólico e imaginário. Então, o que nos discurso, no imaginário pode ser apresentar como um amor ao filho, não necessariamente liga-se ao desejo, ao dom do amor, ao amor conectado ao simbólico e real.

Há amor imaginário oriundo do narcisismo e situado como posse e há amor simbólico como dom ativo, que Lacan define como "Amar é dar o que não se tem" (1960-61/1991, p. 46) e que pertence ao domínio do não-ter, posição subjetiva de falta. Como afirma Lacan, dar o que se tem é uma festa, não é o amor, por isto, responder à demanda de amor dando alguma coisa sem metaforizar, não é um amor verdadeiro, é um engano, um logro. Mas também há a aspiração a ser amada pela criança a qual o alienador satisfaz com essa espécie de paixão amorosa que prende o sujeito em uma gaiola narcísica.

Lacan afirma que todo hipnotizador sabe que nenhuma sugestão, por mais bem sucedida que seja, apodera-se totalmente do sujeito porque algo resiste. O que resiste é o desejo, o desejo de ter o próprio desejo. Devido a esta fragilidade o alienador usa outras estratégias porque 0 efeito hipnótico da SAP desmorona quando se evoca o desejo da criança. No entanto, o desejo em sua estruturação é sempre desejo do desejo do Outro, desejo de ser desejado. Ele é sempre moldado pela demanda, pois o desejo do Outro permanece suspenso no inconsciente. Ou seja, para o desejo ser significado ele tem que passar por uma demanda e para tal ele precisa ser marcado por um símbolo - o Falo.

O fato da demanda só se constituir como tal na medida em que o sujeito é sujeito do significante é o que permite utilizá-la mal. Por isso não se deve confundir "a identificação com o significante onipotente da demanda (...) e a identificação com o objeto da demanda de amor" (Lacan, 1958/1998, p.641). Esta é também uma regressão e Freud faz dela a segunda modalidade de identificação. Nela está o exit que permite que se saia da sugestão. 
A identificação com o objeto como regressão, por partir da demanda de amor, abre a sequência da transferência.... a via em que poderão ser denunciadas as identificações que, detendo essa regressão, a escandem. (Lacan, 1958/1998, p.642)

Assim a transferência por si é análise da sugestão, na medida em que coloca o sujeito, com respeito à sua demanda, numa posição que ele deriva unicamente de seu desejo. Desejo que é sustentado pelo terceiro modo de identificação especificado pela indiferença do objeto. (Lacan, 1958/1998, p.646).

No seminário 8 , ao analisar o tema da transferência, Lacan privilegia a abordagem via do amor simbólico e situa uma dessimetria fundamental na relação do amor, pois existem duas posições - a do sujeito e a do objeto. (Lacan, 1960-61/1992, p.19-20). No amor ele define os parceiros como funções e não de dois sujeitos, daí a impossibilidade de haver intersubjetividade. Na análise do Banquete de Platão, ele distingue o amante e o amado e uma suposição de que o amado tem o que se busca - o agalma, objeto precioso. Ao pensar a transferência em sua relação com o amor, ele esclarece o engodo que existe quando se pensa que a transferência se dirige à pessoa, pois esta permite situar o agalma - um puro envelope de um vazio.

A transferência não é um fenômeno exclusivamente psicanalítico, "pois decorre do fato de que ela se manifesta na relação com alguém a quem se fala". (Lacan, 1960-61/1992, p.177). Na experiência analítica, da mesma forma que em outras manifestações transferenciais é sempre de amor que se trata no estabelecimento de uma relação. A transferência enquanto manifestação amorosa permite ter acesso não só a um ideal, mas ao desejo.

Pois o desejo, em sua raiz e sua essência é o desejo do Outro, e é aqui, falando propriamente, que está a mola do nascimento do amor.... desejo que se manifesta sempre na medida em que não sabemos.... É na medida em que não sabe o que Sócrates deseja, e que é o desejo do Outro, é nessa medida em que Alcibíades é possuído.... por um amor.... amor de transferência, e remetê-lo ao verdadeiro desejo (Lacan, 1960-61/1992, p.180) 
A partir do colocado precisa-se ressituar a SAP, pois não basta dizer que se trata de um amor imaginário e que seu agente impede a separação do Outro e o acesso ao desejo para justificar os efeitos no laço social e transferencial. Lacan situa a posição do analista como a de Sócrates que partindo do não saber engaja o sujeito em relação ao seu desejo, pois abre a pergunta pelo desejo - "O que ele quer?". Na SAP, o alienador não parte do não saber, mas sim do saber sobre a criança, uma certeza de que ele sabe tudo sobre o filho e este saber é idêntico à verdade, posição que o afasta do amor transferencial, aquele que permitiria o acesso à verdade desejante.

No seminário 11 (1964-65/1988), Lacan afirma que a transferência não se encontra na dependência da situação analítica, mas é um fato de estrutura. A transferência não se reduz à relação do sujeito com o analista no sentido da intersubjetividade. Há transferência por haver o campo do outro que está lá desde sempre. A transferência diz respeito a todas as relações do sujeito, todos os seus laços, dado que há inconsciente, o que chamamos sujeito é sempre um correlato necessário e velado do eu. A transferência é a atualização da realidade do inconsciente em seu modo infantil de funcionamento, assim ela realiza o discurso do inconsciente.

$\mathrm{O}$ eu, o carro chefe dos laços em geral, tem como fundamento o ideal do eu, aquele que se refere ao enamoramento. $O$ que se elide nos laços, diferentemente da especificidade do laço que se produz numa análise que visa o lugar original do sujeito, é o saber sobre a falta e sua potência operativa. Assim, a alienação é o destino do sujeito, ela supõe a vacilação entre a petrificação e a indeterminação. O sujeito da fala é sempre alienado, alienado no Outro, nos significantes do Outro, pois antes de se constituir como falante ele já é falado, sujeito alienado que perdeu seu ser e está dividido.

Mas o fundamental na operação de constituição do sujeito passa a ser não só a operação de alienação, mas também a de separação, em que se vê "despontar a transferência" (Lacan, 1964/1985, p. 202). Segundo Soler é um ato do sujeito, "um querer separar-se da cadeia significante" 
(1997, p.62). Nessa escolha, ao se separar, o sujeito ataca a cadeia significante e se engendra a partir de duas faltas:

Uma falta é, pelo sujeito, encontrada no Outro, na intimação mesma que Ihe faz o Outro por seu discurso. Nos intervalos do discurso do Outro, surge na experiência da criança, o seguinte, que é radicalmente destacável - ele me diz isso, mas o que é que ele quer? (Lacan, 1964/1985, p. 203).

Se o desejo desliza no intervalo da cadeia significante, o desejo do Outro é aprendido pelo sujeito naquilo que não cola, nas faltas do discurso do Outro, e todos os porquês da criança testemunham isso e colocam em prova o adulto "porque será que você me diz isso? .... ressuscitado de seu fundo que é o enigma do desejo do adulto". (Lacan, 1964/1985, p. 203). Para responder, o sujeito traz a resposta da falta antecedente de seu próprio desaparecimento, que ele situa no ponto de falta percebida no Outro. "O primeiro objeto que ele propõe a esse desejo parental cujo objeto é desconhecido, é sua própria perda - Pode ele me perder?" (Lacan, 1964/1985, p. 203). A criança manifesta a fantasia de sua morte em relação ao amor de seus pais. Assim uma falta recobre a outra, e é nessa dialética dos objetos do desejo, no que faz junção do desejo do sujeito com o desejo do Outro, que não é respondido diretamente, uma falta engendrando a outra.

O sujeito parece dividido. Do lado do Outro ele aparece como sentido, mas alienado nos significantes que recebeu do Outro (S1-S2 articulados) o que lhe permite dizer "eu sou isto". Do lado em que emerge o sujeito, há o sem-sentido, ele é condenado ao silêncio, à desaparição (o S1 aparece sozinho do lado do sujeito, desarticulado do S2), a afânise do sujeito. Portanto, S1 cria o sujeito ao mesmo tempo em que o apaga. O sujeito vive condenado a estar entre um e outro lado - entre a afânise ou se apagar na alienação. Assim, o sujeito é aquele que se manifesta no intervalo entre S1 e S2. Na separação, o sujeito está em equivalência com o objeto a. Essa nova dimensão do sujeito: quando não é sujeito do significante, quando não está assujeitado ao significante, o sujeito é o objeto. 
A transferência é definida a partir do sujeito suposto saber ${ }^{13}$ e o efeito da transferência como o amor referenciado ao campo do narcisismo: amar é, essencialmente, querer ser amado. Comumente a transferência é tratada como semelhante a conceitos como o de erro, ilusão, fantasia. Mas Lacan diz que o que é essencial é fazer surgir o domínio da tapeação, no discurso ela tem alguma chance de ter sucesso "ao persuadir o outro de que ele tem o que nos pode completar, nós garantimos de poder continuar desconhecer precisamente aquilo que nos falta. O circulo da tapeação, enquanto que não-nomeado, faz surgir a dimensão do amor" (Lacan, 1964/1985, p.128).

A partir desse ponto pode-se entender a eficácia da SAP e a possibilidade de sua dissolução. A transferência é um fato de estrutura, pois parte da falta estrutural que constitui o sujeito que se endereça ao outro em busca da completude e nesse movimento enlaça o saber e o amor. É a relação do agente com o saber que pode fazer a virada em direção ao amor de transferência ou sugestão, ou seja, que se pode revelar ou não o círculo de tapeação que surge na dimensão do amor. A pessoa a qual a criança endereça a fala ocupa o lugar do saber. Ela a amará por crer que ela detém um saber sobre seu ser. Se, além disso, o genitor alienador encarnar o S1 (significante isolado da cadeia) ${ }^{14}$ ela situará não como suposto saber, mas como detentor da verdade do sujeito, vindo a funcionar hipnoticamente capturando o sujeito através das imagens e significantes oferecidos.

\footnotetext{
${ }^{13}$ A fórmula lacaniana "sujeito suposto saber" diz respeito ao fato do sujeito desconhecer seu próprio desejo, seu inconsciente. Para que ele possa saber do seu desejo insabido, ele endereça sua fala a um Outro ficcional (pois criado pelo sujeito), através do qual passam-se todas as suas relações. O Outro para o sujeito, se confunde com o outro semelhante, por ser um lugar para o qual o sujeito transfere seu saber. Há uma ilusão de que o outro sabe do desejo do próprio sujeito. Para Lacan esta definição marca efeitos na transferência, por exemplo, pode-se entender a susceptibilidade da criança ao supor um saber ao genitor que utiliza desta ilusão para e manejar a transferência com fins de instalar a SAP,

${ }^{14} \mathrm{O}$ alienador comandar do S1 do sujeito, isto é, encarnar o Outro consistente da criança (pois todo neurótico quer crêr que o Outro é consistente e não uma ficção por ele criada), encarna o Outro superegoico, o Outro do mandato de gozo pois sua palavra ao ser enunciada adquire função de ato, tem um valor de mandato e impõe uma submissão.
} 
Ao se agarrar à referência daquele que olha, o ideal de eu aparece esse ponto em que o sujeito deseja comprazer-se em si mesmo. É somente com a identificação com o objeto a que se pode introduzir uma separação nessa identificação: "pela função do objeto $a$, o sujeito se separa, deixa de estar ligado à vacilação do ser, ao sentido que constitui o essencial da alienação" (Lacan, 1964/1985, p. 243). A transferência então funciona no sentido de manter a distância entre o ponto do ideal de eu e o objeto a, mas para "que o analista funcione como suporte do a separador, é preciso antes que ele caia do lugar de idealização" (Lacan, 1964/1985, p. 258)

É esse ponto que o alienador impede que ocorra não somente porque se recusa cair do lugar de idealização, mas principalmente porque se coloca como o único a vir poder se colocar no ponto desde onde o sujeito se vê como amável. Daí a campanha difamatória contra o genitor alienado, pois tem necessidade de eliminar a alteridade, pois nenhum outro poderá vir a ser representante deste lugar onde a criança se oferece como objeto para ser amado.

Assim a transferência pressupõe sugestão, mas o fato de haver sugestão não implica que haja transferência, pois é na transferência que existe a possibilidade de analisar o que há de sugestão no laço. No seminário 16, "De um outro ao Outro" (1968[1969]/2008), Lacan introduz o conceito de discurso para articulá-lo como aquilo que dá origem a transferência e que possibilita situar a operação de separação que o analista efetua no amor de transferência por se situar objeto a separador desfazendo o efeito de tapeação e possibilitando ao sujeito acesso à verdade.

Com a formulação dessa topologia da transferência a psicanálise pode se tornar uma ética que oriente a práxis no campo do Direito desfazendo os efeitos de hipnose que há no laço entre o alienador e a criança. O sujeito precisa desse desvio, desse Outro como uma alteridade, para instituir um lugar de saber e uma suposição de um sujeito que pudesse representá-lo - um Sujeito Suposto Saber de sua verdade. Esse 
Outro do saber por estrutura é um lugar vazio desde onde se articula um a saber que é sempre incompleto portanto o outro não sabe, mas a transferência se funda nisto - estrutura de ficção do Outro que o neurótico recusa saber. Há uma impostura já que não há esse saber completo e menos ainda um sujeito que soubesse do que se trata, mas é exatamente isso que permite que na percepção da falha no discurso do Outro parental se dê o surgimento da verdade do desejo.

O sujeito ama o saber, pois este indica o Outro em sua falta e em sua condição desejante e na medida em que os pais o representam são também amados. É nesse sentido que a transferência se situa entre o desejo e o amor, ambos regidos pela falta. Por amar o Outro do saber a criança se identifica aos significantes enunciados no discurso parental e aos significantes da demanda do Outro tomados no registro do amor, dessa forma ela se vê como amável.

Assim pode-se explicitar por que meios um genitor consegue fazer essa regressão da demanda à necessidade eliminando o efeito da falta no campo do Outro e como essa alteridade pode ser adulterada a partir de sua própria condição de existência.

A alteridade se dá em dois níveis - a oferta de uma imagem e de significantes que vem do Outro através das figuras que encarnam o Outro da criança. Além dos significantes, o genitor pela sua presença encarna também o objeto agalmático, objeto do desejo na fantasia, objeto que por representar o encobrimento da verdade da estrutura adquire um brilho, uma fascinação que prende a criança em uma relação de amante-amado. Isso tem como efeito uma torção na transferência ao genitor, pois se oferece também como objeto amado fazendo coincidir o Ideal e o objeto.

Assim, como na situação analítica, a transferência também é tomada no registro do semelhante (transferência imaginária) além de simbólica. Lacan retomou o impasse freudiano no que se refere à relação da sugestão com a transferência para precisar que uma se refere à demanda de satisfação de uma necessidade (ordem do imaginário, do enamoramento e da universalidade do laço) e a outra é demanda de 
amor, a demanda que o sujeito faz ao analista pelo simples fato de ele estar ali. (Escritos, 1992, p.440)

A eficácia do alienador se dá porque encarna o Outro do sujeito um Outro consistente e faz coincidir o objeto e ideal para instalar, através da sugestão, um discurso alienado a seu desejo que se coloca como vontade de gozo. Dessa forma exclui o outro genitor da posição de agente do discurso para a criança e este deixa de instalar o inconsciente - os significantes ideais para a criança. Isso é possível porque a transferência entre a criança e o genitor alienado é desfeita pelo alienador e ela passa a responder apenas ao ideal e as demandas transmitidas por ele.

Para o filho apenas se ver como amável a partir dos ideais de um genitor deixando de responder ao outro genitor, opera-se uma redução no campo da alteridade, das figuras que têm função de representância do Outro. Ao outro genitor é negada a condição de suportar a função do falo, o que fecha a via da transferência, pois há uma regressão da identificação às demandas primitivas do sujeito. A criança na SAP regride sempre ao primeiro tempo do Édipo no qual o genitor transmite e fixa os significantes do Ideal que desconectados do desejo adquirem valor de mandato supergoico. Considera-se assim a gênese SAP na psicanálise a partir da constituição do sujeito no qual haveria uma exageração da alienação fundamental dificultando a separação pela apresentação de uma demanda imperiosa do alienador associado a estratégias como retirada de amor, superproteção, permisividade ou ameaça. Mas a eficácia do alienador não pode ser explicada pela gênese e sim pela estrutura na qual se dá a relação do sujeito ao Outro.

SAP comumente é apontada como sinônimo de falsa implementação de memórias. Embora para psicanálise toda memória seja falsa, isso pode ser reinterpretado pela regressão da identificação à demanda operada pelo alienador após dissolver a transferência com o outro genitor, propondo-se em lugar de sedução e fascínio em que o objeto e o ideal coincidem, lugar do hipnotizador no campo da transferência. 
Uma vez que se deu uma torção e manejo da transferência que prejudica o curso da separação do Outro, a criança só poderá tomar a palavra que vem do outro alienador como fará dela sua própria palavra e mensagem. Nesse sentido, a afirmação de Gardner de que pai e mãe podem induzir a SAP pode ser estendida para qualquer outro do circulo afetivo de uma criança desde que encarne o Outro ideal e se ofereça como objeto pode fazer uso da transferência como poder instalando significantes com os quais a criança se identificará para se manter no circuito de uma fascinação amorosa.

A transferência, contudo, não é o amor embora a ele se conecte. $O$ amor também assume a forma imaginária, simbólica e real. Em sua dimensão imaginária, narcísica, no amor-paixão se dá pelo investimento amoroso do objeto amado equivalente do Ideal de eu, pela captação que ele opera do sujeito. Esse amor revela uma face mortífera, pois é o próprio eu que se ama no amor, seu eu realizado no nível imaginário, capturado através do outro antes que o desejo aprenda a se reconhecer como símbolo, como palavra.

Na SAP, o Outro do amor que o genitor propõe é da ordem do amorpaixão, retendo a criança numa dupla amante-amado ao lhe permitir que recomponha a imagem do Ideal de $\mathrm{Eu}$, cada vez que é cativado pelo semelhante. A transferência assume aqui a forma de uma Verliebtheit (enamoramento), amor em sua face imaginária que opera uma anulação do simbólico ao criar artificialmente em miragem excluindo o terceiro, o diferente por isso aparece o ódio ao genitor alienado, pois ele representa o diferente.

A transferência não é o amor, mas se conecta a ele naquilo que na neurose se constitui como ponto de ignorância - seu não saber do desejo recalcado e que o leva a amar aquele que sabe. Por isso, aqueles que representam figuras do Outro para a criança podem usar o poder da transferência e influenciar o destino do sujeito. Nesse ponto Freud deixa claro que a sugestão como fenômeno se subordina a transferência como razão. 
Concluindo a transferência diz respeito a todas as relações do sujeito, todos os seus laços, dado que há inconsciente. Na medida em que o real, o objeto a é aquilo que faz objeção ao laço e que remete a questão da fantasia tem-se que articular a transferência, identificação e fantasia, para ampliar a explicação da eficácia da SAP .

\subsubsection{Articulação entre fantasia, identificação e transferência na SAP}

A transferência foi situada como um fenômeno geral do funcionamento da mente, universal e espontâneo, que consiste em unir o passado com o presente mediante uma falsa ligação que superpõe os desejos pretéritos implícitos nas fantasias inconscientes e vinculadas aos objetos do passado, sobre os objetos atuais.

$\mathrm{Na}$ conferência 23, "Os caminhos da formação dos sintomas" (1917[1916a]/1996), Freud afirma que os neuróticos criam substitutos das satisfações frustradas realizando uma regressão da libido ao ponto de fixação libidinal do período da infância. Isto revela "que os neuróticos estão ancorados em algum ponto de seu passado, no qual sua libido não se privava de satisfação, no qual eram felizes" (p. 367) e retrocedem até o tempo em que eram bebês de colo. O sintoma repete essa forma primitiva de satisfação deformada pela censura, que retrocede ao tempo do infantil na qual a libido está fixada e que reaparece em cenas que são construções decorrentes de experiências onde os desejos são modelados, chamadas por Freud de fantasias.

Essa invenção - a fantasia aparece separada da realidade objetiva, mas tem valor de verdade para o sujeito. Embora falsificadas, correspondem a uma verdade histórica, "as fantasias possuem realidade psíquica, em contraste com a realidade material.... no mundo das neuroses, a realidade psíquica é a realidade decisiva". (Freud, $1917[1916 a / 1996$, p.367). 
Freud afirma que se constata também o domínio da fantasia na neurose na criança. As neuroses de crianças são muito mais comuns do que se supõe. Muitas vezes, elas deixam de ser notadas, são consideradas sinais de uma criança má ou arteira, muitas vezes, também, são mantidas em estado de sujeição pelas autoridades responsáveis pelas crianças; porém, sempre podem ser reconhecidas, retrospectivamente, com facilidade. "Fantasiando retrospectivamente dentro dessas épocas mais primitivas um objeto desejado, a criança se poupa da vergonha de se haver masturbado" (Freud, 1917[1916a]/1996, p.372). Isto quer dizer que a criança se apega ao enredo imaginário da fantasia e acredita que um adulto a seduziu o que a leva a fazer narrativas com a figura do sedutor. Nesses enredos torna-se comum o pai ser a figura frequente do sedutor, o que pode resultar em acusação de natureza imaginária para encobrir a atividade autoerótica.Freud adverte que embora a acusação responda a construção fantasmática, nem todo abuso sexual pertença ao reino da fantasia:

Se ocorrerem na realidade, não há o que acrescentar, mas se não encontrarem apoio na realidade, são agregados a partir de determinados indícios e suplementados pela fantasia... O resultado é o mesmo, e, até o presente, não conseguimos assinalar, por qualquer diferença nas consequências, se foi a fantasia ou a realidade aquela que teve a participação maior nesses eventos da infância. (Freud, 1917,[1916a]/1996, p. 372).

O reino mental da fantasia é uma reserva natural afastada da realidade a qual a libido utiliza para encontrar os pontos de fixação e revestir de catexias regressivamente obtendo satisfação. O caminho que leva da insatisfação à neurose implica afastar-se da realidade e transferir todo o interesse e libido para as construções plenas de desejo da vida de fantasia.

Ao estabelecer a fantasia alicerçada no conceito de realidade psíquica, realidade relativa a cada sujeito, pois derivada de uma interpretação subjetiva, Freud sublinha o inconsciente como bússola para as escolhas do sujeito. À medida que o inconsciente determina o sujeito a 
partir da constituição da fantasia, faz com que ele vislumbre o mundo sob esta ótica fantasmática.

O fato de que o inconsciente, o recalcado e a memória se moldem pela fantasia permite criticar a crença de que a criança em sua fala diz sempre a verdade, pois incapaz de mentir. $E$ isso inclui também de tomar sua convicção e crença como índice de verdade. Enquanto o Direito opera com a verdade material, a psicanálise opera com a realidade psíquica. Este conceito demonstra que no campo da subjetividade não se separa a mentira da verdade. Isto traz importantes consequências para o diagnóstico da SAP.

Uma psicóloga concluiu no laudo que o pai era abusivo, pois a criança confirmou que o pai coçava seus genitais. Enquanto fez várias entrevistas com a mãe e avó, prescindiu da presença do pai na certeza e convicção apresentadas pela criança, mãe e avó materna. Descobriu posteriormente que a avó havia sido abusada pelo seu pai e que sua mãe desconhecia o fato. Verdade histórica que a criança revelava na fantasia de sedução pelo pai. Se os estudos na área da Psicologia apontam a repetição familiar de abusos ao longo das gerações de uma família, para psicanálise pode-se desvelar que uma falsa alegação de abuso pode surgir a partir de conteúdo projetivo da fantasia de uma pessoa que foi realmente abusada em sua infância.

A fantasia emoldura, enquadra a realidade de forma tal que uma é o avesso da outra, não se podendo mais falar senão da realidade psíquica. As fantasias possuem realidade psíquica, em contraste com a realidade material e por isso que no mundo das neuroses, a realidade psíquica é a realidade decisiva.

Em 1919, no texto "Uma criança é espancada", Freud nomeia como fantasia fundamental um ponto de inércia e que é equivalente do recalque originário. A fantasia inconsciente é o que determina para um sujeito sua realidade, através dela capta o mundo e institui o campo dos objetos, bússola importante no campo do desejo. Ela é o suporte não só do sintoma, mas do desejo. O objeto do desejo sendo conceituado como 
perdido, não terá ordem empírica, mas estatuto simbólico, o que implica a necessidade de uma construção para sua abordagem. A fantasia permite ao sujeito seguir as trilhas para objetificação do desejo, ou seja: o objeto do desejo é uma fantasia que na realidade é o suporte do desejo ou de um voto.

No texto "Análise terminável e interminável" (1937/1976), não se pode dissociar verdade e ficção, se deve tomar verdade e realidade psíquica como homogêneas; sendo a verdade definida como o limite do que o aparelho psíquico pode tolerar. "O aparelho psíquico não tolera o desprazer.... se a percepção da realidade objetiva traz desprazer, essa percepção - isto é, a verdade tem que ser sacrificada" (p.270). A percepção é efeito de uma interpretação já realizada, conduzida pelo saber inconsciente e reconhecida a posteriori. A verdade que é sacrificada na SAP é a da castração que indica a falta de objeto e na qual o alienador oferece objetos para o desejo via perversa, pois não se trata de relação de objeto e sim da falta de objeto que a fantasia como suporte do desejo indica sua trilha.

Assim desde Freud, a fantasia é uma atividade psíquica presente na vida corrente das crianças, em jogos, sonhos diurnos, e nas diversas produções lúdicas e artísticas, que podem em determinadas condições gerar sintomas neuróticos, pois se constituem no estado preliminar dos mesmos.

A fantasia desempenha um papel importante na sexualidade da criança e do adulto. No texto "Uma criança é espancada" (1919/1996) Freud apresenta uma frase que descreve uma cena imaginada como suporte da satisfação masturbatória - e examina suas relações com o sadismo, com o masoquismo, o complexo de Édipo e as questões da localização do sujeito nessa cena. No texto "Os instintos e suas vicissitudes" (1915b/1996), Freud afirma, em última instância, que a fantasia está referida ao desejo de receber uma satisfação sexual e 
amorosa por parte do pai através de uma série de substituições dos personagens (do sujeito e do pai) e uma série de inversões gramaticais.

A frase que descreve a cena que acompanha a masturbação "batese numa criança", enigmática a princípio, está vinculada com dois outros momentos prévios. Um deles suscetível de ser recordado - "o pai bate numa criança" e o outro é inconsciente e recalcado e tem um caráter masoquista, "eu sou espancado pelo meu pai". Freud esclarece que o "ser batido" só pode ser construído em análise e revela culpa e erotismo: "Não é apenas o castigo pela relação genital proibida, mas também o substituto regressivo daquela relação, e dessa última fonte deriva a excitação libidinal que se liga à fantasia a partir de então, e que encontra escoamento em atos masturbatórios" (1919/1996, p. 237).

Na frase "sou espancado" converge em culpa, o amor e figuras de autoridade. Ser maltratado, ser amordaçado, ser aviltado, ser sujado, ser negligenciado, ser forçado à obediência, entre outros são expressões de fantasias masoquistas, presentes na constituição subjetiva, que conjugam prazer no sofrimento, uma posição passiva de natureza feminina e a presença de uma figura de autoridade permitindo através do enlace do erotismo e amor uma satisfação sexual.

Lacan esclarece que a fantasia e suas 3 fases são descrições de posições frente à cena/enredo de maltrato e dor até atingir uma posição de apassivamento, modelo generalizável a partir do qual se tem os posicionamentos subjetivos. São três posições possíveis ou modalidades de participação subjetiva no roteiro fantasmático:

1) o agente (o adulto) da ação espanca

2) uma outra criança (objeto) se faz espancar

3) a criança que (olha) a cena de espancamento representa para si a situação dos maus-tratos

Configurando cenas que aparecem nas narrativas que podem ser enunciadas como:

I) Meu pai bate numa criança que é meu rival configurando a ação de bater com o significado de odiar. 
II) Eu sou espancado pelo meu pai. O pai continua batendo, mas a vitima se tornou a própria criança - a autora da fantasia, que atinge um grande prazer. Esta fase em que ser batido pelo pai equivale a ser amado pelo pai sustenta a excitação que força o onanismo. Ser batido é consequência do amor incestuoso ao pai, regressão do desejo incestuoso com uma satisfação.

III) Um adulto bate em um menino e eu olho. A pessoa que espanca nunca é o pai, aparece um substituto do pai e no lugar da criança aparecem várias crianças do sexo masculino. A fantasia agora é portadora de uma forte excitação que é sexual e conduz a satisfação onanística.

Lacan explicita que na frase "Eu sou batido pelo meu pai", a culpa derivada do prazer pelo triunfo sobre o rival da primeira fase da fantasia se inverte e se transforma em castigo, agora é o próprio sujeito maltratado. A culpa faz sucumbir ao amor do pai e por não haver renunciado ao gozo incestuoso leva ao castigo - ser batido, gozo masoquístico do sujeito. A fantasia "sou batido pelo meu pai" responde na estrutura ao que é da ordem do recalque primário.

A partir desse momento, a fantasia, em sua significação - refiro-me à fantasia em que o sujeito figura como a criança espancada -, torna-se a relação com o Outro por quem se trata de ser amado, enquanto ele mesmo não é reconhecido como tal. Essa fantasia situa-se, então, em algum lugar da dimensão simbólica entre o pai e a mãe, entre os quais, aliás, ela efetivamente oscila (Lacan, 1957-58/1999, p. 256).

Lacan destaca que, embora o personagem que bate pertença à linhagem dos que detêm a autoridade, não há por que se nos contentar com uma homologia com o pai. A fantasia explicita que é o próprio sujeito que lança mão do pai como aquele que responde por sua entrada na sexualidade. Entrada que se dá pelo significante, o que permite não fazer coincidir aquele que detém o chicote com o pai. Em Lacan, o significante paterno está situado para além do pai, ele é "aquele que, no lugar do Outro, instaura e autoriza o jogo dos significantes". (Lacan, 1957$58 / 1999$, p.328). Se o agente é uma figura de autoridade, quem comanda a cena é o significante bater. 
O trauma ou a cena primária não é senão o significante enquanto pura diferença marcando o sujeito. Marca pura que articulada à fantasia, esse bate-se, é aqui o significante-pivô ou o significante da falta (falo). Assim não é o pai, mas o significante, o chicote, que promove a condição do sujeito dividido, isso significa que nesse lugar não há pai algum, sendo essa passagem que institui uma barra (falta) no Outro.

A fase terminal da fantasia "bate-se numa criança" é a matriz, o molde do comportamento do sujeito e indica assim a subjetivação de uma etapa primária na qual se dá a ligação das pulsões de vida e de morte e que algumas paradas na evolução do sujeito são atribuíveis ao isolamento precoce da pulsão de morte. Essa fantasia mantida para satisfação autoerótica, concebida como traço primário de perversão, é um elemento sexual fixado e isolado do resto da sexualidade infantil. Esse traço perverso da fantasia será mobilizado pelo alienador nas suas indicações de maus-tratos, abuso, negligência reforçando um gozo, pois todo sujeito por constituição goza da posição masoquística que incide sobre a fantasia originária.

A fantasia aparece como uma solução, pois ao mesmo tempo ela vela e revela, a condição de existência do sujeito. Mas, pode ganhar mais ou menos consistência, mais ou menos pré-história. Na SAP, a fantasia toma mais consistência a partir do reforço de seus elementos imaginários com o discurso de vitimização. A repetição dessa fala pelo alienador sobre - genitor alienador como aquele que "bate" toma consistência de realidade psíquica para criança confundindo os profissionais ao ouvir sua convicção, animosidade e sofrimento.

O objeto primordial falta e o sujeito vai homologar essa perda de objeto formulando a fantasia, o que faz dela um elemento universal e constitutivo de todo sujeito. Por isso a ética da psicanálise não opera através do par vítima-agressor. Embora reconheça o gozo no princípio da subjetividade, parte do princípio que pela posição de sujeito se é sempre responsável. 
Para Freud, as fantasias constituídas fundamentalmente pelo imaginário, mostram aspectos conscientes e inconscientes enquanto para Lacan a fantasia é uma estrutura formal de natureza inconsciente. Ela pode ser expressa através de uma fórmula $\$<>a$, que indica o modo de relação do sujeito (barrado) com seus objetos substitutos desse objeto privilegiado e originário que nunca pode ser igualado.

Assim, o fantasma é uma construção que aponta o modo singular através da qual cada um procura determinar um caminho em direção ao gozo, pois a "fantasia torna o prazer apropriado ao desejo" (Lacan,1963/1998,p.785). Assim a fantasia pode ser situada como uma frase com uma estrutura gramatical que sofre transformações, uma cena da qual o sujeito é espectador e é também uma forma de domar o gozo, transformando-o em prazer. Em síntese, a fantasia é uma estratégia destinada a propor o objeto para o gozo do Outro e sustentar o desejo.

A cena em que o sujeito ficou fixado e é o fundamento da posição subjetiva nas diferentes situações de vida. Por isso a SAP pode trazer importantes consequências se incidir sobre a constituição fantasmática na primeira infância. A fantasia é o modelo do seu estilo de comportamento e de economia de gozo, pois a resposta ao "Che vuoi" ( $O$ que queres de mim?) que se articula no nível do corpo, mais precisamente com as bordas do corpo. Mas à pergunta pelo valor que o sujeito tem para o desejo do Outro, o Outro só pode responder com significantes da demanda.

O significante da demanda vai dar lugar a uma gramática da pulsão - voz ativa, reflexiva e passiva (ver/ver-se/ser visto). No terceiro tempo da pulsão, nessa gramática do Outro, Lacan aponta que há o fechamento da pulsão, pois não se trata de pura passividade, mas de um sujeito que se dá a ver. Assim se fazer ser visto, ou se fazer maltratado, humilhado, abusado, negligenciado, seja qual o verbo que se use na conjugação, é o ponto de detenção do capricho do desejo do Outro que marca um gozo não ligado, fora da cadeia, que vai se repetir. 
O objeto, primeiro, que a criança propõe ao desejo parental, é sua própria perda: Pode ele me perder? "A fantasia de sua morte, de seu desaparecimento, é o primeiro objeto que o sujeito tem a por em jogo nessa dialética" (Lacan, 1964/1985, p.203), seu desaparecimento, a fantasia de sua morte é urdida pela criança em relação ao amor de seus pais.

O sujeito sustenta a crença de que o Outro sabe as trilhas do desejo, o Outro é consistente. A crença indica posse de uma verdade e está ao lado da religião e da alienação. Já a ciência está ao lado da separação. Frente à sujeição, a dependência do desejo do Outro, a alienação, refere-se aos traços de gozo, o gozo da consistência. A separação permitirá ao sujeito encontrar as vias do desejo, desde que a transferência opere mantendo a "distância possível entre o ponto em que o sujeito se vê amável, - e esse outro ponto em que o sujeito se vê causado como falta por a, e no qual vem arrolhar a hiância que constituía divisão inaugural do sujeito" (Lacan, 1964, 1985, p.255).

Lacan distingue o reconhecimento no plano do imaginário narcísico do reconhecimento no qual o sujeito se realiza como objeto a, ponto mais além da identificação, "mais além que se define pela relação e pela distância do objeto a minúsculo do I maiúsculo idealizante da identificação" (1964/1985, p.257) A identificação é um modo de relação do sujeito ao Outro, se dá desde o lugar do desejo, dos dizeres, do significante e dessa forma pode-se entender que a imagem oferecida pela criança busca se fazer notar, atrair o olhar do Outro. Olhar que antecipa toda ação ou posição da criança, olhar que foi instituinte do sujeito quando o localizou como o que viria a revestir, encobrir, colmar a hiância estrutural.

O sujeito em sua relação ao Outro, "realizando-se na fala, se institui no nível do sujeito suposto saber" (Lacan, 1964/1985, p.257), e essa transferência pode terminar numa identificação ou no mais além que separa a idealização da identificação. Lacan retoma a distinção freudiana entre hipnose e estado amoroso em suas formas mais extremadas a 
Verliebtheit, a fascinação amorosa e até coletiva. O estatuto da hipnose se dá na superposição, o mesmo lugar do objeto a e do Ideal de Eu, ao que Lacan acrescenta que o objeto a é idêntico ao olhar "... Freud aponta precisamente o nó da hipnose ao formular que o objeto é ali um elemento certamente difícil de apreender, mas incontestável, o olhar do hipnotizado" (Lacan, 1964/ 1985, p.257).

Lacan coloca que a operação da hipnose é oposta a operação analítica, isto é, frente à entrega enamorada irrestrita, que propõe o sujeito enamorado/hipnotizado, o analista separa o que se superpõe na hipnose e no enamoramento. O Ideal é o lugar desde onde o sujeito se considera visto como amável pelo Outro, por isso o sujeito busca saber o que o Outro espera dele, busca ler os traços que permitem que o Outro o ame, um espelhismo possibilitado pelo suporte simbólico, imaginário e real que emprestou o Outro primordial.

O sujeito em contato com o discurso do Outro primordial se encontra não só com sua palavra que possibilita a identificação, mas também com o enigma de seu desejo. A resposta que o sujeito oferece à falta que transmite o Outro, a seu desejo, é colocar ali um objeto do qual se desprende.

O Outro que possibilitou ao sujeito uma identificação antecipada com a imagem especular, assim como um lugar na cadeia de parentesco, um outro, que encarne o lugar do saber, que se veste com os traços que crê que o fizeram, é uma transferência, em que coincide o Ideal no lugar do objeto, condição da hipnose, que levara o sujeito a identificação com ele.

Esse Ideal do Outro quando ocupado pela figura de um pai ideal, é uma potência paterna que se supõe deter o falo, serve de escudo ao sujeito contra castração. Esse Outro idealizado faz Um à medida que o sujeito encontra aí a causa de sua identificação, podendo até fazer dele o nome de sua identidade, e lhe entregar sua autonomia. Isso quer dizer que esse Um do Ideal forma unidade à medida que os sujeitos encontram nesse Outro idealizado o traço unário de sua identidade. 
Freud aponta que na identificação o objeto é perdido, houve renúncia, o que faz com o objeto adquira o sentido do objeto perdido em cada reencontro com ele, contrariamente à hipnose e ao amor, em que há conservação do objeto. Se um substituto do pai vem no lugar do Ideal do Outro, há suposição de que detém o falo que falta aos outros, o que provoca a confusão entre o governante e o mestre do desejo. Isso explica o fascínio nesse lugar idealizado do Outro. Uma busca orientada dessa maneira pode se tornar monstruosa e submeter os sujeitos a uma paralisia do eu até a perda da razão. É nisso que se explica o efeito do olhar do hipnotizador, pois a hipnose é o mecanismo de captura/produção do sujeito e também o da formação de uma massa.

A transferência como aquilo que da pulsão afasta a demanda, separa o que na estrutura está unido: pulsão e demanda. Esta separação isola a demanda como um puro pedido ao Outro, como uma pura formulação, um puro pedido ao outro, pedido de reconhecimento imaginário, satisfação impossível que a demanda propõe - a pretensão de tornar completo o Outro; com isto desfaz o engano que a transferência propõe.

Por isso todo aquele que não abdica da idealização, que toma o lugar do Ideal para encarná-lo além de cristalizar o sujeito em posição submetida, perpetua o engano desse lugar do Ideal, predestinado a não querer saber nada acerca de qual é a razão pulsional da demanda, pois os efeitos de transferência sempre implicam o amor enquanto dimensão do engano. Nessa massa de dois, um par onde o outro encarna ao mesmo tempo o ideal e objeto constata-se que a criança permanece numa captura incestuosa, instituída como um rei que em sua impostura realiza a presença do objeto no fantasma sem a possibilidade de responder como sujeito com corpo próprio.

No texto "Duas notas sobre a criança" (1969/1998), Lacan acrescenta que a criança "quando realiza a presença do objeto a no fantasma aliena em todo processo o acesso possível da mãe a sua própria verdade, dando-Ihe corpo, existência e inclusive a exigência de ser 
protegido".(p.13) Nessa exigência, o giro compulsivo advindo em posição despótica, a criança se apresenta em um transe hipnótico por não haver nenhuma instância separadora, a transferência se torna hipnótica, não há intervalo entre S1 e S2, há uma soldadura devido à consistência máxima outorgada ao Outro, o que elimina o mal-entendido próprio do falante.

A transferência está presente em toda relação na qual alguém endereça sua fala a outrem supondo um saber. Essa estrutura se dá a partir do objeto parcial e seu envoltório - o ágalma, determina-se em uma relação ao desejo e em uma exigência de amor, dimensão do engano própria à posição de enamoramento do falante quando se dirige ao outro, dentro e fora da análise.

Quando um outro encarna o suposto saber, mola da transferência não colocando em jogo a falta se verifica um retorno à alienação imaginária ligada a um gozo primitivo e o que deveria ser a introjeção da palavra do Outro aqui se faz incorporação de um mandato. Aqui se constata no campo do simbólico o que Freud diferenciou no interior do Ideal de Eu como supereu, pois a incorporação dos mandatos parentais se deve ao efeito da assunção do vínculo incestuoso com estes objetos. 0 supereu toma sobre si o poder da instância parental, porém unilateralmente, representa a lei, mas em seus aspectos insensato. E com este esse artifício o sujeito mantém seu ideal de onipotência, recusando a divisão constitutiva do sujeito e calando toda crítica. Dessa forma a palavra do Outro funciona como sugestão e elimina a enunciação do sujeito.

As identificações sustentam modos de relação com o próximo que se jogam no campo do discurso, isto é: no laço social, o mal-estar será denunciado precisamente pelo que ocorre ao sujeito na sua relação com os outros. Não se trata aqui de retorno do recalcado, do sintoma ou inibição como sintoma, mas de uma adaptação ao Um idealizado.

Para Freud, o fanatismo, a hipnose ou o estado de enamoramento representam três casos nos quais o objeto exterior: o chefe, o hipnotizador ou o amado, vêm a ocupar o lugar do ideal do eu no mesmo 
ponto em que o sujeito projeta seu eu ideal. Para Lacan, o ideal de eu designa a instância da personalidade cuja função no plano simbólico é regular a estrutura imaginária do eu, as identificações e os conflitos que regem suas relações com seus semelhantes.

Mas Lacan indica que o Ideal de Eu recobre o que na estrutura constitui o olhar do líder e também sua voz, isto duas formas como o supereu se manifestam em seu estatuto real. O supereu aparece na obra de Freud, como uma instância relacionada com a consciência moral, com a proibição, com o sentimento de culpa e também como herdeiro do complexo de Édipo, introjeção da autoridade das figuras parentais, resultante dos desdobramentos da fase final do complexo de Édipo.

Mas há uma diferença entre o plano da demanda enquanto exigência absoluta feita ao Outro para manifestar-se aqui-e-agora e diante da qual o sujeito está numa posição de dependência absoluta em relação ao Outro, porque ele the favorece o poder de ouvi-lo bem ou não e a pulsão invocante na qual o sujeito não está mais na dependência da demanda, pois supõe uma alteridade na qual o sujeito poderá advir (Vives, 2009).

Portanto, além da demanda, da pulsão invocante tem-se que considerar a voz como supereu real. Trata-se de um fragmento de voz desatrelado de suas amarras simbólicas, o mais próximo do objeto errático denominado, na teoria lacaniana, objeto a. Essa voz cativante, que chama a criança e propõe-lhe gozar eternamente da indiferenciação, advém como um apelo incondicional que deixa sem voz aquele que a escuta. Essa voz veicula uma promessa de gozo, tal qual as sereias de Ulisses, remetendo o sujeito a um tempo anterior à Lei. Se a voz é aqui mortífera, é porque a relação à Lei é salutar ao desejo humano no que ela permite ao percurso desejante perdurar e não se perder.

Essa voz, enquanto tal, se oculta na significação no ato da palavra, aparece como uma injunção - Goze!, deixa o sujeito sem voz, afundandose em um silêncio. "Essa voz cativante, que chama a criança e propõe-Ihe gozar eternamente da indiferenciação, tem uma representação no mito das sereias.", (Vives, 2009, p. 191), naquilo que se escuta do imperativo 
supergoico. Nesse caso, o Eu encurralado pela pressão vocal supergoica, comete, contra si mesmo, atos que implicam sacrifício que podem chegar à morte, revelando o masoquismo que habita o núcleo do ser.

$\mathrm{Na}$ neurose, os mandatos de gozo do Supereu estão coordenados à Metáfora Paterna - significantizados: o Supereu como imperativo insensato se cola no lugar do fracasso da Lei, funcionando como causa de desejo e mantendo sua articulação com a demanda. Por sua incidência, o sujeito fica suspenso entre a demanda ao Outro e o objeto a, em que tem-se como possíveis respostas: apelação ao Outro no fantasma (negociando desejo e gozo), ou dejeção do mundo na ruptura do marco fantasmático.

A barreira desejo-lei que impõe limites ao gozo não é totalmente infranqueável, sempre acaba atravessando um resíduo que, enquanto causa (de desejo ou de gozo), vocifera na intimidade da subjetividade: resto de gozo no imperativo do supereu que circula como real graças ao simbólico. Por isso não basta indicar que o supereu é antagônico ao desejo, é preciso indicar ainda que ele é o seu avesso, revelando assim a patogenia da lei, sua falha estrutural, falha insanável devida ao real.

Algo que olha antes que haja alguém para ver, mas também tem-se que considerar a voz do hipnotizador aqui, que deixa o sujeito num mutismo e na reprodução das palavras sugeridas.

Assim a hipnose, o enamoramento, a religiosidade são nomes da crença, modos que privilegiam o gozo do sentido. E o suporte dessa operação é o amor ao par, ao hipnotizador, ao líder, nostalgia do pai da horda primitiva, de um Outro completo, um Outro consistente, crença no Outro incastrável. Isto é, a nostalgia pela encarnação desse pai Ideal, cuja autoridade, sempre arbitrária, aparece como obstáculo e contrapeso à transmissão da Lei.

A psicanálise aparece como operação que pode dissolver a sugestão existente em toda relação transferencial que faz recair em duas pessoas, três funções, pela colusão do objeto e ideal, reintroduzindo a terceiridade, ali onde o sujeito através de uma demanda de amor dirigida ao pai, uma 
demanda de amor do pai; como amar é querer ser amado, o sujeito se oferece então ao pai idealizado como amável. Isto porque a transferência é o fundamento da sugestão e não o inverso, a transferência constitui um poder que para alcançar seu verdadeiro valor de transferência, requer não ser usado.

Como no narcisismo só se ama a partir do que lhe falta, para realizar um ideal pode-se dizer que é por meio da idealização que se introduz a falta que instaura a possibilidade de amar, ou seja, não se ama se não é com o desejo, o amor é um efeito do desejo. $O$ amor sendo o que o eu busca no objeto para alcançar o ideal tem um componente simbólico. Por isso, o amor que se desloca metonimicamente de significante em significante, é a busca desse ideal.

O amor narcísico não permite ao sujeito um devir no mundo que não seja a partir da repetição ou do empobrecimento do eu, que passe de um amor-gozo a um amor-desejo. Por isso Lacan já situava, no seminário cinco, uma superposição, o que revela a ambiguidade que há entre transferência e sugestão. (Lacan, 1957-58, p. 439). Ele situa a sugestão na categoria da demanda de satisfação de uma necessidade: que "está ali, no nível da demanda, da demanda que o sujeito faz ao analista pelo simples fato de ele estar ali" (p. 440). Aqui, a sugestão - estando ela articulada ao que é da ordem do imaginário, do enamoramento, o que remete à universalidade do laço - é inevitável, e dela se faz uso, dela o sujeito se serve para que se estabeleça a transferência.

O desejo se situa entre as duas linhas - entre sugestão e transferência; entre a demanda de satisfação de uma necessidade e a demanda de amor - como o diferencial necessário para que elas não se confundam. É a partir desse diferencial que a psicanálise situa a condição para que se dê a transferência em sua especificidade psicanalítica, ou seja, é sobre a questão do desejo que repousa a concepção essencialmente psicanalítica da transferência, assim como o seu manejo. 


\section{5. (DES) ALIENANDO - UMA SEPARAÇÃO NECESSÁRIA}

\subsection{O VALOR DA SAP NA QUESTÃO DIAGNÓSTICA}

A psicanálise tem por base diagnóstica os processos psíquicos inconscientes e uma posição sintomática neles ancorada que refuta o estabelecimento de parâmetros de normalidade segundo características genéricas do ser humano. A adoção do modelo estrutural em detrimento de um modelo fenomenológico afasta a adoção da classificação dos fenômenos em função de modelos dados, isto é, a classificação nosográfica. Alguns sintomas da SAP em crianças que passam pelo litígio dos pais não implicam necessariamente o diagnóstico da Síndrome, assim há que se ter o devido cuidado para não simplificar e reduzir as possibilidades a partir da teoria da SAP. Segundo Sauber (2006), "pode ser o caso de que a SAP não exista ou que certos comportamentos não deveriam ser atribuídos ao genitor inocente acusado de programação. Em alguns casos, esses fatores são complicados de desemaranhar". (p.31)

É natural que a criança no curso de seu desenvolvimento defira sua decepção e negatividade em ambos os pais. Culpa-os por tudo aquilo que seus pais não Ihe dão, desde atenção, amor até coisas materiais. Por mais que se dê, nunca será suficiente. E não deveria mesmo ser. É dessa lacuna criada, da não adequação, a não adaptação, da insatisfação da criança com seus pais que surgem os projetos, as miradas... Deixando-se para trás a fixação nas figuras parentais. É esse o motor que permite a separação dos pais em direção a uma figura substituta e que promete em seu ideal dar-lhe aquilo que não foi the dado pelos pais. Parafraseando Strauss (2000):

Sempre temos algumas acusações a fazer aos pais que tivemos. Graças a Deus temos algumas acusações a lhes fazer, pois é o que nos dá chance - de acordo com o que Freud nos disse nesse artigo - de começarmos a nos libertar deles. É porque as coisas não se encaixam tão bem assim entre pais e filhos que terá início o processo de afastamento em relação à família (p.12). 
A crítica da criança aos pais, longe se representar uma alienação pode antes ser uma separação segundo a psicanálise. Há que se definir por exemplo, se os pais usam tais criticas de forma a alinhar a criança. Dessa forma, as críticas da criança endossadas pelo alienador podem representar mais uma alienação do que uma separação.

Em famílias que passam por conflitos na separação, o genitor pode fazer comentários negativos a respeito do outro genitor, entretanto, apesar de a criança responder com algum tipo de recusa ou animosidade em relação ao outro genitor, essa resposta não apresenta um formato de campanha. Sua resposta pode relacionar-se a dificuldades que existam entre ela e o outro genitor, o que no pós-divórcio provocará o alinhamento com o genitor. Por isso deve-se partir do principio de que o diagnóstico é diferente de uma etiqueta, ele deve indicar apenas um dos meios de orientar um tratamento ou intervenção. Fixar de antemão quais os mecanismos psíquicos utilizados na rejeição de filhos a seus pais desconsidera a especificidade de cada sujeito. Além disso, tal postura obtura a escuta das diferenças, o que restringe a possibilidade de intervenção, podendo levar a uma leitura equivocada e a intervenções que produzam danos secundários. Apesar do sentido classificatório e pasteurizado para o qual a abordagem de Gardner possa resvalar, o autor desmistifica:

...a SAP é uma entidade separada do abuso físico, emocional e sexual. Isso não significa que a SAP não coexista com abuso, um abuso pode causar a SAP ou ser adicionado a SAP... Isso não significa que a presença de um não afeta o outro... Isso também não significa que a presença de um pode não afetar o outro. Eu também mencionei a incorporação de uma falsa alegação de abuso sexual na Síndrome de Alienação Parental. Mesmo assim elas são entidades separadas e cada uma pode certamente existir sem a outra (1998, p. 114).

Tampouco o psiquiatra sugere que as intervenções sejam padronizadas e aplicadas a partir de respostas simplistas do tipo: tem SAP ou não tem SAP. Refere o autor que o profissional da área da saúde mental deve estar consciente e ser crítico a respeito da assertividade que o sistema demanda, não basta responder se é o caso de alienação ou não, pois seria uma resposta parcial, podendo levar a erros. Existem fatores 
mais complexos que necessitam ser esclarecidos e detalhados para que orientem o trabalho do magistrado, como, por exemplo, os fatores que originaram a SAP partir da criança e fatores externos. Então, se uma divisão injusta de bens disparou uma SAP, o especialista deve indicar tal fato. (Gardner, 1998, p.123)

Essa questão remete a um debate fundamental ao tema deste trabalho: que tipo de responsabilidade deve-se dar à criança alienada se, para a psicanálise, ela é um sujeito? Uma intervenção normalizadora no sentido de que a criança "deve sempre visitar o genitor alienado" pode representar uma posição repressora educativa. A recusa da criança pode ser genuína por representar seu desejo; em que medida deve ser forçada a tais visitas, se o genitor alienador continua demandando que ela recuse o outro genitor? Não seria um cabo de guerra com as crianças? Por isso, a função do juiz deve visar um corte do gozo no alienador para que ele libere a criança da necessidade de responder com a recusa ao outro genitor. Nos casos em que a criança não recusa completamente o outro genitor, a intervenção do juiz parece ser menos arriscada, pois a alienação se desfaz depois de pouco tempo junto ao genitor alienado. Trata-se portanto de diagnosticar - que recusa é essa? A que responde a criança? Para que se possa assim fazer uma intervenção que não provoque mais danos.

Houve o caso de uma criança de 10 anos em que a direção inicial do tratamento de forma equivocada não permitiu afrouxamento dos sintomas que a trouxeram ao atendimento. Partia-se do princípio de que "a mãe deve obrigá-lo a fazer as visitas ao pai". A criança começou a roubar os coleguinhas e dinheiro da mãe, xingar a genitora e seu marido, mentir deliberadamente, entre outras tantas transgressões. $O$ pai obcecado por retaliar a mãe e por não aceitar a separação, alinhava o filho ao seu lado através de chantagens, sevícias verbais, coerção, intimidação, imputação de culpa, assédios intensos (apesar de vê-lo apenas a cada 15 dias). A criança tinha medo do pai tirânico que diretamente dava comandos para ele retaliar a mãe e o padrasto. Dessa forma, desautorizava a mãe, 
deixando de transmitir à criança o respeito a si e ao outro, a lei social. Certo dia, a criança elaborou, em análise Não quero mais deixar de respeitar as pessoas da mesma forma como meu pai faz comigo; enquanto ele não entender que deve parar com isso prefiro não vê-lo, está me fazendo muito mal. Peço para ele parar mas ele não aceita, fica nervoso, grita e até dá soco na parede. Parece que eu sou o pai e ele o filho. A ratificação dessa decisão e posição pela analista foi o que permitiu a criança sair de uma posição rígida e gozosa, afrouxando o sofrimento e os sintomas.

A SAP, nos EUA, foi algumas vezes associada a junk science, (ciência sem base científica): os padrões de pesquisas científicas médicas não foram aplicados por Gardner em seu estudo para explicar a etiologia da patologia psiquiátrico-psicológica - a programação do alienador. A adoção de uma síndrome psiquiátrica ocorreu a partir de suas observações clínicas como perito terapeuta psiquiátrico. Jorge (1995) traz uma crítica a esse entendimento, refere 0 autor que a evolução dos métodos diagnósticos em psiquiatria passou por volta da década de 70 a dar muita ênfase aos fenômenos psicopatológicos objetivos e precisos em detrimento dos subjetivos, ou seja, da fala e da queixa do paciente."Van Praag ressalta que objetividade é a palavra-chave em psiquiatria hoje; o subjetivo tornou-se sinônimo de não operacionálizável, não-mensurável, não quantificável, não verificável, e até mesmo não científico" (Jorge, p.23). O autor desenvolve:

...uma ampla variedade de fenômenos psicológicos são ignorados pelos instrumentos de mensuração atualmente disponíveis, não sendo convenientemente utilizados para diagnosticar e classificar transtornos mentais... Não se deve confundir diagnósticos com doenças; satisfazer critérios exigidos para uma determinada categoria diagnóstica não é necessariamente o mesmo que padecer de uma doença psiquiátrica. (p.23)

No entanto, a categorização diagnóstica é usualmente expressa como se fosse uma doença, mas ela pode mais servir a uma leitura, a uma direção à intervenção ou ao tratamento. 
Portanto, as criticas quanto ao fato de a SAP não existir como categoria científica médica não anulam algumas observações e contribuições de seu estudo que possam ser utilizadas em avaliações, diagnósticos e no juízo das situações de litígio em favor de uma ética e política de convivência que regule ou impeça que a criança seja alocada como objeto de posse - objeto de gozo de um genitor na disputa pósdivorcio. Sua obra deve ser lida menos como um modelo classificatório e mais como um modelo de observações clínicas muito refinadas e ricas.

Em relação às críticas à possível pasteurização da problemática familiar na teoria da SAP, pode-se perceber que o mesmo ocorre em relação às teorias a respeito do abuso sexual infantil utilizadas para fundamentar as situações abusivas. Amendola (2009) traz essa importantíssima discussão em foco. No entanto, são inegáveis as contribuições dos estudos clássicos. Talvez a discussão deva centrar-se mais no treinamento clínico do especialista, visto que a mais importante ferramenta do profissional da saúde mental é a escuta da singularidade do caso, que pode sofrer um importante viés a partir de sua subjetividade, tornando o diagnóstico uma tarefa no modelo da cama de Procusto. Apesar das críticas, não se deve negar o marco de seus estudos na questão relativa aos falsos abusos, que leva a questionar as práticas e técnicas utilizadas pelos profissionais para avaliar tais alegações, pois, segundo Gardner refere, a criança pode confirmar um abuso que não ocorreu.

Sua teoria traz o acento das consequências da atuação profissional que pode desencadear uma SAP ou intensificá-la, seja um psicólogo que atesta um abuso quando não ocorreu ou o magistrado que não identifica corretamente a SAP deixando de coibi-la. Por isso as críticas não devem levar à generalização de que este tipo de abuso no pós-divórcio não existe.

Sua abordagem traz contribuições singulares sobre a investigação de linhas mestras no diagnóstico da rejeição da criança, sobre o diagnóstico diferencial das alegações de abuso e sobre dois tipos 
particulares de abuso psicológico e físico típicos nas situações de alta litigância.

A crítica da psicanálise à sistematização diagnóstica através da enumeração de sintomas feita pela psiquiatria não elimina o que existe de mais central na tese formulada por Gardner, no sentido de que se deve dar o acento correto à rejeição da criança, pois para além de ser uma resposta ao sintoma do casal parental (ou à dinâmica familiar segundo a Psicologia), existem as questões da parentalidade de cada genitor.

Em razão das críticas que o modelo sindrômico da SAP atraiu, os pós-gardnerianos optaram por criar novas abordagens que utilizam o termo alienação parental sem o uso termo médico Síndrome. Pellini (CRP, 2011) sugere que os psicólogos não utilizem o termo síndrome por não ser reconhecido na classificação médica no momento. Afirma a psicóloga que se trata:

...não do ato da alienação, mas dos distúrbios a que a criança ou o adolescente estariam sujeitos em consequência desse ato. Ou seja, independentemente de qualquer avaliação sobre a síndrome - motivo, por si só, de controvérsias -, os psicólogos do Judiciário podem ser solicitados a atestar uma doença que não está classificada até o momento. (p.24)

O profissional, no entanto, deve precisar e fundamentar qualquer termo que utilizar, pois são muitas as correntes e teorias que falam de alienação parental.

Tais polêmicas não devem levar o psicólogo a deixar de identificar e descrever o abuso psicológico independentemente de existir um nome específico. É um dever ético fornecer esclarecimentos detalhados para uma retaguarda legal quando há necessidade de proteção da criança. Ocorre que o operador, muitas vezes anestesiado pela gravidade cotidiana no entorno de seu trabalho, deixa de ressaltar aspectos na avaliação necessários à proteção da criança. Ele se esquece de que, para além dos efeitos práticos que um documento pode ensejar, seu conteúdo surte efeitos subjetivos nas partes e pode ajudar na regulação do abuso infantil. 


\subsection{PSICANÁLISE E SAP}

Na Síndrome de Alienação Parental descrita por Gardner constata-se uma montagem feita por um cuidador que exclui um dos genitores da função de transmissão e do lugar do Outro da criança/adolescente, oferecendo a ficção do Outro completo (não marcado pela falta que institui a diferença sexual). Isso pode causar consideráveis danos ao sujeito, no seu porvir como sujeito sexuado e na assunção de uma maternidade/paternidade, levando o sujeito ao pior - ser devastado por um gozo sem freio que aniquila sua singularidade: a posição desejante.

Na SAP, a autoridade do genitor alienado não é legitimada pelo programador. A exclusão do primeiro faz-se via uma desautorização de sua função, impedindo as condições para transmissão do respeito e para a autonomia pela criança. As consequências muitas vezes atingem a formação de futuras famílias pelos filhos envolvidos.

O que Gardner indica na SAP é a presença do sintoma da criança como resposta ao sintomático do casal parental, mas que se apresenta muito rígido, fixo ao gozo do genitor alienador. Embora a criança não revele conflito nem contradições na ordem discursiva, essa forma sintomática é devastadora porque presa ao supereu do genitor alienador, que impele o filho, através do imperativo de gozo, a partilhar desse modo de fruição gozosa, ainda que isto aniquile sua singularidade - a posição sintomática e desejante.

Lacan em "Complexos Familiares na Formação do Indivíduo" (1993/1938) apontou o declínio social da imago paterna como consequência do desenvolvimento do discurso da ciência. Ele fala de um declínio social da imago paterna e não declínio do pai, pois o pai em psicanálise é uma função, opera como pai simbólico, pois introduz a lei do desejo. Também deve-se aclarar que apesar da problemática indicada aí (devido ao declínio da imago paterna) no seio da família, apesar da crise familiar advinda, o mal-estar na família sempre existiu, mas deve-se situar o fato de que o aparecimento crescente de instituições que 
protegem e salvaguardam o bem-estar da família indica mudanças ou deslizamentos, inclusive uma redefinição da função paterna segundo o momento histórico-cultural.

Julien (2000) aponta que cada momento histórico redefine a função do pai e, nesse sentido, cada mudança traz com ela um declínio da mesma, qualificando-a de declínio social da imago paterna. Uma dessas mudanças, ele a situa no século XIX com o aparecimento dos direitos da criança, pois seguindo o discurso desses direitos pode-se constatar como os experts (psicólogos, pedagogos, médicos, etc.) intervêm como terceiro social na relação pai-filhos. Devido a isso, a parentalidade passa a ser definida antes civicamente do que biologicamente, enquanto se Ihe dá um estatuto legal.

Ao situar a queda do saber do mestre transformada pelo saber científico e responsabilizá-la pelo mal-estar das sociedades atuais, Lacan coloca em xeque o modelo do Édipo estrutural da psicanálise, mas ressalta que onde o pai se demite, o objeto é convocado, onde a palavra se eclipsa, a pulsão domina, apontando que a queda para o lado do supereuarcaico leva ao pior. Ele critica e ao mesmo tempo indica ser necessária a refundação da psicanálise sobre a questão do pai, pois o pai da realidade é distinto do pai ligado à lei do desejo e da palavra essencial na constituição subjetiva.

A modernidade privilegia os discursos científicos, e os investigadores encarregam-se de estabelecer os limites. Se os pedagogos, médicos, psicólogos indicam aos pais que leis transmitir às gerações seguintes, colocam-se, então, numa função particular - como se fossem os pais. A partir dessa lógica, percebe-se que a criação de vários dispositivos sociais para ensinar/aconselhar pais a educar e amar os filhos parte desse ponto da degradação da imagem paterna para criar "escolas para pais", suprindo uma deficiência que o social se atribuirá como responsabilidade, recurso também imaginário, pois como ensinar alguém a ser pai se não for pelo desejo? 
Além da degradação da imagem paterna, percebem-se mudanças nos ideais, no ponto onde o Ideal funcionava como um ponto de referência, como uma referência em torno da qual as pessoas se agrupavam. Devido os avanços tecnológicos, o acesso e utilização da Internet substituiu o agrupamento de massas em um espaço físico pelo virtual, levando a mudanças subjetivas. Isto tem como efeito que, de uma referência paterna única, agora se tem referentes diversos e assim a semelhança em torno de um referente como era Deus, passou a outro plano, ao plano do narcisismo e da individualidade. Os estados foram derrubados pelas leis do mercado. Agora é o pensamento científico que dá a salvação das pessoas, não mais Deus, e os discursos regularizadores das ciências - como a Psicologia, a Pedagogia e a Medicina - indicam aos pais a maneira de serem pais. Assim os direitos da criança e sua estreita regulação com o controle público da parentalidade indicam esse declínio, pois funcionam no lugar da verdade e da proibição religiosa.

Ao cair o estado da crença, caiu também 0 ato de fé e, consequentemente, os Ideais, os sujeitos só agindo em nome do bem-próprio, cessando o compromisso com a coletividade. O que caiu na modernidade é o pai como totem, mas não a palavra em si: o que caiu é a função de semblante do pai, mas isto não implica que os pais sejam desnecessários na orientação da criança/adolescente em direção ao seu desejo. O amor materno ou paterno não basta para estabelecer um porvir para o filho, o amor necessita da Lei - a lei do desejo que freia o gozo da posse. Só assim pode-se dizer que a família cumpre seu papel como suporte para o filho em sua realização como homem, sendo esse espaço onde a criança não pode ser tomada como objeto de um gozo sem limite de um genitor ou de um cuidador que a impede de situar-se em relação ao próprio gozo. O ponto mais importante na clínica de Gardner é demonstrar na práxis a presença desse gozo desenfreado que os discursos e semblantes encobrem e que pode ser justificado pelos experts a partir de um discurso científico. Por mais paradoxal que seja, Gardner, na sua 
tentativa de sistematização de um fato clínico, apoiando-se em vários discursos, afasta-se da ciência e aproxima-se da psicanálise. Assim seu ponto fraco - a formalização teórica não aceita pela ciência - mostra-se o ponto forte, pois, como Lacan apontou em Freud, que descobriu na fina clínica de Charcot, "la théorie, c'est bon, mais ça n'empêche pas d'exister".

A família não pode ser o lugar do enfrentamento de gozos irreconciliáveis dos pais/cuidadores, sem uma palavra que venha mediar e, por isso, as autoridades são chamadas a intervir cada vez mais para extrair os filhos dos infernos familiares. Dunker (2008) ressalta os efeitos deletérios de conflitos mal tratados entre os pais através da desautorização explícita de um (ou dos dois) pais. O psicanalista refere que a gravidade desse impasse "é tão pior quanto menor for a criança e mais agudo entre três e cinco anos quando a criança está fazendo uma passagem crucial pela qual se transfere o respeito à lei familiar para o respeito à lei social". . No entanto, não se trata de que o Outro social/assistencial venha substituir o Outro familiar. Neste ponto reside a questão ética da intervenção psicanalítica no campo jurídico, em que a disputa dos filhos é acompanhada da Síndrome de Alienação Parental. De acordo com Brandão (2009):

... a justiça tem a função de lembrar e fazer re-aprender o interdito, estando ela ligada então ao processo civilizatório. Pode-se dizer que a decisão de um juiz pode engendrar uma função terapêutica, pois organiza o sujeito de acordo com a referência legal por meio do qual se constitui o sujeito humano e ser vivente. Onde ocorrem os impasses da racionalidade genealógica advém a figura do juiz como aquele que está no lugar de autorizado de marcar o sujeito com a castração.

Lacan afirma que o Direito não desconhece o gozo, ao contrário, ocupa-se dele, tratando de reparti-lo, buscando encontrar a justa medida. No Seminário 20 "Mais ainda" (1972-73/1982), aponta que a relação entre o direito e o gozo é o usufruto. "O usufruto quer dizer que podemos gozar de nossos meios, mas que não devemos enxovalhá-los" (p. 11). Usufruto é então aquilo do qual se pode gozar, mas sem usá-lo em demasia. Lacan diz que o gozo é fruição, não é a busca de prazer que segundo Freud seria a 
finalidade do aparelho psíquico, prazer como descarga; o gozo é, ao contrário, tensão. O gozo teria, então, situado seu campo no mais-além, o princípio do prazer sendo uma barreira necessária ao gozo, que uma vez alcançado equivaleria à morte, ou seja, à destruição absoluta. É a esse gozo que o supereu visa, na medida em que ignora o limite inscrito na própria linguagem para a completude. Isso só seria obtido através de um forçamento que ameaça romper a própria estrutura de linguagem que faz existir o sujeito barrado. Por isso, essa satisfação liga-se necessariamente à morte, abolição do sujeito desejante no encontro com o indizível do gozo.

Constata-se na contemporaneidade um uso do gozo em demasia pelo apelo do discurso capitalista e da queda da imago paterna configurando uma face do gozo - a do supereu arcaico, mortífero devido à sua articulação com a pulsão de morte. Ao tratar do direito ao gozo, o jurista não dá conta do dever ao gozo, que aparece na figura do supereu configurando o gozo superegoico, pois este impõe limites até à clínica quando baseada no nome do pai (ou pai simbólico), uma clínica fundada no simbólico, que não leva em devida conta a satisfação pulsional.

Se o simbólico pode promover alguma organização e mediação para o sujeito e seu desejo, tem-se que considerar que a lei paterna falha em conter o gozo: o que Freud apontou em "Mal-estar na civilização" (193029/1996) ao falar do resto pulsional que nunca é capturado pela civilização e que tampouco desaparece pela ação do supereu, mas, ao contrário, aloja-se nele. A lei não domina tudo; não porque precisa ser melhorada, mas porque o resíduo pulsional não é de fato apreensível por uma lei geral.

Quando o operador do Direito se nutre da crença numa estrutura normativa com capacidade para distribuir a satisfação no espaço público, ou seja, a função de regular o que diz respeito ao gozo, através de sua indexação às normas, em sua montagem significante, ele deixa de lado essa face cruel do gozo que não tem mais sua regulação pelo recurso da identificação ao pai, ao Direito e às tradições e que necessita de uma nova política para o gozo. Pois há inúmeras novas formas de gozar que as ficções jurídicas não conseguem abranger através das normas, em particular no que 
tange à relação dentro da família, no seio da qual existe gozo que é preciso também frear para que não se aniquilem as singularidades.

Deve-se partir do princípio de que não há filhos colados a seus pais, se o pai faz o filho, o filho também faz o pai. Não se trata de se a família vai bem ou não vai bem, mas sim o que não vai bem, em cada família concreta, isto é: onde há um aprisionamento do filho num gozo anômalo e mortífero que o impedirá de seguir seu curso na separação do Outro parental. Dessa forma, para a Psicanálise a ênfase da teoria gardneriana pode ser levada muito a sério, pois não há que se ter uma situação concreta, como a alienação na SAP para que se verifiquem conseqüências devastadoras. A falta de ambivalência das figuras parentais, um dos sintomas apresentados pela criança com SAP, impede os processos de individualização, de autonomia, de separação em relação ao Outro. Strauss (2000), na apresentação de um caso clínico de análise infantil, aponta brilhantemente os desdobramentos mortíferos para a criança quando alocada como objeto de posse de um genitor:

...uma criança cujos pais não se separaram, já que nunca estiveram juntos, e que nunca conheceu seu pai, pois foi fruto de uma união extremamente rápida entre sua mãe e o genitor. O pai desapareceu rapidamente, a mãe ficou grávida, teve a criança, casou-se em seguida e tem outros filhos. Este, portanto, é filho de um pai que nunca conheceu...Enquanto conversávamos, ele dizia coisas muito banais, até que confidenciou o jogo que costumava fazer com sua mãe: "o jogo das palavras proibidas". Ele então explicou o seguinte: de tempos em tempos, ele perguntava: "mamãe posso jogar o jogo das palavras proibidas? Mamãe me diz que sim e aí tenho o direito de dizer palavrões e de xingar meu pai... um babaca, um porcalhão... Isso faz a gente rir muito, mamãe e eu". A própria mãe enchia os ouvidos de seu filho com insultos dirigidos ao "porcalhão que transara com ela e acabara com sua paz". Jogo engraçado, porém, devo dizer, não me fez rir, antes me deixou chateado. De modo que retorqui: "Sem este babaca, este porcalhão, você não estaria aqui falando comigo, nem mesmo estaria vivo". Isso o fez parar, ele me olhou surpreso e, em seguida, me confidenciou o que "enchia sua cabeça o tempo inteiro", tanto na escola, como em casa, e que ele nunca dissera a ninguém: as idéias suicidas. Ele só pensava em se matar, mas era incapaz. Isso o obcecava de tal maneira, que não podia pensar em mais nada. É uma história surpreendente que demonstra como nos casos em que a mãe, tal como essa, deprecia o desejo, se recusa a assumi-lo, rejeita o que esteve em jogo no consentimento, mesmo que tenha sido o consentimento de uma noite apenas, há como conseqüência a impossibilidade da criança justificar sua existência. Para nós, seres humanos, a existência ... necessita de uma justificação no nível do desejo, justificação esta que se tornara especialmente impotente para esse garoto em conseqüência da rejeição que sua mãe fazia do que estivera em jogo em seu desejo (p.20). 
Julien, no livro "Abandonarás Teu Pai e Tua Mãe" (2000), afirma que a família é um dos nomes do Outro, o Outro, essa alteridade primordial, que é o lugar onde se constitui o sujeito. O sujeito, não sendo causa de si mesmo, necessita da presença do Outro incompleto e inconsistente, que demonstre sua inexistência, o que só se dará se em seu núcleo houver um casal sexuado, que permite situar uma história que diferencie parentalidade e conjugalidade. Isto é, é um dever ético transmitir algo no âmbito familiar que permita a um sujeito não ir ao pior, ficar preso nas malhas gozosas de um cuidador.

Na SAP, quando rompido o pacto da conjugalidade, inicia-se uma luta de prestígio pelo amor e fidelidade do filho visando a eliminação do outro genitor da função do Outro do desejo. Para obter estes intuitos, o genitor alienador faz um tipo específico de desautorização permissiva em relação ao outro genitor. A criança responde fazendo um levante contra o genitor alienado "...esta desautorização está simplesmente à serviço da fixação do pai como uma imagem amável, em detrimento da imagem odiosa que restaria..." (Dunker, 2008) ao outro genitor. Outra forma de desautorização comum na SAP é a inclusão da criança no processo de decisões e conflitos relativos aos pais, apagando as fronteiras (de assimetria e potencialmente coercitivas) que comportam os laços parentofiliais responsáveis pela transmissão do respeito e da lei social (Dunker, 2008).

O genitor alienador encarna o Outro da demanda absoluta e utiliza o amor para encobrir o seu gozo, fazendo uma fixação de figura amável). Por esta razão, um cuidador também pode vir a operar a alienação visando excluir um genitor dos processos de subjetivação da criança. Ao se abordar o conceito de alienação na teoria lacaniana, processo fundamental presente na constituição de todo e qualquer sujeito, permitese entender porque a programação sistemática do alienador obtém sucesso em produzir a SAP na criança.

A predominância do discurso sobre o amor que reina no campo dos direitos da criança e da família, situando a mãe como signo de amor, o 
amor como instintual e os cuidados maternais como algo natural, apresenta uma questão ética. Assim como na parábola bíblica sobre Salomão, que não se deixa enganar por um discurso, o operador do Direito tem o dever de distinguir o discurso da posição subjetiva do falante, seja ele qual for. A psicanálise não aceita nenhum status natural ou essência humana que seja ponto de partida para análise da condição humana. Frequentemente, o discurso sobre o bem, a virtude e a oblatividade, associado a um comportamento adequado, encobre um amor mortífero, pois aniquila o desejo ao rejeitar a alteridade, encobrindo o gozo da posse. Por esse motivo, a decisão do magistrado pode funcionar tal como a espada de Salomão, ao revelar a verdade das posições subjetivas dos envolvidos na disputa de guarda, indicando qual adulto permite o acesso à verdade da criança - abertura ao desejo.

O que pode ser extraído a partir da formulação da SAP como um tipo de transferência entre alienador e criança? Ela permite diferenciar a alienação como demanda imperiosa de um genitor dirigida a um filho que passa a recusar o genitor de uma alienação que pode ser oriunda de outras problemáticas. Ela torna possível desembaraçar situações familiares e nuanças importantes ao diagnóstico e intervenção. Brandão (2009) descreve uma situação no pós-divórcio muito próxima ao que Gardner cunhou por fenômeno de independência na SAP. O autor refere que a suposta autonomia da criança na situação de divórcio mascara a manipulação dos pais, tornando os filhos reféns daquele mais forte:

...os guardiões, que dizem de modo geral: 'não faço nada para impedir meu filho de ver o pai (ou a mãe); é a vontade dele que prevalece e, se o outro esbarra nessa dificuldade, é algo a ser combinado entre os dois'.

Muitos desses pais desconhecem que impor limites ao filho é, como diz Kehl (2003), num contexto semelhante de discussão, 'um ato performativo de linguagem que não precisa se sustentar com base em chantagens e ameaças'

É usual que, depois da separação, os filhos, por estarem vulneráveis e conflituosos, resistam a deslocar-se entre as casas dos genitores, necessitando que os adultos reforcem o dever parental das crianças para com o outro genitor e até imponham autoridade. Frequentemente esses 
momentos de resistência das crianças, chamados na Psicologia jurídica de conflitos de lealdade, são utilizados pelo genitor alienador em prol de seus interesses retaliativos, como forma de desvalorizar a outra figura, fazer a criança passar a recusá-la e encobrir seus intuitos alienadores. Essas situações muitas vezes se equiparam à programação mais sutil e encoberta, que deve ser diferenciada da dificuldade de um genitor em impor limites ao filho nesses períodos delicados. Apenas a leitura da posição subjetiva dos genitores junto à da criança permitirá diferenciar o fenômeno observado.

A leitura psicanalítica da SAP permite desimaginarizar o discurso do amor parental ao sublinhar os efeitos da alocação do filho como objeto de gozo de um dos genitores, a partir de um discurso de amor que justifica proteção, cuidados, adequação, mas que encobre o afastamento do outro genitor do lugar de transmissão simbólica para a criança, trazendo efeitos prejudiciais à criança, ao dificultar o curso de separação do grande Outro. A pergunta de Salomão - quem restitui à criança seu lugar de sujeito? Os efeitos da SAP aqui trazidos colocam uma dimensão além da que foi dada, isto é, a exclusão concreta ou perda do laço afetivo parental, os efeitos subjetivos de um reforçamento da alienação na subjetividade da criança. Evidentemente que muitas vezes a parábola de Salomão, em casos de intensos litígios de família, pode não oferecer uma direção a saída, mas, ao contrário, pode deixar muitas perguntas, lacunas, vazios e levantar mais dilemas do que apontar uma posição clara ao profissional: "Assim como é verdade, na maioria dos conflitos de divórcio, não existe uma boa ou má solução. Pelo contrário, tem-se que decidir pelo que consideramos a opção menos prejudicial de todas as opções disponíveis." (Gardner, p.337).

Embora o afeto nas relações seja reconhecido pelo Direito como um novo norte, não pode ser confundido com adequação no âmbito da parentalidade, quando das determinações judiciais. Lacan faz um jogo com a palavra "senti ment" que em francês é composto por dois verbos sentir e mentir, indicando que sentimentos não são índices de verdade, o 
que viria a apontar em casos de SAP que o explícito amor entre a criança e o programador e as dificuldades na relação entre alienado e os filhos não podem ser tomados como extração da verdade do sujeito. A ferramenta de Gardner permite enfatizar que uma recusa ao genitor deve ser tomada como um enunciado. A vontade, o querer, a fala devem ser escutados quanto a enunciação, pois o enunciado não representa um valor absoluto, não revela a verdade e não aponta a direção do desejo do sujeito. A enunciação corresponde a um ato, a intencionalidade do ponto de vista do sujeito redutor da fala, lugar desde onde se produzem os enunciados. A cumplicidade e o jogo entre a criança e o alienador podem levar ao engano imaginário dos operadores, desviando da questão princeps que deveria balizar as determinações: o verdadeiro amor é aquele que não retém.

O amor encobre a posição do alienador quanto à posse da criança como objeto de gozo, não permitindo restituir seu lugar de sujeito e criando um engodo de amor no qual constantemente caem os operadores. Lacan concebe o amor como simbólico - dar o que não se tem, configurando o objeto como um dom, isto é, no amor o amante doa a sua falta, jamais o amado é tomado como objeto de posse, como se pode ver no amor romântico que restitui o lugar de sujeito para o amado. Isto se comprova na parábola da Bíblia, pois no seu julgamento Salomão parte do conceito de amor como doação de falta para decidir qual é a mãe do bebê disputado. Ele escolhe a mãe que no enunciado diz que não é seu filho, pois na enunciação, em sua posição subjetiva, ela doa sua falta: a vida do filho que não the pertence. Enquanto a outra mulher, que insiste ser seu o filho mesmo que à custa de sua morte, revela em sua posição subjetiva o filho como objeto de posse.

A pura valência afetiva dos filhos em relação aos genitores, muitas vezes ressaltadas nos estudo psicológicos periciais, deve ser relativizada quanto à importância dada na avaliação. A teoria da SAP permite o questionamento quanto aos critérios que vêm sendo adotados nas tomadas de decisões, pois a criança dificilmente resistirá a um alienador 
que faz uma oferta de amor narcísico e imaginário para capturá-la, levando o espectador a um engodo, por não levar em conta a dimensão do gozo inconsciente escondida no discurso e no comportamento. Principalmente quando o alienador encarna o S1 da criança, a põe a gozar. Esse comando de gozo silencioso na SAP e que não se mostra como um discurso comum, leva à ruptura do laço social. Para Dunker (2008):

...o respeito, por ser efeito do valor simbólico da palavra, é algo que se transfere, ou seja, que passa de quem o tem para quem a ele se associa. Daí que ele seja um "ato reflexivo", ou seja, quem demonstra e pratica respeito, (pelo que nós reconhecemos como simbolicamente respeitável), adquire imediatamente nosso respeito. Inversamente, se alguém tem o nosso respeito tendemos a respeitar 0 que esta pessoa respeita

Completa Dunker que o respeito de um pai para com o outro é essencial pois ensina como ele é transferível, ele passa de pessoa para pessoa. Nesse sentido, a questão da alienação parental reveste-se de consequências aumentadas.

A ruptura do laço da criança com o genitor se dá devido a uma regressão da identificação à demanda. A intervenção do juiz pode voltar a instituir o Outro, terceira instância mediadora no campo da fala, e "reinscrever" a história de duas linhagens.

\subsection{A SAP COMO SUBPRODUTO DA CULTURA}

\subsubsection{Alienação no sistema judiciário}

A teorização sobre os efeitos da palavra na subjetividade, a partir da psicanálise, permite tanto compreender os efeitos da SAP na criança, como também entender a SAP como subproduto da atuação profissional de vários campos científicos, das práticas e leis jurídicas, do circulo social, portanto produto da cultura.

Sendo a fala o que funda o sujeito, a palavra terá um poder de libertá-lo da tirania do gozo. O dizer pertence ao eixo simbólico, no qual a 
análise opera, enquanto o gozo pertence ao eixo imaginário, registro do narcisismo, onde se desenrolam as miragens, que capturam o sujeito. Assim, é no eixo simbólico que se encontra a verdade do sujeito, porque o que funda o sujeito é a palavra. É pela palavra que se configura a historicidade do sujeito, que se dá o reconhecimento do desejo, que se abole o recalque, que se decifra o sintoma e que se ilumina a verdade do ser do sujeito.

A psicanálise privilegia o uso da palavra e considera que a linguagem estrutura o humano, organiza seu corpo, seu desejo e seu laço com o outro. Ou seja, é a ação significante que institui o humano na ordem cultural e que responde pelo advento de um sujeito falante ao se alienar na linguagem - a estrutura simbólica que responde pelo pacto civilizador.

Não é porque a psicanálise preconiza que o destino do sujeito é a alienação operada pelo Outro considerado como linguagem que isso implica que não se possam considerar os efeitos na subjetividade de uma atuação profissional, pois esta também implica uma fala e portanto um quem fala, o que se fala, e desde onde se fala. Há que se considerar os efeitos a partir do lugar de poder e de dissimetria dos profissionais, principalmente aqueles que representam a instância da lei, pois isso acentua o poder de suas palavras.

A este respeito, Brandão (2009) ressalta os efeitos na subjetividade no contexto da família a partir das práticas jurídicas e das leis que regulam o socius:

Se o texto das leis deixa margem a interpretações que resultam na desvalorização das figuras representativas da autoridade, elas produzem em seu conjunto efeitos imaginários que se observam, tal como afirma Hurstel (1999) à luz da psicanálise, nas representações coletivas, nas práticas e nos modelos normativos de pai, dos quais emerge a figura do "pai carente".

Num certo sentido, pode-se supor que a teoria da SAP de Gardner enfatiza na modernidade a importância da retomada do dever parental dos filhos para com os pais, ao descortinar que a recusa da criança, um engodo promovido pela expressão de uma vontade que se diz autônoma, 
viria a desautorizar o reconhecimento do (degradar o) lugar do Outro, que representa o interdito, a alteridade, o desejo, a Lei. O reconhecimento, pelo Judiciário, do genitor alienado como partícipe na vida da criança, permite convocá-la a responder de outra forma que não exclusivamente como objeto de recuperação de gozo para o genitor alienador que busca elidir a falta devido ao confronto com a falta que surge no pós-divórcio. Também vem a chamar esse genitor ao reconhecimento do outro e da falta desde onde se permitiu um encontro desejante de duas pessoas, onde se marca o lugar de origem da criança.

É preciso ainda ressaltar que, se por um lado a palavra do operador/juiz pode ter como consequência a alienação, por outro possui também efeito de restituir o lugar da lei simbólica, freando os gozos. Gardner não apenas cunhou o termo SAP, mas juntamente com sua teoria criou uma ferramenta para balizar a conduta profissional em casos que considera complexos. O autor enfatiza os erros mais comuns a que são levados os profissionais e as consequências da atuação dos operadores. Pode-se dessa forma enfatizar a participação do profissional na perpetuação da violência infantil ou familiar - uma palavra fora de lugar do promotor, uma decisão interlocutória e equivocada do magistrado, um relatório psicológico precipitado, o endosso pelo advogado de uma tese distorcida, a recusa da escola em se posicionar...

Em famílias que passam por conflitos de alta litigância, a iminência dos actings outs e passagem ao ato ${ }^{15}$ faz a atuação profissional revestir-se

\footnotetext{
${ }^{15}$ Apesar de estes dois termos serem tomados como equivalentes na psiquiatria e em algumas correntes de psicanálise como certas "formas impulsivas do agir." (Salvain, 1996, p.55), observa-se um esforço de precisão de Lacan. Na psiquiatria define-se como uma "violência ou a brusquidão de diversas condutas que curto-cirquitam a vida mental e precipitam o sujeito numa ação: agressão, suicídio, comportamento perverso, delito, etc" (Salvain, 1996, p.55). Lacan os relaciona à compulsão a repetição, condição do inconsciente mas frisa que existem diferentes tipos de repetição. Há uma repetição natural e insuperável por ser constitutiva do sujeito. Mas no acting out, o sujeito age no lugar de uma elaboração psíquica dos conflitos, no lugar de passá-los a palavra, ao simbólico retornando na forma de ato, ação. Lacan considera uma hierarquia entre o acting out e a passagem ao ato, sendo esta última mais radical. Considera-o uma atuação do desejo do Outro, uma expulsão do sujeito por ser destinada a evitar a angústia levando a um ato de ruptura integral do sujeito e uma condição de alienação radical, por exemplo, as saídas da angústia via suicídio.
} 
de uma importância e responsabilidade aumentadas Observam-se efeitos subjetivos iatrogênicos nos envolvidos a partir da atuação profissional pouco criteriosa - rupturas de relações, por vezes irreversíveis, estigmatização de pessoas, danos secundários.

O fator tempo pode ser apontado como um dos mais importantes elementos que influenciam no trabalho dos operadores. O sabido afogamento do sistema judiciário leva não apenas à demora no atendimento às famílias, mas gera um leque de efeitos na forma de o profissional realizar seu trabalho.

A exiguidade do tempo para o profissional despender com 0 atendimento de cada família inviabiliza a necessária atuação cuidadosa e singular. Prazos apertados, o ritmo mecânico e as demandas forçosas dificultam/impedem que o profissional adote uma postura reflexiva e crítica a respeito de seu trabalho, bem como sobre os efeitos do mesmo. Estratégias são lançadas para contornar o problema: decisões padronizadas, generalizações e adaptações aparecem como solução em face da situação de pressão para simplificar a conduta e reduzir o tempo gasto no trabalho, porém não sem prejuízo das partes. Em razão das consequências que ensejam as condições de trabalho dos profissionais que atuam no Judiciário, não se pode justificar uma recusa à reforma nas práticas, por poder agravar o excesso da demanda, conforme critica Pellini (CRP, 2011) ao tratar sobre a nova Lei 12.318/2010: "Os concursos públicos nesse segmento têm sido poucos e menos ainda as nomeações. Não há psicólogos e outros profissionais contratados em quantidades suficientes para atender a demanda" (p.24)

Dentre as generalizações na atuação profissional, a banalidade na concessão das suspensões de visitas, diante de qualquer alegação, evidencia como ainda se ignoram os efeitos subjetivos das determinações judiciais. Nos quadros de SAP ou de programação, nota-se quão frequente se tornam os diversos tipos de falsas alegações dentro de um mesmo processo. Essas acusações vão desde maus-tratos e negligência até violência física, psicológica e sexual. Muitas vezes, o magistrado decide 
cautelarmente/liminarmente com base em provas unilaterais, como Boletins de Ocorrência e laudos psicológicos emitidos sem entrevista com a parte acusada. Segundo Cruz (2010):

O Superior Tribunal de Justiça, de forma uníssona, assim decidiu: 'O boletim de ocorrência não constitui prova dos fatos nele relatados, mas somente declaração unilateral'. Portanto, boletim de ocorrência, denúncia ao conselho tutelar e ao Ministério Público devem ser apreciadas com reserva, pelo Juízo de Família.

Com a justificativa de uma proteção dos direitos da criança muitas vezes precipitada, as provas unilaterais trazidas pelo genitor alienador adquirirem de antemão um valor de verdade que passa a surtir efeitos nas partes e repercute na própria atuação profissional.

Esse tipo de atuação profissional cumpre com um excesso de zelo por parte do magistrado e do Ministério Público, que, no entanto, se encontra muitas vezes dissociado dos efeitos de sua atuação, pela alta carga de trabalho que impede um exame mais criterioso. 0 juiz, temeroso de prejudicar a criança, prefere afastá-la de suposto risco, acreditando que a precaução é a menor das sequelas. Dessa forma, não se consideram as implicações nos envolvidos, devido a uma atuação que não leva igualmente em consideração a possibilidade de uma falsa alegação. A teoria de Gardner vem enfatizar os efeitos dessa face esquecida.

Constata-se também que muitas vezes o Judiciário toca pouco profundamente na análise de inúmeras acusações quando estas se apresentam à primeira vista infundadas. As falsas denúncias, quando comprovadas que foram fabricadas, raramente surtem efeitos coercitivos em quem acusa ou efeitos protetivos na criança, deixando assim de regular a conduta abusiva de um cuidador, gerando, portanto, uma cultura de que mentir não é danoso. Importante ainda observar que constantemente falsas alegações se repetem numa mesma família, trazendo as mesmas questões novamente ao Judiciário, o que talvez possa também ser efeito de sua forma de funcionamento. 
A manutenção das visitas vigiadas não se revela como uma praxe quando existem acusações em processos de família. Na realidade, poucas vezes a visita é mantida, quando deveria ser usual e suspender um julgamento ou condenação antecipada. Manter as visitas, ainda que de forma controlada, pode suspender efeitos precipitados, tanto na criança como no genitor alienador. A suspensão completa das visitas pode dificultar a avaliação psicológica posterior, pois, para quem acusa e normalmente obtém a guarda da criança, muito frequentemente tem efeito de endossar a tese alegada.

Em casos de programação, com a decisão de suspensão completa das visitas, a SAP se intensifica, aprofundando as falsas memórias na criança. A manutenção das visitas evita o afastamento repentino da criança de uma das figuras parentais, ajudando a frear a SAP, regula o empoderamento de uma das partes e o uso das falsas alegações como forma de obter ganhos no processo, o que, por si, pode impedir de intensificar o nível de programação, e, ainda, evitar que a ruptura entre genitor e criança se torne irreversível. Quando as alegações restam não comprovadas, passaram-se anos. O Judiciário mostra-se impotente muitas vezes para restabelecer o contato entre pais e filhos afastados. A criança alienada e o genitor alienador rejeitam a mudança de status quo mantido por anos, tornando a situação demasiadamente complexa para ser resolvida pela instância judiciária ou até mesmo por outros profissionais. Não seria esse o efeito de uma atuação profissional precipitada que calca uma significação cristalizada a ponto de não poder ser revertida?

Um pai sofria de tentativas de obstaculização de visitas por parte da mãe, mas ainda mantinha proximidade com seus filhos. A mãe, que recebia uma alta pensão alimentícia para as crianças, matriculou os filhos em escola pública e cancelou o convênio de saúde. Em razão desse fato, o pai pediu que a mãe utilizasse o dinheiro da pensão com as crianças ou entraria com ação de redução de pensão. Em seguida, a mãe fez diversas falsas denúncias, inclusive de abuso sexual contra o genitor. Após determinação judicial de suspensão das visitas, passaram-se dois anos e 
meio sem contato com os filhos, quando as alegações revelaram-se falsas. Houve a determinação de obrigação de terapia para as crianças e retorno das visitas ao pai. Uma das filhas já adolescente manteve a recusa veemente em ver o pai e o outro filho retomou às visitas de forma fria e distante, indo poucas vezes até romper completamente o contato. O tempo da suspensão das visitas, crucial para a instalação da SAP, tornou o rompimento irreversível. Neste caso, o juiz teve uma conduta coerente e firme durante o processo, mas a suspensão das visitas tornou o efeito da falsa alegação irreparável. As crianças cresceram, atingiram maioridade e mantiveram-se afastadas do pai, não podendo mais o Judiciário intervir.

Alguns juízes e peritos trabalham de forma coordenada durante 0 processo, ajudando na tomada e no reajuste das determinações. O juiz pode ter um feed back dos efeitos das decisões interlocutórias nas partes. O acompanhamento dos casos a médio prazo, tanto pelo juiz, como pelo perito, também podem ajudar nesse mesmo aspecto. As suspensões dos processos por certo período de tempo ajudam a verificar como a família irá se acomodar com uma decisão provisória. Infelizmente, este tipo de arranjo e manejo requer um tempo maior de dedicação dos profissionais o que via de regra apenas acontece quando diante de ações excepcionalmente complexas. Tampouco deve ser descartada a previsão de um espaço de tempo em que se promovem trocas interdisciplinares, cursos, formação continuada aos operadores e supervisão aos profissionais da saúde. A complexidade da demanda a que devem responder os profissionais ultrapassa muitas vezes a experiência e a formação acumuladas, quando não a própria estrutura oferecida pelo Judiciário aos profissionais.

Outra padronização adotada no meio jurídico deve-se à estreita determinação de visitas aos pais de bebês e de crianças muito pequenas. Filhos são impedidos de terem pernoite com seus pais até que contem com a idade de três anos, por serem consideradas muito pequenas para dormir fora da casa da mãe. Outros pais não podem passar o dia com seus filhos fora da casa da genitora, permanecendo assim durante as 
visitas na sala ou no pátio da casa desta. Nessas situações, são reservados períodos de visitas muito curtos que acontecem geralmente sob a constrangedora vigia do guardião. Determinações como essas alocam o guardião no lugar de autoridade máxima que fiscaliza a capacidade do outro genitor, que fica numa condição degradada. Outro porém deve-se à determinação de visitas de forma que exista necessidade de proximidade entre os genitores para ocorrerem. Em processos litigiosos, esse tipo de contato durante as visitas acaba por gerar mais situações conflituosas, podendo desencadear falsas alegações, aumento da lide familiar e do nível de tensão na criança. Em situações de alta litigância, também se deve evitar a transição das visitas na presença de ambos os genitores. As escolas poder ser utilizadas para aliviar esse tipo de pressão.

Por direito, a boa capacidade de parentalidade do genitor é uma presunção, a exceção deve ser comprovada. No entanto, a precaução excessiva do magistrado pode levar a uma dificuldade de o genitor estabelecer a primeira vinculação com o filho, o que afetará o porvir dessa relação, podendo dar vazão a uma SAP. Gardner frisa o grau da vinculação primária entre pais e filhos como um dos fatores que permitem entender por que a SAP se instala ou não. Não se pode negar a dependência acentuada do infans em relação à mãe e a necessidade de estar mais tempo com ela no início de sua vida. No entanto a interpretação de uma dependência mãe-filho dilatada em relação às possibilidades de esses pais assumirem cuidados e funções pode fazer com que o sistema seja conivente com o afastamento de um genitor. Essa forma de atribuir as visitas pouco ajuda a prevenir casos de SAP, pois constantemente os homens são relegados a um papel secundário, tendo sua autonomia parental retaliada e sendo impedidos de estabelecer uma forte vinculação primária extremamente essencial ao porvir da relação parento-filial. Essas determinações os impedem até mesmo de construírem o savoir-faire cotidiano nos cuidados com os filhos, o que nas ações normalmente aparece como pequenas queixas da mãe indicando 
uma inadequação do pai em ter as visitas e os pernoites. Estabelece-se de antemão um desequilíbrio e desigualdade de poderes que conduzem a um abuso do Poder Familiar, questão princeps em casos de SAP. Ironicamente as crianças passam mais tempo em escolinhas, creches, sob os cuidados de babás e avós do que se permite estarem com seus genitores.

Ainda sobre a questão do fator tempo, a SAP está intimamente ligada à morosidade do sistema judicial e à recusa do tribunal em penalizar o abuso do Poder Familiar. O genitor programador conta com o funcionamento atordoado do sistema judicial, aumentando as chances de sucesso de suas manobras burlarem leis e determinações judiciais. A execução das leis é apenas garantida pela sanção. Na medida em que a sanção excede o conforto do magistrado que atua em casos de família, por envolver menores e relações que são continuadas, os juízes tornam-se por vezes impotentes na execução de ordens judiciais. Soma-se a esta dificuldade $o$ fato de o programador recusar-se a cumprir as determinações, lançar diversas e graves acusações com o fito de confundir os profissionais e colocá-los numa berlinda, além de usar de artifícios para fazer o outro genitor desistir do contato com a criança. O efeito da demora da ação, da falta de assertividade por parte do juiz e do promotor pode levar a uma cumplicidade na prática da violência contra criança e no uso do sistema de forma perversora.

Alguns exemplos práticos demonstram como a incoerência nas intervenções pode fazer o profissional participar da manutenção da SAP. Em uma ação de obrigação de fazer, o juiz determinou multa à genitora a cada visita frustrada. A genitora justificava apenas estar respeitando a vontade da criança;, disse ao filho que pagaria as multas para que prevalecesse seu direito de ir ou não visitar ao pai caso fosse sua vontade. Dessa forma, a mãe anulou a decisão judicial e a criança continuou a resistir fortemente às visitas. O promotor, diante da obstinação da genitora, vendo-se impotente no que cumpria sua função, dirigiu-se à advogada do pai: Dra., desiste da ação, não adianta, a mãe não vai deixar o pai visitar a criança. No processo havia relatório psicológico de 
profissional psicóloga imparcial referindo que a recusa da criança às visitas paternas estava intimamente ligada a uma atitude retaliativa da mãe em relação ao genitor e que, quando na presença do pai, a criança desfrutava alegremente do contato com este. Quase dois anos após abertura do processo, o juiz e o promotor optaram por não sancionar conforme haviam advertido anteriormente. A mãe retirou a criança da terapia determinada judicialmente, dizendo que não poderia fazer algo contra a vontade de seu filho, que passou repentinamente a recusar os encontros com a psicóloga de quem a criança inicialmente tanto gostava. Esta atitude da mãe não foi alvo de atenção por parte do magistrado.

Uma assertiva comum e equivocada no meio psicojurídico em casos de SAP deve-se à corrente generalização de que "a recusa da criança ocorre em razão da briga dos pais", ou ainda que ela é decorrente de uma correponsabilidade dos genitores. Os psicólogos costumam afirmar que a hostilidade da criança a um dos genitores é responsiva à dinâmica familiar. Essa generalização pode poupar esforços em face da dificuldade e do tempo requerido em se diagnosticar a razão da recusa.

Gardner, com sua abordagem, marca a necessidade do profissional frisar o acento da responsabilidade dos genitores em relação à programação sistemática na criança, permitindo uma intervenção orientada para proteção do menor. Há que diferenciar a finalidade da prática clínica e psicojurídica, pois é a partir do norte das disciplinas que se estabelece direção do tratamento/intervenção. Por exemplo, no meio jurídico, enfatizar pequenas dificuldades parentais do alienado, que não justificam o grau de animosidade da criança, pode levar a uma intervenção equivocada por parte dos operadores. No judiciário, a leitura psicanalítica não deve ser considerada hierarquicamente superior à do Direito. Se Lacan acentua a responsabilidade do sujeito por sua posição, seja de alienar ou de se fazer alienado, isso não significa que tal perspectiva deva ser superior à do Direito, que preconiza o direito da criança de convivência com ambos os pais. Segundo Valas (1991), quando Lacan profere que o analítico tem primazia sobre o jurídico, "isso não 
invalida os outros discursos, mesmo que não estejamos no mesmo terreno também não é um encorajamento à delinquência generalizada entre os psicanalistas". (p.142). Diferentemente, na prática clínica, esmiuçar as dificuldades psíquicas do genitor alienado pode aumentar as chances de tratamento. Mas, no meio jurídico, equiparar as pequenas dificuldades parentais do alienado à programação praticada pelo alienador na criança pode encobrir os diferentes níveis de dificuldades psíquicas de cada genitor, contribuindo para perpetuação da situação abusiva na criança que passa pela SAP. Por melhores que sejam os recursos subjetivos de um genitor, eles não garantem que ele não sofrerá rejeição de seus filhos quando programados por um genitor alienador.

A pergunta - o que ocorre numa família que leva um genitor a afastar um pai de um filho ou fazer falsas alegações? - embora seja importante, não deve ser priorizada em detrimento das problemáticas de parentalidade do genitor. A justificativa de tais atos não pode ser entendida a partir de uma resposta do sintoma familiar (também designado como dinâmica familiar), pois viria a desresponsabilizar os sujeitos e encobrir seus atos, deixando de focar questões mais proeminentes, como o abuso infantil.

Houve um caso de uma mãe que levou um tiro acidental de raspão de seu marido durante uma discussão doméstica. Após pedir a separação, a advogada lhe perguntou: Mas o que faremos com as visitas das crianças ao pai? A mãe Ihe respondeu: Vamos manter. Sei que ele ama muito meus filhos e jamais encostaria um dedo neles. O problema sempre foi o ciúme, coisas de casal... Numa situação grave como esta, a mãe teria todas as possíveis desculpas para afastar pai e filhos e ensejar uma SAP, mas fica evidente sua capacidade de separar conjugalidade e parentalidade.

Embora os contextos situacionais possam correlacionar-se com o desencadeamento da SAP, a resposta subjetiva de alienar quando diante de um contexto litigioso não pode ser justificada como uma resposta do tipo ação-reação à resposta do outro. 
Em um caso de programação severa por parte da genitora, quando o pai ligava para falar com os filhos, ao atender ao telefone, a mãe dava gargalhadas, xingava o genitor e chamava os filhos para falar com ele. As crianças eram instruídas a repetirem suas frases. Em voz robótica retrucavam depois das mesmas palavras ditas pela mãe: Papai eu te odeio. Você vai parar na prisão. Nunca mais quero te ver. Não precisa vir na próxima visita. Se você processar a mamãe eu vou te matar. Diante do recuo do Judiciário e em face à grave situação de abuso da genitora, o pai gravou tais ligações como forma de anexar provas ao processo e obter um posicionamento mais firme do magistrado. A perita psicóloga concluiu na avaliação que não se tratava de dar um cunho moralista às atitudes da mãe, pois tão violenta como suas atitudes, eram as invasivas gravações telefônicas do pai que acabavam por gerar uma atitude agressiva da genitora. Na ansiedade em não reproduzir a criticada divisão do Judiciário entre vítimas e algozes, culpados e inocentes, a psicóloga, numa visão simplista, equiparou problemáticas que devem manter-se diferenciadas para permitir a real proteção da criança. Dessa forma, houve uma desresponsabilização do genitor programador pela prática abusiva insidiosa e direta na criança. Há que se marcar a diferença entre o intenso conflito conjugal entre as partes e que atinge a criança e o direto abuso psicológico do programador na criança.

Um pai se queixava de que a mãe estava dificultando o contato com seus filhos. Afirmava que, quando ia buscar as crianças, a mãe criava uma situação de embate na porta de casa de forma que sempre ameaçava fazer Boletim de Ocorrência de agressão física sem que tais agressões tivessem ocorrido. A genitora fazia cenas dramáticas e os vizinhos e porteiros vinham correndo por achar que algo estava acontecendo. $O$ genitor acreditando que assim ela preparava testemunhas, insistiu para pegar as crianças na frente da portaria, o que foi por ela recusado fazendo o pai entrar para pegar os filhos. Temendo consequências legais da Lei Maria da Penha, o genitor optou por regular as visitas via judicial pedindo que as crianças fossem diretamente retiradas na escola, para que não 
tivesse contato com a genitora. Durante a audiência, a mãe insistiu que entregar os filhos dentro do prédio evitava exposição a assaltos, frio e chuva. O pai persistiu em seu pedido, quando o promotor disse: Quando o Sr. perceber que ela está num dia ruim ou que ela está nervosa, o Sr. vai embora e retorna na próxima visita para pegar seus filhos. A responsabilidade pela briga é dos dois, o Sr. precisa entender isso. As atitudes do pai foram interpretadas como uma atitude litigiosa, numa equivalência à obstaculização de visitas por parte da mãe junto a falsas alegações que ocorriam havia meses. Uma leitura equivocada como esta por parte de um profissional pode ajudar a intensificar uma SAP.

Outro caso de obstacularização de visitas pode trazer uma relativização interessante quanto ao que foi exposto anteriormente. 0 pai, policial civil, tinha uma conduta abusiva, praticando assédios intensos contra a ex-esposa. O ciúme muitas vezes disparava agressões verbais intensas que chegavam algumas vezes à agressão física. A mãe mudou-se repentinamente de cidade com a criança e passou a praticar pequenos atos de alienação parental, que não consubstanciavam uma programação sistemática. Suas condutas eram mais correlativas às fortes contingências momentâneas de sua vida do que a intensas dificuldades psíquicas. Um trabalho de orientação ao genitor surtiu efeitos transformadores de modo que a ação perdeu sua razão inicial. O genitor que se dizia altamente injustiçado pela alienação cometida pela ex-esposa pôde implicar-se na participação da alienação parental que ele buscava frear através da ação, sem saber que, em sua posição subjetiva, se fazia ser alienado. As visitas voltaram a transcorrer normalmente, restabelecendo-se um contato respeitoso entre as partes. No entanto, há que destacar que a mudança de posição subjetiva do pai não garante o retrocesso da SAP, especialmente quando a programação do genitor alienador deve-se mais a uma cristalização de uma posição subjetiva, pouco se relacionando com a posição subjetiva do outro genitor. Importante ressaltar, porém, que Gardner adverte que diminui a probabilidade de caracterizar-se uma SAP em situações familiares de 
violência doméstica ou outros tipos de abuso, tanto contra o genitor ao qual a criança se alia ou contra a própria criança.

Mais um caso permite clarear a discussão em questão. Certo pai, sempre muito presente na vida dos filhos, enamorou-se novamente e decidiu casar-se. As visitas aos filhos transcorriam normalmente até que por algumas vezes a mãe passou a não entregar as crianças e buscá-las no meio do final de semana na casa do pai. Ligava durante as visitas paternas para saber se os filhos estavam bem e perguntava se desejavam voltar para a casa da genitora.

Observou-se que o pai passou a excluir os filhos de forma significativa da vida que constituía com a nova esposa. Passou a não mais buscá-los nas visitas em meio à semana, e nos finais de semana passou a buscar os filhos no horário e dia que lhe era conveniente, sem avisar a genitora. Queria permanecer o máximo de tempo com a nova esposa. Essa atitude provocou reações de ciúme por parte das crianças, que passaram a queixar-se para a mãe das atitudes paternas, não sendo portanto uma animosidade correlativa a SAP. A mãe, por sua vez, passou a impor condições e limites nas atitudes do pai, o que tampouco revelou ser atitude retaliativa, sendo mais uma atitude protetiva. $O$ pai, por sua vez, passou a dizer-se alienado. No entanto verificou-se que, quando o pai não buscava os filhos, conforme determinado judicialmente, a mãe não mais permitia que buscasse em meio ao final de semana. Ligava para saber se estavam se sentindo bem em face do ciúme e do desinteresse do pai em dedicar-se aos filhos. O posicionamento da mãe neste caso, diferentemente de uma programação, constituía uma forma de barrar o tratamento que o pai vinha dando aos filhos. Apesar de todo o entorno conflituoso entre os pais, os filhos gostavam e queriam conviver com ele, o que não seria o caso se a mãe fizesse uma programação.

Nestes dois casos, a posição das genitoras não era compatível com programação. Não se tratava de uma prática insidiosa e abusiva em relação às crianças e o objetivo das genitoras não era o de excluir os filhos da vida do genitor. Em casos desse tipo, observam-se boas chances 
de sucesso na transformação do conflito entre as partes através de meios alternativos de resolução de conflito. Aquilo que é próprio do sintoma do casal parental ou, segundo a Psicologia, à dinâmica familiar, pode ajudar a discernir nuanças que permitam a melhor intervenção no caso particular.

Por outro lado, algumas vezes, ressaltar o sintoma do casal (dinâmica familiar) em detrimento de práticas abusivas parentais pode trazer confusões na orientação dos operadores, principalmente quando se trata de uma SAP. Para esses casos, Gardner criou uma abordagem diferenciadora no acento dessas questões, pois a resolução alternativa de conflito, como a terapia ou a mediação em casos mais agudos de programação, leva a uma piora da situação, na medida em que é utilizada como forma de obter vantagem, ganhar tempo e burlar recomendações. Quando a alienação é promovida em face de importantes dificuldades psíquicas, a rigidez na posição do alienador impede que se obtenha uma cessão no gozo do filho como posse, inviabilizando acordos ou um diálogo produtivo. De acordo com Kopetski, Rand e Rand (2006), na década de 1970, Kopetski tratava de crianças que recusavam o contato com o genitor depois do divórcio de seus pais. A autora concluiu que "determinações de obrigação de visitas ou a inversão de guarda em favor do genitor alienado eram sempre efetivas em interromper a alienação, enquanto a terapia como intervenção primária falhava". (p. 65)

Houve um caso de SAP em nível severo no qual a mãe havia feito uma falsa alegação de abuso sexual em meio ao processo. Depois de a equipe técnica concluir a inexistência do abuso sexual, o juiz indicou a criança para tratamento e o casal para mediação, suspendendo a ação por alguns meses. A mãe tentava convencer a equipe de mediação com cenas dramáticas, gritos e choros de que o abuso teria ocorrido. Na medida em que os aspectos práticos de um acordo de retomada de visitas com o pai vinham à tona, ela intensificava suas reações. Como forma de escapar à mediação e à terapia indicadas pelo juiz, dizia às mediadoras que a terapeuta da criança havia proibido a retomada de visitas ao pai e dizia à terapeuta da criança que as mediadoras queriam confrontar a criança na 
frente do pai sobre o porquê de ele o rejeitar. A mediação e o tratamento estavam sendo utilizados como forma de ganhar tempo e burlar o sistema judiciário, o que levanta questionamentos com relação à contraindicação desse método em casos de alta litigância, como os de SAP.

A ideia prévia de que o genitor alienado apresenta uma passividade ou conivência que justificaria a atitude do alienador e o sucesso deste em instalar a SAP na criança, também pode levar a uma atuação conivente com a SAP. O diagnóstico deve levar em conta em que medida a criança responde a essa dificuldade pessoal do alienado e em que medida a criança responde a um imperativo do outro genitor para que dele se afaste. São cálculos delicados e complexos, no entanto importantes e necessários nos estudos para o momento de intervir precisamente e não intensificar a posição de gozo de um genitor que aloca criança como objeto de posse.

O conservadorismo adotado nas posturas profissionais também pode gerar uma tendência a estimular o abuso do Poder Familiar, por exemplo, o automático estabelecimento de guarda em favor das mulheres sem exames mais acurados. Um processo de disputa de guarda iniciou-se no interior a pedido da genitora, com a sua mudança sorrateira durante seu período de férias com o filho. $O$ pai, após quinze dias de férias sem ver o filho, esperava pegá-lo na escolinha no seu dia de visita, sendo surpreendido com telegrama avisando sobre a liminar de guarda - a mãe já havia se mudado com a criança de cidade.

$\mathrm{Na}$ contestação do pai, havia provas fundamentadas sobre a rotina da criança com os pais, que evidenciava uma guarda compartilhada na prática. Incluíam relatório de terapeuta escolhida pelos pais para tratar a criança no pós-divórcio, confirmando a ampla participação dos dois na vida do filho, a adaptação da criança à nova escola e o amplo esquema de convivência entre os pais depois da separação. Também constava do relatório a agenda escolar, indicando o tempo igualitário de convivência do filho com os genitores e a participação ativa deles na vida escolar da criança. 
Tais documentos passaram em branco na tomada de decisões. Concluiu o promotor: Pela Lei da natureza o filhote acompanha sempre a mãe. Mesmo com fortes indícios favoráveis ao pai, observa-se a dificuldade de os operadores considerarem evidências muito claras, dispensadas em nome de uma cultura passada, que revela um ranço tradicionalista e a pouca consideração dos aspectos sociais e da família moderna. Pedidos de guarda junto à mudança de cidade por parte das genitoras são facilmente concedidos sem que se atente para a possibilidade de SAP. Muitas vezes a mudança de cidade pode ser utilizada como forma de dificultar contato entre os filhos e genitor e obter vantagens processuais. Há ainda que se considerar a adaptação da criança à escola, as amizades, a família estendida e a cultura no local em que reside, o que geralmente passa despercebido.

A guarda compartilhada tem sido alvo de resistência por parte dos magistrados, mesmo após a aprovação da Lei, com a justificativa de que, quando existe litígio, decisões parentais conjuntas tornam-se impraticáveis. Acredita-se que o que por um lado viria equilibrar os poderes, por outro poderia aumentar o litígio. Evidentemente que esse tipo de regulação de guarda pode dar margem a duas decisões laterais arbitrárias e deve ser evitado quando a intenção no pedido é de barganha. Ocorre que essa lógica torce o direito dos filhos previsto nas leis, pois seu intuito primeiro leva em consideração um pseudoapaziguamento dos conflitos entre os genitores. Quando não há diálogo, escolhe-se um genitor unilateralmente para tocar as decisões relativas à vida dos filhos em detrimento dos interesses das crianças - a ampla participação dos genitores na sua vida.

Brito (2003) examina os argumentos dos operadores do Direito contrários à adoção da guarda compartilhada no litígio. A autora desconstrói conceitos e preconceitos concluindo que esse arranjo familiar serve de suporte à ancoragem social e ao exercício da paternidade. Portanto, há que evidenciar, para além das questões da lei estrita, seu valor social e simbólico, no equilíbrio das atribuições do tão complexo 
Poder Familiar no pós-divórcio. Em casos em que um dos genitores tende a abusar do Poder Familiar, esse tipo de guarda pode ajudar a regular essas situações, dentre elas, a mais grave, a SAP. No capítulo 2, citou-se um entendimento diferenciado por parte dos magistrados, em casos de guarda compartilhada, não referendando decisões unilaterais por parte das genitoras em mudar de cidade com seus filhos. O efeito subjetivo da atribuição de uma guarda compartilhada pode evitar alimentar a sensação de posse dos filhos a quem detém a guarda única e relegar o outro genitor ao papel secundário de visitador, termo impróprio conforme referido anteriormente.

A autonomia jurídica correlativa às idades de 12 e de 18 anos parece refletir de forma artificial as situações reais. Parte-se de uma interpretação equivocada do Estatuto da Criança e do Adolescente (ECA) que permite que a criança adotada possa ser ouvida quanto à sua vontade, quando completa 12 anos. Nos litígios familiares, verifica-se comumente nos filhos o fenômeno que Gardner designou pensador independente. O genitor, geralmente guardião, no intuito de obter ganhos processuais, alinha a criança ao seu lado para conseguir apoio deliberado desta em seus pedidos no processo. As crianças passam a ser inseridas na lide parental até mesmo ansiando para darem recados ao juiz ou perito. Até mesmo escrevem cartas fazendo pedidos ou desmoralizando a parentalidade do outro genitor. Ouvir a criança, perguntar sobre sua vontade pode significar um posicionamento equivocado do profissional.

Para a psicanálise, a escuta dos sujeitos permite diferenciar latente e manifesto, enunciado e enunciação, para que se possa balizar uma intervenção a partir da posição desejante dos envolvidos evitanto o engano da leitura imaginária e fantasmática induzida pelo enunciado. A criança, na condição dependente, ama ao pai e à mãe, portanto não deve ser levada a acreditar que pode ou deve ser responsável pela escolha de qualquer questão prática relativa ao processo, pois significaria escolher entre lealdade a um dos seus pais e traição ao outro. Esse tipo de atuação pode trazer sofrimento, culpa e marcas no seu porvir. 
Um pai de dois meninos conseguia administrar a intensa programação por parte da mãe havia muito. Por longos anos, no momento da transição das visitas, a genitora cuspia, xingava e desferia tapas no pai. Apesar da intensidade do litígio, o pai mantinha um bom contato com os filhos. Porém, quando ajuizou ação para estender as visitas de feriados prolongados, o juiz indeferiu o pedido do pai mantendo as visitas homologadas em ação anterior - visitas quinzenais e uma pernoite semanal. O pai, tomado por briguento por ajuizar ação com pedido tão pequeno, além de ter seu pedido indeferido, escutou sermão do juiz: Criança deve ir apenas quando quiser. Não coincidentemente, na visita subsequente à frase proferida pelo magistrado, as crianças recusaram a primeira visita paterna. Disseram que tinham uma comemoração e queriam ir apenas no outro dia para a casa do pai. Numa atitude cada vez mais evasiva, os filhos foram se afastando. Cada dia surgiam novas desculpas evitativas até o vínculo romper-se completamente. Os filhos passaram a não mais atender seus telefonemas nem descer quando ele chegava para pegá-los. A leitura equivocada da situação familiar pelo profissional levou a um endosso das atitudes alienadoras por parte da mãe, que passou a ter uma autorização expressa para alienar, o que antes, de certa forma, estava contido.

\subsubsection{Alienação nas escolas}

A alienação como problema cultural atinge também as escolas, revelando que existe necessidade de um trabalho a ser feito nessas instituições. Até mesmo escolas de grande porte se veem confusas quanto à sua posição ao lidar com as demandas dos pais separados.

Informações a respeito do aluno muitas vezes são passadas apenas a quem detém a guarda. Os educadores até mesmo desconhecem a nova Lei no 12.013/2009, que determina a obrigação de as escolas passarem as informações dos alunos a ambos os pais depois da separação. Ou ainda, quando conhecem a lei, passam apenas a informação estritamente 
necessária, deixando de lado seu caráter maior - o tratamento igualitário dos pais e o interesse das crianças em tê-los ampla e igualmente participando de sua vida escolar.

Comumente a equipe escolar sente-se dividida em casos de conflito entre os pais, muitas vezes adotando posturas não claras ou coniventes com o genitor alienador. Existe uma demanda de pressão constante e insistente do programador em relação à escola, envolvendo-a no litígio. Ele busca uma proximidade com professores e coordenadores para atualizar detalhes do processo, dos conflitos, desmoralizando a imagem do outro genitor. Pode expor a intimidade da vida familiar, trazer histórias dramáticas e cópia dos processos e até mesmo fazer falsas alegações para garantir cumplicidade nos seus pedidos de excluir o outro genitor.

Ao outro genitor, quando ele tenta estabelecer um contato próximo com a equipe escolar, o mínimo de informações e detalhes é passado. Geralmente este é recebido em situação de resistência e de desconforto pelos profissionais. Como o genitor não tem acesso à produção e informações da criança, busca a escola na esperança de participar de forma mais ativa na vida do filho. No entanto, o acesso à produção e informações sobre a criança, como agenda, relatórios, notas, faltas, atividades, circulares, reuniões, muitas vezes é dificultado pela escola. Algumas justificam-se evasivamente, alegando que a obrigação de passar as informações é do genitor guardião e nada podem fazer se ambos não se entendem. No entanto, de acordo com a Lei referida, a escola não pode impedir o genitor de ter acesso a quaisquer informações sobre a criança quando procura a instituição.

Certo pai não tinha acesso à vida escolar do filho, pois a mãe enviava para sua casa apenas o material didático sem a agenda da criança. O genitor aproveitou sua ida à escola para ver os trabalhos feitos pelo filho e olhar a agenda. A professora recusou-se a entregar-lhe a agenda, fornecendo apenas os trabalhos que deveriam ser olhados $e$ devolvidos. Justificou que não entregaria a agenda, pois iria expor a genitora que a usava para escrever recados e se comunicar com a escola. 
A confusão dos profissionais quanto ao seu papel é tão frequente nesse tipo de situação familiar que se torna regra. A agenda escolar fornece informações cotidianas sobre as crianças, motivo pelo qual muitos genitores alienadores impedem o acesso, tomando-a como posse. A escola por sua vez esquece que a agenda é da criança, sendo do direito e interesse do menor que ambos os pais estejam a par de seu dia a dia escolar.

Certa escola recebeu advertência de multa por recusar-se a fornecer cópia do relatório anual da criança ao pai. As informações eram passadas à mãe que se recusava a entregá-las ao pai. Este, por sua vez, dirigiu-se à escola para receber o relatório de aproveitamento do aluno antes que a mãe levasse tal relatório para sua casa. A escola disse que apenas entregaria à guardiã e pediria que ela, depois de ler, repassasse ao pai. Tanto a escola como a mãe recusaram-se a entregar o documento ao pai. Este informou ao juiz do processo, assim a escola foi advertida e obrigada a entregar os documentos ao pai. O genitor dirigiu-se à escola com a informação de que o juiz ordenara a entrega do tal relatório. Desta vez a coordenadora entregou um envelope com diversos documentos relativos à produção grupal da sala, sem conter o relatório individual do seu filho. A profissional informou que a única cópia do relatório do aluno foi entregue à mãe, pois foi escrita à mão, recusando-se a fornecer novo relatório ao pai. O juiz determinou multa à instituição, caso não permitisse acesso do pai ao relatório.

A situação de lide entre os pais traz aos profissionais da escola a necessidade de um maior empenho e dedicação a cada família em particular. A realidade de pais separados, cada vez maior na atualidade, torna importante um treinamento profissional mais assertivo e preparado para lidar com essas situações delicadas.

Existem casos de genitores alienadores tão obstinados, que, quando - genitor alienado consegue boa relação com a escola e obtém informações escolares, arbitrariamente mudam a criança de escola. Houve caso de uma criança que sofria fortemente com a adaptação às escolas e, 
mesmo assim, a mãe a mudou de escola cinco vezes em quatro anos, mudava toda vez que o pai contornava a resistência das escolas em recebê-lo e passar informações.

O guardião alienador beneficia-se do termo guarda única e dos seus efeitos sociais para tomar decisões unilaterais relativas a escola, saúde, tratamentos, viagens, terapia. Houve certa mãe que forneceu cópia do acordo de visitas e guarda homologado judicialmente para impedir que o pai tentasse visitar o filho na escola. A escola impedia o pai vê-lo na escola, pois, segundo a ordem judicial, as visitas paternas eram apenas nos finais de semana; assim o genitor alienado não tinha direito de ver a criança fora de seu período de convivência. O juiz determinou que o pai deveria retirar a criança diretamente na escola. Mas a mãe informou à escola que o pai não poderia ir ao colégio nos outros dias ver o filho, pois nos dias que não eram de visita, ele não tinha direito de ver a criança,

uma vez que poderia fugir com ela. Quando o pai foi, certo dia, buscar a criança mais cedo na escola, em seu dia de visita, teve problemas ao retirar a criança uma hora antes de seu horário, pois as visitas eram designadas apenas depois do horário de saída da criança. O estabelecimento de guarda compartilhada em casos desse tipo pode trazer um efeito social de forma a reequilibrar o poder familiar no pós-divórcio em casos de SAP.

\subsection{PROFISSIONAIS}

\subsubsection{O juiz}

Alguns juízes relutam em estabelecer condutas mais firmes ou sanções em casos de SAP, talvez por temerem que a recusa da criança seja genuína. O desconforto do juiz em sancionar as atitudes do programador deve-se à possibilidade de a intervenção aumentar o conflito familiar, a pressão sobre a criança ou desencadear actings por parte de 
quem não aceita as ordens judiciais. Por este motivo, Gardner criou uma ferramenta que propõe sanções progressivas no grau de restrições e coerções de forma que permite um feed back da resposta familiar para o juiz fazer esse difícil cálculo. Nos casos mais graves, nos quais as crianças não têm contato algum com o genitor e demonstram intensa hostilidade, as intervenções devem ser mais cautelosas para evitar deslindes dramáticos.

A sanção, a palavras como ato de um juiz pode surtir um efeito de corte, freio no gozo do alienador que aloca a criança como objeto de gozo. Esse ato surte efeito na transferência entre a criança e o alienador, restabelecendo o lugar da alteridade, do terceiro, e reconectando a transferência da criança ao outro genitor. Frequentemente, uma decisão interlocutória, um posicionamento do promotor ou do juiz em audiência surtem efeitos imediatos no par criança-alienador. Por esse motivo, crianças que rejeitavam o outro genitor passam, do dia para noite, a conviver normalmente com ele.

Certa mãe, questionada na perícia sobre a alegação de abuso sexual, mudou de assunto dizendo apenas que sabia que seu ex-marido não faria uma coisa daquelas. Antes da perícia, a genitora foi advertida pelo juiz devido à montagem de acusação de abuso sexual ser muito suspeita. A direção no processo dada pelo promotor e juiz a fez recuar na alegação e ela aceitou que as visitas fossem retomadas imediatamente após a conduta do promotor e do juiz. A criança imediatamente parou de recusar as visitas do pai.

Há casos em que, mesmo com sucessivas sanções, o programador resiste firmemente a qualquer mudança de posição, lançando mão de artifícios cada vez mais arriscados e impulsivos. Nestes momentos, ele pode fazer uma falsa alegação contra o outro genitor para tentar reverter o curso do processo, sumir com a criança, entre outros.

Depois de uma advertência, a genitora resolveu permitir as visitas. No entanto, continuou trazendo fortes imperativos para os filhos 
recusarem o pai. Os filhos tentaram abrir a porta do carro durante uma via movimentada para saltar e fugir do pai.

Quando a hostilidade das crianças é severa, as visitas forçadas podem trazer riscos. Gardner propõe uma inversão de guarda de forma progressiva via um terceiro neutro. Ele criou essa ferramenta auxiliadora pelo fato de casos mais graves oferecerem desafios à prática profissional.

No meio legal, a importância de realizar esse diagnóstico detalhado permite com que seja averiguada a veracidade das alegações e para que sejam tomadas as medidas de proteção à criança, se necessário. Por exemplo, a recusa da criança pode ser em resposta a dificuldades do genitor com relação à parentalidade, não a uma programação.

Uma criança de 4 anos costumava reclamar que não queria ir às visitas ao pai. Ele apresentava sinais de depressão, agressividade e início de alcoolismo. O pai faltava algumas vezes às visitas e não avisava. Quando levava a filha para passear, ao invés de proporcionar programas infantis, levava-a para ficar todo o dia num bar, para poder beber e encontrar os amigos. A criança queixava-se do programa e às vezes não queria ir às visitas. A mãe conflituosa achava que não devia permitir a saída da criança que insistia para ir com o pai, pois tinha receio de sua reação, se contrariado. Certas dificuldades do genitor podem levar a criança a apresentar uma rejeição, porém, nestes casos, as evidências clínicas da rejeição adotam características diferentes das presentes em caso de programação.

Alguns casos de genitor com questões relativas a agressividade, depressão, ou desinteresse em relação à criança podem fazê-la recusar-se ao contato. Em outros casos, quando genitores querem retomar a relação, depois de por um longo tempo sem visitar a criança, podem ser rejeitados por ela. No entanto, nos casos de SAP, pequenas dificuldades de um genitor são transformadas em acusações graves para explicar a recusa da criança e acobertar a manipulação do programador. Crianças violentadas, maltratadas por um genitor, podem passar a recusá-lo. Crianças que 
observaram frequentes violências domésticas contra a mãe podem passar a recusar o genitor agressor.

Diferentemente de curar ou resolver um problema complexo com um simples texto de lei, a proposta da Lei $12.318 / 2011$ permite que a sanção do juiz ajude a administrar o problema e impedir a ruptura dos laços parentais. Dessa forma, a Lei não cumpre com o objetivo de curar uma patologia, mas pode evitar uma inversão de guarda, diminuir a programação na criança e o rompimento dos laços.

\subsubsection{O advogado}

A formação dos advogados, principalmente na área da família, por se tratarem de relações continuadas, deve incluir uma mudança da cultura do litígio.

Alguns advogados desestimulam a participação de seus clientes da mediação por não acreditarem que seja assunto digno de atenção ou que a mediação diminui a importância do trabalho do advogado para o cliente. No entanto, paradoxalmente, esse tipo de conduta gera mais conflito na família.

Se, de um lado, o advogado do genitor alienado pode demorar em tomar certas atitudes e entender a gravidade da situação, do outro, o advogado do genitor alienador pode adotar uma postura conscientemente e deliberadamente obstrucionista.

O advogado deve-se ater que a recusa, hostilidade ou críticas da criança a um dos genitores não podem ser endossadas de forma acrítica. A fala deve ser interpretada visto que os filhos não se resumem ao que os pais dizem e interpretam sobre eles. Sustentar esse querer hostil da criança pode levar a indução do fenômeno de independência, apontado por Gardner como uma verdadeira confusão da vontade enquanto "direito da criança". Por de trás de um discurso de "direitos da criança", pode pairar um abuso psicológico por parte de um genitor vingativo e ser sustentado pelo advogado. 


\subsubsection{O psicólogo: perito, terapeuta e avaliador}

O profissional da Psicologia - seja o terapeuta, o avaliador, o assistente técnico ou o perito - deve ser advertido quanto aos efeitos de seu trabalho em famílias que passam por litígio.

Pareceres psicológicos unilaterais têm o poder de surtir efeitos no processo, podendo levar a equipe a atuar de forma pouco crítica e precipitada. Por isso, o Conselho Federal de Psicologia (CFP) criou duas resoluções recentes que visam estabelecer regras mais claras sobre a atuação e papel do profissional psicólogo. Por exemplo, não raro as partes procuram o psicólogo para endossar suas teses e teorias acerca da situação familiar, sobre a criança ou sobre o outro genitor e obter ganhos processuais. O uso inadequado do profissional em situações de conflito conjugal ocorre quando ele é chamado a responder ou emitir documentos e acaba por fazê-lo sem se ater às normas da profissão, aceitando tais pedidos de forma pouco crítica. Os promotores e juízes, quando diante de documentos unilaterais, devem observar alguns requisitos extremamente importantes nos trabalhos apresentados.

Segundo a resolução do CFP 10/2010, o psicólogo deve chamar todos os envolvidos na situação de suspeita de violência para a avaliação. Esse cuidado profissional permite avaliar a qualidade da avaliação, a isenção do profissional e a confiabilidade. No caso de uma das partes não ser avaliada, a resolução determina que o profissional deve revelar a razão e ressaltar o impacto da não inclusão da participação da pessoa no estudo. Uma falsa alegação, depois de endossada pela equipe, traz efeitos no psiquismo de todos os envolvidos (criança, acusador e acusado), sendo dificilmente revertida mesmo depois de se provar infundada.

Não raro, além da legitimação do Judiciário em relação aos impedimentos de convívio entre pais e filhos, os terapeutas podem ajudar a adiar a possibilidade de resgate dos laços familiares rompidos na SAP e até mesmo induzir as partes ao aumento da vitimização e da 
agressividade em relação ao outro. Dessa forma, a ratificação que o profissional faz da posição tal como apresentada, dificulta a elaboração de uma resolução psíquica e induz os envolvidos no litígio ao acting out ou passagem ao ato para saída do intenso impasse subjetivo.

Uma genitora justificava inúmeras e graves falsas alegações contra o genitor, de forma evasiva e fantasiosa. O genitor, por sua vez, praticava assédios e agressões contra ela. Ambos também praticavam intensos atos de alienação parental contra a filha, que por sua vez resistia à instalação da SAP. A mãe fazia tratamento psiquiátrico e psicológico, porém a terapeuta reforçava a sua posição de gozo induzindo-a a mais atuações, falsas alegações e ao aumento do conflito entre o ex-casal. A paciente contava histórias dramáticas de assédio praticadas pelo ex-cônjuge, ao que a terapeuta acrescentava: Tome cuidado, ele é psicopata. Vai tentar te manipular. A genitora passou cada vez mais a ficar apavorada com fantasias que brotavam e que não eram adequadamente tratadas pela psicóloga. A mãe passou a querer afastar a criança do contato com o pai terrivelmente perigoso em sua fantasia. A terapeuta não viu outra saída a não ser orientar a mãe a afastar-se da criança por determinado tempo até que recobrasse seu equilíbrio e parasse de fazer sucessivas falsas alegações que poderiam prejudicá-la judicialmente.

Com relação ao trabalho do perito, a carga de trabalho inviabiliza a adoção de um número maior de entrevistas para um estudo mais criterioso, minucioso e aprofundado. Diferentes conclusões a que se chega podem se relacionar aos níveis diferentes de profundidade nas avaliações. $\mathrm{O}$ baixo número de entrevistas com as partes, conforme tem sido praxe nos setores técnicos, prejudica as conclusões a que se chega. Para a psicanálise, a transferência é o que permite o diagnóstico ${ }^{16} \mathrm{e}$, para que ela se estabeleça, há necessidade de um atendimento às partes que vá

16 A utilização de um número maior de entrevistas com as partes no enquadre judiciário é um procedimento frequentemente criticado pelos profissionais por mobilizar a transferência e não poder tratá-la. Conforme foi desenvolvido anteriormente, a transferência por ser um fenômeno universal se dá em todas e quaisquer relações humanas, ou seja, a questão que se trata aqui deve-se mais ao seu manejo técnico do que ao seu desencadeamento. 
além do fenomenológico, isto é, da fala verbal, do comportamento e das reações apresentados, para que se possa realizar uma leitura a partir das posições subjetivas, ir além da extração da verdade através da confissão, que pode ser altamente enganosa ao profissional. Mesmo que a criança recuse veementemente um genitor, há que ir além da sua fala verbal, é isto que Gardner propõe: que se diferencie sua fala e posição subjetiva, desejante.

A complexidade da demanda a que os operadores do Direito são submetidos exige uma formação continuada, supervisão dos atendimentos dos profissionais da área da saúde mental e treinamento especializado. Nos EUA, os conselhos que regulam as atividades na área da saúde mental utilizam protocolos ${ }^{17}$ detalhados para definir as atuações. Profissionais que atuam em perícia devem ter experiência comprovada na área específica, cinco anos de supervisão, além de seguir certos padrões nos atendimentos durante as avaliações. Por exemplo, o psicólogo chamado a avaliar suspeita de abuso deve incluir em sua avaliação métodos para detectar falsas alegações de abuso sexual.

\subsection{DIAGNÓSTICO DIFERENCIAL}

Nem toda obstacularização de contato ou tentativa de desmoralização de um genitor constitui uma SAP, embora possam ser coibidas segundo a Lei brasileira, por se constituírem atos de alienação parental. Entender as nuanças de cada caso permite a indicação de intervenção/tratamento adequados a cada situação familiar, evitando atuações precipitadas que gerem danos secundários.

Conforme referido anteriormente, segundo Freud, todas as relações comportam ambiguidade. Filhos criticam seus pais, no entanto, depois do divórcio resta saber se o genitor utiliza as críticas da criança a fim de

17 Um dos protocolos em questão é da American Academy of Child and Adolescent Psychiatry:

http://www.aacap.org/cs/root/policy_statements/guidelines_for_the_clinical_evaluation_ for_child_and_adolescent_sexual_abuse 
incorporá-las numa campanha de desmoralização contra o outro genitor, isto é, se existe o manejo da transferência com esses fins específicos.

Certos tipos de rejeição ou animosidade em relação aos genitores são típicos do pós-divórcio mesmo quando não existe programação. A criança pode resistir à transição entre as casas dos pais até mesmo de forma veemente chorando, gritando e até deferindo hostilidade. Inadvertidamente, os pais trocam acusações mútuas de que o outro induz propositalmente a criança num jogo. No entanto, deve-se verificar qual tipo de rejeição a criança desenvolve, se há um formato de campanha na recusa ou se apenas um dos genitores é criticado. Na SAP, além de a rejeição ser unilateral, outros indicadores aparecem, os quais devem ser observados antes de diagnosticá-la.

Portanto, os casos de separação que envolvem litígio quase que invariavelmente são acompanhados de algum tipo de sintoma presente na SAP, seja na criança, seja no alienador. A rigidez na posição alienadora, isto é, alocar o filho como instrumento de retaliação é um importante termômetro para verificar os prejuízos na capacidade de parentalidade do genitor que a pratica. É esperado que a intensa hostilidade em relação ao ex-cônjuge arrefeça progressivamente depois de passado certo tempo da separação. No caso da SAP, o projeto vingativo mantém uma intensa devoção desejante do alienador em manter a programação, favorecendo a sustentação da Síndrome na criança. Em razão da rigidez de sua posição subjetiva, do intenso gozo em se colocar no lugar de vítima do outro genitor, mantém uma ruptura passada a todo momento, alimentando dessa forma intensos sentimentos hostis que impedem esse genitor de engajamentos desejantes.

Nos conflitos de lealdade, a criança dividida entre os dois genitores litigantes não escolhe veementemente um dos lados. Quando existe uma demanda mais forte, o que pode ser caracterizado por programação, a criança alinha-se de uma forma muito particular a um dos genitores. Porém, segundo a definição jurídica de atos de alienação parental, pode- 
se encontrar, na grande maioria dos processos de separação litigiosa, algum tipo de ato alienador, até mesmo por parte de ambos os pais.

Uma família que passava por uma alegação de abuso sexual disparada pela mãe contra o genitor mostrou ser real o fato, embora também apresentasse alguns indicativos de sintomas da SAP. No entanto, no curso do processo, verificou-se que, após a detecção do abuso, a mãe passou a promover alguns atos de alienação parental, embora não fossem em formato de campanha, prejudicando mais a recuperação psíquica do filho. A criança apresentava as exatas mesmas falas da mãe Meu pai é um monstro, Meu pai faz eu passar fome, Meu pai deixa eu pegar chuva, entre outros, o que Gardner caracterizou por cenários emprestados. Além disso, a genitora não cooperava com o tratamento psicológico do filho, ao qual fora enviado pelo juízo. A psicóloga afirmou no documento que as atitudes maternas estavam promovendo um abuso psicológico no filho e gerando fortes crises de angústia. Segundo Gardner sugere, não se deve utilizar o diagnóstico de SAP em situações de real abuso. Verifica-se, portanto, que o fato de haver alguns indícios semelhantes aos presentes na SAP não exclui a necessidade de o profissional avaliar a possibilidade de abuso.

Um caso de suspeita de SAP, ao contrário do que aparentava, revelou-se um abuso real. Uma mãe procurou a psicóloga indicada por sua advogada, pois desejava suspender as visitas paternas ao filho, alegando SAP. A advogada pediu uma rápida avaliação à psicóloga para orientar seu trabalho, indicando ou desaconselhando a ação. Diferentemente do caso anterior, a postura da profissional de Direito, por ser crítica e cautelosa, revelou o intuito de esclarecer a situação familiar antes de dar início a ação judicial, que poderia trazer prejuízos importantes a todos os envolvidos.

A mãe alegava que a criança estava sendo alienada pelo pai, pois este tinha fortes crises de raiva contra a mãe, na frente da criança, o que estava fazendo o filho afastar-se dela. A criança de seis anos retornava para a residência materna agressiva, recusando-se a falar com a mãe por 
até cinco dias. Essa observação trazida causou estranheza, pela força da alienação na criança, promovida em visitas muito espaçadas ao pai (quinzenais). No entanto, o que fora relatado pela mãe não era condizente com os elementos presentes na SAP.

Ao longo da avaliação, aos poucos foi revelado que a criança estava sendo abusada durante as visitas paternas e que a resposta da criança (agressividade) interpretada pela mãe como SAP, eram um sintoma referente a uma situação de abuso sexual. A raiva da criança deferida contra a mãe, parte era responsiva ao abuso sofrido, parte se referia às intensas agressões do pai à mãe e parte advinha de uma raiva contra a genitora por esperar uma proteção que não acontecia. No lugar do acolhimento, a criança recebia broncas e censuras da mãe ao seu comportando sexual. Ela o considerava inadequado, sem se ater ao abuso sofrido pelo seu filho. Em função das observações deste caso, ficou evidente a necessidade da inclusão no estudo do "diagnóstico diferencial da rejeição da criança" em torno do qual se orienta o estudo de Gardner sobre SAP e AP.

Quando existe suspeita de abuso sexual, há alguns sintomas infantis também frequentes em situação de alta litigância entre os pais. "A SAP raramente existe na sua forma pura. Crianças que foram submetidas a traumas psicológicos oriundos do divórcio de seus pais podem sofrer de uma série de outros sintomas, frequentemente não correlacionados com a SAP" (Gardner, 1998, p. 364). Por exemplo, a agitação psicomotora, a atividade masturbatória, a agressividade, o baixo rendimento escolar, os distúrbios do sono, a angústia e a depressão podem ser utilizados pelos profissionais para uma correlação precipitada e direta, confirmando ocorrência de abuso. Para a psicanálise, não se pode estabelecer uma correlação tão simples entre o sintoma e a causa. De fato existem sintomas muito particulares e comuns em crianças que passam por situação sexualmente abusiva, mas estes aparecem mais bem definidos e intensos em abuso sexual com aproximação violenta, dolorosa e repetida, 
o que, por outro lado, não é o caso de grande parte dos abusos, por serem atos libidinosos e, portanto, mais tênues ao se investigar.

Em um caso de suspeita de abuso sexual por parte da mãe, concluiu-se ser denúncia fabricada pelo pai em função de uma retaliação. A psicóloga procurada pelo pai durante o processo emitiu documento unilateral sem chamá-la para entrevistas, confirmando o abuso de sua parte.

A profissional descreveu uma criança medrosa e insegura, com medo de afastar-se do pai e concluiu que tal sintoma devia-se ao trauma pela situação abusiva a que ela fora exposta, pois crianças abusadas podiam ficar amedrontadas.

No entanto, o indício de abuso colhido pela profissional revelou mais tarde ser uma resposta da criança ao entorno familiar paterno que passou a mudar o tratamento em relação à criança depois do resultado do laudo psicológico. Passaram a cercear a criança, mimá-la e impedi-la de fazer coisas a que já estava acostumada. Não podia brincar livremente e era tratada como um bebê. Passaram a tratá-la indicando que tudo o que fazia oferecia risco e a criança respondeu apresentado medo.

Se a psicóloga tivesse chamado a mãe, teria percebido a diferença de sua apresentação na presença desta, teria assim concluído que o medo era uma resposta às fantasias e demandas paternas. A correlação direta entre sintoma e causa pode levar a preencher as lacunas durante uma avaliação, as quais requerem um tempo mais longo para que possam ser respondidas. Apreensão das teorias de abuso e da SAP da forma imaginária podem levar ao encaixe dos casos clínicos em modelos prontos. Para a psicanálise, o diagnóstico se dá a partir da transferência; com poucas entrevistas, tende-se a priorizar o relato verbal em detrimento da posição subjetiva, levando a esse tipo de engano.

A teoria da SAP atenta para a necessidade de criação de protocolos para avaliações sobre abuso sexual, com estabelecimento de padrões mínimos. Aspectos presentes na teoria da SAP podem balizar estudos para detectar falsas alegações de abuso sexual e, portanto, contribuir para 
métodos de diagnóstico diferencial das alegações. É necessário trazer inovações às técnicas, mais estudos e explanações sobre os mecanismos psíquicos envolvidos nas falsas alegações. Neste exemplo, apresentam-se algumas crenças importantes que criam ainda generalizações no meio profissional a respeito do assunto. Por exemplo, "toda alegação infantil é verdadeira pois criança não mente" ou "toda verbalização detalhada indica ocorrência de abuso". A criança considerada "vítima" inocente que precisa de proteção, não pode ser questionada. Assim, provoca identificações enganosas por parte dos profissionais, antes mesmo que se inicie um estudo. A psicanálise revela que a criança não é um sujeito inocente, é um ser sexual, pode mentir deliberadamente, confundir fantasias detalhadas com realidade, apresentar fantasias incestuosas e uma sexualidade ativa, como a masturbação.

Os motivos que levam a uma falsa alegação devem ser explanados, pois, se retaliativa ou não, revela um diferencial quanto aos efeitos na criança e pode fornecer dados quanto à parentalidade, importantes de serem trazidos no estudo pericial. Muitas vezes os profissionais limitam seu trabalho a responder se houve ou não o referido abuso, deixando de lado uma investigação mais criteriosa quanto aos motivos para a falsa alegação, os efeitos na criança e no acusado. Um estudo mais detalhado pode ajudar numa melhor regulação da situação familiar, bem como diminuir o risco de novas falsas alegações. A análise do que gerou a falsa alegação é um procedimento importante à elucidação da demanda do Juízo, por permitir o diagnóstico diferencial. É possível que essa elucidação mais detalhada traga aspectos da verdade subjetiva dos envolvidos, que permanece oculta, gerando novas falsas alegações e permitindo talvez uma ressignificação da alegação de abuso, que pode ter sido cristalizada na subjetividade dos envolvidos. Quando a falsa alegação por motivos retaliativos pode ser identificada pela equipe, permite promover um recuo na posição do alienador, refletindo-se na criança e restituindo certa dignidade a quem foi acusado. 
O conteúdo em torno do qual gravita uma acusação deve receber um exame minucioso do profissional. Esses dados permitem uma investigação mais criteriosa para a realização do diagnóstico diferencial. Certa mãe acusou o pai de abusar sexualmente da filha. Verificou-se que, na época, o casal parental trocava acusações mútuas. O pai, por sua vez, acusou a mãe de mudar constantemente de namorado expondo a filha a riscos. Essa troca de acusações resultou em três acusações contra o pai, dentre elas uma de abuso sexual. A mãe acusava ao pai de dar álcool e muitos doces à criança, que era diabética. A acusação revelou-se falsa. A genitora era filha adotada em razão de ter sofrido negligência e maustratos por parte da sua mãe biológica, que falecera por overdose. Esta trabalhava como garota de programa, era alcoolista e mantinha a filha por dias trancada em casa sozinha.

O profissional, ao conhecer melhor cada definição abordada e suas nuanças, pode discernir as situações complexas, atuando de forma mais criteriosa. Quando se refere à definição da Lei brasileira, observa-se que esta inclui diferentes níveis e definições do que pode ser considerado uma alienação parental. Gardner enfatiza, com a teoria da SAP, o formato de campanha da alienação e a recusa da criança para que se possa utilizar o diagnóstico criado por ele. Sua teoria engloba uma quantidade menor de casos quando comparada com os casos que incluem-se na Lei brasileira, pois a SAP corresponde a casos mais persistentes e mais graves. Nota-se que o número de situações familiares que podem ser inclusas na tipificação da Lei de alienação parental ultrapassa as estatísticas de SAP previstas por Gardner, apesar da SAP estar inclusa na definição da Lei brasileira. No caso da definição da Lei brasileira, por compreender uma definição mais jurídica do que patológica, sendo portanto mais amplamente aplicável aos casos de litigância nas Varas de Família, haverá a necessidade de operadores mais versados sobre as questões psicológicas e peritos mais dedicados em cada caso particular.

Se por um lado a Lei dá mais poder para o magistrado determinar sobre questões psicológicas, por outro, a formação do profissional não 
inclui o conhecimento específico na área de Psicologia. A Lei vem reafirmar a necessidade de uma formação na área da saúde mental ao juiz de família, uma vez que suas determinações ou até mesmo a ausência delas surtem importantes efeitos subjetivos nos envolvidos, contribuindo para regular ou aumentar o que é disfuncional na família. Nesse sentido, (2009) explicita como a maior proximidade entre a equipe técnica e os operadores do Direito pode ajudar nas decisões mais afinadas:

...laudos e pareceres não devem ser a única comunicação com o magistrado e os operadores de Direito. Sob o risco de anular todo um esforço de resgatar a convivência, a equipe deve procurar outros meios de interlocução com os outros profissionais. Assim, supõe-se que o hiato entre o trabalho interdisciplinar e 0 cenário da audiência judicial possa ser diminuído.

Uma outra problemática importante a ser discutida em casos de programação ou de SAP deve-se a um tipo particular de abuso físico, muito pouco encontrado na literatura nacional. No intuito de alienar o outro genitor, o programador pode forjar ou induzir algum tipo de doença, aumentar sintomas, ministrar remédios desnecessários, deixar de passar orientações importantes, remédios e cuidados ao outro genitor, forçar internações médicas, buscar apoio em atestados médicos para impedir visitas a fim de demonstrar que a criança foi negligenciada durante o período em que esteve com o outro genitor.

Alguns alienadores costumam explorar questões de saúde física da criança, gerando muitas vezes falsas alegações de maus-tratos, negligência ou algum tipo de abuso físico contra o genitor alienado. Tais acusações são comuns de serem feitas depois do retorno das visitas ou das férias, quando a criança permaneceu com o outro genitor. Elas estão ligadas a uma explicação de que o genitor não cuida direito do filho, o expõe a riscos, é violento ou prejudicial à criança. Um genitor pode deixar de informar o outro a respeito de medicamentos importantes a serem administrados à criança para utilizar a piora em seu estado, durante as visitas ou férias, como prova de sua inadequação nos cuidados parentais. 
Um pai, depois de devolver seu filho de dois anos muito bem disposto na casa da genitora, foi surpreendido pela entrada da criança no ambulatório logo na sequência da devolução conforme observou o horário de entrada no hospital na ficha do filho. A mãe alegara que o filho corria risco de vida, pois o pai tinha administrado medicamento sabendo ele ser alérgico, comprovando dessa forma a inadequação paterna pelos perigos aos quais expunha a criança. Medicamentos fortes foram administrados à criança no hospital e tais evidências foram utilizadas pela mãe no processo. Ao conversar com os médicos, estes afirmaram que na data a criança estava bem de saúde, apresentando apenas algumas pintinhas vermelhas pelo corpo que a mãe dissera ser alergia a medicamento. $O$ pai havia observado que, no dia da visita, a criança fora entregue pela mãe com calça e blusa de manga comprida num dia de extremo calor, o que Ihe causou estranheza. Ao tirar a roupa da criança, verificou que antes mesmo de pegar a criança para a visita já havia tais pintinhas. No contato com o pediatra, este confirmou que, dois dias antes da visita paterna, a mãe havia levado a criança para tomar vacina, estando ciente de que tais pintinhas se deviam a uma leve reação.

Outro genitor tentava reiteradamente pegar sua filha para as visitas, mas a mãe sempre saía antes com a criança. Certa vez, chegando mais cedo, viu a genitora colocando-a no carro para sair. Ao tentar impedir a saída da mãe com a filha, a genitora atropelou o pai com o carro e fugiu. Foi parada pela polícia por estar dirigindo na contramão, quando o pai chegou ao mesmo local. A genitora disse ao policial estar fugindo do pai em razão das ameaças feitas por ele. Quando o pai explicou que tentava pegar a filha para a visita e que a mãe o impedia, o policial encaminhou todos à delegacia. A genitora afirmou que não permitia a visita naquele dia pois tentava levar sua filha doente ao hospital. Afirmou que, se o policial a impedisse de fazê-lo, seria culpado pelos danos à saúde da criança.

O policial optou por acompanhá-los ao hospital público para averiguar se a criança estava mesmo doente e impedida de realizar as 
visitas paternas. A mãe dentro da viatura abriu as janelas do carro em dia de inverno de intenso frio e chuva, colocou a cabeça do bebê para fora do carro até chegar ao hospital na esperança de que fosse detectada alguma doença que impedisse a visita ao pai. O policial acionou o Conselho Tutelar, por presenciar a cena e por se recusar a deixar a mãe sair da delegacia com a criança.

Durante um processo de visitas, a genitora saía de casa com o filho nos momentos de visita do pai. Quando a juíza fixou multa de três mil reais a cada visita frustrada, a mãe permitiu que o pai pegasse a criança, que disse: Eu só vim hoje porque senão minha mãe ia tomar uma multa enorme e podia ser presa. No dia da primeira visita, o pai levou a criança ao parque, onde ela se arranhou brincando e o pai fez um curativo no filho no ambulatório. A mãe, por sua vez, fez Boletim de Ocorrência com exame de corpo delito. O filho disse ao pai: Quando você me deixou em casa, a mamãe ficava querendo mexer no meu machucado. Ela tirou a casquinha com a unha e sangrou. E falei para ela não mexer pois já tinha colocado remédio, doía, mas disse que precisava tirar foto porque você não cuida direito de mim. Ela fez um montão de fotos e a gente ficou a noite toda sentados na delegacia.

Não fosse o momento cultural propício ao estudo de questões altamente complexas como as falsas alegações e a SAP, talvez uma recente situação exposta na mídia não tivesse sido esclarecida. No Espírito Santo, em 22/07/11, foi publicada uma matéria (ANEXO B) na qual, diante de um processo de disputa de guarda entre pai e mãe, a genitora teria molestado a própria filha para simular abuso sexual por parte do exmarido, de forma a obter vantagens no processo de guarda. A criança teria espontaneamente contado ao delegado e a uma médica, antes mesmo que o genitor soubesse, o abuso físico infligido pela mãe. Essa situação, não fosse a novidade do tema, poderia ter passado despercebida e ensejar uma falsa alegação contra o pai, por parecer um tanto fantasiosa. De acordo com Parnell (1998, p.40, citado por Amendola, 2009), "as falsas alegações abrangem a fabricação intencional, crença 
equivocada de que a criança foi abusada e más interpretações ou distorções. Os pais podem induzir sinais físicos do trauma sexual para provar suas alegações de abuso sexual" (p.124)

Tais equívocos por parte dos profissionais começam a ser alvo de exames mais críticos chegando a envolver até mesmo processos de indenização. Em 2010 (ANEXO C):

O Tribunal de Justiça de São Paulo condenou a Prefeitura de São José dos Campos (97 km de São Paulo) a indenizar em $\mathrm{R} \$ 70$ mil os pais acusados injustamente de abuso sexual contra a filha. O caso envolveu a ação de integrantes do Conselho Tutelar, que confundiram alergia com estupro, separaram a menina da família e a mandaram para um abrigo de menores, sem que os acusados fossem ouvidos.

...O médico contou que havia um quadro de irritação vaginal e que ele mesmo havia informado a escola sobre a situação.

.... Inconformada com a atitude do Conselho Tutelar, a família ingressou com ação de indenização. Pediu $R \$ 70$ mil pelo dano moral sofrido com a separação temporária da criança e a sua internação em um abrigo.

Atitudes precipitadas por parte dos profissionais levam em conta justificativas que cada vez mais são questionadas, quanto aos danos secundários, porque não irreparáveis, a tais famílias. Em relação ao ocorrido sustentou a Procuradoria do Município: "É melhor assumir os riscos do que ignorar a possibilidade da menor continuar sofrendo abusos, e, se a denúncia não restou comprovada, o Conselho Tutelar não pode ser condenado por cumprir seu dever legal". A nova Lei de alienação parental lança maiores discussões quanto a casos deste tipo: por que não pensar que a criança foi brutalmente alienada de seus pais?

\subsection{EM DIREÇÃO A NOVOS HORIZONTES}

Os altos níveis de violência nas famílias que passam por divórcio desafiam as atuações profissionais mais preparadas e os métodos de intervenção existentes. Estando a criança envolvida no grupo familiar, passa a ser dever do Estado averiguar possíveis prejuízos ou danos e zelar pela proteção do menor. Muitas vezes os operadores encontram-se numa 
situação delicada, por temerem que seu posicionamento ou determinação possam gerar efeitos contrários ao esperado. Essa observação evidencia quão desamparadas se encontram as famílias desfeitas e os operadores do Direito diante da pouca estrutura para a realização do trabalho. Tal observação vem a marcar a urgência de uma melhor estrutura no Judiciário e o apoio de programas que lidem com níveis mais amplos da problemática. Inegável a necessidade de acompanhamento dessas famílias, pela criação de outras formas de serviços.

Em Nova York, os pais que passam por separação devem frequentar cursos e orientação quinzenais sobre como lidar com os conflitos do pósdivórcio, para minimizar o impacto nos filhos. Alguns desses programas, como o Breakthrough Parenting, têm objetivo de ajudar pais a lidar com o litígio no pós-divórcio, inclusive prevenindo contra a SAP. Apesar de a psicanálise indicar o impossível que existe na educação por reconhecer a dimensão do desejo que está para além de uma prática educativa, podese reconhecer neste tipo de programa social, o reconhecimento dos efeitos danosos que pode ter ter uma separação conjugal e a necessidade do apoio do Estado diante da falência das funções parentais.

A complexa retomada dos laços parento-filiais que foram rompidos conta com programas específicos para tratar essas situações familiares. 0 programa Families Bridges tem o objetivo de tratar crianças que rejeitam um dos genitores e mantê-las afastadas dos conflitos conjugais após a separação. Alguns desses serviços de reintegração, como The Rachel House e Overcoming Barriers Family Camp, propõem um acampamento com atividades orientadas por especialistas que acompanham a família para reconectar relações.

Nos EUA existe uma forma inovadora de resolução de conflitos de alta litigância denominada Parenting Coordination ( $P C)$. O PC é um processo centrado na criança, não confidencial, para famílias em que a mediação não é apropriada devido aos altos níveis de conflito ou violência doméstica, incluindo a SAP. Os terapeutas são treinados e designados 
pela instância judicial para trabalhar famílias selecionadas pelo magistrado.

Embora a mediação tenha sido apontada na modernidade como importante instrumento, que permite maior alcance de sucesso na resolução das disputas, não é indicada nas famílias que passam por alta litigância. No entanto, em razão do agravamento dos conflitos não raramente levar à SAP, a mediação pode ser indicada nos casos em que os conflitos não estão tão intensos.

A abordagem de Gardner traz um recorte visando intervenções possíveis em casos refratários ao sistema jurídico e a outros tipos de intervenções mais conhecidos. A determinação de obrigatoriedade de terapia para tratar a rejeição, em casos de SAP, muitas vezes não é aconselhável, pois dificilmente o guardião e o filho aceitarão tratar-se. Quando aceitam, normalmente se observa aliança com o terapeuta de forma a deixar o problema intocado, burlando o objetivo de tratar. Se o terapeuta mostra-se eficiente em abordar a problemática, tais pacientes tornam-se resistentes e abandonam o tratamento. Por esses motivos, muitas vezes a ordem do juiz para tratar é uma indicação impotente. Por outro lado, níveis pouco pronunciados de SAP podem obter algum sucesso no tratamento.

Gardner afirma que a terapia familiar indicada para tratar a SAP deve ser breve, pois se diferencia da terapia convencional, na qual o paciente é levado a ter insight a respeito da sua psicodinâmica. O objetivo do tratamento, desinstalar a SAP, apenas sucede por estar intimamente ligado ao sistema judicial e por envolver todos os membros da família. A figura do profissional, o perito-terapeuta, fornece experiências concretas aos seus pacientes. Em contato contínuo com o juiz, ele passa a evolução do tratamento, obtendo o apoio de sua autoridade do tribunal, nos momentos de resistência. O terapeuta promove aproximações, progride nas visitas, trabalha para amenizar a animosidade e a distorção da criança a respeito da imagem do genitor alienado. Segundo Gardner, a associação entre $o$ perito e o juiz torna-se indispensável ao sucesso desta 
abordagem. Refere Sauber (2006): "Deve ser apontado que o sistema judiciário tem poder e influência, até mesmo maior que a equipe de saúde mental para aliviar este distúrbio mental" (p.13). No entanto, de acordo com a resolução do CFP 8/2010, que trata de estabelecer maiores distinções entre as funções de terapeuta, assistente técnico e perito, poder-se-ia pensar que essa figura híbrida de terapeuta-perito proposta por Gardner esteja em desacordo com a nova resolução da profissão.

Em casos de inversão de guarda, quando existe o rompimento completo das relações junto a uma forte rejeição do genitor, Gardner propõe que a mudança seja feita através de famílias de transferência. Esse programa em fases visa possibilitar gradualmente a convivência da criança com o genitor rechaçado, por meio de sua remoção da casa do genitor alienador para a casa de um terceiro neutro, até que a criança passe a aceitar o convívio com o novo genitor guardião de forma mais tranquila e segura.

A criação de outras Varas especiais da violência, como no Fórum da Barra Funda, em São Paulo, Capital, pode vir a fornecer uma estrutura mais adequada e especial aos atendimentos de casos mais complexos, contando com profissionais altamente capacitados.

A criação de novos dispositivos sociais e jurídicos pode ajudar a regular os conflitos de alta litigância no pós-divórcio, que constantemente desencadeiam a SAP e outros tipos de violência familiar. São situações que se revelam complexas em sua regulação, necessitando de diferentes aparatos, programas e dispositivos que se complementem para serem administradas ou reguladas de uma forma mais eficaz. Isso porque se observa que a SAP está ligada intimamente com as leis de um país, os papéis sociais, a forma de os tribunais lidarem com as questões de guarda e convivência, entre outros. O genitor alienador pode recuar na programação depois de uma ação judicial que vise regular o abuso do Poder Familiar. O programador lapida seu discurso conforme a direção do processo, fazendo um mimetismo que mascara a alienação e evita 
sanções. Tal observação marca a importância de uma atuação mais clara e alinhada por parte dos profissionais.

O discurso das partes sempre encobre a posição subjetiva das partes, razão pela qual o diagnóstico deve partir não dos fenômenos, da fala e do comportamento, mas da posição subjetiva do sujeito. Nos casos mais resistentes à intervenção, assim que findado o processo, retoma-se automaticamente a programação sistemática. Não apenas as questões sociais devem ser alvo de exames, mas a atuação profissional que leva em consideração as características de cada família, no momento da adoção de medidas para regular o poder da forma mais adequada a cada situação. 


\section{REFERÊNCIAS ${ }^{18}$}

Amendola, M. F. (2009). Crianças no labirinto das acusações: falsas alegações de abuso sexual. Curitiba: Juruá.

Barreiro, C. A. (2010). Guarda compartilhada: um caminho para inibir a alienação parental. Recuperado em 17 de julho de 2011, de http://www.ibdfam.org.br/?artigos\&artigo $=574$

Bernet, W. (no prelo). Falsas denúncias e o diagnóstico diferencial das alegações de abuso sexual (T. Brockhausen, trad.). Psicologia Revista.

Bernet, W. (2006). Sexual Abuse Allegations in the context of child custody disputes. In R. Gardner; S. Sauber; D. Lorandos (Eds.), The international handbook of parental alienation syndrome: conceptual, clinical and legal considerations (pp. 242-263). Springfield, IL: Charles C Thomas.

Brandão, E.P. (2009). Por uma ética e política da convivência: um breve exame da "Síndrome de Alienação Parental" à luz da genealogia de Foucault. Recuperado em 15 de julho de 2011, de http://www.ibdfam.org.br/?artigos\&artigo $=555$

Brito, L. M. T. (2004). Guarda conjunta: conceitos, preconceitos e prática no consenso e no litígio In R. C. Pereira (Coord.), Afeto, ética, família e o novo código civil (pp.355-367). Belo Horizonte: Del Rey.

Brockhausen, T. (2011a, no prelo). Falsas alegações de abuso sexual: o contexto do trabalho do psicólogo. Psicologia Revista.

${ }^{18}$ De acordo com o estilo APA - American Psychological Association 
Brockhausen, T. (2011b, no prelo). Alienação parental. Psicologia Ciência e Profissão: Diálogos.

Bruno, Denise Duarte.(2007). Abrindo os olhos para verdadeiros relatos e falsas memórias. In: M. B. Dias (Org.), Incesto e alienação parental: realidades que a justiça insiste em não ver (pp. 64-73). São Paulo: Revista dos Tribunais.

Calçada, A. (2005). Falsas acusações de abuso sexual: parâmetros iniciais para uma avaliação. In APASE (Org.), Guarda compartilhada: aspectos psicológicos e jurídicos (pp. 123-144). Porto Alegre: Equilíbrio.

Cama de Proscuto. (n.d.). In Wikipidia. Recuperado em 18 de julho de 2011, de http://pt.wikipedia.org/wiki/Procusto

Salvain, P. (1996). Passagem ao ato. In P. Kaufmann (Ed), V. Ribeiro e M.L.X. de A. Borges, trads., Dicionário enciclopédico de psicanálise: o legado de Freu e Lacan (p.55). Rio de Janeiro: Jorge Zahar Editor.

Cavaggioni, A.; Calçada, A., \& Neri, L. (2001). Falsas acusações de abuso sexual: o outro lado da história. Rio de Janeiro: OR.

Comel, D. D. (2003). Do Poder Familiar. São Paulo: Editora Revista dos Tribunais. 
Constituição da República Federativa do Brasil. (1988, 05 de outubro). Recuperado em 6 de novembro de 2006, de http://www.planalto.gov.br/ccivil_03/constituicao/constitui\%C3\%A7ao. htm

Cruz, D. A Síndrome da alienação parental, escudada pelo Poder Judiciário. (2010). IBDFAM (Instituto Brasileiro de Direito de Família). Recuperado em 15 de julho de 2011, de http://www.ibdfam.org.br/?artigos\&artigo $=681$

Darnall, D. (1998). Divorce casualties: protecting your children from parental alienation. New York:Taylor.

Decreto-Lei n. 2.848, de 7 de dezembro de 1940. (1940, 31 de dezembro). Código Penal. Recuperado em 16/07/2011, de http://www.planalto.gov.br/ccivil_03/Decreto-Lei/Del2848.htm

Dias, M. B. (2008) Síndrome da alienação parental. O que é isso? In. APASE (Org.). Síndrome da alienação parental e a tirania do guardião: aspectos psicológicos, sociais e jurídicos (pp. 14-26). Porto Alegre: Equilíbrio.

Duarte, M. Alienação parental: comentários iniciais à Lei 12.318/2010. (2010). IBDFAM (Instituto Brasileiro de Direito de Família). Recuperado em 15 de julho de 2011, de http://www.ibdfam.org.br/?artigos\&artigo $=697$

Dunker, C.I.L. A desautorização da mãe pelo pai. (2008). Revista pais e filhos. Recuperado em 25 de agosto de 2011, de http://stoa.usp.br/chrisdunker/files/1871/10611/2008+- 
+A+Desautoriza $\%$ C3\%A7\%C3\%A3o+da+M\%C3\%A3e+pelo+Pai+-

+Revista+Pais+e+Filhos.pdf

Dunker, C.I.L (2001). Clínica, linguagem e subjetividade. In Distúrbios da comunicação. 12, 39-61.

Figueredo, F.; Alexandridis, G. (2011). Alienação parental. São Paulo: Saraiva.

Fonseca, P. M. P. C. Síndrome de alienação parental. (n.d.). Recuperado em 13 de julho de 2011, de http://www. priscilafonseca.com.br/?id=59\&artigo $=6$

Freud, S. (1996). A psicoterapia da histeria. In Edição standard das obras psicológicas completas de Sigmund Freud. (J. Salomão, trad., Vol. 2, pp. (271-316). Rio de Janeiro: Imago. (trabalho original publicado em 1895).

Freud, S. (1996). Sobre a psicoterapia. In Edição standard das obras psicológicas completas de Sigmund Freud. (J. Salomão, trad., Vol. 7, pp.241-254). Rio de Janeiro: Imago. (trabalho original publicado em 1905 [1904]).

Freud, S. (1996). O método psicanalítico de Freud. In Edição standard das obras psicológicas completas de Sigmund Freud. (J. Salomão, trad., Vol. 7, pp.233-240). Rio de Janeiro: Imago. (trabalho original publicado em 1904 [1903]). 
Freud, S. (1996). Fragmento da análise de um caso de histeria. In Edição standard das obras psicológicas completas de Sigmund Freud. (J. Salomão, trad., Vol. 7, pp.15-116). Rio de Janeiro: Imago. (trabalho original publicado em 1905 [1901]).

Freud, S. (1996). Três ensaios sobre a teoria da sexualidade. In Edição standard das obras psicológicas completas de Sigmund Freud. (J. Salomão, trad., Vol. 7, pp. (119-231). Rio de Janeiro: Imago. (trabalho original publicado em 1905a).

Freud, S. (1996). Tratamento psíquico (ou anímico) In Edição standard das obras psicológicas completas de Sigmund Freud. (J. Salomão, trad., Vol. 7, pp. 267-288). Rio de Janeiro: Imago. (trabalho original publicado em 1905b).

Freud, S. (1996). A dinâmica da transferência. In Edição standard das obras psicológicas completas de Sigmund Freud. (J. Salomão, trad., Vol. 12, pp.109-133). Rio de Janeiro: Imago. (trabalho original publicado em 1912).

Freud, S. (1996). A história do movimento psicanalítico. In Edição standard das obras psicológicas completas de Sigmund Freud. (J. Salomão, trad., Vol. 14, pp. 15-73) . Rio de Janeiro: Imago. (trabalho original publicado em 1914a).

Freud, S. (1996). Introdução ao narcisismo. In Edição Santard das obras psicológicas completas de Sigmund Freud. (J. Salomão, trad. Vol. 14, pp. 85-122). Rio de Janeiro: Imago. (trabalho original publicado em 1914b)

Freud, S. (1996). Observações sobre o amor transferencial. In Edição standard das obras psicológicas completas de Sigmund Freud. (J. Salomão, trad., Vol. 12, pp.19-116). Rio de Janeiro: Imago. (Trabalho original publicado em 1915a). 
Freud, S. (1996). Os instintos e suas vicissitudes. In Edição standart brasileira das obras psicológicas completas de Sigmund Freud (J. Salomão, trad., Vol.14, pp. 116-144). Rio de Janeiro: Imago. (trabalho original publicado em 1915b).

Freud, S. (1996). Conferência 23: Os caminhos da formação dos sintomas. In Edição standart brasileira das obras psicológicas completas de Sigmund Freud (J. Salomão, trad., Vol. 16, pp. 361-378). Rio de Janeiro: Imago. (trabalho original publicado em 1917 [1916a]).

Freud, S. (1996). Conferência 28: Terapia Analítica. In Edição standart brasileira das obras psicológicas completas de Sigmund Freud (J. Salomão, trad., Vol. 16, pp. 449-464). Rio de Janeiro: Imago. (trabalho original publicado em 1917 [1916b]).

Freud, S. (1996). "Uma criança é espancada" uma contribuição ao estudo da origem das perversões sexuais. In Edição standart brasileira das obras psicológicas completas de Sigmund Freud (J. Salomão, trad., Vol. 17, pp. 192-218). Rio de Janeiro: Imago. (trabalho original publicado em 1919).

Freud, S. (1996). Psicologia de grupo e análise do ego. In Edição standart brasileira das obras psicológicas completas de Sigmund Freud (J. Salomão, trad., Vol. 18, pp. 77-154). Rio de Janeiro: Imago. (trabalho original publicado em 1921).

Freud, S. (1996). A Organização Genital Infantil: uma interpolação na teoria da sexualidade. In Obras psicológicas completas de Sigmund Freud: Edição Standard Brasileira, (Vol. 19, pp.179-188). Rio de Janeiro : Imago. (trabalho original publicado em 1923).

Freud, S. (1996). Inibições, sintomas e ansiedade. In Edição standart brasileira das obras psicológicas completas de Sigmund Freud (J. Salomão, trad., Vol. 20, pp.79-171.). Rio de Janeiro: Imago. (trabalho original publicado em 1926 [1925]). 
Freud, S. (1996). A negativa. In Edição standart brasileira das obras psicológicas completas de Sigmund Freud (J. Salomão, trad., Vol. 19, pp. 263-272). Rio de Janeiro: Imago. (trabalho original publicado em 1925).

Freud, S. (1996). Mal-estar na civilização. In Edição standart brasileira das obras psicológicas completas de Sigmund Freud (J. Salomão, trad., Vol. 21 , pp.65-148). Rio de Janeiro: Imago. (trabalho original publicado em 1930 [1929]).

Freud, S. (1996). Novas conferências introdutórias sobre psicanálise. In Edição standart brasileira das obras psicológicas completas de Sigmund Freud (J. Salomão, trad., Vol. 22, pp.13-180). Rio de Janeiro: Imago. (trabalho original publicado em 1933 [1932]).

Freud, S. (1996). Análise terminável e interminável. In Edição standart brasileira das obras psicológicas completas de Sigmund Freud (J. Salomão, trad., Vol. 23, pp.231-270). Rio de Janeiro: Imago. (trabalho original publicado em 1937).

Furniss, Tilman. (1993). Abuso Sexual da Criança: uma abordagem multidisciplinar. Porto Alegre: Artes médicas.

Gardner, R. A. (1998). The parental alienation syndrome: a guide for mental health and legal professionals. (2nd ed.). Cresskill, NJ: Creative Therapeutics.

Gardner, R. A. (2006). Introduction. In R. Gardner; S. Sauber; D. Lorandos (Eds.), The international handbook of parental alienation syndrome: conceptual, clinical and legal considerations, (pp. 242-263). Springfield, IL: Charles C Thomas. 
Gardner, R. A. (2003). The Parental Alienation Syndrome (PAS): Past, Present and Future. In Parental Alienation Syndrome: An Interdisciplinary Challenge for Professionals Involved in Divorce, (pp.89-123). Frankfurt, Alemanha: Verlag für Wisseschaft und Bildung

Guazzelli, Mônica. (2007). A falsa denúncia de abuso sexual. In: M. B. Dias (Org.), Incesto e alienação parental: realidades que a justiça insiste em não ver (pp. 112- 139). São Paulo: Revista dos Tribunais.

Hironaka G. M. F. N. \& Mônaco, G. F. C. Síndrome de alienação parental. (2010). IBDFAM (Instituto Brasileiro de Direito de Família). Recuperado em 09 de abril de 2010, de http://www.ibdfam.org.br/?artigos\&artigo $=589$

Jorge, M. R. (1996). Diagnóstico e classificação em psiquiatria. In O.P. Almeida, L. Dractu \& R. Laranjeira (Org.), Manual de psiquiatria. (pp.22-31). São Paulo: Guanabara Koogum.

Kopetski, L.M; Rand, C., Rand, R. (2006). Incidence, gender, and false allegations of child abuse: data on 84 parental alienation syndrome cases. In In R. Gardner; S. Sauber; D. Lorandos (Eds.), The international handbook of parental alienation syndrome: conceptual, clinical and legal considerations (pp. 65-89). Springfield, IL: Charles C Thomas.

Julien, P. (2000). Abandonarás teu pai e tua mãe. Rio de janeiro: Companhia de Freud. 
Lacan, J. (1987). Os complexos familiares na formação do indivíduo: ensaio de análise de uma função em psicologia. (trads. Jorge, M.A.C e Jr, P.M da S). Rio de Janeiro: Jorge Zahar Editor.(trabalho original publicado em 1938).

Lacan, J. (1998). O estádio do espelho como formador da função do eu: tal como nos é revelada na experiência psicanalítica. In Escritos (trad. V. Ribeiro, pp.96-103).Rio de Janeiro: Jorge Zahar Editor. (trabalho original publicado em 1949).

Lacan. J. (1998). A direção do tratamento. In J. Lacan. Escritos. (pp. 633641). Rio de Janeiro: Jorge Zahar Editor (trabalho original publicado em 1958).

Lacan, J. (1995). O Seminário, Livro 4: As relações de objeto. (D.D. Estrada, trad., A. Harari, rev. técnica) Rio de Janeiro: Jorge Zahar Editor. (trabalho original publicado em 1956 [1957]).

Lacan, J. (1999). O seminário, livro 5: as formações do inconsciente. (V. Ribeiro, trad., M.A.Vieira, rev. técnica) Rio de Janeiro: Jorge Zahar Editor.(trabalho original publicado em 1957 [1958]).

Lacan, j. (1998). A ciência e a verdade. In Escritos (pp. 869-892). Rio de Janeiro: Jorge Zahar Editor. (trabalho original publicado em 1966[1965].

Lacan. J. (2008). O Seminário, livro 16: de um outro ao Outro. Rio de Janeiro: Jorge Jahar Editor. (trabalho original publicado em 1968 [1969]). 
Lacan, J. (1985). O Seminário, Livro 11, Os Quatro Conceitos Fundamentais da Psicanálise.(2 ed.) Rio de Janeiro: Jorge Zahar Editor. (trabalho original publicado em 1965 [1964]).

Lacan, J. (abril/1998). Duas notas sobre a criança. Opção Lacaniana, Revista Brasileira Internacional de Psicanálise, 21, 5-6.

Lacan, J. (1969-70/1992). O Seminário, Livro 17, O Avesso da Psicanálise. Rio de Janeiro: Jorge Zahar Editor.

Lacan, J. (1998) Escritos, Rio de Janeiro, Jorge Zahar.

Lacan, j. (1998). Observações sobre o relatório de Daniel Lagache. In j. Lacan. Escritos.(pp.653-691). Rios de Janeiro Jorge Zahar Editor. (trabalho original pubicado em 1960a).

Lacan, j. (1998). A subversão do sujeito e a dialética do desejo no inconsciente freudiano. In J. Lacan. Escritos. (pp.807-842). Rio de Janeiro Jorge Zahar Editor.(trabalho original pibicado em 1960b).

Lacan. J. (1992). O Seminário, livro 8: A transferência. Rio de Janeiro: Jorge Jahar. (trabalho original publicado em 1960/1961).

Lacan, J. (1992). O Seminário, livro 17: O avesso da psicanálise. Rio de Janeiro: Jorge Zahar. (Trabalho original publicado em 1969/1970).

Lacan, J. (1992). O Seminário, livro 2: O eu na teoria do Freud e a técnica da psicanálise. Rio de Janeiro: Jorge Zahar. (Trabalho original publicado em 1955[1954]/1970). 
Lacan, J. (1982). O Seminário, livro 20: Mais, ainda. Rio de Janeiro: Jorge Zahar Editor. (trabalho original publicado em 1972 [1973]).

Lago, V. M., \& Bandeira, D. R. (2009). Psicologia e as demandas atuais do direito de família. Psicol. cienc. prof. 29(2). Disponível em $<$ http://pepsic.bvsalud.org/scielo.php?script=sci_arttext\&pid=S141498932009000200007\&lng=pt\&nrm=iso >. Recuperado em 15 mar. 2011.

Lagrasta, C. N. (2009, 28 de agosto). Parentes: guardar ou alienar Síndrome da alienação parental.Resumos do III Congresso Paulista de Direito de Família. IBDFAM.

Laurent, E. (1997a). Alienação e separação I. In: Feldstein, R., Fink, B. \& Jaanus, M. (Orgs.), Para ler o seminário 11 de Lacan: os quatro conceitos fundamentais da psicanálise (pp. 52-57). Rio de Janeiro: Jorge Zahar.

Laurent, E. (1997b). Alienação e separação II. In: Feldstein, R., Fink, B. \& Jaanus, M. (Orgs.), Para ler o seminário 11 de Lacan: os quatro conceitos fundamentais da psicanálise (pp. 58-67). Rio de Janeiro: Jorge Zahar

Lei n. 5.925, de 1 de outubro de 1973. Retifica dispositivos da Lei $\mathrm{n}^{\circ}$ 5.869, de 11 de janeiro de 1973, que instituiu o Código de Processo Civil.(1973, 17 de janeiro). Recuperado em 17 de julho de 2011, de http://www6.senado.gov.br/legislacao/ListaNormas.action?numero=59 25\&tipo_norma $=$ LEI\&data $=19731001 \&$ link $=$ s

Lei n. 8.069, de 13 de julho de 1990. (1990, 16 de julho). Dispõe sobre o Estatuto da Criança e do Adolescente e dá outras providências. Recuperado em 17 de julho de 2011, de http://www.febem.sp.gov.br/files/pdf/eca.pdf 
Lei n.9.394, de 20 de dezembro de 1996. (1996, 23 de dezembro). Estabelece as Diretrizes e Bases da Educação Nacional. Diário Oficial da União, seção 1.

Lei 9.455 , de 1997. Define os crimes de tortura e dá outras providências. (1997, 7 de abril). Recuperado em 18 de julho de 2011, de http://www.planalto.gov.br/ccivil_03/leis/L9455.htm

Lei n. 10.406, de 10 de janeiro de 2002, (2002, 11 de janeiro). Institui o Código Civil. Recuperado em 16 de julho de 2011, de http://www.planalto.gov.br/ccivil_03/leis/2002/I10406.htm

Lei n.12.013, de 6 de agosto de 2009. Altera o art. 12 da Lei no 9.394, de 20 de dezembro de 1996, determinando às instituições de ensino obrigatoriedade no envio de informações escolares aos pais, conviventes ou não com seus filhos. (2009, 7 de agosto). Recuperado em 16 de julho de 2011, de http://www.planalto.gov.br/ccivil_03/_ato20072010/2009/lei/l12013.htm

Lei n. 12.318 , de 26 de agosto de 2010 . Dispõe sobre a alienação parental e altera o art. 236 da Lei no 8.069, de 13 de julho de 1990. (2010, 27 de agosto) Recuperado em 16 de julho de 2011, de http://www.planalto.gov.br/ccivil_03/_Ato20072010/2010/Lei/L12318.htm

Lei n. 12.398, de 28 de março de 2011, (2011, 29 de março). Acrescenta parágrafo único ao art. 1.589 da Lei no 10.406 , de 10 de janeiro de 2002 do Código Civil, e dá nova redação ao inciso VII do art. 888 da Lei $\mathrm{n}^{\circ}$ 5.869, de 11 de janeiro de 1973 do Código de Processo Civil, para estender aos avós o direito de visita aos netos. Recuperado em 16 
de julho de 2011, de http://www.planalto.gov.br/ccivil_03/_Ato20112014/2011/Lei/L12398.htm

Leite, E. de O. (1997). Famílias monoparentais: a situação jurídica de pais e mães separados e dos filhos na ruptura da vida conjugal. São Paulo: Editora Revista dos Tribunais.

Madaleno, R. (2002). Alguns apontamentos sobre guarda compartilhada. Recuperado em 18 de julho de 2011, de http://www.ibdfam.org.br/?artigos\&artigo=539

Nascimento, M. B. (2010, março). Alienação, Separação e travessia da fantasia. Opção Lacaniana on line nova série, 1(1), 1-15. Recuperado em 04 de outubro 2010, de www.opcaolacaniana.com.br

Oliveira, E. B. (2002). Direito de visitas dos avós aos netos. Revista Brasileira de Direito de Família, 13, 76-84.

Pellini, C. (2011, mar/abr). Alienação Parental: as dificuldades em torno da lei. (Entrevista ao CRP-SP). Psi Jornal de Psicologia de São Paulo CRP SP, 168, pp. 24-25.

Perez, E. L. (2010). Breves comentários acerca da lei de alienação parental. In M. B. Dias (Coord.), Incesto e alienação parental: realidades que a justiça insiste em não ver ( $2 \mathrm{a}$ ed. rev. ampl.). (pp. 61-94). São Paulo: Editora Revista dos Tribunais. 
Prates. A. L. B. (2006) Da fantasia de infância ao infantil na fantasia - a direção do tratamento na psicanálise com crianças. Tese de Doutorado, Instituto de Psicologia, Universidade de São Paulo, São Paulo.

Projeto de Lei n. 6.973. Introduz modificações no artigo 1.584 do Código Civil e acrescenta o Art. 233-A ao Estatuto da Criança e do Adolescente. (arquivado 2007). Recuperado em 17 de julho de 2011, de

http://www.camara.gov.br/proposicoesWeb/fichadetramitacao?idPropo sicao $=321786$

Ramos. S. (2007). Código da vida. São Paulo: Planeta Brasil.

Resolução CFP 10/2010, de 18 de junho de 2010, Institui a escuta psicológica de crianças e adolescentes envolvidos em situação de violência na rede de proteção.

Sauber, S. R. Pas as a family tragedy: roles of family members, professionals, and the justice system. In: Gardner, R.A., Sauber, S.R, Lorandos, D. (Eds.), The international handbook of parental alienation syndrome: Conceptual, Clinical and Legal Considerations, (pp. 12-32). Springfield, IL: Charles C Thomas.

Sauret, M. J. (1998, agosto). O Infantil e a Estrutura. Seminário de Psicanálise com crianças. EBP: São Paulo.

Shine, S. (2003). Abuso sexual de crianças. In Groeninga, G. C. \& Cunha, R. P. (Orgs.), Direito de família e psicanálise: rumo a uma nova epistemologia (pp.227-251). Rio de Janeiro: Imago. 
Silva, E. Z. M. (1999). Paternidade Ativa na Separação Conjugal. São Paulo: Juarez de Oliveira.

Simão, R. B. C. (2008). Soluções judiciais concretas contra a perniciosa prática da alienação parental. In APASE (Org.). Síndrome da alienação parental e a tirania do guardião: aspectos psicológicos, sociais e jurídicos (pp. 14-26). Porto Alegre: Equilíbrio.

Soler, C. (1997a). O sujeito e o Outro I. In Feldstein, R., Fink, B. \& Jaanus, M. (Orgs.), Para ler o seminário 11 de Lacan: os quatro conceitos fundamentais da psicanálise (pp. 31-41).Rio de Janeiro: Jorge Zahar.

Soler, C. (1997b). O sujeito e o Outro II. In Feldstein, R., Fink, B. \& Jaanus, M. (Orgs.), Para ler o seminário 11 de Lacan: os quatro conceitos fundamentais da psicanálise (pp. 42-51). Rio de Janeiro: Jorge Zahar.

Souza, R. P. R. (2008). A tirania do guardião. In. APASE (Org.), Síndrome da alienação parental e a tirania do guardião: aspectos psicológicos, sociais e jurídicos (pp. 14-26). Porto Alegre: Equilíbrio.

Souza, R. P. R. (2009). Síndrome de alienação parental e narcisismo. Monografia de Conclusão de Curso, Faculdade de Filosofia e Ciências Humanas, Universidade Federal de Minas Gerais, Belo Horizonte. Recuperado em 15 de julho de 2011, de http://www.psicologiananet.com.br/psicologia-forense-e-psicologiajuridica-pesquisa-cientifica-com-o-tema-sindrome-de-alienacaoparental-e-narcisismo/1953/ 
Strauss, M. (setembro 2000). Separar-se de seus pais. Revista Marraio: $A$ criança e o laço social, 0, 11-24.

Valas, P. (1991). O que é uma criança? In. J. Miller (Org.), A criança no discurso analítico, 1(2), 141-146.

Vives, J.M. (2009, julho). A pulsão invocante e os destinos da voz. Psicanálise e barroco, 7(1), 186-202.

Vorcaro, A. M. R. (1997). Sob a vigência da linguagem: uma aproximação à clínica psicanalítica de crianças. Tese de Doutorado, Psicologia Clínica, Pontifícia Universidade Católica de São Paulo, São Paulo. 
ANEXO A - Lei 12318/10

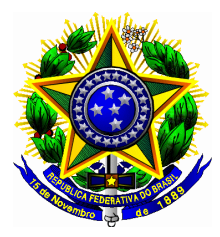

\section{Presidência da República}

Casa Civil

Subchefia para Assuntos Jurídicos

\section{LEI No 12.318, DE 26 DE AGOSTO DE 2010.}

Mensagem de veto

Dispõe sobre a alienação parental e altera o art. 236 da Lei no 8.069 , de 13 de julho de 1990.

O PRESIDENTE DA REPÚBLICA Faço saber que o Congresso Nacional decreta e eu sanciono a seguinte Lei:

Art. $1^{0}$ Esta Lei dispõe sobre a alienação parental.

Art. $2^{\circ}$ Considera-se ato de alienação parental a interferência na formação psicológica da criança ou do adolescente promovida ou induzida por um dos genitores, pelos avós ou pelos que tenham a criança ou adolescente sob a sua autoridade, guarda ou vigilância para que repudie genitor ou que cause prejuízo ao estabelecimento ou à manutenção de vínculos com este.

Parágrafo único. São formas exemplificativas de alienação parental, além dos atos assim declarados pelo juiz ou constatados por perícia, praticados diretamente ou com auxílio de terceiros:

I - realizar campanha de desqualificação da conduta do genitor no exercício da paternidade ou maternidade;

II - dificultar o exercício da autoridade parental;

III - dificultar contato de criança ou adolescente com genitor;

IV - dificultar o exercício do direito regulamentado de convivência familiar;

$\mathrm{V}$ - omitir deliberadamente a genitor informações pessoais relevantes sobre a criança ou adolescente, inclusive escolares, médicas e alterações de endereço;

VI - apresentar falsa denúncia contra genitor, contra familiares deste ou contra avós, para obstar ou dificultar a convivência deles com a criança ou adolescente;

VII - mudar o domicílio para local distante, sem justificativa, visando a dificultar a convivência da criança ou adolescente com o outro genitor, com familiares deste ou com avós.

Art. 3ㅇ A prática de ato de alienação parental fere direito fundamental da criança ou do adolescente de convivência familiar saudável, prejudica a realização de afeto nas relações com genitor e com o grupo familiar, constitui abuso moral contra a criança ou o adolescente e descumprimento dos deveres inerentes à autoridade parental ou decorrentes de tutela ou guarda.

Art. $4^{\circ}$ Declarado indício de ato de alienação parental, a requerimento ou de ofício, em qualquer momento processual, em ação autônoma ou incidentalmente, o processo terá tramitação prioritária, e o juiz determinará, com urgência, ouvido o Ministério Público, as medidas provisórias necessárias para preservação da integridade psicológica da criança ou do adolescente, inclusive para assegurar sua convivência com genitor ou viabilizar a efetiva reaproximação entre ambos, se for o caso.

Parágrafo único. Assegurar-se-á à criança ou adolescente e ao genitor garantia mínima de visitação assistida, ressalvados os casos em que há iminente risco de prejuízo à integridade física ou psicológica da criança ou do adolescente, atestado por profissional eventualmente designado pelo juiz para acompanhamento das visitas.

Art. $5^{\circ}$ Havendo indício da prática de ato de alienação parental, em ação autônoma ou incidental, o juiz, se necessário, determinará perícia psicológica ou biopsicossocial. 
$\S 1^{\circ}$ O laudo pericial terá base em ampla avaliação psicológica ou biopsicossocial, conforme o caso, compreendendo, inclusive, entrevista pessoal com as partes, exame de documentos dos autos, histórico do relacionamento do casal e da separação, cronologia de incidentes, avaliação da personalidade dos envolvidos e exame da forma como a criança ou adolescente se manifesta acerca de eventual acusação contra genitor.

$\S 2^{\circ}$ A perícia será realizada por profissional ou equipe multidisciplinar habilitados, exigido, em qualquer caso, aptidão comprovada por histórico profissional ou acadêmico para diagnosticar atos de alienação parental.

$\S 3^{0}$ O perito ou equipe multidisciplinar designada para verificar a ocorrência de alienação parental terá prazo de 90 (noventa) dias para apresentação do laudo, prorrogável exclusivamente por autorização judicial baseada em justificativa circunstanciada.

Art. $6^{\circ}$ Caracterizados atos típicos de alienação parental ou qualquer conduta que dificulte a convivência de criança ou adolescente com genitor, em ação autônoma ou incidental, o juiz poderá, cumulativamente ou não, sem prejuízo da decorrente responsabilidade civil ou criminal e da ampla utilização de instrumentos processuais aptos a inibir ou atenuar seus efeitos, segundo a gravidade do caso:

I - declarar a ocorrência de alienação parental e advertir o alienador;

II - ampliar o regime de convivência familiar em favor do genitor alienado;

III - estipular multa ao alienador;

IV - determinar acompanhamento psicológico e/ou biopsicossocial;

V - determinar a alteração da guarda para guarda compartilhada ou sua inversão;

VI - determinar a fixação cautelar do domicílio da criança ou adolescente;

VII - declarar a suspensão da autoridade parental.

Parágrafo único. Caracterizado mudança abusiva de endereço, inviabilização ou obstrução à convivência familiar, o juiz também poderá inverter a obrigação de levar para ou retirar a criança ou adolescente da residência do genitor, por ocasião das alternâncias dos períodos de convivência familiar.

Art. $7^{\circ}$ A atribuição ou alteração da guarda dar-se-á por preferência ao genitor que viabiliza a efetiva convivência da criança ou adolescente com o outro genitor nas hipóteses em que seja inviável a guarda compartilhada.

Art. $8^{\circ}$ A alteração de domicílio da criança ou adolescente é irrelevante para a determinação da competência relacionada às ações fundadas em direito de convivência familiar, salvo se decorrente de consenso entre os genitores ou de decisão judicial.

Art. $9^{\circ}$ (VETADO)

Art. 10. (VETADO)

Art. 11. Esta Lei entra em vigor na data de sua publicação.

Brasília, 26 de agosto de 2010; $189^{\circ}$ da Independência e $122^{\circ}$ da República.

LUIZ INÁCIO LULA DASILVA

Luiz Paulo Teles Ferreira Barreto

Paulo de Tarso Vannuchi 


\section{ANEXO B - Matéria sobre falsa alegação de abuso sexual}

\section{Mãe teria molestado filha para incriminar o pai no Espírito Santo}

Plantão | Publicada em 22/07/2011 às $09 \mathrm{~h} 16 \mathrm{~m}$

Gazeta Online

VITÓRIA - Na guerra pela guarda de uma criança de 3 anos, uma mãe é suspeita de molestar a própria filha na tentativa de acusar o ex-marido pelo crime de estupro.

A denúncia foi feita pelo pai da menina, um empresário de 36 anos, depois que ouviu da própria filha ela relatar como a mãe a molestava.

- Ao passar na frente do hospital, minha filha disse que estava com a região genital doendo, devido ao que a mãe fazia com ela - relatou o pai.

Segundo ele, o casal está separado há dois anos e meio e, atualmente, possui a guarda compartilhada da menina.

- Entrei na Justiça para obter a guarda definitiva. Desde então, a mãe da menina já até fugiu com ela para o Rio para evitar isso - lamentou o empresário.

Para o empresário, o objetivo era simular que ele estuprava a filha para que a mãe dela usasse isso na ação judicial pela guarda da criança.

O caso foi registrado na Delegacia de Proteção à Criança e ao Adolescente (DPCA). Para o delegado Marcelo Nolasco, o caso é grave.

- A criança é bem articulada e espontânea, inicialmente, descartamos a manipulação por parte do pai. Relata com detalhes os abusos da mãe. A suspeita será investigada e intimada para depor na delegacia afirmou Nolasco.

Uma médica que esteve com a criança, antes do caso chegar ao conhecimento do pai, se disponibilizou a prestar depoimento confirmando a versão apresentada pela menina.

Leia mais sobre esse assunto em http://oglobo.globo.com/cidades/mat/2011/07/22/mae-teria-molestado-filhapara-incriminar-pai-no-espirito-santo-924958967.asp\#ixzz1SrUTYSiy

(C) 1996 - 2011. Todos os direitos reservados a Infoglobo Comunicação e Participações S.A. 


\section{ANEXO C - Matéria sobre indenização por falsa alegação de abuso sexual}

Parte inferior do formulário

Prefeitura confunde alergia com abuso sexual, manda menor para abrigo e é condenada a indenizar pais $08 / 11 / 2010$

UOL Notícias - Cotidiano

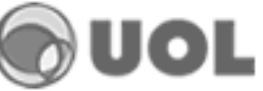

$08 / 11 / 2010-15 h 50$

\section{Prefeitura confunde alergia com abuso sexual, manda menor para abrigo e é condenada a indenizar pais}

Especial para o UOL Notícias

Em São Paulo

O Tribunal de Justiça de São Paulo condenou a Prefeitura de São José dos Campos (97 km de São Paulo) a

indenizar em R 70 mil os pais acusados injustamente de abuso sexual contra a filha. O caso envolveu a ação de integrantes do Conselho Tutelar, que confundiram alergia com estupro, separaram a menina da família e a mandaram para um abrigo de menores, sem que os acusados fossem ouvidos.

O equívoco sobre o suposto abuso aconteceu em março de 2000 , quando a criança tinha quatro anos. O caso só foi solucionado agora, mais de dez anos depois, pelo Tribunal de Justiça. A prefeitura ainda pode recorrer aos tribunais superiores em Brasília.

A confusão só foi desfeita com a intervenção do Ministério Público, que decidiu ouvir os pais e o médico que cuidava da criança. Os primeiros negaram qualquer abuso. O segundo esclareceu que a menina sofria de alergia. O médico contou que havia um quadro de irritação vaginal e que ele mesmo havia informado a escola sobre a situação.

Diante das provas, o promotor de justiça pediu à Justiça que determinasse a devolução da menina a seus pais. Inconformada com a atitude do Conselho Tutelar, a família ingressou com ação de indenização. Pediu R\$ 70 mil pelo dano moral sofrido com a separação temporária da criança e a sua internação em um abrigo.

A Justiça de São José dos Campos aceitou em parte o pedido da família e mandou a Prefeitura pagar indenização de R\$ 30 mil. O caso foi parar no Tribunal de Justiça de São Paulo. A Prefeitura pediu sua absolvição, e os pais, o aumento da indenização.

A prefeitura alegou que o Conselho Tutelar agiu de acordo com a lei. Segundo a defesa do município, quando se trata de suposto abuso sexual contra criança, cometido pelo seu pai, é dever da autoridade retirar a criança do convívio familiar. $\mathrm{O}$ objetivo seria evitar danos e constrangimentos maiores à menina caso as denúncias fossem confirmadas.

“É melhor assumir os riscos do que ignorar a possibilidade da menor continuar sofrendo abusos, e, se a denúncia não restou comprovada, o Conselho Tutelar não pode ser condenado por cumprir seu dever legal", sustentou a Procuradoria do Município.

O casal argumentou que a atitude dos conselheiros foi ilícita e que o valor da indenização deve ser aumentado pela dor e sofrimento experimentado por eles e pela criança.

O Tribunal condenou a forma como o Conselho Tutelar conduziu a investigação do suposto abuso sexual, que depois foi comprovado como inexistente. A câmara que julgou o recurso entendeu que o valor fixado pelo juiz de São José dos Campos foi muito baixo para compensar o sofrimento das vítimas do abuso e determinou que a indenização seria de R\$ 70 mil. 